FACULDADE DE FILOSOFIA, LETRAS E CIÊNCIAS HUMANAS DEPARTAMENTO DE LETRAS CLÁSSICAS E VERNÁCULAS

\title{
CRISTIANE RODRIGUES DE SOUZA
}

\section{Remate de males: a música de poemas amorosos de Mário de Andrade}


FACULDADE DE FILOSOFIA, LETRAS E CIÊNCIAS HUMANAS DEPARTAMENTO DE LETRAS CLÁSSICAS E VERNÁCULAS

\title{
Remate de males: a música de poemas amorosos de Mário de Andrade
}

\author{
CRISTIANE RODRIGUES DE SOUZA
}

Tese apresentada ao Departamento de Letras Clássicas e Vernáculas da Faculdade de Filosofia, Letras e Ciências Humanas da Universidade de São Paulo, para obtenção do título de Doutora em Literatura.

Orientador: Prof. Dr. Alcides Celso de Oliveira Villaça. 
Para Aparecido, Mariene, Gustavo, Mariangela, Matheus e Arthur. 


\section{AGRADECIMENTOS}

Ao professor Alcides Villaça, pela maneira acolhedora e amiga com que me recebeu entre seus orientandos, partilhando comigo sua forma sensível e apurada de ler poesia, a quem devo muito de minha formação crítica. À professora Laura Beatriz Fonseca de Almeida, fundamental nos anos iniciais de aprendizado, pela amizade e incentivos constantes e pelo exemplo a ser seguido. À professora Telê Porto Ancona Lopez, que gentilmente colaborou com a pesquisa por meio de conversas no IEB, de leituras atentas do texto e de ótimas sugestões, além da participação no exame de qualificação. Ao professor Murilo Marcondes de Moura, presença amiga e atenciosa, pela leitura atenta e sugestões feitas durante a qualificação. À professora Raquel Illescas Bueno, pelas conversas sobre literatura e pela amizade. Aos professores e funcionários da FFLCH-USP e do IEB, pelo suporte. À FAPESP, pelo apoio. Aos colegas de orientação Alexandre Shiguehara, André Luis Rodrigues, Ieda Lebensztayn, Maria Claudete de S. Oliveira, Mário Alex Rosa, Maria Rejane Tito Araújo, além de Ana Luíza Reis Bedê e tantos outros que tão bem me receberam. Ao professor Ivan Vilela, músico que admiro, pelos ensinamentos e amizade. Ao Maurício de Carvalho Teixeira, pelas conversas amigas sobre poesia e música e pelas excelentes sugestões. À Carolina Donega Bernardes e Rodrigo Marques de Oliveira, amigos antigos e presentes, pelo apoio carinhoso. À Erika Cristina Romero, pela amizade atenciosa. À Jakeline Fernandes Cunha, amiga e companheira de estudos, pelas discussões sobre a pesquisa. Ao Laerte Asnis e à Valéria Peres, artistas especiais e amigos fundamentais, por sempre indicarem caminhos. A todos os outros amigos, indispensáveis e queridos. Aos familiares, pelo carinho. À Maria Cruz Zeppone, minha avó, pelo exemplo e incentivo. Aos meus pais, Aparecido e Mariene, pelo apoio imprescindível e pelo olhar confiante que sempre depositam em mim. Aos meus irmãos queridos, Gustavo e Mariangela, presentes sempre. À Naiene Pimentel, pela amizade e torcida. Aos meus filhos Matheus e Arthur, pela compreensão e presença. 
As obras de arte são de uma infinita solidão [...]. Só o amor as pode compreender e manter e mostrar-se justo com elas.

Rainer Maria Rilke

Arte da crítica: [...] o esforço apaixonado de amar e compreender. Mário de Andrade 


\title{
Resumo
}

A música percorre a obra de Mário de Andrade como matriz de seu fazer poético. Harmonizando as diferentes faces do poeta arlequinal, sua face musical aparece em Paulicéia desvairada (1922) e em Losango cáqui (1926), assim como nos versos de Clã do jabuti (1927), permanecendo, ainda, em Remate de males (1930) e nos volumes de poesia posteriores. O estudo detido de três grupos de poemas do livro de 1930 Tempo da Maria (1926), Poemas da negra (1929) e Poemas da amiga (1920-1930)-, realizado nesta tese, permite perceber em que medida a música e a retomada de formas populares, como a estrutura das Danças Dramáticas, moldam os poemas de Mário de Andrade, em que dilemas amorosos do eu lírico são encenados.

Palavras-chave: Mário de Andrade, poesia, Remate de males, música, lírica amorosa.

\begin{abstract}
The music is the matrix of the poetic work of Mário de Andrade. Harmonizing the different faces of the multiple poet, his "musical face" can be seen in the books Paulicéia desvairada (1922), Losango cáqui (1926) and Clã do jabuti (1927), as well as in the verses of Remate de males (1930), and in the posterior works of the author. A detailed study of poems that are organized in tree groups of Remate de males - Tempo da Maria (1926), Poemas da negra (1929) e Poemas da amiga (1920-1930) -, accomplished by this thesis, allows us to notice how the music and the popular forms, as the structure of the "Danças Dramáticas", mould the poems of Mário de Andrade, in which appears amorous dilemmas.
\end{abstract}

Keywords: Mário de Andrade, poetry, Remate de males, music, love poetry. 


\section{Sumário}

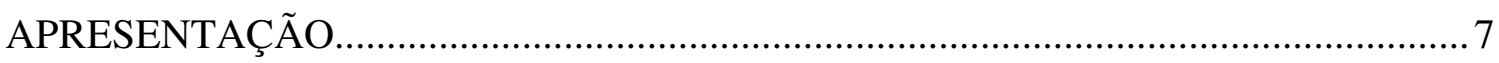

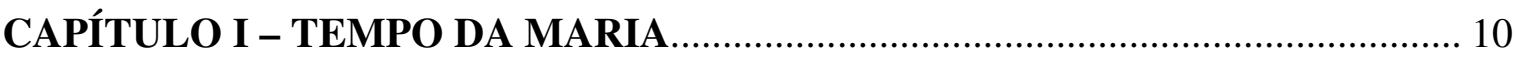

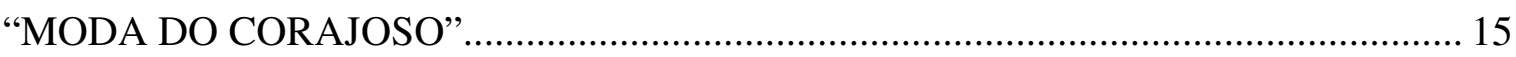

DOIS POEMAS DE “TEMPO DA MARIA”................................................................ 40

“Amar sem ser amado, ora pinhões!"............................................................................. 41

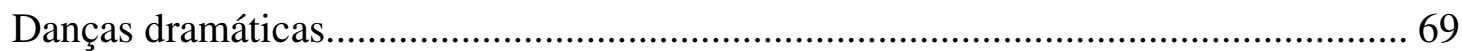

"Louvação da tarde"..................................................................................... 75

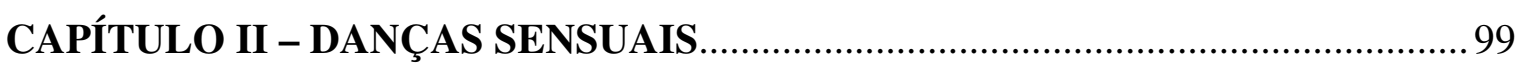

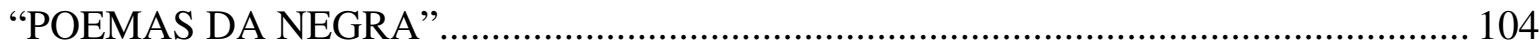

CAPÍTULO III - MOMENTOS AMOROSOS E MUSICAIS.................................... 128

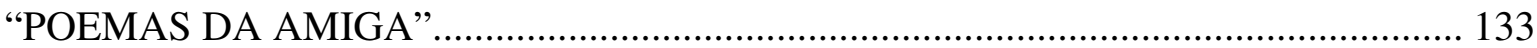

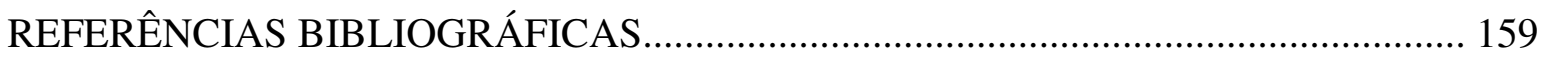




\section{Apresentação}

O desejo de Mário de Andrade em conhecer as notas profundas da expressão musical de seu país que, ditando também o compasso de seu ser fragmentado ${ }^{1}$, são recriadas em versos e estrofes eruditos, constrói uma das faces do poeta: a face musical que, tendo sido delineada em Paulicéia desvairada (1922) e em Losango cáqui (1926), ganhando contornos expressivos em Clã do jabuti (1927), permanece, ainda, no livro de poemas de 1930, Remate de males (1930), assim como nos livros de poesia da fase madura do autor. O ouvido atento e sensível do poeta-pesquisador apreende, em Paulicéia, a música áspera da cidade que se moderniza e, após experimentar o sabor coloquial de Losango cáqui, colhe tons e melodias típicos do Brasil - modas, acalantos, toadas, rondós, romances, sambinhas - no livro de 1927, partindo, em Remate de males, em busca de uma outra sonoridade, de sua "música interior" 2, multifacetada e complexa. Dessa forma, a face musical de Mário de Andrade percorre a sua obra como fio condutor que harmoniza - de forma semelhante a uma combinação simultânea de "sons" equilibrados de forma tensa - as outras faces do poeta arlequinal, destacadas pela crítica $^{3}$.

A fim de compreendermos a face musical do modernista, buscamos, em Remate de males, a música dos versos construída por meio do ritmo singular dos poemas marioandradinos que, ao lado da plasticidade sonora dos fonemas, dá forma à música feita com palavras. Como afirma José Miguel Wisnik, a "poética musical mário-andradina pratica uma autêntica e toscamente sofisticada harmonia de timbres [...], potenciando a capacidade percussiva das oclusivas, o brilho atritivo das fricativas e vibrantes aliteradas [...] e acentuando o traço semi-musical que resulta da mistura lexical" " . Além disso, há momentos em que o poeta se inspira em formas musicais, como podemos conferir por meio de poemas de Remate de males, como "Moda do corajoso", em que o caráter improvisatório típico da moda é resgatado, invocando a maneira popular de se contar casos, ou "Louvação da tarde",

\footnotetext{
${ }^{1}$ Como afirma Lafetá, citando Rosenfeld, "a busca da identidade nacional [...] liga-se 'ao problema mais íntimo da descoberta da própria identidade”” (LAFETÁ, J. L. Figuração da intimidade. São Paulo: Martins Fontes, 1986, p 8).

2 BASTIDE, R. Poetas do Brasil. São Paulo: Edusp; Duas Cidades, 1997, p 77.

${ }^{3}$ O poeta folclórico do Clã do jabuti, o poeta do cotidiano de Paulicéia desvairada e Losango cáqui e o poeta de si mesmo de Remate de males, bem como o poeta eu mais o mundo d'A costela do Grã Cão e do Livro Azul, e o poeta político de $O$ carro da miséria, Lira paulistana e Café, faces do poeta múltiplo, são apontados por Antonio Candido e por Lafetá (LAFETÁ, J. L. Figuração da intimidade. São Paulo: Martins Fontes, 1986, p 7)

4 WISNIK, J. M. Dança dramática. (Poesia/ música brasileira) Tese de doutoramento apresentada ao Departamento de Línguas Orientais e Teoria Literária. FFLCH - USP. São Paulo, 1979, p 34-35.
} 
recriação do canto laudatório. A face musical de Mário de Andrade também se deixa perceber, no livro de 1930, por meio da organização de seus grupos de poemas que recupera a estrutura das Danças Dramáticas brasileiras, bailados tradicionais do povo. Da mesma maneira, a assimilação, nos versos do poeta, de técnicas como o tema e a variação, entre outros, são recursos musicais incorporados à estrutura de seus poemas.

Como nos lembra Octavio Paz, "no fundo de todo fenômeno verbal há um ritmo, [...] [sendo] a criação poética [...] a utilização voluntária do ritmo como agente de sedução" 5 . No entanto, os versos de Mário de Andrade ultrapassam o ritmo poético de que fala o estudioso, atingindo o fundo obscuro da música. Como afirma Wisnik, "a música percorre a obra literária de Mário de Andrade, de ponta a ponta, [...] como mito interno, horizonte implícito, às vezes explícito, mas sempre incontornável, da palavra literária" 6 .

Em Remate de Males (1930), objeto de estudo desta tese, o eu lírico se reconhece e se assume múltiplo, complexo e plural, mas pleno do desejo de compreender a si mesmo e ao seu país por meio da arte. A busca pela singularidade brasileira ultrapassa a fronteira que separa o mundo erudito do mundo popular, já que a riqueza melódica da nossa poesia, cantada nos versos de Clã do Jabuti, alcança uma complexidade, ainda maior, na face múltipla do eu poético que se reconhece voz plural - "Eu sou trezentos, sou trezentos-ecincoenta/ Mas um dia afinal eu toparei comigo..." -, revelando sentir, no próprio eu, a diversidade encontrada, antes, na metrópole paulista e no interior do Brasil. Se nos primeiros volumes de poemas, o poeta procurou, em sons urbanos, a música dissonante da cidade e, nos tons populares e folclóricos, a diversidade da música brasileira, parte, em Remate de males, em busca da música contraditória de seu próprio ser plural. O livro de 1930 revela-se, portanto, como afirma Lafetá, "síntese das direções anteriores e busca de novos rumos, balanço e fecho da primeira fase modernista" 7 .

No volume de 1930, como lembra o estudioso, Mário de Andrade “[abandona] o nacionalismo exterior e pitoresco dos anos 1920 e [mergulha] em si mesmo, numa sondagem

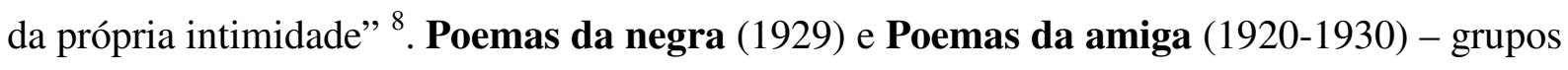
de poemas de Remate de males, estudados no segundo e no terceiro capítulos da tese - são, no

\footnotetext{
${ }^{5}$ PAZ, O. O arco e a lira. Trad. Olga Savary. Rio de Janeiro: Nova Fronteira, 1982, p 63-64.

${ }^{6}$ WISNIK, J. M. Mário e a música. Revista da Biblioteca Mário de Andrade. São Paulo, v. 50, janeiro-dezembro de $1992, \mathrm{p} 8$.

${ }^{7}$ LAFETÁ, J. L. Figuração da intimidade. São Paulo: Martins Fontes, 1986, p 14.

${ }^{8}$ LAFETÁ, J. L. A dimensão da noite. Org. de Antonio Arnoni Prado. São Paulo: Duas Cidades, 2004, p 223.
} 
dizer do crítico, "escritos como que em surdina, discretos e suaves" 9 . Neles, a intensidade gritada de Paulicéia e a música explícita do Clã sofrem um decrescendo, atingindo o pianíssimo, quase o silêncio reflexivo, pausa preparatória de um novo recomeço: remate musical que prenuncia, como nos ensina Lafetá, "a produção modernista madura e equilibrada dos anos trinta" ${ }^{10}$. A música desses poemas de Mário de Andrade, espraiando-se em um maior número de versos longos, num tom comedido, insinua-se, portanto, de forma implícita, tornando-se, o eu lírico, "o bojo vazio do violão" cantos encontrados pelo poeta em suas andanças por São Paulo e pelo país.

No entanto, antes do momento de entrega à música de seu eu, o poeta retoma, em Remate de males, a música singular de Clã do jabuti, por meio dos versos do grupo Tempo da Maria (1926), estudado no primeiro capítulo da tese, resgatando a expressão popular como forma de se preparar para o mergulho íntimo em seu próprio ser.

Os três grupos de poemas do livro de 1930 eleitos para estudo - Tempo da Maria, Poemas da negra e Poemas da amiga - revelam a música por meio de seus versos, ao recuperarem, uns de forma explícita e outros de forma mais diluída, a estrutura das Danças Dramáticas populares, encenando, por meio de sua retomada, os dilemas de amor do poeta. A leitura desses versos, portanto, nos permite perceber a expressão do sentimento amoroso em Remate de males. Além disso, ao darmos ênfase ao diálogo entre o fazer poético e a sensibilidade musical de Mário de Andrade, procurando apontar em que medida a música se deixa perceber por meio de seus versos, pretendemos compreender e avaliar em profundidade a configuração do sujeito lírico.

\footnotetext{
${ }^{9}$ Ibidem, p 223.

${ }^{10}$ LAFETÁ, J. L. Figuração da intimidade. São Paulo: Martins Fontes, 1986, p 28.

${ }^{11}$ Verso do poema "A adivinha", de Remate de males.
} 


\section{TEMPO DA MARIA}

No grupo de poemas Tempo da Maria, de Remate de males (1930), após ter retomado a música dissonante dos versos de Paulicéia desvairada (1922), por meio do poema "Danças", do mesmo livro, escrito no estilo fragmentado e combativo da vanguarda ${ }^{1}$, Mário de Andrade resgata os tons musicais populares que formam a musicalidade singular de Clã do jabuti (1927), como se estivesse a mastigar novamente ritmos já experimentados, realizando, assim, um balanço - remate - poético do primeiro momento modernista, como nos ensina Lafetá ${ }^{2}$.

Formado por sete poemas numerados, Tempo da Maria possui composições poéticas que invocam a forma musical da moda de viola - "Moda do corajoso" -, reescrevem versos populares - "Amar sem ser amado, ora pinhões!" e "Maria" - e retomam lendas indígenas "Cantiga do ai" e "Lenda das mulheres de peito chato" -, trabalhando a sonoridade da fala e da música do povo brasileiro.

Como nos lembra Diléa Zanotto Manfio, Mário de Andrade pretendia publicar um livro intitulado Ciclo de Maria, seguindo a estrutura de Vita nuova, de Dante Alighieri, em que, assim como o poeta italiano, louvaria a musa inacessível. Não tendo dado certo o projeto, os poemas foram publicados em Remate de males, formando Tempo da Maria. Nesse grupo de poemas, Mário de Andrade resgata a musicalidade brasileira para cantar seu amor pela dona sublime, de forma semelhante ao louvor de Dante que, por meio de baladas, canções e sonetos, canta o amor por Beatriz. Diléa esclarece-nos, ainda, que os poemas, de acordo com Rubens Borba de Moraes, em 7 Cartas, foram inspirados pelo amor platônico de Mário pela filha de D. Olívia Guedes Penteado, Carolina da Silva Telles ${ }^{3}$. O amor proibido pela dona casada é cantado em Tempo da Maria, em que o poeta realiza, por meio de seus versos, a sublimação de um desejo recalcado.

Rastreando as leituras de Mário de Andrade, Telê Ancona Lopez aponta o ano de 1923 como a data provável do início da ligação do escritor com a psicanálise ${ }^{4}$. O interesse de Mário pelos textos de Freud transparece nas anotações marginais feitas em alguns livros da biblioteca do estudioso, como Trois éssais sur la théorie de la sexualité, em que destaca, por

\footnotetext{
${ }^{1}$ LAFETÁ, J.L. A poesia de Mário de Andrade. In: A dimensão da noite (Organização de Antonio Arnoni Prado). São Paulo: Duas Cidades; Ed 34, 2004, p 330.

2 LAFETÁ, J. L. Figuração da Intimidade. São Paulo: Martins Fontes, 1986, p 28.

${ }^{3}$ ANDRADE, M. Poesias completas. Edição crítica de Diléa Zanotto Manfio. Belo Horizonte: Villa Rica, 1993, p 509.

${ }^{4}$ LOPEZ, T. P. A. Mário de Andrade: ramais e caminhos. São Paulo: Duas Cidades, 1972, p 105.
} 
meio de numerais romanos ("IV" e "V"), os capítulos "Refoulement" e "Sublimation", como demonstra Nites Therezinha Feres, em seu livro Leituras em francês de Mário de Andrade $e^{5}$

Em Trois éssais sur la théorie de la sexualité, Freud reflete sobre as conseqüências causadas pela repressão ("refoulement") dos instintos sexuais que, não eliminados, obtém "descarga" ao se transformarem em sintomas de pacientes histéricos:

Entre a pressão do instinto e seu antagonismo à sexualidade, a doença lhe oferece um caminho de fuga. Ela não resolve seu conflito, mas busca evadilo, transformando os impulsos libidinosos em sintomas ${ }^{6}$.

Uma alternativa para a descarga dos impulsos sexuais recalcados é o processo de sublimação. Por meio dele, de acordo com Freud, excitações sexuais excessivamente fortes encontram uma saída e uso no campo artístico ${ }^{7}$.

Como nos ensina Telê, o termo "refoulement", ligado ao sentido de "sublimation", dá origem à expressão "seqüestro", "usada [por Mário de Andrade] para designar o mesmo fenômeno e ainda outros na literatura erudita e popular, na arte e na observação do cotidiano" $"$.

Mário de Andrade chama de "seqüestro da dona ausente" a repressão e a sublimação sexual entre os portugueses navegantes que, ao deixarem seu país, sentindo a dor causada pela ausência da mulher branca, procuram superar o sofrimento por meio de cantigas e versos, ao “disfarçar o martírio nas imagens e nos símbolos da poesia”, como afirma Mário de Andrade, em texto publicado na Revista Atlântico, em $1943^{9}$. De acordo com o estudioso, herdando o complexo marítimo dos portugueses, os brasileiros, sofrendo também nas novas terras a ausência de mulheres brancas, seqüestram o desejo em versos.

Procurando conhecer a fundo o sentimento amoroso do povo brasileiro, um dos traços formadores de nosso caráter, Mário vasculha textos de literatura popular que tratam do tema do amor, no intuito de compreender em que medida o seqüestro, herdado dos portugueses, um

\footnotetext{
${ }^{5}$ NITES, T. F. Leituras em francês de Mário de Andrade. São Paulo: Publicação do IEB,1969, p 77-8.

${ }^{6}$ FREUD, S. Três ensaios sobre a teoria da sexualidade. Pequena coleção das obras de Freud. Rio de Janeiro: Imago, 1973, p 57.

${ }^{7}$ Ibidem, p 135.

${ }^{8}$ LOPEZ, T. P. A. Op. cit., p 106.

${ }^{9}$ ANDRADE, M. A dona ausente. Atlântico: revista luso-brasileira, Rio de Janeiro, n. 3, 1943, p 9.
} 
povo de navegantes, aparece em nossa literatura transformado por meio de constantes históricas e sociais, como lembra Telê ${ }^{10}$.

Em sua Dissertação de Mestrado, Ricardo Souza de Carvalho, orientado por Telê Ancona Lopez, estuda o processo de criação do texto "O seqüiestro da dona ausente", por meio dos manuscritos de Mário de Andrade e de outras fontes. De acordo com Ricardo, empenhado na pesquisa do complexo da dona distante, Mário anuncia, no verso da folha de rosto de Música, doce música (1934), o lançamento futuro de suas reflexões em forma de livro $^{11}$. No entanto, como nos lembra o estudioso, os resultados da pesquisa foram publicados apenas em forma de resumo não assinado de uma conferência proferida na Sociedade de Etnografia e Folclore, em 1937; como trecho de conferência realizada em Belo Horizonte, na revista Mensagem, em 1939; e em artigo da revista luso-brasileira Atlântico, em 1943, procurando "patentear" a idéia, como Mário afirma a Moacir Wernek de Castro, em carta de 28 de janeiro de 1944 - "É que eu ainda não tirara patente de invenção de um assunto lusobrasileiro [o seqüestro da dona ausente] que eu descobri, de que tiro muita vaidade, que tenho estudado quando e como posso [...] sobre o qual ainda eu não escrevera coisa alguma" 12 .

Encontrado em textos da crítica como “A poesia em 1930”, publicado por Mário de Andrade, em 1931, na Revista Nova ${ }^{13}$ e no livro Aspectos da Literatura Brasileira, em que o estudioso trata, entre outras coisas, de dois seqüestros presentes em Alguma poesia, livro de poemas de Drummond - "dois seqüestros tem no livro, pelo menos dois, que me parecem muito curiosos: o sexual e o que chamarei 'da vida besta", 14-, e em "Amor e medo", ensaio em que Mário estuda diferentes formas do "medo do amor" dos românticos brasileiros, demonstrando "o sambinha de seqüestro que o amor e medo saracoteou na excessiva mocidade dos nossos maiores poetas românticos" 15, o "seqüestro" permeia também os poemas de Mário de Andrade, especialmente Tempo da Maria, em que o tema amoroso da dona ausente, oriundo da tradição popular, é cantado em forma de moda, cantiga, lenda e louvação. Em seus versos, o poeta atualiza um tema que se tradicionalizou através dos séculos

\footnotetext{
${ }^{10}$ Cf. LOPEZ, T. P. A. Mariodeandradeando. São Paulo: Hucitec, 1996, p 118- 122.

${ }^{11}$ CARVALHO, R. S. Edição genética d'o seqüestro da dona ausente de Mário de Andrade. Dissertação de Mestrado apresentada ao Departamento de Letras Clássicas e Vernáculas. FFLCH - USP. São Paulo, 2001, p 2324.

${ }^{12}$ Ibidem, p 28-29.

${ }^{13}$ Revista Nova, a. 1. Rio de janeiro, 15 mar. 1931, p 111.

${ }^{14}$ ANDRADE, M. A poesia em 1930. In: Aspectos da Literatura Brasileira. Belo Horizonte: Itatiaia, 2002 , p 45.

${ }^{15}$ ANDRADE, M. Amor e medo. In: Aspectos da Literatura Brasileira. Belo Horizonte: Itatiaia, 2002, p 251.
} 
por ser "duma beleza perfeitamente pura e equilibrada, [sendo] [...] sem dúvida um dos mais belos, mais elevados, mais líricos e mais permanentes do folclore universal" ${ }^{16}$.

\section{Moda do corajoso}

Maria dos meus pecados, Maria, viola de amor...

Já sei que não tem propósito Gostar de donas casadas, Mas quem que pode com o peito!

Amar não é desrespeito, Meu amor terá seu fim. Maria há-de ter um fim.

Quem sofre sou eu, que importa Pros outros meu sofrimento? Já estou curando a ferida. Se dando tempo pro tempo Toda paixão é esquecida. Maria será esquecida.

Que bonita que ela é!... Não Me esqueço dela um momento! Porém não dou cinco meses, Acabarão as fraquezas E a paixão será arquivada. Maria será arquivada.

Por enquanto isso é impossível. $\mathrm{O}$ meu corpo encasquetou De não gostar senão de uma... Pois, pra não fazer feiúra, Meu espírito sublima $\mathrm{O}$ fogo devorador. Faz da paixão uma prima, Faz do desejo um bordão, E encabulado ponteia A malvadeza do amor.

Maria, viola de amor!...

Em "Moda do corajoso", poema de abertura de Tempo da Maria, usando a forma da moda e recuperando o tom e o ritmo dos cantadores populares, o eu lírico anuncia o seqüestro do desejo latente que, transformado em música - canto poético ponteado na viola de amor -, percorre os versos. Nesse grupo, o poeta canta o desejo despertado pela mulher e, ao mesmo

${ }^{16}$ ANDRADE, M. Dona Ausente (Manuscrito). In: CARVALHO, op. cit., p 51-2. 
tempo, a impossibilidade de realizá-lo, mantendo-se, portanto, em momento de suspensão, em compasso de espera, em que, no entanto, ainda não pode esquecer o desejo amoroso.

Desejar o amor impossível é uma das contradições que percorrem "Moda do corajoso", poema que deixa entrever, por meio da coexistência tensa de contrários, a poética arlequinal do escritor moderno. Marcada pelo tema da fragmentação, a obra de Mário de Andrade revela, por meio da sobreposição de opostos, um poeta preocupado em resgatar traços de seu país, formado por um mosaico de diferentes culturas. Em busca da identidade brasileira, assim como de sua própria identidade, o poeta incorpora a seus versos o tom típico do tocador de violas, fazendo uso da forma musical da Moda.

Como lembra Mário de Andrade, a Moda é acompanhada freqüentemente por viola ${ }^{17}$. Instrumento muito utilizado em Portugal, trazido ao Brasil pelos jesuítas na época colonial, a viola manteve, em terras brasileiras, seu caráter popular, tendo sido amplamente difundida pelo país ${ }^{18}$. No entanto, uma viola de amor, e não uma viola popular, acompanha a "Moda do corajoso". Instrumento europeu erudito, muito difundido nos séculos XVII e XVIII, principalmente na Áustria, na Alemanha e na Itália, utilizado em obras de Scarlatti, J. S. Bach, Vivaldi e Haydn, entre outros, a viola de amor é tangida pelo cantador brasileiro, que tira dela os sons que acompanham seu canto moreno. A coexistência do canto popular e do instrumento erudito europeu, em "Moda do corajoso", lembra o "tupi [que tange] o alaúde", de Paulicéia desvairada, verso que sintetiza a contradição sentida pelo poeta no seu país e em si mesmo, fissura que marca sua obra.

Telê Ancona Lopez aponta a possível origem do verso-chave de Paulicéia desvairada - "sou um tupi tangendo um alaúde!" - em Alfred de Musset.

Do passado, "lição para se meditar", isto é, no reconhecimento da parcela européia da cultura do Brasil, processado por novos olhos, saem pois o trovador e o alaúde que, em "La nuite de mai" de "Poésies Nouvelles" [de Alfred de Musset], recebem um destino dentro do romantismo. Ao longo desse poema, a musa romântica indica a tradição medieval como garantia da nacionalidade e exorta o poeta a perseguir sua identidade e sua definição, ao reiterar o apelo "Poéte, prends ton luth, [...]" 19 .

\footnotetext{
${ }^{17}$ ANDRADE, M. Dicionário musical brasileiro. Coordenação de Oneyda Alvarenga, 1982-84, e de Flávia Camargo Toni, 1984-89. Belo Horizonte: Itatiaia, 1999, p 342 (O Dicionário musical brasileiro, editado postumamente, é formado por textos redigidos por Mário de Andrade, por trechos baseados na bibliografia de apoio ou na bibliografia indicada pelo estudioso, assim como por textos redigidos por Oneyda Alvarenga. Neste trabalho, indico a autoria de Mário de Andrade, no corpo do texto, sempre que cito trecho redigido por ele, não indicando autoria específica quando faço uso de trechos não escritos pelo modernista).

${ }^{18}$ CORREA, R. A arte de pontear viola. Brasília; Curitiba: Ed Autor, 2000, p 21, 24.

${ }^{19}$ LOPEZ, T. P. A. A biblioteca de Mário de Andrade: seara e celeiro da criação. ZULAR, R. Criação em processo. Ensaios de crítica genética. São Paulo: Iluminuras, 2002, p 68-9.
} 
Estudando Gonçalves Dias, "que eleva a figura do trovador e do alaúde”, Mário de Andrade possivelmente descobriu no poeta brasileiro a filiação em Musset, como afirma Telê - "arriscamo-nos, assim, a ligar Gonçalves Dias ao Musset de 'La nuit de mai' e conseqüentemente ao nosso Mário" 20.

Gonçalves Dias [...] em "Canção", [...] se reparte em três caminhos, cada qual depositado em um instrumento musical. Então, à harpa confia a poesia religiosa; à lira, os suspiros pela amada, e ao alaúde, [...] recusa as "trovas de amores" que caracterizavam os "antigos trovadores" (v. 1-16). Constitui-se em um novo trovador, fiel à lição da musa de "La nuit de mai", ao entregar ao alaúde uma missão solene, nacional, anunciada apenas nos versos finais reservados pela leitura do poeta modernista:

Votei assim ao meu Deus

A minha harpa religiosa,

A ti a lyra mimosa,

O grave alaúde aos meus! $!^{21}$

Se em Paulicéia desvairada, inspirando-se em Musset e em Gonçalves Dias, Mário de Andrade, como o poeta maranhense, dedica o alaúde a um projeto estético brasileiro, em "Moda do corajoso", apesar de aproximar, por meio da coexistência do canto popular e do instrumento erudito, a viola de amor ao alaúde do verso de Paulicéia desvairada, mostrandose consciente de sua mestiçagem e em busca de uma definição do nosso povo, não nega ao instrumento as "trovas de amores", como faz Gonçalves Dias, pois o instrumento de cordas é, como a lira do poeta romântico, dedicado também à amada - Maria. Dessa forma, acompanhando o canto do poeta-trovador que dedilha seu amor e, ao mesmo tempo, resgata a sua identidade nacional, a viola de amor é o alaúde reinventado.

Os versos de Tempo da Maria mostram o grande dilema que acompanha a obra de Mário de Andrade. Dividido entre a necessidade da utilização social da obra de arte e a necessidade do Belo (da arte em si), ou como afirma Álvaro Lins, citado por Lafetá, dividido entre "o sentimento da terra e o sentimento íntimo de homem" ${ }^{22}$, o poeta que, de acordo com o autor de Figuração da intimidade, atinge a realização mais bem acabada por meio de poemas em que o "eu" se expande, explorando a subjetividade ${ }^{23}$, coloca, neste grupo de poemas, a intenção social do poeta modernista ao lado do canto íntimo do "eu”, reatualizando,

\footnotetext{
${ }^{20}$ Ibidem, p 69.

${ }^{21}$ Ibidem, p 70-1.

${ }^{22}$ LAFETÁ, J. L. Figuração da intimidade. São Paulo: Martins Fontes, 1986, p 4.

${ }^{23}$ Ibidem, p 6.
} 
dessa forma, o alaúde - a viola de amor -, usado, em Tempo da Maria, tanto para resgatar a identidade brasileira, reflexo de sua própria identidade, quanto para acalentar o sentimento íntimo do poeta lírico.

Além de estar presente no poema "O trovador", de Paulicéia desvairada, e no poema de abertura de Tempo da Maria, um instrumento de cordas, o instrumento do rapsodo, aparece, ainda, em outros momentos da obra do autor, como nas crônicas da série "De São Paulo" - "o alaúde vertiginoso da mocidade alegre e triunfal..." ${ }^{24}$-, publicadas entre 1920 e 1921, na Ilustração Brasileira, revelando a "longa gestação de um postulado estético", como afirma Telê Ancona Lopez ${ }^{25}$, assim como no primeiro poema de Lira paulistana. Em alguns momentos de Macunaíma, o herói ponteia uma viola de cocho $^{26}$, como afirma Cavalcanti Proença $^{27}$. Ainda na rapsódia, o contador de histórias, tendo ouvido as aventuras de Macunaíma narradas pelo papagaio que conhecia a fala impura da tribo desaparecida, ponteia em sua viola os casos do herói de nossa gente. A viola é invocada, também, por meio da única composição musical de Mário de Andrade - "Viola quebrada".

Acompanhado por uma viola - a viola de amor -, o poeta de Tempo da Maria tece o canto em que louva a dona ausente. Enquanto os marujos portugueses seqüestravam o desejo despertado pelas mulheres européias - mulheres brancas deixadas em Portugal -, por meio de cantigas, o poeta culto sublima os instintos carnais despertados pela dona casada, branca, com traços europeus $^{28}$, utilizando-se não apenas do ritmo popular, mas invocando ainda a imagem do instrumento erudito - a viola de amor. Dessa forma, a sobreposição do instrumento europeu ao ritmo brasileiro da moda, assim como a coexistência de sentimentos opostos - ser atraído por Maria e, ao mesmo tempo, repelido pela sua condição de dona casada - em "Moda do corajoso", embala o desejo do eu lírico, traduzindo o enfrentamento, em solo brasileiro, de culturas diferentes que formam o Brasil multifacetado.

De acordo com Mário de Andrade, no texto "A dona ausente", o desejo pela mulher distante foi recalcado na cultura popular, fazendo com que a imagem da dona sofresse diferentes formas de transposição - realizada por meio da tradição de se dar nomes de

\footnotetext{
${ }^{24}$ De São Paulo: cinco crônicas de Mário de Andrade, 1920-1921. Organização, introdução e notas de Telê Ancona Lopez. São Paulo: Editora Senac São Paulo, 2004, p 87.

${ }^{25}$ Ibidem, p 33-4

${ }^{26}$ Viola popular esculpida em um tronco de madeira inteiriço, a viola de cocho é conhecida como "o alaúde brasileiro", como nos lembra Ricardo Correia (CORREA, R, op. cit., p 23-4).

${ }^{27}$ PROENÇA, M. C. Roteiro de Macunaíma. Rio de Janeiro: Civilização Brasileira; Brasília: INL, 1977, p 137.

${ }^{28}$ Traz os "cabelos curtos" à moda européia, "é quieta e clara, [...] rosicler" e tem o rosto avivado pelo rouge "rosto/ que o rouge aviva mansinho" - (versos de poemas do grupo Tempo da Maria).
} 
mulheres às embarcações, pela comparação de mulheres com peixes, criando a imagem da "mulher-peixe", e por meio da transposição da imagem da mulher desejada para a imagem da cana verde, símbolo que, entre outras coisas, invoca a dona ausente -, sendo, ainda, sublimado no tema das "Bandas d'Além", em que a dona ausente é colocada em posição inatingível - do outro lado do rio ("Coitadinho de quem tem/ o seu amor no ultramar"), no meio do mar, tentando chegar ao marujo, ou presa em um rochedo, sempre impedida, de alguma forma, de chegar ao rapaz ("a canoa virou", "o remo caiu" ou "é casada e tem marido") ${ }^{29}$. Da mesma maneira, o amor do eu lírico de "Moda do corajoso", proibido, à semelhança das quadras populares, pelo casamento da mulher amada ${ }^{30}$, é seqüestrado e, assim como nas cantigas do povo, a dona desejada toma uma outra forma: viola de amor - "Maria, viola de amor" ${ }^{31}$-, instrumento com características singulares que invocam a imagem da mulher amada.

O mito da Sereia é bem um caso de seqüestro, de "refoulement". Pois toda seqüestração é bem um compromisso pelo qual o que se quer esquecer (o marinheiro quer esquecer a mulher) é substituído por outra imagem que possa facilmente se transformar [na] imagem seqüestrada e nos transportar a esta novamente. Além disso o seqüestro tem sempre uma espécie de lado moral, que consiste em revestir a imagem que substituiu a imagem seqüestrada, de alguma forma [que] representa os males, as dificuldades etc que a imagem seqüestrada nos causa ${ }^{32}$.

O som pungente e doce da viola de amor, com expressão nasal, enternecedora e lânguida, revela um dos males provocados pela dona ausente: o enternecimento fatal do eu poético entregue à música - à atração - comovente, como o marinheiro entregue ao canto hipnótico da sereia. O som do instrumento de cordas percorre, como lembrança da fatalidade do desejo, os poemas de Tempo da Maria.

\footnotetext{
${ }^{29}$ ANDRADE, M. A dona ausente. Atlântico: revista luso-brasileira, Rio de Janeiro, n. 3, 1943, p 10-13.

30 "Ô pescador da barquinha O que é?

Ai qui tu vai iludido - Pruquê?

Qu'essa mulé-é-quem vai

É casada e tem marido." (ANDRADE, M. Peças para “A dona ausente”. In: As melodias do boi e outras peças. Preparação, introdução e notas de Oneyda Alvarenga. São Paulo: Duas Cidades; Brasília: Instituto Nacional do Livro, 1987, p 293).

${ }^{31}$ A substituição da imagem da mulher ausente pela viola aparece em quadra popular presente em um dos livros da biblioteca particular de Mário de Andrade: "Tenho minha viola nova/ Feita de pau de colher/ Pra mim dançar com ela,/ Já que não tenho mulher." (ROMERO, S. Cantos populares do Brasil. Rio de janeiro: Livraria Francisco Alves, 1897, p 197-8).

${ }^{32}$ ANDRADE, M. Dona Ausente (Manuscrito). In: CARVALHO, op. cit., p 150 (grifos nossos).
} 
Outros atributos da viola de amor também remetem o eu lírico à imagem da mulher. Cantada em outros momentos de Tempo da Maria - "Ai, Maria do perfil duro" -, a silhueta reta da amada, por exemplo, síntese tanto da postura empertigada de moça aristocrática, como da postura moral rígida de mulher casada, é evocada por meio do perfil chapado da viola de amor, com seu fundo feito com madeira plana. No entanto, quando vista de frente, a viola possui as curvas sinuosas de uma mulher sensual que traduzem a atração exercida pela dona no eu lírico, apesar da postura rígida de mulher proibida.

Uma outra característica da viola de amor, as duas aberturas simétricas para saída de som em forma de espada de fogo, revela a interdição do desejo, ao evocar a espada flamejante que aparece nas mãos do anjo que defende a árvore da vida, após a expulsão de Adão e Eva do paraíso $^{33}$, constituindo-se, portanto, como símbolo da razão que freia os impulsos instintivos. Assim, a viola de amor - Maria -, ao mesmo tempo em que atrai, de forma irresistível, o poeta, por meio de sua sonoridade doce e de suas curvas provocantes, traz ainda o estigma da proibição.

A maneira simétrica pela qual as duas espadas de fogo são dispostas, assim como a simetria da forma da viola, expressa "a unidade pela síntese dos contrários, [...] a redução do múltiplo ao um" ${ }^{34}$, revelando, portanto, a tensão existente entre opostos - a atração e a proibição exercidas pela mulher desejada -, sintetizados por meio da forma da viola de amor. O desenho simétrico do instrumento retoma a simetria do losango, marca da veste arlequinal do poeta fragmentado.

A viola, que simultaneamente atrai e repele - tem perfil duro e curvas sinuosas, traz em si a marca da proibição, por meio das espadas de fogo, e, ao mesmo tempo, a atração irresistível de seu canto, mostrando, ainda, a coexistência intrínseca do desejo e a da repulsão por meio de sua forma simétrica -, é a imagem usada para seqüestrar o desejo do eu lírico que, apesar de representar a realização da paixão somente no nível da sublimação, ordena, por meio de seu nome - viola - a violação - a transgressão, a profanação - da mulher. Assim, "violar" recebe dupla carga semântica: "musicar" o amor pela mulher, sublimando-o por meio do canto, e profanar a mulher, violando-a. Mesmo sublimado, o desejo de realização sexual continua a ressoar no poema como baixo-contínuo - um som insistente e constante que permeia as sublimações.

\footnotetext{
${ }^{33}$ CHEVALIER, J., GHEERBRANT, A. Dicionário de Símbolos. Rio de Janeiro: José Olympio, 2002, p 393.

${ }^{34}$ Ibidem, p 393.
} 
O arco, usado para pôr em vibração as cordas da viola de amor, fere - viola -, com sua forma fálica, o corpo de Maria - a viola -, no plano da sublimação, em que, como durante os sonhos, de acordo com Politzer, estudando Freud no livro Critique des fondements de la Psychologie, obra lida por Mário de Andrade, "um pensamento, o mais freqüentemente um desejo, é objetivado, posto em cena, vivenciado", como lembra Telê Ancona Lopez ${ }^{35}$. Assim como a viola de amor possui normalmente sete cordas principais, que são tocadas pelo arco, e sete cordas simpáticas, que vibram por ressonância, o poeta deseja os sentimentos mais profundos de Maria - o som das cordas simpáticas -, buscando aflorá-los sob o toque suave do arco na viola de amor $^{36}$.

O meu corpo encasquetou

De não gostar senão de uma...

Pois, pra não fazer feiúra,

Meu espírito sublima

O fogo devorador.

Faz da paixão uma prima,

Faz do desejo um bordão,

E encabulado ponteia

A malvadeza do amor.

Maria, viola de amor!...

"Pra não fazer feiúra" - declarar um amor proibido, pecado grave, ou reprimir os impulsos sexuais, correndo o risco de transformá-los em sintomas de histeria (falta de controle sobre atos e emoções) -, a razão - "o espírito" - do eu lírico sublima o instinto carnal - "o fogo devorador" -, transformando o desejo e a paixão nas cordas da viola. O apetite sensual do poeta figura no poema como o "bordão" - "a corda mais grave dos instrumentos de corda" ${ }^{37}$, revelando, por meio do som grave, os instintos sexuais mais baixos. Outro significado da palavra bordão - pau de arrimo, cajado - reforça, por meio de sua forma fálica, o caráter sexual do desejo do corajoso. A paixão, intensa inclinação afetiva obsessiva e arrebatadora que se sobrepõe à razão, aparece, no poema, transformada na "prima" - corda mais fina da viola - traduzindo, em música, sua intensidade. Assim, o poeta ponteia (verbo que exprime tanto o tocar com os dedos a viola popular brasileira, quanto o tanger o instrumento erudito com o arco) a malvadeza do amor, fazendo vibrar as cordas principais da

\footnotetext{
${ }^{35}$ LOPEZ, T. P. A. Mário de Andrade: ramais e caminhos. São Paulo: Duas Cidades, 1972, p 106 (Tradução livre do francês).

${ }^{36}$ As características da viola de amor, citadas acima, podem ser encontradas no The New Grove Dictionary of Musical Instruments.

${ }^{37}$ ANDRADE, M. Dicionário musical brasileiro. Belo Horizonte: Itatiaia, 1999, p 69.
} 
viola, a prima e o bordão, dois contrários (grave e agudo) que, sobrepostos, intensificam a contradição que marca o poema - a atração pelo proibido.

O embate de tons graves e agudos percorre "Moda do corajoso" fazendo lembrar os sons da prima e do bordão, exprimindo o sentimento contraditório do poeta que ama, mas é proibido de amar. O penúltimo verso da terceira estrofe - "Toda paixão é esquecida" -, por exemplo, após o tom grave da nasal - "paixão" -, é terminado por meio do "i" agudo final da palavra "esquecida", sons opostos que se destacam por estarem em posição tônica. O contraste entre o sonoro "ão" e o "i" límpido, desse verso, reforça a tensão existente entre a força do desejo carnal que arrebata o poeta e a decisão racional de esquecer a amada, criando, ainda, uma dissonância dada pela sobreposição dos dois tons, construindo um "ruim esquisito" na sonoridade.

O verso "Meu espírito sublima", da quinta estrofe, ao mesmo tempo em que revela o comportamento racional pretendido pelo poeta ao se propor sublimar o desejo impossível, é marcado pela sonoridade aguda das duas vogais tônicas que elevam a altura do tom do poema, traduzindo o soar da corda mais fina da viola - da prima. Em um contraste sonoro, a linha seguinte - "O fogo devorador" - traz, por meio da gravidade de suas vogais, o som do bordão, reforçando a ardência grave do desejo. O contraste entre graves e agudos desses versos é retomado, de forma concisa, nas linhas que os seguem - "Faz da paixão uma prima,/ Faz do desejo um bordão". No primeiro, a nasal grave - "paixão" - contrasta com o "i" agudo de "prima" e, no segundo, o tom mediano da palavra "desejo" dá lugar ao grave "bordão".

Os embates sonoros do poema, tons graves e agudos das cordas da viola - a prima e o bordão -, além de ajudarem a construir a musicalidade contrastiva de "Moda do corajoso", reforçam a cisão que percorre a composição poética: a busca pela completude impossível, sinalizada por meio da mulher sensual, mas interdita ao desejo, invocando, ainda, a sensação de fragmentação que percorre a obra do poeta.

A atração exercida pelo amor impossível e a luta do eu lírico para esquecê-lo desenvolvem-se, no poema, em dois tempos opostos: o tempo presente, em que o amor se impõe como fatalidade, apesar da consciência do eu lírico da impossibilidade de realização amorosa, e o tempo futuro - tempo do esquecimento -, em que a paixão poderá ser arquivada. Mesmo afirmando, no presente, o despropósito de amar a dona inatingível - a dona casada -, o eu poético reconhece a força do desejo que o toma - "Mas quem que pode com o peito!" -, deixando, para o futuro, a solução do amor - "Meu amor terá seu fim".

Apesar de pretender "arquivar" o desejo amoroso, tentando iniciar, mesmo no presente, a superação do sentimento não correspondido - "Já estou curando a ferida" -, a 
lembrança da amada não abandona o eu lírico de "Moda do corajoso", criando um embate entre opostos: a racionalidade, que leva o eu poético ao propósito de superar a paixão, e a sensualidade despertada pelo desejo. A alternância, no poema, entre a intenção de ser racional e o desejo carnal cria um choque de forças: a volúpia amorosa que toma o eu poético - "Mas quem que pode com o peito!/ Amar não é desrespeito" - é interrompida pela proposição de, no futuro, domá-la - "Meu amor terá seu fim/ Maria há-de ter um fim" -, assim como a certeza racional do esquecimento futuro - "Se dando tempo pro tempo/ Toda paixão é esquecida. /Maria será esquecida." - é abalada pela constatação trágica da fatalidade do desejo amoroso - "Que bonita que ela é!... Não/ Me esqueço dela um momento".

As afirmações do eu lírico acerca do esquecimento, no futuro, da dona ausente apontam a fugacidade dos desejos amorosos: Maria será amada apenas por um período - o Tempo da Maria. Dessa forma, o eu poético parece acreditar na passagem contínua e linear do tempo como solução para o desejo que não o abandona. No entanto, o título do grupo de poemas nos faz lembrar expressões como "tempo da colheita", "tempo da salga" ou "tempo das águas" (este último, nome dado a um dos poemas do livro Clã do jabuti), em que um evento, encerrado transitoriamente, retorna por meio de um movimento cíclico constante. Assim, enquanto o eu poético afirma categoricamente a certeza do esquecimento, no futuro, do amor por Maria, acreditando na linearidade do tempo, um meio contínuo no qual os acontecimentos parecem suceder-se em momentos irreversíveis, o título dado a esse grupo de poemas, ao invocar o tempo cíclico, ou mítico, que sempre retorna, deixa entrever a incerteza: o amor terá um fim ou ficará apenas guardado (arquivado) nas dobras da lembrança, podendo ser rememorado (revivido) nos moldes da retomada cíclica das estações, como um dos amores eternos do poeta invocados no conto "Vestida de preto"? ${ }^{38}$ - "quatro amores eternos [...] fazem de minha vida uma grave condensação interior. Sou falsamente um solitário. Quatro amores me acompanham, cuidam de mim, vêm conversar comigo" 39 . A fugacidade amorosa, expressa, no poema, pelo eu lírico, ao lado da insinuação de um amor eterno, apreendida a partir do título do grupo de poemas - Tempo da Maria -, são opostos que se conjugam, constituindo-se como um dos traços dissonantes de "Moda do corajoso".

Podendo ou não, no futuro, esquecer a amada, no tempo presente, o cantador de "Moda do corajoso", hesitante entre a consciência do despropósito de seu amor e, ao mesmo tempo, tomado por ele, refugia-se em seu próprio cantar como forma de seqüestrar o amor impossível que o toma. Assim como o eu lírico de Vida nova, deslumbrado ao admirar a

\footnotetext{
${ }^{38}$ Escrito entre 1939 e 1943.

${ }^{39}$ ANDRADE, M. Contos novos. Belo Horizonte; Rio de Janeiro: Itatiaia, 1999, p 25.
} 
sublime Beatriz, que o levava, ao contemplá-la, àquela "parte da vida além da qual não se pode ir com a intenção de retornar" ${ }^{40}$, encontra, em suas palavras de louvor à amada, a beatitude - a realização amorosa de forma sublimada -, também o eu lírico de Tempo da Maria procura, por meio da louvação da mulher casada, atingir as delícias do desejo sublimado, fugindo do arrebatamento do amor carnal.

O sequiestro do desejo, realizado quando o eu lírico toca a viola e não a mulher, é similar ao mito de Pã, incorporado à tradição portuguesa e brasileira, em que uma jovem, para defender-se do assédio do deus, pede ajuda aos moradores do Olimpo e é transformada na cana-verde, uma das formas da dona inatingível, como afirma Mário de Andrade no texto "A dona ausente" 41 .

Pan, vendo subitamente contrariados seus desejos e esforços, desarreiga uma cana e faz dela flauta, a fim de sequer ao menos poder levar aos lábios, no colóquio de um longo beijo, a esquiva ninfa, cujo apetecido corpo já não é mais que essa débil haste, oca e sonora. ${ }^{42}$

Assim como no mito, o desejo interdito do eu lírico é realizado no plano da sublimação: o poeta fere as cordas da viola, levando-a ao rosto "no colóquio de um longo [abraço amoroso]", tirando, do instrumento sensível ao toque, delicados matizes de sonoridade.

No grupo de poemas de Mário de Andrade, o nome "Maria", comum no Brasil e freqüente em quadras populares ${ }^{43}$, proíbe o desejo do eu lírico, ao invocar as virtudes da mãe de Deus. O nome, além de tingir a imagem da mulher com aspectos da santidade, interdição maior para o desejo carnal, nos remete à contradição da figura de Nossa Senhora, que, apesar de virgem, torna-se mãe. Assim como Maria de Nazaré, a amada do poeta é, ao mesmo tempo, mulher ${ }^{44}$ e santa, pois, apesar de colocada em posição sagrada e inacessível, é desejada pelo eu lírico, tomado, como os jovens do Romantismo brasileiro, pelo amor e pelo medo. Assim, a contradição que permeia os versos de Tempo da Maria - ser atraído e repelido, ao

\footnotetext{
${ }^{40}$ ALIGUIERI, D. Da monarquia; Vida nova. Trad. de Jean Melville. São Paulo: Martin Claret, 2003, p 107.

${ }^{41}$ ANDRADE, M. A dona ausente. Atlântico: revista luso-brasileira, Rio de Janeiro, n. 3, 1943, p 11.

${ }^{42}$ ANDRADE, M. Dicionário musical brasileiro. Belo Horizonte: Itatiaia, 1999, p 93-94.

${ }^{43} \mathrm{O}$ nome Maria, além de ser comum nas peças folclóricas brasileiras, aparece com freqüência na série intitulada "Peças para a 'dona ausente"", colhida pelo poeta-pesquisador e publicada, depois, em livro por Oneyda Alvarenga - "Na barra grande ôh Maria/ No outro lado di lá", "Maria, passageira/ Venha me passá", "A barca virou [...] Por causa de Maria/ Que ela não soube remá” (ANDRADE, M. As melodias do boi e outras peças. Preparação, introdução e notas de Oneyda Alvarenga. São Paulo: Duas Cidades; Brasília: Instituto Nacional do Livro, 1987, p 294-8).

${ }^{44}$ Para o povo brasileiro, como nos lembra Mário de Andrade, "A mulher para ser mulher,/ deve se chamar Maria...” (ANDRADE, M. De um país sem mulheres. In: CARVALHO, op. cit., p 248.)
} 
mesmo tempo, pela mulher atraente, mas casada - toma forma também por meio da figura dúbia da mãe de Deus, invocada pelo nome da amada. Apesar de desejar fortemente a mulher, o poeta reconhece nela a figura sublime e inalcançável apontada pelo nome, pois Maria, em sua antiga forma hebraica - Maryám -, significa excelsa, sublime ${ }^{45}$. De forma semelhante, Dante reconhece em Beatriz os traços da mais elevada santidade - "quando ela se encontrava perto de alguém, vinha ao coração deste tanta honestidade que não ousava levantar os olhos nem responder à sua saudação" 46 .

A veneração à mãe de Deus marcou a vida de Mário de Andrade que, educado de forma católica no colégio dos Irmãos Maristas, foi também, quando jovem, congregado mariano. Mário - carregando no próprio nome o masculino de Maria - mesmo contestando, em certos momentos de sua vida, o ritualismo de sua religião, que se contrapunha à verdadeira fé cristã, mantém-se fiel ao catolicismo ${ }^{47}$. Levando-se em conta a presença da Virgem - da Igreja Católica - na vida do poeta, pode-se compreender a distância intransponível que se estabelece entre o eu lírico de "Moda do corajoso" e a amada inatingível que, por meio de seu nome, invoca a santidade da mãe de Deus, assim como o dilema vivido pelo eu poético que, apesar de estar consciente dessa distância, não consegue deixar de desejar Maria.

A adoração à Maria, em "Moda do corajoso", faz lembrar o poema à Virgem, de José de Anchieta - "De Beata Virgine Dei Matre Maria" -, escrito, de acordo com cronistas, nas areias da praia de Iperoig, quando o padre era refém dos perigosos índios tamoios. Em meio às negociações de paz e à conversão do gentil, o missionário jesuíta encontrou a tentação das índias nuas que a ele se ofereciam. O erotismo selvagem que se impôs a Anchieta deu origem ao poema à Virgem, sublimação dos desejos carnais que atormentavam o padre, realizada por meio da adoração da Mãe Pura, como se pode conferir em um dos livros da biblioteca particular de Mário de Andrade ${ }^{48}$.

$\mathrm{Na}$ época em que Anchieta andou por terras brasileiras, o sentimento do "seqüestro" era presença constante entre os portugueses aqui aportados, como afirma Mário em seus estudos sobre a dona ausente. De acordo com anotações do poeta-pesquisador, apesar da grande licenciosidade sexual existente no Brasil quinhentista, levando os portugueses a tomarem indígenas e negras como amantes, tanto a "consciência tradicional religiosa como a

\footnotetext{
${ }^{45}$ AZEVEDO, S. L. Dicionário de nomes de pessoas. Rio de Janeiro: Civilização Brasileira, 1993, p 395.

${ }^{46}$ ALIGUIERI, D, op. cit., p 128.

${ }^{47}$ Cf. LOPEZ, T. A. Ramais e caminhos. São Paulo: Duas Cidades, 1972, p 21-71.

${ }^{48}$ ANCHIETA, J. Cartas, informações, fragmentos históricos e sermões do padre Joseph de Anchieta. Civilização Brasileira: Rio de Janeiro, 1933, pp 13, 201-2, 239.
} 
presença constante do padre" acusavam a todo momento o pecado mortal ${ }^{49}$, fazendo com que os colonos desejassem a dona européia distante, com a qual poderiam se casar de acordo com as leis da Igreja. Para provar a falta da mulher branca entre os colonos, Mário cita carta de Manuel da Nóbrega, companheiro de Anchieta, em que o jesuíta pede o envio de órfãs com as quais os portugueses pudessem se casar, livrando-se, assim, do pecado ${ }^{50}$.

A tentação que, como missionário de Deus, Anchieta deveria ajudar a extirpar entre os colonos, atingiu o próprio padre, levando-o a buscar refúgio na imagem imaculada da Virgem Maria, invocada em seus versos. O poema do jesuíta, nascido do embate entre devoção e erotismo, lembra o dilema vivido pelo "corajoso" de Mário de Andrade, pois, como o padre, o eu lírico do texto modernista é afligido por desejos carnais, buscando a "salvação" no canto de louvor à Maria - mulher e santa. No entanto, o cantador do poema de Mário sobrepõe, na imagem de uma só mulher, a devoção e o erotismo - a mulher desejada e proibida -, diferente de Anchieta que encontra os dois opostos em mulheres diferentes - nas indígenas e na Santa.

Assim como a viola de amor do primeiro poema de Tempo da Maria indica tanto a sublimação do desejo, alcançada por meio da música da viola, quanto a confirmação da sensualidade, apreendida por meio do verbo "violar" - profanar -, o bordão, usado por Anchieta para escrever seu poema nas areias de Iperoig ${ }^{51}$, ao mesmo tempo em que possibilita a sublimação da sexualidade, ao ser usado para a escritura do poema, invoca a sensualidade carnal por meio da forma fálica, exprimindo, portanto, dois desejos contraditórios do padre: atingir o amor puro da Virgem Maria e saciar os desejos sensuais despertados pelas indígenas. No poema de Mário de Andrade, o vocábulo "bordão" também assume dupla conotação: é a sublimação do desejo, ao ser transformado em uma das cordas da viola, assim como, no outro sentido da palavra - cajado -, indica a exaltação da sexualidade por meio de sua forma.

O choque, vivenciado pelo jesuíta, entre as culturas européia, marcada pelas restrições morais católicas, e indígena, com forte caráter sexual, faz lembrar o tupi tangendo o alaúde ou o cantador brasileiro que tange a viola de amor -, imagens que revelam o poeta moderno consciente da sobreposição de culturas diferentes que formam o Brasil. No entanto, enquanto Anchieta é o representante da civilização européia que procura resguardar a virtude em meio ao erotismo indígena, o poeta é o brasileiro mestiço, resultado da soma de diferentes raças,

\footnotetext{
${ }^{49}$ ANDRADE, M. Seqüestro (Manuscrito). In: CARVALHO, op. cit., p 42.

${ }^{50}$ Ibidem, p 85.

${ }^{51}$ Imagem retratada por Benedito Calisto, em sua famosa tela "O Poema na praia", assim como por estudiosos e poetas, como Gonçalves de Magalhães, Varela e Machado de Assis. (Cf. CARDOSO, Pe A. Introdução. In: ANCHIETA, J. O Poema da Virgem. São Paulo: Edições Paulinas, 1958, p 31-36, 41-2).
} 
carregando, em seu ser, heranças diversas. O cantador de "Moda do corajoso" vive, portanto, com maior drama, o embate entre os desejos sexuais - herança tropical - e a necessidade de pureza - legado da cultura católica européia - que tem lugar dentro de seu próprio ser.

A atitude do eu poético de "Moda do corajoso" frente à mulher amada - consciente da distância intransponível entre eles e, ainda assim, sentindo o desejo constante de alcançá-la nos lembra o comportamento do ser humano frente ao sublime, estudado por Kant em Crítica da faculdade do juízo. Para o filósofo, o sublime é absolutamente grande, acima de toda comparação, causando, devido à grandeza que não pode ser totalmente compreendida, comoção e respeito naquele que o admira, sendo, ainda, atraente e assustador, ao mesmo tempo. Como lembra Kant, para compreender o sublime, o tememos sem fugir de sua contemplação, pois "o seu espetáculo só se torna tanto mais atraente quanto mais terrível ele é, contanto que, somente, nos encontremos em segurança" ${ }^{52}$. Dessa forma, o eu lírico de Tempo da Maria é atraído pelo perigo da mulher casada - pela mulher sublime e inatingível, beirando a santidade - e, sem fugir de sua contemplação, a admira, no entanto, em segurança - por meio dos versos em que seu amor aparece seqüestrado.

Como lembra Kant,

[...] sublime é aquilo em comparação com o qual tudo o mais é pequeno. [No entanto], aqui se vê facilmente que na natureza nada pode ser dado por grande [...] que, considerado em uma outra relação, não pudesse ser degradado até o infinitamente pequeno. [...]. O que é absolutamente grande não é, porém, o objeto dos sentidos, e sim o uso que a faculdade do juízo naturalmente faz de certos objetos para o fim daquele sentimento. ${ }^{53}$

Dessa forma, Maria só é sublime ao ser tomada como objeto do desejo de transcendência do eu lírico. A música emana da viola de amor - Maria -, mas nasce ao toque do sentimento do tocador. Além da palavra poética que elege a Moda para se expressar e da música que nasce dos versos, está o sentimento trágico do eu poético que vive a grande contradição de se sentir atraído pela mulher que, vista por meio desse sentimento, se faz sublime.

Em posição excelsa, a amada de Tempo da Maria personifica o "eterno feminino", expressão de Goethe, no segundo Fausto, "para designar a atração que guia o desejo do

\footnotetext{
${ }^{52}$ KANT, I. Crítica da faculdade do juízo. Tradução de Valério Rohden e António Marques. Rio de Janeiro: Forense Universitária, 1993, p 107.

${ }^{53}$ Ibidem, p 96.
} 
homem no sentido de uma transcendência" ${ }^{54}$. A mulher como guia para o sublime é encarnada, de acordo com Chevalier, na figura de Beatriz, de Dante, inspiração dos versos de Mário de Andrade, assim como na imagem da Virgem-Mãe, invocada, em Tempo da Maria, por meio do nome da amada. Como as duas, o eterno feminino desse grupo de poemas Maria - simboliza um desejo que não pode ser realizado, assim como uma forma de evasão o seqüestro "permanecido assim lírico e puro era um recanto de evasão para onde os espíritos descansavam, confessando a sua realidade sem a brutalidade dela e todos os sofrimentos e exasperos e saudades que ela acarretava" 55 .

Como vimos até aqui, o texto de abertura de Tempo da Maria, "Moda do corajoso", é formado por hibridismos que não apenas reforçam o sentimento trágico do eu lírico dividido entre o desejo e a impossibilidade de realização, como também desvelam uma poética de Mário de Andrade implícita nos versos do modernista. As várias sobreposições de opostos do poema mostram o poeta multifacetado sempre em busca de sua identidade que, assim como o país que o cerca, é composta por fragmentos, muitas vezes contraditórios, que coexistem em um mosaico.

Podemos verificar, em "Moda do corajoso", diferentes sobreposições que, uma ao lado da outra, apontam o caráter plural do brasileiro, sendo possível ordená-las em três grupos. No primeiro, o poeta erudito incorpora, a seu canto, formas típicas da tradição brasileira, procurando, assim, traduzir a nossa identidade, formada tanto por influência européia erudita como por influência popular. A sobreposição da cultura de origem européia à tradição do povo é sintetizada por meio do uso, no poema, de um instrumento europeu (viola de amor), ao se cantar uma moda caipira. Num segundo grupo, a sobreposição de opostos é revelada por meio da atração e da repulsão exercidas, ao mesmo tempo, pela mulher casada. O desejo e a interdição revelam-se por meio do nome de Maria, nome santo e, ao mesmo tempo, nome comum de mulher, que invoca, também, a dúbia posição da Mãe de Deus - mulher e santa -, assim como por meio da forma contraditória da viola de amor, símbolo que, como nos versos populares, substitui a imagem da dona ausente. Uma outra sobreposição de contrários é realizada, no poema, pelo jogo dos tempos presente e futuro (o desejo presente e o esquecimento futuro), além da sobreposição do tempo cíclico e do tempo linear, se levarmos em consideração o título do grupo - Tempo da Maria.

\footnotetext{
${ }^{54}$ CHEVALIER, J., GHEERBRANT, op. cit., p 421.

55 ANDRADE, M. Seqüestro (Manuscrito). In: CARVALHO, op. cit., p 50.
} 
A coexistência de opostos que não podem se fundir percorre a obra de Mário de Andrade, aparecendo de forma marcante no conto "Vestida de preto", do livro Contos novos (1947), em que dois momentos da vida de Juca, o narrador-personagem, são relatados: o momento sublime e puro do primeiro beijo entre as crianças Juca e Maria, interrompido bruscamente pelo olhar acusativo de Tia Velha, fazendo-os conhecer o pecado cometido; e o reencontro dos dois primos, depois de adultos. Se, no primeiro momento, antes da intervenção de Tia Velha, o beijo deixara o personagem "completamente puro, sem [...] desejos de mais nada" 56, ao se reencontrarem, adultos, qualquer contato entre ambos é pecado grave e somente a não realização do desejo é capaz de fazer reviver o momento sublime conseguido, antes, por meio do beijo - "meu desejo era fugir, era ficar e ela ficar mas, sim, sem que nos tocássemos sequer" ${ }^{57}$. O personagem vive, portanto, o amor e medo, nos moldes de Tempo da Maria. O momento da reprovação de Tia Velha, expulsando-os do quarto em que estavam a sós, faz lembrar a expulsão de Adão e Eva do paraíso, como afirma a estudiosa Maria Célia Paulilo $^{58}$, marcando os amantes com o estigma do pecado. A partir desse momento, a cisão entre os dois torna-se irremediável: quando novos, Maria repudia o Juca mau aluno, caso perdido da família e, quando adultos, os papéis se invertem - "se o que tinha de útil agora em mim era Maria, se ela estava se transformando no Juca imperfeitíssimo que eu fora [...] se nos trocáramos por um estúpido engano de amor: mas ao menos que eu ficasse bem ruim [...] outra vez, pra me igualar a ela de novo." 59

Em "Moda do corajoso", as sobreposições de opostos são colocadas em evidência pela própria forma do poema que, como "serpente mordendo o rabo" ${ }^{60}$, é finalizado com a retomada do verso da primeira estrofe - "Maria, viola de amor" -, assumindo a forma da uróboro, símbolo do eterno retorno e da união entre opostos, invocando a coexistência tensa de contrários que permeia a obra de Mário de Andrade, sinal do "grande dilaceramento [do poeta]" ${ }^{61}$ preocupado em apreender a face múltipla de seu país. No entanto, não é possível atingir a unidade, apenas explicitar a pluralidade entrevista por Mário de Andrade na alma

\footnotetext{
${ }^{56}$ ANDRADE, M. Contos novos. Belo Horizonte; Rio de Janeiro: Itatiaia, 1999, p 21.

${ }^{57}$ Ibidem, p 25.

${ }^{58}$ PAULILO, M. C. Contos da plenitude. In: ANDRADE, M. Contos novos. Belo Horizonte; Rio de Janeiro: Itatiaia, 1999, p 13.

${ }^{59}$ ANDRADE, M. Contos novos. Belo Horizonte; Rio de Janeiro: Itatiaia, 1999, p 24.

${ }^{60}$ Mário escreve, em 1925, em carta a Manuel Bandeira: “A forma mais universal e popular é incontestavelmente a da circunferência: serpente mordendo o rabo, a gente acaba por onde principiou e fica o moto-contínuo balançando sensação. Não derruba a gente assim na realidade" (ANDRADE, M. Cartas a Manuel Bandeira. Rio de Janeiro: Edições de Ouro, 1967, p 104).
}

${ }^{61}$ SOUZA, G. M. O tupi e o alaúde. São Paulo: Duas Cidades, 1979. p 56. 
brasileira, assim como em seu próprio ser fragmentado. Como lembra Bastide, "não é impunemente que a mais querida [mulher dos poemas de Mário] talvez seja esta Maria, porque não pode fundir-se nele, porque é diferente, esta Maria que fala inglês e não caboclo" 62.

Procurando compreender a face complexa de seu ser e de seu país, Mário de Andrade resgata, em seus versos, traços populares, atualizando um tema próprio do povo - o tema da "dona ausente" -, por meio da forma musical da moda.

De acordo com Mário de Andrade, em seu Dicionário Musical Brasileiro, moda é "poesia cantada com acompanhamento especialmente de viola [...], reconto dum caso qualquer mais ou menos sensacional, ou dum fenômeno importante da vida quotidiana, historiado" 63 . Tangendo a viola de amor, o eu lírico da "Moda do Corajoso" canta uma das ocorrências da vida cotidiana brasileira - o sentimento do seqüestro -, utilizando-se da redondilha maior, medida comum da tradição popular do Brasil, resgatando, assim, o ritmo musical que, ao lado do instrumento erudito, define nossa identidade fragmentada.

Como lembra Mário, o caipira legítimo não conhece como Moda "uma série de quadras soltas" ${ }^{64}$, mas sim a composição que, de acordo com o estudioso, aproxima-se do romance nordestino, constituído por sextilhas e décimas, forma usada pelo poeta em "Moda do Corajoso" - além dos dois versos iniciais, que compõem a primeira estrofe ("Maria dos meus pecados,/ Maria, viola de amor...”), e a retomada, na última estrofe de apenas um verso, de "Maria, viola de amor...", três sextilhas (segunda, terceira e quarta estrofes) e uma décima (quinta estrofe) formam o poema. A retomada da primeira estrofe - refrão da moda - , no último verso do texto poético, é também construção típica da tradição popular, em que o poema "acaba por onde principiou" ${ }^{65}$, evocando, como afirmado acima, a figura circular da uróboro, sendo, ainda, como nos lembra Mário de Andrade, citando Carolina Michaëlis, um processo antigo, comum entre os trovadores.

O refrão inicia e acaba a cantiga. Este processo é antiguíssimo com os trovadores. Carolina Michaëlis nas notas ao "Cancioneiro da Ajuda" [...] afirma [...]: "Antigamente iam (as estrofes) acompanhadas de um refrão curto e singelo que rematava cada estrofe [...] Como tema e elemento distintivo musical era às vezes anteposto à poesia, servindo-lhe de cabeça e pé. [...]' Ora

\footnotetext{
${ }^{62}$ BASTIDE, R. Poetas do Brasil. São Paulo: Edusp; Duas Cidades, 1997, p 79.

${ }^{63}$ ANDRADE, M. Dicionário musical brasileiro. Belo Horizonte: Itatiaia, 1999, p 342.

${ }^{64}$ Ibidem, p 342.

${ }^{65}$ ANDRADE, M. Cartas a Manuel Bandeira. Rio de Janeiro: Edições de Ouro, 1967, p 104.
} 

${ }_{66}$ Bo Brasil estes costumes continuam e eu podia citar um dilúvio de exemplos.

Assim como os trovadores perambulavam pelos castelos recitando cantigas de amor, acompanhados pela viola, formando o Trovadorismo - movimento "fixador de línguas, influenciador de música, primeiro reflexo étnico das nações na música do Cristianismo", como afirma Mário de Andrade ${ }^{67}$-, o poeta, ponteando sua viola, como antes tangera o alaúde, no poema "O trovador", de Paulicéia desvairada, entoa sua cantiga de amor - a "Moda do corajoso" -, fixando a língua brasileira, ao utilizar expressões marcadas por um forte sabor de oralidade - "não tem propósito", "quem que pode", "dando tempo pro tempo", "encasquetou", "pra não fazer feiúra" -, ao mesmo tempo em que busca conhecer o caráter da música do Brasil.

A forma popular da Moda aproxima-se das cantigas dos trovadores e dos menestréis por ser "rapsódica por excelência. Ela [...] repete, na mais exata expressão, o fenômeno dos rapsodos gregos, indianos, da Rússia, e dos menestréis medievais”, como nos ensina Mário de Andrade ${ }^{68}$. Assim como o rapsodo "recita ou canta histórias populares adaptando-as a seu modo" ${ }^{69}$, o trovador da "Moda do Corajoso" utiliza-se de um tema próprio do povo - o seqüestro - e de processos de composição inspirados em nossa tradição para construir, também, o seu canto a seu modo, afirmando-se como o rapsodo brasileiro. Enquanto os marujos portugueses evitavam falar abertamente sobre o sofrimento causado pelo distanciamento da amada, sublimando, em um processo inconsciente, o desejo, e transformando a dor em canções em que a mulher aparece sublimada ${ }^{70}$, o poeta modernista lida com a falta da dona ausente de forma racional: fala abertamente sobre o despropósito de

\footnotetext{
${ }^{66}$ ANDRADE, M. A influência portuguesa na música popular brasileira. In: As melodias do boi e outras peças. Preparação, introdução e notas de Oneyda Alvarenga. São Paulo: Duas Cidades; Brasília: Instituto Nacional do Livro, 1987, p 379. (Publicado, postumamente, por Oneyda Alvarenga em As melodias do boi e outras peças, esse texto deu origem ao ensaio "Influência portuguesa nas rodas infantis do Brasil", escrito em 1929 e publicado em Música, doce música).

67 ANDRADE, M. Pequena história da música. Belo Horizonte: Itatiaia, 2003, p 62 (livro publicado originalmente com o título Compêndio de história da música, em 1929).

${ }^{68}$ ANDRADE, M. Dicionário musical brasileiro. Belo Horizonte: Itatiaia, 1999, p 343.

${ }^{69}$ Ibidem, p 427.

70 “A saudade, principalmente amplificada pelo desejo sexual, é penosa e a ambição da conquista [..] os levava a evitar recordações e pensamentos penosos que os enfraquecessem, afrouxassem. [...] Pela força penosa das verificações a que induzia a confissão textual da falta de mulher, se explica a razão dessa falta ter sido seqüestrada com tamanha veemência pelo português, pelo espanhol e pelos brasileiros dos primeiros séculos, a ponto do folclore, que eu saiba, não apresentar nenhum documento de nenhum gênero verificando com franqueza a falta que fazia a dona ausente. E a 'censura' explica a transposição da idéia, que devia ser obsecante, prás descrições tão graciosas do seqüestro, apresentadas pelo nosso folclore.” (ANDRADE, M. Seqüestro (Manuscrito). In: CARVALHO, op. cit., p 42-6)
} 
desejar a mulher proibida, decidindo racionalmente sublimar o desejo, tornando-o, assim, suportável - "Pois, pra não fazer feiúra,/ Meu espírito sublima/ O fogo devorador". Dessa forma, o eu lírico é o rapsodo que, a seu modo, atualiza o seqüestro da dona ausente, tema comum no nosso imaginário, deixando transparecer a voz do poeta moderno que conhece Freud e reflete sobre teorias psicanalíticas que instrumentam reflexões sobre o caráter de um povo.

Além de utilizar-se de redondilhas maiores, da divisão de estrofes em sextilhas e décimas, do resgate da cadência da oralidade do povo brasileiro, assim como do refrão que inicia e termina o poema, aproximando-se, ainda, das rapsódias, ao adaptar, ao olhar modernista, um tema popular, o poeta de "Moda do corajoso", tentando compreender seu país multifacetado, resgata um outro aspecto próprio da tradição musical brasileira: o caráter improvisatório, típico da moda, como nos ensina Mário de Andrade.

\begin{abstract}
Notar que a linha melódica das modas é eminentemente improvisatória, no sentido mais musical da palavra. [...] Há por assim dizer uma preguiça de melodizar nelas. Por mais fixas que sejam suas linhas melódicas, repetindose exatamente de estrofe a estrofe, a indecisão da linha, da evolução harmônica, a moleza de movimento tornam eminentissimamente vaga, improvisatória, quase oratória. É no sentido mais legítimo do termo, um recitativo $^{71}$.
\end{abstract}

No poema, apesar da regularidade aparente dada pela metrificação - versos em redondilha maior - e pela divisão regular de estrofes - sextilhas e décimas -, o improviso pode ser percebido por meio da "moleza de movimento", malemolência típica do brasileiro, traduzida, no poema, por meio de variações na acentuação silábica que o tornam "quase oratório", aproximando-o do recitativo - "forma de canto declamado com acompanhamento de baixo contínuo. [...] De forma bastante livre, o acompanhamento [segue] o ritmo declamatório do cantor" ${ }^{72}$. No Brasil, as modas de viola assumem a forma de canto recitado, em que a voz do cantador, marcada pelo improviso, tem importância maior do que o acompanhamento instrumental. No primeiro poema de Tempo da Maria, não podendo se utilizar do instrumento real, o eu lírico faz da amada sua viola e transforma a paixão e o desejo nas cordas que acompanham o ritmo solto da moda.

\footnotetext{
${ }^{71}$ ANDRADE, M. Dicionário musical brasileiro. Belo Horizonte: Itatiaia, 1999, p 343.

${ }^{72}$ Ibidem, p 430.
} 
MODA DO CORAJOSO ${ }^{73}$

Maria dos meus pecados,

Maria, viola de amor...

Já sei que não tem propósito

Gostar de donas casadas,

5 Mas quem que pode com o peito!

Amar não é desrespeito,

Meu amor terá seu fim.

Maria há-de ter um fim.

Quem sofre sou eu, que importa

10 Pros outros meu sofrimento?

Já estou curando a ferida.

Se dando tempo pro tempo

Toda paixão é esquecida.

Maria será esquecida.

15 Que bonita que ela é!... Não

Me esqueço dela um momento!

Porém não dou cinco meses,

Acabarão as fraquezas

E a paixão será arquivada.

20 Maria será arquivada.

Por enquanto isso é impossível.

$\mathrm{O}$ meu corpo encasquetou

De não gostar senão de uma...

Pois, pra não fazer feiúra,

25 Meu espírito sublima

O fogo devorador.

Faz da paixão uma prima,

Faz do desejo um bordão,

E encabulado ponteia

30 A malvadeza do amor.

Maria, viola de amor!...

A maior parte dos versos do poema tem a $2^{\mathrm{a}}$, a $4^{\mathrm{a}}$ e a $7^{\mathrm{a}}$ ou a $2^{\mathrm{a}}$, a $5^{\mathrm{a}}$ e a $7^{\mathrm{a}}$ sílabas métricas acentuadas. O deslocamento da tônica, em alguns momentos, da quarta para a quinta sílaba métrica, cria uma oscilação que dá forma ao improviso, sentido também por meio da mudança da primeira sílaba tônica para a terceira sílaba métrica, nos versos 7, 19 e 21 .

A variação da acentuação, que cria o movimento malemolente do improviso, é sentida, ainda, por meio dos versos 10,13,18,22, 23 e 25 a 30, em que apenas duas sílabas são acentuadas. O menor número de tônicas em linhas que seguem a mesma metrificação

\footnotetext{
${ }^{73}$ Os versos estão numerados, à esquerda, com o número do verso e, à direita, com o número das sílabas tônicas,
} 
(redondilha maior) dá agilidade aos versos, lidos de maneira mais acelerada em comparação com aqueles que possuem três sílabas fortes. A maior quantidade de sílabas fracas, na partitura poética, cria momentos em que um movimento rápido - sequiência de "notas" tocadas rapidamente, com valor de tempo menor que as demais notas (sílabas métricas) do poema - é executado, contrastando com as linhas que possuem maior número de tônicas. Assim, desvela-se, por meio da variação rítmica - versos mais lentos e mais ágeis -, o improviso.

Nas linhas em que apenas a $4^{\mathrm{a}}$ e a $7^{\mathrm{a}}$ sílabas são acentuadas, as três primeiras sílabas métricas são lidas rapidamente, construindo o ritmo do poema.

$$
\begin{array}{ll}
13 & \text { Toda paixão é esquecida. } \\
\mathbf{1 8} & \text { Acabarão as fraquezas } \\
\mathbf{2 3} & \text { De não gostar senão de uma... } \\
\mathbf{2 7} & \text { Faz da paixão uma prima, } \\
\mathbf{2 8} & \text { Faz do desejo um bordão, } \\
\mathbf{2 9} & \text { E encabulado ponteia } \\
\mathbf{3 0} & \text { A malvadeza do amor. }
\end{array}
$$

Nos versos 10, 22, 25 e 26, com o primeiro acento tônico na segunda ou na terceira sílabas métricas, as sílabas intermediárias ganham maior rapidez.

$$
\begin{aligned}
& \mathbf{1 0} \text { Pros outros meu sofrimento? } \\
& \mathbf{2 2} \text { O meu corpo encasquetou } \\
& \mathbf{2 5} \text { Meu espírito sublima } \\
& \mathbf{2 6} \text { O fogo devorador. }
\end{aligned}
$$

A agilidade dos versos marcados pela menor quantidade de sílabas tônicas constrói "movimentos melódicos aparentemente sincopados, porém desprovidos de acento, respeitosos da prosódia, ou musicalmente fantasistas, [...] movimentos enfim inteiramente pra fora do compasso ou do ritmo em que a peça vai”, próprios da música do povo brasileiro, como afirma Mário de Andrade em texto de $1928^{74}$.

"Verdadeiro deslocamento do acento forte que passa do lugar teórico para um lugar onde ele não devia cair, verdadeira antecipação rítmica da thesis [tempo forte do compasso]" 75 , como nos lembra Mário de Andrade, a síncope, insinuada nos versos com menor número de acentos tônicos, aparece, de forma clara, nas linhas 15 e 16 do poema.

\footnotetext{
${ }^{74}$ ANDRADE, M. Ensaio sobre a música brasileira. São Paulo: Livraria Martins, 1967, p 37.

${ }^{75}$ ANDRADE, M. Dicionário musical brasileiro. Belo Horizonte: Itatiaia, 1999, p 475-6.
} 
15 Que bonita que ela é!... Não

(3-7) [8]

16 Me esqueço dela um momento!

Nesses versos, Mário de Andrade faz uso do mesmo recurso apontado por ele no poema "Fuga" de Carlos Drummond de Andrade, um tempo depois, no ano de $1930^{76}$. De forma similar ao verso do poeta mineiro - "E todo mundo anda - como eu - de luto" -, a linha 15 de "Moda do corajoso", apesar de ser formada por oito sílabas métricas, possui um "parêntese rítmico" - "Não" - que preserva a metrificação do poema - redondilha maior. Além disso, o vocábulo "não", deslocado, é a antecipação do acento forte que pertenceria ao próximo verso - “(Não) me esqueço dela um momento" -, processo criador da síncope musical que dá ao poema o descompasso e o requebro típicos do ritmo da música e da dança brasileiras.

Como acreditava Mário de Andrade, nascida do contato entre a rítmica oratória de ameríndios e negros e marcada, ainda, pelo mensuralismo europeu, a síncope é fruto de influências díspares, tendo-se tornado uma das formas características da música brasileira.

Se deu pois na música brasileira um conflito entre a rítmica diretamente musical dos portugueses e a prosódica das músicas ameríndias, também constante nos africanos aqui. [...] A essas influências díspares e a esse conflito inda aparente o brasileiro se acomodou, fazendo disso um elemento de expressão musical. [...] $\mathrm{O}$ brasileiro se acomodando com os elementos estranhos e se ajeitando dentro das próprias tendências adquiriu um jeito fantasista de ritmar. Fez do ritmo uma coisa mais variada e livre e sobretudo um elemento de expressão racial. ${ }^{77}$

Resgatando a síncope, o poeta invoca, em "Moda do corajoso", o ritmo brasileiro revelador do nosso caráter mestiço, fruto do contato e da assimilação de culturas diferentes. $\mathrm{O}$ saracotear sincopado, que se desenvolve no intervalo criado por acentuações fora do lugar específico, "acentuações deslocadas [que] levam a dança a balançar como se estivesse entre [...] dois pulsos simultâneos e defasados, criando-se entre eles frações de vazio", resultado da soma de sistemas rítmicos opostos ${ }^{78}$, como afirma José Miguel Wisnik, reforça a tensão do poema, exposta por meio de diferentes contradições.

\footnotetext{
${ }^{76}$ ANDRADE, M.A poesia em 1930. In: Aspectos da Literatura Brasileira. Belo Horizonte:Itatiaia, 2002,p 42-3.

77 ANDRADE, M. Ensaio sobre a música brasileira. São Paulo: Livraria Martins, 1967, p 31-2.

${ }^{78}$ WISNIK, J. M. Machado maxixe: o caso Pestana. Teresa: Revista de Literatura Brasileira, Departamento de Letras Clássicas e Vernáculas. Faculdade de Filosofia, Letras e Ciências Humanas. Universidade de São Paulo. São Paulo: Ed. 34, n. 4/ 5, 2003, p 36.
} 
A antecipação do vocábulo "não", além de construir o ritmo entrecortado da síncope, possibilita duas leituras diferentes dos versos. Em uma primeira leitura, o "não" aparece como negação assustada do eu lírico que interrompe o seu devaneio amoroso numa tentativa de conter o desejo que volta a aflorar, ao lembrar-se da beleza de Maria - "Que bonita que ela é!... Não". Ao mesmo tempo, uma outra leitura se constrói: a palavra "não", completada pela frase seguinte, realça a impossibilidade de esquecer a amada - "Não/ me esqueço dela um momento". A oscilação entre o desejo e a repressão dos sentimentos, presente nos versos 15 e 16, percorre o poema, que se constrói por meio do balanço entre a intenção racional do eu lírico que pretende, no futuro, subjugar a paixão e a constatação da presença incessante da fatalidade amorosa, no tempo presente, variação revelada, também, por meio do ritmo do poema.

Nos momentos de valorização do desejo amoroso, os versos são marcados por reticências e pontos de exclamação, expressando o enlevo que toma o eu lírico.

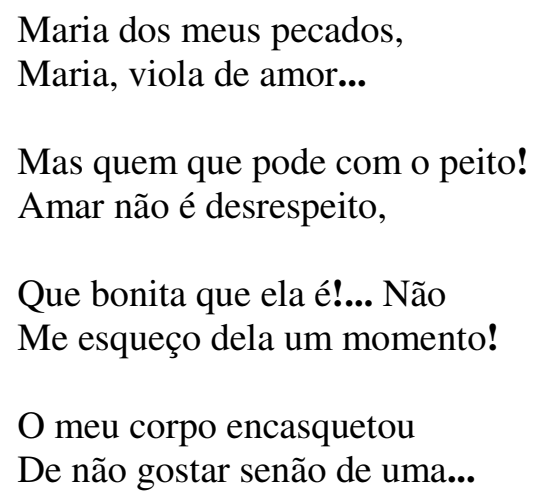

Em contraste, os pontos finais incisivos dos dois últimos versos das sextilhas indicam, por meio da interrupção abrupta que corta, muitas vezes, a cadência da frase - "Se dando tempo pro tempo/ Toda paixão é esquecida./Maria será esquecida." -, a decisão racional de, no futuro, pôr fim ao desejo amoroso, criando, no poema, cortes rítmicos. Além disso, as interrupções singulares lembram a batida da viola arrematando a fala do cantador de modas, construindo, assim, a sonoridade do poema. Ao lado dos cortes causados por pontos finais, a repetição insistente de palavras que invocam o futuro esquecimento da amada - "fim", "esquecida" e "arquivada" - mostra o empenho decidido do eu lírico que quer se convencer da necessidade de esquecer o amor sentido por Maria. 
Toda paixão é esquecida.

Maria será esquecida.

E a paixão será arquivada.

Maria será arquivada.

Nos versos finais das sextilhas, o nome da amada - "Maria" - insinua-se como nota insistente da composição musical que, aparecendo em posição destacada no início dos últimos versos, marca o refrão do poema, desvelando, assim, a musicalidade da composição poética. Ao decidir esquecer a mulher atraente, o eu poético repete, paradoxalmente, seu nome, traindo o desejo de não perdê-la.

Consciente da impossibilidade de "arquivar" o desejo pela mulher amada no momento vivido, empreitada deixada para um futuro próximo - "Porém não dou cinco meses,/ Acabarão as fraquezas" -, o eu poético decide entregar-se, na penúltima estrofe, ao prazer sublimado. Enquanto os pontos finais insistentes das segunda, terceira e quarta estrofes cortam a fluidez do discurso, mostrando a intenção do eu lírico de esquecer Maria, na quinta estrofe, em que o eu poético decide se entregar ao desejo realizado por meio da sublimação, os pontos finais, espalhados pelos versos, não atrapalham a fluidez rítmica.

$\begin{array}{lll}\mathbf{2 1} & \text { Por enquanto isso é impossível. } & \mathbf{( 3 - 5 - 7 )} \\ \mathbf{2 2} & \text { O meu corpo encasquetou } & \mathbf{( 3 - 7 )} \\ \mathbf{2 3} & \text { De não gostar senão de uma... } & \mathbf{( 4 - 7 )} \\ \mathbf{2 4} & \text { Pois, pra não fazer feiúra, } & \mathbf{( 3 - 5 - 7 )} \\ \mathbf{2 5} & \text { Meu espírito sublima } & \mathbf{( 3 - 7 )} \\ \mathbf{2 6} & \text { O fogo devorador. } & \mathbf{( 2 - 7 )} \\ \mathbf{2 7} & \text { Faz da paixão uma prima, } & \mathbf{( 4 - 7 )} \\ \mathbf{2 8} & \text { Faz do desejo um bordão, } & \mathbf{( 4 - 7 )} \\ \mathbf{2 9} & \text { E encabulado ponteia } & \mathbf{( 4 - 7 )} \\ \mathbf{3 0} & \text { A malvadeza do amor. } & \mathbf{( 4 - 7 )} \\ & & \\ \mathbf{3 1} & \text { Maria, viola de amor!... } & \mathbf{( 2 - 4 - 7 )}\end{array}$

Não sendo interrompida de forma marcante por pontos finais insistentes, a penúltima estrofe desenvolve uma musicalidade peculiar que, em comparação com os versos anteriores, demonstra maior fluidez, conseguida, também, por meio do agrupamento de linhas com apenas duas sílabas acentuadas, cadência sincopada que dá um ritmo singular ao período. $\mathrm{O}$ ritmo mais solto e dançante da penúltima estrofe reinventa, no poema, o "recortado", maneira 
popular de finalizar a moda de viola ${ }^{79}$, exemplificada, pelo poeta, por meio da moda “Escoieno Noiva”, de Cornélio Pires, áudio disponível no Arquivo Mário de Andrade do IEB$\mathrm{USP}^{80}$.

O jogo com a plasticidade sonora dos fonemas tece, também, a música da composição poética, já que diferentes timbres fonéticos - notas musicais - são organizados em uma melodia singular. Levando em conta as vogais das sílabas tônicas do poema, percebemos a alternância entre graves e agudos que constrói a melodia de "Moda do corajoso", lembrando a fala dos cantadores, marcada pela riqueza melódica da alternância de tons altos e baixos. No primeiro verso da estrofe inicial - "Maria dos meus pecados" -, por exemplo, parte-se da vogal "i", aguda, passa-se por um rebaixamento de tom, por meio da vogal "e", fechada, atingindo, depois, o “a” grave final. Já em "Maria, viola de amor...”, após o “i” agudo, sobe-se o tom por meio do "ó" aberto, rebaixando-o por meio do "o" fechado final, timbre grave estendido pelas reticências. O tom decrescente desses versos, característico da melódica brasileira, como afirma Mário de Andrade, em texto de 1928 - "a nossa melódica afeiçoa as frases descendentes" ${ }^{81}$-, aparece ainda em outros momentos do poema, aproximando a composição poética da melodia descendente dos cantadores caipiras, traço comum, especialmente, nos finais de estrofe das modas de viola - "Maria há-de ter um fim", "Maria será arquivada", "A malvadeza do amor".

Além disso, percebemos a musicalidade do poema por meio de suas rimas, como podemos conferir por meio da terceira estrofe.

9 Quem sofre sou eu, que importa
$\mathbf{1 0}$ Pros outros meu sofrimento?
$\mathbf{1 1}$ Já estou curando a ferida.
$\mathbf{1 2}$ Se dando tempo pro tempo
$\mathbf{1 3}$ Toda paixão é esquecida.
$\mathbf{1 4}$ Maria será esquecida.

A intercalação das repetições desta estrofe é similar à disposição das rimas dos versos da modinha "Praieira", uma das "Peças para 'A dona ausente" colhida, em 1929, por Mário de Andrade, em sua viagem ao nordeste do país. Popular no Rio Grande do Norte, na época da viagem do poeta-pesquisador, a canção é lembrada por Mário em trecho do Turista

\footnotetext{
${ }^{79}$ ANDRADE, M. Dicionário musical brasileiro. Belo Horizonte: Itatiaia, 1999, p 432.

${ }^{80}$ A música popular brasileira na vitrola de Mário de Andrade. Texto pesquisado e comentado por Flávia Camargo Toni. São Paulo: Editora Senac São Paulo, 2004, p 110.

${ }^{81}$ ANDRADE, M. Ensaio sobre a música brasileira. São Paulo: Livraria Martins, 1967, p 47.
} 
aprendiz - "Aqui em casa também. Todos cantamos, cocos, embolados, sambas, dobrados, modinhas... A famanada 'Praieira'..." 82.

Praieira dos meus amores

Encanto do meu olhar

Quero contar-te os rigores

Sofridos, a pensar,

Em ti, sobre o alto mar!

Ai! não sabes que saudade

Padece o nauta ao partir

Sentindo na imensidade

O seu batel a fugir

Incerto do porvir.

Os perigos da tormenta

Não se comparam, querida,

Às dores que experimenta

A alma na dor perdida

Nas ânsias da partida

Adeus, à luz que desmaia

Nos coqueirais ao sol-por!

E bem pertinho da praia

$\mathrm{O}$ albergue, o ninho, amor

Do humilde pescador $[\ldots]^{83}$

Separando as décimas da "Praieira" em grupos de 5 versos, percebemos o mesmo esquema de rimas presente nas últimas 5 linhas da terceira estrofe de "Moda do Corajoso" $(\mathrm{ABABB})$. Além disso, o primeiro verso da "Praieira" lembra o início do poema de Mário de Andrade - "Praieira dos meus amores" é similar a "Maria dos meus pecados" -, semelhança que indica o resgate da musicalidade popular empreendido por Mário de Andrade, em sua $\operatorname{poesia}^{84}$.

O esquema de rimas dos últimos versos da quinta estrofe de "Moda do Corajoso" é também semelhante ao encontrado na modinha "Praieira". No entanto, a penúltima estrofe do poema de Mário de Andrade é cortada por duas linhas que não participam do esquema ABABB - "Faz do desejo em bordão," "E encabulado ponteia".

\footnotetext{
${ }^{82}$ ANDRADE, M $O$ turista aprendiz. Estabelecimento de texto, introdução e notas de Telê Porto Ancona Lopez. Belo Horizonte: Itatiaia, 2002, p 204.

${ }^{83}$ ANDRADE, M. As melodias do boi e outras peças. Preparação, introdução e notas de Oneyda Alvarenga. São Paulo: Duas Cidades; Brasília: Instituto Nacional do Livro, 1987, p 302.

${ }^{84}$ Em anotação feita a lápis por Mário de Andrade, em seu exemplar de Poesias de Gonçalves Dias, ao lado do poema "Sonho de virgem", podemos identificar, também, uma possível matriz do verso-refrão de "Moda do corajoso". O poeta anota, ao lado de "Virgem, virgem de amor, quais são teus sonhos?", verso de Gonçalves Dias sublinhado pelo modernista, a expressão "Rosa, rosa de amor", o que nos leva a pensar em "Maria, viola de amor" (Cf. exemplar de Mário de Andrade: DIAS, G. Poesias de Gonçalves Dias. Nova edição organizada e revista por J. Norberto de Souza Silva. Rio de Janeiro; Paris: Livraria Garnier, (1919?), p 194).
} 
25 Meu espírito sublima

26 O fogo devorador.

27 Faz da paixão uma prima,

28 Faz do desejo um bordão,

29 E encabulado ponteia

30 A malvadeza do amor.

31 Maria, viola de amor!...

Os versos 28 e 29 formam um adendo na melodia que, estendendo-a e adiando sua conclusão, cria novos movimentos melódicos, enriquecendo a estrofe e ajudando a construir, ainda, a ondulação viva do recortado que finaliza a moda.

A musicalidade própria do povo brasileiro, resgatada por Mário de Andrade, revela-se, ainda, por meio do emprego, no primeiro poema de Tempo da Maria, do "alto da moda". Esse processo, recorrente na composição musical popular, é caracterizado pelo poeta, em anotações feitas em capas de discos de sua coleção, como introdução vocal cantada da moda de viola ${ }^{85}$, utilizado, ainda, na finalização das canções caipiras, como podemos conferir no Dicionário musical ${ }^{86}$. No poema de abertura de Tempo da Maria, os dois versos iniciais e a sua retomada, ao final, constituem o "alto da moda". A exemplo da canção Jorginho do sertão, de Cornélio Pires, em que o alto da moda, formado por uma sextilha, é retomado, após uma série de quadras, apenas com quatro versos ${ }^{87}$, o alto da "Moda do corajoso" - "Maria dos meus pecados/ Maria, viola de amor..." - é retomado, ao final do poema, por meio de apenas um verso - "Maria, viola de amor!...”. Dessa forma, a volta à estrofe inicial, na última linha do poema, além de evidenciar a tensão entre opostos que o percorre, ao invocar a figura circular da serpente que morde o próprio rabo, e de aproximá-lo, ainda, da forma de composição dos trovadores, como dito acima, atualiza um recurso típico da música brasileira.

O tom peculiar do verso de fechamento do poema - "Maria, viola de amor!..." -, terminado por meio do timbre grave "o", nota musical que finaliza a moda prolongando-se por meio do "r" surdo final, quase imperceptível, e pelas reticências, é o arremate da cantiga que, ao mesmo tempo em que reitera o último verso da quinta estrofe - "A malvadeza do amor" -, fazendo ressoar a palavra "amor" em uma repetição semelhante às ocorridas no final das sextilhas do poema, nos leva, novamente, ao seu início, em um movimento circular constante, símbolo da desejada união dos contrários.

\footnotetext{
${ }^{85}$ A música popular brasileira na vitrola de Mário de Andrade. Texto pesquisado e comentado por Flávia Camargo Toni. São Paulo: Editora Senac São Paulo, 2004, p 124 e p 145.

${ }^{86}$ ANDRADE, M. Dicionário musical brasileiro. Belo Horizonte: Itatiaia, 1999, p 18.

${ }^{87}$ Cf. A música popular brasileira na vitrola de Mário de Andrade, $\mathrm{p} 85$.
} 
Em "Moda do corajoso", utilizando-se de processos musicais populares, o poeta aproxima-se da alma fragmentada de seu povo. O trovador mestiço, acompanhado pelo instrumento erudito, reconstrói, em seu canto, o tom do cantador brasileiro, expressão racial de um povo plural, anunciando-se, no primeiro poema de Tempo da Maria, como o rapsodo - o tupi tangendo o alaúde - que irá tecer a música do grupo de poemas inspirado pela amada inatingível - a dona ausente. 


\section{DOIS POEMAS DE “TEMPO DA MARIA”}

Em meio aos versos musicais de Tempo da Maria, dois poemas longos chamam a atenção do leitor à medida que se constroem tendo como base a movimentação do eu lírico na paisagem - "Amar sem ser amado, ora pinhões!" e "Louvação da tarde". Antonio Candido insere os poemas de deslocamento de Mário de Andrade na tradição da poesia itinerante, em que o movimento do corpo sugere devaneios ou meditações e em que o tempo narrativo coincide com o tempo narrado. Esse tipo de poesia, inaugurado, de acordo com o estudioso, por Jean-Jacques Rousseau, está presente na obra de românticos de diversos países ${ }^{1}$.

Em "Louvação da tarde", em tom próprio de quem medita, a voz lírica percorre a paisagem rural em um forde, abandonando-se ao ritmo da "maquininha" que regula seu pulso, perdendo-se em devaneios. Por meio de fantasias do poeta, invocadas pelo momento vespertino, "Louvação" constrói-se como um texto de caráter reflexivo. Outro poema de deslocamento, “Amar sem ser amado, ora pinhões!", apesar de não atingir o mesmo tom meditativo de "Louvação da tarde", também é construído ao sabor da viagem do eu poético que percorre, no bonde, as ruas de São Paulo. No segundo poema de Tempo da Maria, ao mesmo tempo em que organiza os versos de acordo com os solavancos do transporte coletivo - mais rápidos, em determinados momentos, e mais lentos, em outros -, o eu lírico se identifica de forma profunda com a paisagem que se abre ao seu olhar, revelando a multiplicidade de seu eu e, ao mesmo tempo, a face contraditória de seu país arlequinal.

O movimento da viagem, cerne da poesia itinerante, é fundamental para Mário de Andrade, já que é o "modo de descobrir o 'outro' [...], [o] modo de descobrir o 'eu”", como afirma Octavio Ianni ${ }^{2}$. Como a procura da identidade nacional, para Mário, está ligada à busca íntima da própria identidade, como nos ensina Lafetá ${ }^{3}$, Mário de Andrade é o viajante por excelência que busca definir a si mesmo e ao outro, descobrindo, na face fragmentada de seu país, seu ser também dilacerado. Em viagens por meio de leituras, em suas andanças pelo país, assim como no trajeto que percorre por meio de sua criação literária, com o olhar pronto para colher nas dobras do caminho a singularidade, enxergando as fissuras e as diferenças que

\footnotetext{
${ }^{1}$ CANDIDO, A. O poeta itinerante. In: O discurso e a cidade. São Paulo: Duas Cidades, 1993, p 260-4.

${ }^{2}$ IANNI, O. Enigmas da modernidade. Rio de janeiro: Civilização Brasileira, 2000, p 13.

${ }^{3}$ LAFETÁ, J. L. Figuração da intimidade. São Paulo: Martins Fontes, 1986, p 8.
} 
se mostram ao seu olhar inquieto, Mário desvela o outro que, paradoxalmente, está delineado nas brechas de sua própria identidade ${ }^{4}$.

\section{Amar sem ser amado, ora pinhões!}

Após ter anunciado, em "Moda do corajoso", a necessidade de sublimar, por meio do canto, o amor pela dona casada, nos moldes das cantigas populares, em que o sentimento pela dona ausente é seqüestrado, o poeta, no segundo poema de Tempo da Maria - "Amar sem ser amado, ora pinhões!" -, entoa seu amor pela mulher proibida.

Ao lado do resgate do tom da fala popular e do emprego de sextilhas, caras à forma da moda, Mário de Andrade emprega, no poema “Amar”, o verso de oito sílabas, "um dos versos mais usados pelos trovadores galego-portugueses, principalmente nas cantigas de caráter cortês" 5 . Dessa forma, o trovador brasileiro, anunciado no primeiro poema de Tempo da Maria, percorre, em "Amar", as ruas de São Paulo, tecendo seu canto por meio da métrica própria dos cantores ambulantes medievais. No entanto, o poeta, ao cantar o amor pela amada, resgatando um tema comum da música popular, percorre a cidade em um bonde, índice de modernidade, unindo, dessa forma, elementos díspares.

Os versos de "Amar" seguem o percurso da viagem do trovador moderno, ao serem traçados de acordo com os movimentos do transporte urbano que dita o ritmo dos devaneios do poeta, constituindo-se, ainda, como uma partitura musical formada por diferentes andamentos. Apesar de ser citada textualmente apenas duas vezes no poema, a viagem do bonde que leva o eu lírico pelas ruas de São Paulo é reconstruída por meio do ritmo dos versos. Partindo de um andamento mais lento, início do deslocamento do veículo elétrico, em um crescendo, o poema atinge momentos em que sua música, mais agitada, revela os solavancos indecisos do transporte coletivo em maior velocidade e, ao mesmo tempo, a perturbação do eu poético que vive o dilema do amor impossível. Aos poucos, em um rallentando, a calma inicial é retomada, sinalizando o término da viagem. $\mathrm{O}$ ritmo final de “Amar sem ser amado, ora pinhões!" remete-nos, portanto, ao seu início, revelando, assim como "Moda do corajoso", a forma cíclica, aproveitada, na música, pelo rondó. A serpente que morde o próprio rabo nos faz pensar, portanto, nos paradoxos que acompanham a obra de Mário de Andrade, marcada pela pluralidade e pela conjugação de opostos.

\footnotetext{
${ }^{4}$ CARDOSO, S. O olhar viajante (do etnólogo). NOVAES, A. (org) O Olhar. São Paulo: Companhia das Letras, s/d, p 360.

${ }^{5}$ CUNHA, C.; CINTRA, L. Nova gramática do português contemporâneo. Rio de Janeiro: Nova Fronteira, 1998, p 665.
} 
Dividindo “Amar sem ser amado, ora pinhões!" em cinco blocos de estrofes, além de uma parte menor que funciona como apêndice à composição poética -a "Louvação do Éter" -, podemos compreender não apenas a modulação dos versos, como também o ritmo que recria o movimento itinerante do poema.

\title{
O poema e seus diferentes andamentos
}

\author{
Amar sem ser amado, ora pinhões! \\ Esperemos neste lugar. \\ Não sou nenhum conde do papa, \\ Só mesmo de Anto serei conde... \\ Sou poeta da viação barata, \\ Mário, pague os duzentos réis... \\ Siga, chofer. Espero o bonde. \\ Cachorro. Trilhos nobres. Moças. \\ Moças, não. Mulheres perdidas \\ No ouro, distinga-se, senão \\ Perde o sal a comparação \\ Com que saudei essas amigas: \\ - Grandes auroras promissoras! \\ Tenho jeito pra gigolô... \\ E, por falar de aurora, enfim \\ Me dá São Paulo uma tardinha \\ De que o poeta Gonçalves Dias \\ Si tivesse alguma saudade, \\ Tinha razão. Que nem rubi. \\ De puro oriente, no ocidente \\ O Solão despenca do mármore \\ Dum céu elegante, na estica. \\ Esta folha no meu chapéu... \\ Em mim, talqual num tronco de árvore, \\ Trepa um ventinho piricica.
}

No início do poema, o poeta nos convida a esperar o bonde a seu lado, levando-nos, assim, a acompanhar a viagem traçada em versos - "Esperemos neste lugar". Além de localizar-se espacialmente - parado, na cidade, à espera do transporte -, o eu lírico nomeia-se: é "Mário", o poeta que, não sendo "conde do papa", título de nobreza dado pela Igreja, se conforma em tomar a "viação barata" e em ser apenas "conde de Anto", nome familiar de António Nobre, poeta português lido por Mário provavelmente a partir de $1914^{6}$. Em seu

\footnotetext{
${ }^{6} \mathrm{Na}$ biblioteca particular de Mário de Andrade, catalogada no IEB, há um exemplar de Só, de 1913, com dedicatória a Mário feita, em 1914, pelo amigo de congregação mariana Aloísio Álvares Cruz, de acordo com Telê (LOPEZ, T. A. A biblioteca de Mário de Andrade: seara e celeiro da criação. In: ZULAR, R. (Org). Criação em processo. São Paulo: Iluminuras, 2002, p 56).
} 
exemplar de Só, Mário de Andrade destaca com dois traços curvos ao lado das estrofes, entre outros poemas, o terceiro soneto de Nobre em que o escritor penumbrista tece considerações sobre o condado construído, na infância, com areia da praia - "O meu condado, o meu condado, sim!/ Porque eu já fui um poderoso conde,/ Naquela idade em que se é conde assim..."7. Ao anunciar-se conde de Anto, a voz lírica invoca, no segundo poema de Tempo da Maria, os versos de Nobre.

$\mathrm{Na}$ segunda estrofe, após dispensar o chofer do carro de aluguel - locomoção particular -, entregando-se ao movimento do transporte coletivo, o eu lírico cadencia seus versos por meio de pontos que interrompem a fluidez do discurso, seguindo o ritmo batido do bonde que começa a andar - "Cachorro. Trilhos nobres. Moças". No início da viagem, o eu poético observa a paisagem, saudando ironicamente personagens da rua: as "mulheres perdidas" - as prostitutas ou amantes - ou as "mulheres perdidas/ no ouro" - damas da sociedade - são "grandes auroras promissoras". O ouro que envolve as moças, fruto do trabalho de perdição ou da posição social, aparece aos olhos do poeta como o brilho do Sol matutino - a aurora -, comparação que o leva à associação com o oposto do amanhecer - o crepúsculo que o cerca -, momento em que cores diferentes se sobrepõem. É estabelecido, portanto, um contraste entre materialismos da vida prosaica e a disposição anímica para contemplar e absorver a expressão da natureza.

A tarde, intersecção de opostos - dia e noite -, é paisagem propícia para o sentimento contraditório do poeta que ama sem poder amar, além de ser o momento do ângelus, canto de louvor à Maria, mãe de Deus, e, por extensão, à Maria, mulher sedutora e santificada. O vermelho forte e vibrante do entardecer, rubi dado ao poeta por Paulicéia, fazendo-o lembrarse do romântico Gonçalves Dias, invade a brancura do dia, assim como a paixão do poeta - o vermelho - contrasta com a brancura santa e sublime da dona inacessível. A amplidão vespertina, de cor intensa, é nomeada com o carinhoso e tímido diminutivo "tardinha", de sabor brasileiro, compondo mais um dos contrastes do poema.

\footnotetext{
E, por falar de aurora, enfim

Me dá São Paulo uma tardinha

De que o poeta Gonçalves Dias

Si tivesse alguma saudade,

Tinha razão. Que nem rubi.
}

A beleza sonora da terceira estrofe é construída por meio do contraste entre o som aberto da maioria das sílabas tônicas, destacadas em itálico acima, e o timbre fechado de

\footnotetext{
${ }^{7}$ NOBRE, A. Só. Publicações Europa-Améria. s/l, s/d, p 127.
} 
algumas sílabas fortes em final de verso - "enfim", "tardinha". Marcadas por nasais, as palavras que finalizam os versos 14 e 15 constroem, ao abaixarem o tom, a sensação de finitude. Em um decrescendo sonoro, os versos terminados no timbre mais fechado dão ao leitor a impressão de esvaecimento que acompanha o pôr-do-sol, intensificada pelo sussurrar das sibilantes dos versos 16 e 17. O vocábulo final "rubi" confirma o esmorecimento melódico ao terminar a estrofe por meio da fraquejante oxítona formada pela vogal "i", ajudando a compor a sensação dada pela tarde que se dispersa.

No primeiro bloco, formado pelas quatro estrofes iniciais, o eu poético começa a viagem de bonde, como vimos, observando a paisagem e sendo tomado pela beleza da tarde. Nesse primeiro momento, início da viagem, os versos são marcados por um ritmo comedido ditado por pontos incisivos que cortam, muitas vezes, o verso ao meio, assim como pelo uso de reticências - "Só mesmo de Anto serei conde...", "Mário, pague os duzentos réis...", "Siga, chofer. Espero o bonde.", “Tenho jeito pra gigolô...”, “Tinha razão. Que nem rubi.”, "Esta folha no meu chapéu...". O andamento calmo do início do poema nos faz lembrar o sacolejar do bonde que, iniciando viagem, começa a tomar velocidade.

Levado pelo balanceio do transporte, o poeta contempla, absorto, o pôr do "Solão" quente, marca da cultura tropical cantada, antes, nos versos de Clã do jabuti ${ }^{8}$. Reconhecendo, na paisagem, a mistura de contrários que também marca seu ser fragmentado - o Oriente no Ocidente -, além de sentir a sensação de esvaecimento e de dispersão da tarde, resgatada pelo tom dos versos das primeiras estrofes, o poeta deixa-se tocar por um dos elementos da natureza - "Esta folha no meu chapéu..." - e, sentindo-se parte da paisagem observada "talqual num tronco de árvore" -, é dispersado pelo "ventinho piricica".

Me perdi pelas sensações.

Não sou eu, sou eus em farrancho,

E vem lavar minha retina,

Em maretas de poeira fina

Todas as coisas tamisando,

O Tâmisa das ilusões.

Me dissolvo por essas águas!

E na vista submarina,

Renovo o milagre cristão

Com a minha multiplicação:

Sou a festança desta vida!

Peixes! Torpedos... bondes... casas...

\footnotetext{
8 "Foi o Sol que/ [...] andou marcando de moreno os brasileiros" (versos de "O poeta come amendoim" (1924), do livro Clã do jabuti).
} 


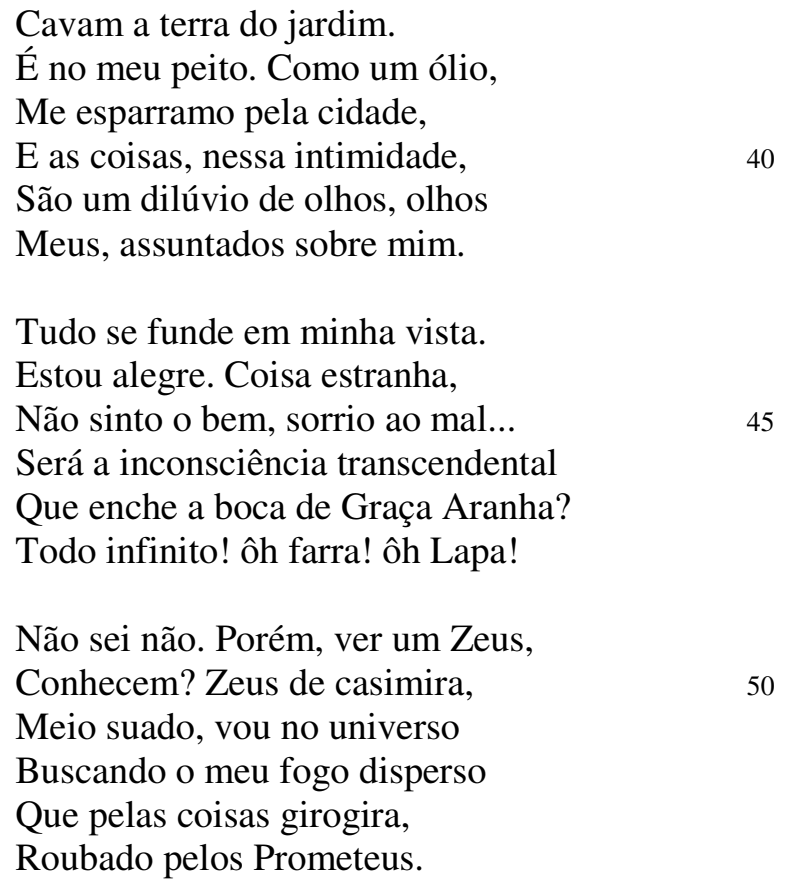

O vento, ao lado da paisagem vespertina e do balanço hipnótico do bonde, faz o poeta se perder por sensações de forma semelhante à dispersão da voz lírica de outro poema de Mário de Andrade ("Toada", do livro A costela do Grã Cão, de 1941), espalhada pelo vento "No outro lado da cidade,/ [...] foi o vento,/ o vento me dispersou". Em "Amar", após o contato com o "ventinho piricica", início da dispersão do eu lírico pela cidade, a viagem do poeta itinerante ganha outra dimensão.

A procura da identidade do Brasil monstruoso e esfacelado, empreendida pelo poeta desde Paulicéia desvairada (1922), desenvolvida também no Losango cáqui (1926) e no Clã do jabuti (1927) e, ao mesmo tempo, a tentativa de compreender o próprio ser múltiplo e complexo, é intensificada no segundo poema de Tempo da Maria, em que a voz lírica assume uma identificação forte com a paisagem que a cerca. O poeta que reconhece, em seu ser, a multiplicidade de seu país, realiza, em "Amar", um contato absoluto com a cidade, ao sentir os elementos exteriores dentro da parte mais íntima de seus olhos, em "sua retina", por meio de paradoxais ondas de poeira fina. Mergulhado nas águas-areias densas do rio Paulicéia, o poeta é multiplicado - "não sou eu, sou eus, em farrancho" - e a paisagem e ele se misturam de tal forma que os elementos externos e a sensibilidade do eu lírico são um só. O eu poético pode, então, sentir em si, de forma profunda, a vida da cidade: pulsa, em seu próprio peito, o ritmo de se cavar um jardim. Fazendo parte do rio Paulicéia, "como um ólio", 
o poeta - líquido - sente as "coisas" externas como seus próprios olhos "assuntados" sobre ele mesmo. 9

Cavam a terra do jardim.

É no meu peito. Como um ólio,

Me esparramo pela cidade,

E as coisas, nessa intimidade,

São um dilúvio de olhos, olhos

Meus, assuntados sobre mim

O "dilúvio de olhos", abundância intensificada pela repetição do plural - "olhos, olhos/ meus" -, encharca o eu lírico que sente os olhares exteriores como se fossem seus próprios olhos multiplicados. Na estrofe em que a identificação entre o poeta e o mundo exterior é revelada dramaticamente pelos olhos que se vêem por meio de olhos alheios, a sonoridade dos versos revela também a sensação de multiplicação e de espelhamento. Em um movimento contrário, os sons finais dos três primeiros versos são repetidos nos três últimos, construindo uma musicalidade formada por sons reduplicados que, organizados de forma simétrica, começam e terminam da mesma maneira - "im", "ólio", "idade" se transformam em seu oposto: "idade", "olhos", “im". A simetria sonora intensifica a sensação de multiplicação e de união de opostos, tema que percorre a obra de Mário de Andrade. Esse esquema rítmico, retomado várias vezes durante o poema, constrói, ainda, a música dos versos que segue o movimento do bonde, como se verá adiante.

No momento de profunda identificação entre o interior do eu lírico e o mundo exterior, o poeta alcança o plano do mito. Os brasileiros são descritos por Mário de Andrade, no "Prefácio interessantíssimo", como "os primitivos de uma nova era", pois o modernista reconhece, no seio de nossa civilização, traços da "mentalidade primitiva" estudada por antropólogos como Levy-Brühl. O primitivo, portanto, buscado pelas vanguardas européias como remanescências afloradas, em certos momentos, no homem civilizado, estava, no Brasil, não apenas em camadas interiores do ser, mas exposto por meio da arte, como nos lembra Telê ${ }^{10}$. Como afirma Alfredo Bosi, os primeiros modernistas entendiam o país como um grande mito que, de acordo com o estudioso, "concilia as contradições que não lhe é dado

\footnotetext{
${ }^{9}$ As águas oleosas em que se transforma o eu lírico de “Amar sem ser amado, ora pinhões!” lembram as águas escuras do rio Tietê, trabalhadas, mais tarde, pelo poeta, em "A meditação sobre o rio Tietê" (escrito entre 30XI-44 e 12-II-45). Neste último poema composto por Mário de Andrade, a realidade exterior também se mistura às águas do rio e o poeta - a lágrima do poeta - dissolve-se no Tietê.
}

${ }^{10}$ LOPEZ, T. P. Mariodeandradiando. São Paulo: HUCITEC, 1996, p 97-8. 
pensar" 11 . O poeta moderno, por meio do resgate, em sua produção erudita, da cultura do povo brasileiro, busca "a poesia das origens, o substrato selvagem de uma "raça", 12, principalmente nos livros de sua fase "heróica", como Clã do jabuti (1927) e Macunaíma (1928). Em “Amar sem ser amado, ora pinhões!”, poema do volume de 1930, a visão do país como um mito que concilia contradições alcança o eu múltiplo do poeta que, ao se entregar ao mundo exterior, realiza uma identificação mitológica: não separando a si mesmo do mundo natural, transfere para os objetos que o cerca as próprias características ${ }^{13}$. Levado por suas observações do fenômeno folclórico brasileiro, assim como pelas teses de Lévy-Brühl, antropólogo francês que, de acordo com Telê, teve grande influência no nosso Modernismo (lido por Mário a partir de 1928) ${ }^{14}$, Mário resgata, no poema, a mentalidade pré-lógica dos primitivos, ao mostrar que "objetos podem ser simultaneamente o que são e algo diferente" 15 .

Como nos esclarece Telê, para Brühl, as representações míticas dos primitivos não são determinadas racionalmente, mas surgem de imperativos e sentimentos coletivos, dominando o indivíduo sem que ele precise pensá-las de forma racional, fazendo-o participar do mundo sem sistematizá-lo ${ }^{16}$. No poema, Mário, recuperando o primitivo que compõe o caráter do povo brasileiro, entrega-se à participação pré-lógica do mundo. No entanto, o espírito racional do modernista não é totalmente suprimido, como veremos adiante.

Os versos de "Amar sem ser amado, ora pinhões!", ao construírem uma identificação forte entre o eu lírico e o mundo que o cerca, além de conjugar opostos - o mundo exterior e o mundo interior - e de mostrar o resgate da cultura popular pelo poeta que reconhece nela os traços de uma mentalidade primitiva, desvelam o novo passo dado por Mário de Andrade em busca da identidade brasileira que, a partir de Remate de males, é procurada por meio de mergulhos no próprio ser do poeta que, como a cidade e o país que o cerca, é também complexo e inapreensível. O movimento da viagem que, de acordo com Octavio Ianni, "ao mesmo tempo que demarca diferenças, singularidades ou alteridades, demarca semelhanças, continuidades, ressonâncias[;] tanto singulariza como universaliza" ${ }^{\text {17 }}$, presente na poesia de Mário de Andrade, leva o eu lírico não apenas a reconhecer as semelhanças e diferenças entre

\footnotetext{
${ }^{11}$ BOSI, A. Moderno e modernista na literatura brasileira. In: Céu, inferno. São Paulo: Duas Cidades; Ed. 34, 2003, p 216.

12 Ibidem, p 217.

${ }^{13}$ MIELIETINSKI, E. M. A poética do mito. Rio de Janeiro: Forense, 1987, p 191.

${ }^{14}$ LOPEZ, T. A. Mário de Andrade: ramais e caminhos. São Paulo: Duas Cidades, 1972, p 92.

${ }^{15}$ MIELIETINSKI, E. M. Op cit, p 45.

${ }^{16}$ LOPEZ, T. A. Op. cit., p 94.

${ }^{17}$ IANNI, O. Op. cit., p 13.
} 
o eu e o outro, mas a revelar a alteridade dentro da continuidade - o outro dentro do eu, o eu dissolvido no outro. A experiência itinerante do eu poético, em "Amar sem ser amado, ora pinhões!”, confirma as idéias de Cardoso: “o 'Outro', só o alcançamos em nós mesmos, o estranho está prefigurado no sentido aberto do nosso próprio mundo". ${ }^{18}$

No bloco de estrofes em que o eu poético se identifica com a paisagem (versos 25 a 54), o movimento mais agitado do poema transparece por meio do uso intenso de exclamações que, ao deixarem pouco espaço para reticências, nos fazem pensar no bonde a tomar velocidade - "Me dissolvo por essas águas!", "Sou a festança desta vida!/ Peixes!", “Todo infinito! ôh farra! ôh Lapa!”. Além disso, é maior a presença de frases mais longas, divididas em vários versos, dando um ritmo mais solto ao período e reconstruindo, ao lado das exclamações, o balançar do bonde que atinge, em meio à viagem, maior rapidez - "Não sou eu, sou eus em farrancho,/ E vem lavar minha retina, / Em maretas de poeira fina/ Todas as coisas tamisando,/ O Tâmisa das ilusões."

As coisas da cidade, derretidas como as águas de um rio, "se fundem" na "vista" do poeta - dentro de seus olhos e, ao mesmo tempo, no horizonte que se abre ao seu olhar -, possibilitando um estado de êxtase quase religioso, uma inconsciência, ou distância, transcendental do bem e do mal que, no entanto, é olhada com reserva e humor pelo eu poético - "Não sei não". O eu lírico torna-se infinito - imenso, inumerável - em sua multiplicação e compara-se a Zeus.

Em sua identificação com a paisagem que o cerca, o poeta se torna a individualização das potências naturais, de forma semelhante aos deuses clássicos que, de acordo com Hegel, são forças naturais e, ao mesmo tempo, indivíduos espirituais que deixam ver, na aparência exterior - em sua forma - a expressão exata de seu conteúdo, revelando, assim, a característica da arte clássica que a aproxima do ideal artístico (união entre conteúdo e forma $)^{19}$. O poeta, ao se comparar com Zeus, se mostra, no poema, como um dos deuses estudados por Hegel - "cada deus, na medida em que traz em si mesmo a determinidade enquanto individualidade divina e, com isso, universal, é em parte caráter determinado, em parte tudo no todo, e paira no centro unificado pleno entre a mera universalidade e a particularidade igualmente abstrata" ${ }^{20}$. É dessa forma, na intensificação de uma multiplicidade contida em uma individualidade, que o poeta desvela seu ser dilacerado.

\footnotetext{
${ }^{18}$ CARDOSO, S. Op. cit., p 360.

${ }^{19}$ HEGEL, G. W. F. Cursos de estética. Vol. II. Tradução de Marco Aurélio Werle, Olivier Tolle. São Paulo: EDUSP, 2000, p 157, 184-5.

${ }^{20}$ Ibidem, p 213.
} 
Apesar de atingir um patamar divino, espécie de preparação para o encontro com a amada, o poeta relativiza sua própria divindade, mostrando-se um Zeus moderno que, com vestuário feito com tecidos de origem européia (a quente casimira), anda "meio suado" atributo humano -, em meio ao calor brasileiro. $\mathrm{O}$ deus-homem percorre o universo realizando a busca essencial: procura o fogo divino - a amada - que, roubado pelos Prometeus, foi disperso pelo mundo.

Às sacudidelas do bonde, 55

$\mathrm{Na}$ minha frente rósea chama

Crepita, ôh pescoço! Um ardor

Principiante, consolador,

Zeus (Zeus sou eu) gemendo chama:

- Fogo, onde estás, aonde? aonde?

É isso! Rapazes, encontrei

O fogaréu maravilhoso

Que foi, que é meu, que será sempre

Meu! Relumeia à minha frente,

E devora num instantinho

As minhas paus Tábuas da Lei.

Moralidade, lei seca, vá-se

Embora! Vá por Seca e Meca!

Darei Seca, Meca e Baía

Por mais este amor, sim, mais um,

Porque enfim é amante de poeta

Toda e qualquer mulher que passe!

Êxtase! Desejo! Loucura!

Quase dolorosa surpresa!

Espanto de não ser mais só!

E a gente imagina que é o pó

Que sufoca e, vai, com aspereza

Bota a culpa na Prefeitura.

O fogo procurado por Zeus-poeta - a mulher amada - só pôde ser divisado após a entrega mítica do eu lírico à paisagem de Paulicéia e após a elevação do eu poético a um patamar divino, preparação que revela a sublimidade da chama rósea, mulher que só pode ser adorada por um ser supremo.

A chama, símbolo de santidade, revela uma mulher intocável, acima das coisas mundanas e, no entanto, invoca também a ardência da paixão. A contradição do fogo - pureza e desejo - aparece ainda na cor rosada de Maria, mistura de vermelho e branco, revelando uma dona ao mesmo tempo sensual e santa. Os solavancos do bonde fazem a labareda-mulher "crepitar" - verbo que faz lembrar, por meio de sua sonoridade, os estalos causados pelo 
fogaréu -, atraindo (chamando) o poeta-deus que sente, em si, o ardor da paixão e, longe de uma postura divina, desejando o corpo sensual da amada - "ôh pescoço!" -, busca, em meio a gemidos, o fogo perdido. O brilho intenso da chama a relumear destrói, com seu ardor, os chatos - "paus" - mandamentos morais, mandados "passear" por outras terras - "por Seca e Meca" 21.

O encontro de Zeus-poeta com o fogo-Maria é descrito como momento intenso de "êxtase", "desejo", "loucura" e de "quase dolorosa surpresa". O êxtase do eu lírico ao ver a mulher sublime - santa inatingível - é similar ao sentimento indizível de alegria e angústia que toma os fiéis durante delírios místicos.

As quatro estrofes em que o poeta se entrega à paixão desenfreada (versos 55 a 78), mostrando-se como um deus sem compostura que implora por um amor destruidor e, paradoxalmente, santificado, são compostas em um tom exagerado e pedante que, ao lado do ritmo mais agitado, formado por inúmeras exclamações e livre de reticências, as contrapõe às tonalidades e movimentos anteriores do poema. Nesse momento, o êxtase toma o poeta embalado pelo balanço agitado do bonde, mais veloz em meio à viagem - "Êxtase! Desejo! Loucura!/ Quase dolorosa surpresa!/ Espanto de não ser mais só!”. No entanto, o amor grandioso cantado de forma afetada pelo poeta sofre, ainda nessa parte do poema, rebaixamentos que, tirando-o da elevação suprema a que fora alçado, começam a mostrá-lo mais próximo da realidade prosaica: o grande amor é apenas mais uma paixão, "porque enfim é amante de poeta/ toda e qualquer mulher que passe!", assim como a falta de ar do poeta tomado pelo arrebatamento do desejo pode ser apenas o pó sufocante das ruas "e, vai, com aspereza,/ bota a culpa na Prefeitura."

No quarto bloco (versos 79 a 103), o tom desajeitado do poeta modernista que sucumbe ao arrebatamento místico é quebrado, iniciando-se um balanceio indeciso entre a atração do grande amor e o comedimento de quem conhece a impossibilidade de realizá-lo, invocando, no poema, o balanço do bonde que, em ritmo forte de viagem, joga os passageiros de um lado para outro. Após a identificação mitológica e pré-lógica com o mundo natural, o eu lírico sente-se abalar por constatações racionais que quebram o encanto mítico.

Minha paixão de sopetão!

Já nem posso mais respirar!

Que pescoço! que braços! quê!...

Bom... olhemos a natureza.

O céu se encurva sobre o chão

Num gesto forte de abraçar.

\footnotetext{
21 "Ceca", vocábulo originado do árabe "caminho", tomado como lugar, é oferecido, ao lado de "Meca" e "Baía", em uma justaposição de terras estrangeiras e brasileiras, como preço pago pelo amor sentido por Maria.
} 
Te amo!... Que bonita que ela é!...

Trago comigo o cheiro dela,

Só penso nela!... Infelizmente

$\mathrm{O}$ meu caso não tem futuro,

Ai, Maria do perfil duro,

Ai, Maria sempre presente!...

Que friúme em minha tristeza...

Rapazes! A minha alegria,

A minha alegria está presa

Num perfil duro de mulher!

Ela me olha tão fria, fria...

Ora! verifiquemos como

Rictus: "Merde! voilá l’hiver."

Poeta, sossegue, ela é casada...

Pois sim. Pensemos noutra coisa.

No que será?... Negro de suéter,

Que engraçado!... mas... que tristeza!

Esta vida não vale nada!...

Vou cantar a Louvação do Éter!

No momento em que está se entregando ao arrebatamento amoroso, envolvido pela beleza física da mulher - "Que pescoço! que braços! quê!..." -, o poeta tenta conter o desajeitado tom romântico, ao voltar seu olhar para a natureza, como se desejasse retornar ao ritmo do início do poema, em que, calmo, divisava, ao longe, as cores da tarde - "Bom... olhemos a natureza". Os versos "o céu se encurva sobre o chão/ num gesto forte de abraçar" revelam, por meio do tom comedido, sem exclamações, marcado por uma acentuação que segue, nas duas linhas, o mesmo padrão (as segundas, quartas e oitavas sílabas métricas são acentuadas), a tentativa do eu lírico em restituir a calma a seu poema, retomando seu equilíbrio. No entanto, a tentativa é frustrada, pois a imagem do entardecer invoca o abraço amoroso de opostos - o céu e a terra -, fazendo o eu poético entregar-se, novamente, ao desejo por Maria - "Te amo!... Que bonita que ela é!...”.

O resgate do verso de "Moda do corajoso" - "Que bonita que ela é!" - acompanha a retomada, em "Amar", do dilema vivido pelo eu lírico no primeiro poema de Tempo da Maria: apesar de enamorado, no presente, pela mulher sublime, afirma que irá esquecê-la, no futuro. Recriando o balançar indeciso do bonde que ginga em meio à viagem, os versos de “Amar" alternam-se entre a lucidez do poeta que pensa ser impossível realizar o desejo amoroso, consciente de que esse amor será esquecido no futuro - "O meu caso não tem futuro" -, e a fatalidade do amor que o toma no tempo presente - "Ai, Maria sempre presente!...", alternância realçada pela pontuação que oscila entre exclamações e reticências. 
A volta do dilema de "Moda do corajoso" aparece em substituição à certeza proclamada pelo eu poético, no terceiro bloco de estrofes de "Amar", de que o desejo por Maria é eterno - "foi, [...] é meu, [...] será sempre,/ meu".

Ao constatar a impossibilidade de realização amorosa - "Poeta, sossegue, ela é casada..." -, o eu lírico tenta escapar de seu desalento, procurando direcionar, racionalmente, seus pensamentos - "Pensemos noutra coisa./ No que será?... Negro de suéter,/ Que engraçado!... mas... que tristeza!”. No entanto, apesar da graça achada na sobreposição desengonçada do descendente africano ao suéter inglês, interrupção do tom melancólico que se desenvolvia no poema, a tristeza fatal atinge o poeta que, certo de que somente no futuro poderá esquecer Maria, sofre, no presente, a indiferença da mulher inalcançável.

As quebras realizadas no poema pelo eu lírico preocupado em não se entregar ao tom exagerado do amor não correspondido, intercalando arroubos românticos a certezas racionais de que esquecerá, no futuro, a amada, assim como lançando mão do humor para tentar esquecer o sofrimento, são semelhantes a certas passagens do livro $O$ turista aprendiz $^{22}$. No diário de viagem, o poeta itinerante, ao se aproximar do sublime - das companheiras de viagem proibidas ao desejo; da grandeza da Foz do Amazonas; da aurora vista a partir do vapor que corta as águas do rio $^{23}$-, percebendo, nesses momentos, o caráter elevado e quase metafísico de seu discurso, quebra o alumbramento por meio de constatações prosaicas ou por meio de brincadeiras, como bem mostrou Telê Ancona Lopez em seu curso sobre as dimensões de $O$ turista aprendiz ${ }^{24}$. Em “Amar sem ser amado, ora pinhões!”, ao aproximarse da mulher sublime, entregando-se ao tom exaltado de seus versos, o poeta também rompe o discurso elevado, voltando-se à realidade prosaica. A alternância entre o arrebatamento amoroso e a racionalidade sensata dá ao poema a sensação de intermitência conseguida por meio de sucessivos cortes.

O título do poema, “Amar sem ser amado, ora pinhões!”, também mostra a alternância entre o sentimento arrebatador que toma o poeta e a preocupação do modernista em fugir do tom pedante e apaixonado, pois ao lado da expressão utilizada por Mário de Andrade, em

\footnotetext{
${ }^{22}$ Em 1927 e em 1928, Mário de Andrade dirige-se ao Norte e ao Nordeste do país, conferindo, em meio ao povo brasileiro, a imagem de Brasil construída por ele, antes, por meio de leituras, anotando seu deslumbre frente ao esplendor amazônico e registrando, como pesquisador aplicado, as diversas formas de manifestação popular, anotações reunidas, depois, em O turista aprendiz, livro organizado por Telê Ancona Lopez.

23 ANDRADE, M. O turista aprendiz. Estabelecimento de texto, introdução e notas de Telê Porto Ancona Lopez. Belo Horizonte: Itatiaia, 2002, p 54, 59 e 122-124.

${ }^{24}$ A disciplina "O Turista Aprendiz: Dimensões de um Diário de Viagem” foi ministrada pela Prof ${ }^{\mathrm{a}}$. Dr ${ }^{\mathrm{a}}$. Telê Porto Ancona Lopez, na Faculdade de Filosofia Letras e Ciências Humanas da USP, no segundo semestre de 2005.
} 
"Amor e medo", texto de 1935, para definir um dos temas românticos do medo do amor - "o tema do "amar sem ser amado", 25 -, o prosaico "ora pinhões!" mostra o enfado ou a reprovação do modernista, feita em chave humorística, ao próprio medo de $\operatorname{amar}^{26}$.

Se, nos versos de entrega total à paixão, a mulher é representada pela chama que desenha movimentos crepitantes embalada pelo bonde, a partir do reconhecimento da impossibilidade de realização amorosa, o poeta passa a ver na amada o perfil duro e frio. A figura inexorável de Maria prende em seu ser austero, resistente a qualquer aproximação, a alegria do eu lírico que, sem outra opção, se entrega à tristeza gelada trazida pelo olhar distante da amada - "que friúme em minha tristeza". A proximidade da frieza da mulher branca, inatingível como as donas ausentes européias desejadas pelos marujos portugueses, faz o poeta sentir, em meio ao calor brasileiro, as agruras do inverno europeu, verificando, como o poeta francês Jehan-Rictus, a aspereza da estação gelada - "Merd'! V'là l'Hiver et ses dur'tés"27. A dona fria de "Amar sem ser amado, ora pinhões!" é, de certa forma, semelhante à "mulher-anjo-homem assexuado" que aparece em sonho a Macário, uma das representações do medo de amor na obra de Álvares de Azevedo, como lembra Mário de Andrade - "Era um anjo. Há cinco mil anos que ela tem o corpo da mulher e o anátema duma virgindade eterna. Tem todas as sedes, todos os apetites lascivos, mas não pode amar. Todos aqueles em que ela toca se gelam" 28 .

Para descansar do embate desgastante entre o desejo amoroso e a certeza de não poder realizá-lo, o eu poético entoa a "Louvação do Éter", apêndice formado por duas estrofes destacadas dos outros versos por recuo esquerdo. De acordo com Mário de Andrade, em seu Dicionário musical brasileiro, a "louvação", conhecida, no nordeste, como "Loa", é, entre outras coisas, um trecho de poesia intercalado entre os números de canto de reisados, autos e outros brinquedos, permitindo o descanso entre as danças ${ }^{29}$.

\footnotetext{
${ }^{25}$ ANDRADE, M. Amor e medo. In Aspectos da Literatura Brasileira. Editora Itatiaia: Belo Horizonte, 2002, p 230 .

${ }^{26}$ A expressão "amar sem ser amado" aparece também em quadras populares, como podemos ver em uma das "Peças para a 'Dona ausente", colhidas por Mário de Andrade - "De amá sem ser-amado/ É a peió coisa do mundo" (ANDRADE, M. As melodias do boi e outras peças. Preparação, introdução e notas de Oneyda Alvarenga. São Paulo: Duas Cidades; Brasília: Instituto Nacional do Livro, 1987, p 290).

${ }^{27}$ RICTUS, J. Les soliloques du pauvre. Pierre Seghers, éditeur: Paris, 1955, p 9.

${ }^{28}$ ANDRADE, M. Amor e medo. In Aspectos da Literatura Brasileira. Editora Itatiaia: Belo Horizonte, 2002, p 252.

${ }^{29}$ ANDRADE, M. Dicionário musical brasileiro. Coordenação de Oneyda Alvarenga, 1982-84, e de Flávia Camargo Toni, 1984-89. Belo Horizonte: Itatiaia, 1999, p 287-8.
} 
Vaga hipótese sem perigo!

Hangar da nossa segurança!

105

Luz de Einstein et caterva! Prova

Dos nove da sabença humana!

Deus, que a cosmogonia nova

Nunca viu, mas conta contigo!

Obra-prima do nosso Amigo!

110

De alguma entocaiada parte

Aonde a ciência não entrou,

Me dás a honra de ser, e eu sou,

Por tuas artes, Malazarte,

Vaga hipótese sem perigo...

O recitador de "Loa" "a diz andando mais ou menos rapidamente dum lado pra outro, em voz monótona, sem nenhuma expressão, puro movimento de memória vocal sem participação quase nenhuma de controle intelectual" ${ }^{30}$. Como o menestrel popular, o poeta de "Amar" repete, sem controle racional, expressões que figuram como retalhos retirados de outros textos, sobrepostos aleatoriamente nos versos, usados para louvar o éter e, ao mesmo tempo, para defini-lo - "hangar da nossa segurança", "prova dos nove da sabença", "Luz de Einstein et caterva", “cosmogonia”, “obra-prima". No entanto, a "Louvação do éter”, principalmente em sua primeira estrofe, é, ao contrário das "Loas" populares, intensificada por exclamações, lembrando, ainda, por meio de frases nominais com ar de abstração, o tom de poemas simbolistas.

A estranha falta de preocupação em realizar um discurso conexo, nesse período, além de nos remeter ao cantador de "Loas", revela o eu lírico submetido aos efeitos anestesiantes do éter, tentando escapar do dilema estabelecido pela necessidade de entrega mítica à amada e pela reflexão racional que aponta, a todo momento, a impossibilidade da realização amorosa e o futuro esquecimento da dona inacessível. No entanto, a solução encontrada pelo poeta para seus dilemas - a entrega à substância inebriante - traz também uma forma de contradição, pois o éter é apresentado, no poema, de forma dúbia: ao mesmo tempo em que é resultado do avanço científico do homem - da "sabença humana" - é também produto místico oriundo de uma fonte divina - "do nosso Amigo" -, capaz de transformar o poeta em "vaga hipótese sem perigo", dando a ele suas características entorpecentes, em uma identificação mítica. A contradição entre dois opostos, o racional e o desejo de entrega mística à amada, vivida pelo poeta e retomada na definição de éter, é realçada pela forma cíclica da louvação que retoma, ao final, o primeiro verso - "vaga hipótese sem perigo".

\footnotetext{
${ }^{30}$ Ibidem, p 288.
} 
No último bloco de estrofes, apesar de mostrar a constância do desejo que não o deixa - "Eu não agüento mais meu peito!" -, o eu poético, talvez influenciado pelos eflúvios calmantes do éter, retoma o tom mais comedido do início, sinalizando o final da viagem de bonde.

Tudo isso há-de passar, Maria,

Durma em sossego. O meu respeito

Sempre há-de respeitar você.

Eu não agüento mais meu peito!

Mas jamais não aceitaria

Arranjos como o de Musset!

Durma sem medo, sossegada.

Você não vai pra sala grande,

Tem sala à parte em meu harém.

Vista o pijama dos meus olhos,

E descanse sobre o meu sonho

Que nunca fez mal pra ninguém!

Eu velarei a corajosa

Dormindo sobre a dinamite...

Fumos... Assombrações... Não te

Largo mais, Iara do Tietê!...

Ao menos até que fareje

Alguma paixonite nova...

É o fim. Lá fora dormirá

Paulicéia. Paz. Quase informe,

Ela dorme, dorme sorrindo,

Enquanto gemo o verso lindo

Com que as índias parecis dormem...

Uirô, mococê ce-macá...

Dirigindo-se a Maria, o eu lírico tranqüiliza a amada com a certeza de que, no futuro, "tudo isso há-de passar". Apesar da força da paixão que o toma, o respeito do poeta, sua moral, mesmo tendo sido descartada nos momentos de arroubo do poema - "moralidade [...] vá-se/ embora" -, é a garantia de que Maria não precisa temê-lo. Arranjos amorosos como o de Alfred de Musset, o jovem e atraente romântico francês, com a ousada poeta George Sand, mulher que abandonara o lar, entregando-se a amores intensos ${ }^{31}$, não são aceitos pelo poeta católico.

Mário, não cedendo ao amor por Maria, foge de sofrimentos decorrentes da entrega amorosa, tais como os vivenciados por Musset que, após o período de ventura com Sand,

\footnotetext{
${ }^{31}$ Cf. FEUGÈRE, A. Un grand amour romantique. Paris: Boivin e cie, Editeurs, 1927.
} 
sofre com a traição da amada, assim como, inconformado, vê a formação de um triângulo amoroso entre ele, Sand e o médico Pagello, relação tríplice evitada pelo poeta de "Amar" que não se entrega a uma dona casada. Não podemos nos esquecer da ligação maternal entre Sand e o jovem Musset, confirmada, depois do rompimento, por cartas da poeta - "eu o amava [a Pagello] como um pai e você [Musset] era nossa criança" ${ }^{32}$. A relação amorosa com a figura materna é evitada, a todo custo, em "Amar sem ser amado, ora pinhões!", pelo poeta que sublima o amor por Maria, mulher que, por meio do nome santo, invoca as virtudes da mãe de Deus, afirmando-se, dessa forma, como figura maternal.

Ao negar "arranjos como o de Musset", o modernista, além de repudiar relações amorosas não aceitas pela moral católica, mostra também a negação ao sentimentalismo do poeta francês que marcou um século inteiro, como afirma Carpeaux ${ }^{33}$. A disposição em fugir aos arroubos românticos aparece claramente, nos versos de Mário de Andrade, por meio de cortes que interrompem os momentos de êxtase amoroso, como se o eu lírico temesse sucumbir a eles. No entanto, no poema moderno, o poeta não apenas foge de arrebatamentos sensuais, mas os usa programaticamente, ao construir o jogo entre clareza racional e entregas amorosas, prevendo as quebras do poema que formam seu eixo temático e construtivo.

A retomada de um tema caro aos românticos - o medo de amar - ajuda o poeta a construir o jogo do poema moderno. Como Álvares de Azevedo, que sublima o medo do amor por meio da relação com a mulher adormecida, o poeta modernista também escapa do temor de se entregar a uma paixão ao desejar a amada que dorme, já que acalenta Maria, ao final do poema - "Durma em sossego./ Durma sem medo, sossegada./ E descanse sobre o meu sonho". Vale a pena transcrever o trecho em que Mário de Andrade discorre sobre a presença da imagem da dona adormecida na obra de Álvares de Azevedo como forma de escapar do amor, assim como aponta a inspiração do poeta brasileiro em versos de Alfred de Musset.

Porém a mais bonita e mais medrosa criação que Álvares de Azevedo inventa, nesse desvio do amor e medo pro dormir no amor [...] está [...] na imagem da amante dormida. Que libertação! O poeta pode gozar o seu amor, junto com a amada e ao mesmo tempo sozinho, fugido dos pavores que o perseguem. Muito provavelmente Álvares de Azevedo encontrou a imagem em Musset. É certo que Rolla causara impressão enorme no paulista. Fez do

\footnotetext{
32 Ibidem, p 116 (Tradução livre do francês).

${ }^{33}$ CAPEAUX, O. M. História da Literatura Ocidental. Vol . IV - O Romantismo. Edições O Cruzeiro: Rio de Janeiro, 1962, p 1909-1913.
} 
poema dele um estudo crítico; traduziu em verso algumas passagens dele, e justamente a em que Rolla encontra Marion dormida ${ }^{34}$.

Assim como Azevedo, no poema "Idéias íntimas", repensa criticamente o seu próprio romantismo, reconhecendo a dor de realizar desejos amorosos apenas por meio de momentos de evasão ${ }^{35}$, retomando, no entanto, ao final de seus versos, novamente o devaneio em que a amada estende para ele seus braços, Mário, após se entregar ao arroubo romântico e reconhecer o impasse dado pelo desejo irrealizável, criando, no poema, quebras que traduzem o enfrentamento de desejos sensuais e da racionalidade, termina seus versos se entregando à amante que dorme sobre seu sonho. Apesar de evitar "arranjos como o de Musset", o modernista se entrega a um dos "arranjos" do poeta francês retomado pelo romântico brasileiro: deseja a amada adormecida, tentando fugir, paradoxalmente, do desejo romântico por meio de uma escapatória também romântica, atualizada, no entanto, pela reflexão modernista: frente à mulher entregue ao sono, realiza e não realiza o seu amor.

O poeta, retomando a identificação mítica com as coisas da cidade, assumindo serem os elementos externos o seu próprio olhar, oferece, no último bloco de estrofes, seus olhos os pijamas - para aquecer o sono da amada, assim como seu sonho - o sossego do leito e, ao mesmo tempo, a explosão da dinamite - para receber o sono de Maria. A mulher adormecida é possuída por meio do abraço do eu lírico, realizado, de forma sublimada, por meio dos elementos da cidade que, sendo também o poeta, envolvem a dona ausente. Identificar-se com objetos que tocam a mulher desejada é recurso semelhante ao empregado pelo cantador popular, em quadra divulgada por Sílvio Romero: "Lá d'outro lado do rio/ Está uma rosa por se abrir;/ Quem me dera ser sereno,/ Para na rosa cair!" ${ }^{36}$. A amada, no poema de Mário de Andrade, é a chama rósea que atrai o poeta, sendo possível tocá-la apenas por meio da identificação com elementos externos que a envolvem, assim como o cantador popular toca a rosa que, do outro lado do rio, só pode ser alcançada por meio do sereno.

\footnotetext{
${ }^{34}$ ANDRADE, M. Amor e medo. In Aspectos da Literatura Brasileira. Editora Itatiaia: Belo Horizonte, 2002, p 248.

35 "E quando a fada/ Que diviniza meu pensar ardente/ Um instante em seus braços me descansa/ E roça a medo em meus ardentes lábios/ Um beijo que de amor me turva os olhos/ [...] Um espírito negro me desperta,/ O encanto do meu sonho se evapora/ E das nuvens de Nácar da ventura/ Rolo tremendo à solidão da vida!" (AZEVEDO, A. Lira dos vinte anos. In: Obra completa: volume único. Organização de Alexei Bueno. Rio de Janeiro: Nova Aguilar, 2000, p 207.)

${ }^{36}$ ROMERO, S. Cantos populares do Brasil. Rio de janeiro: Livraria Francisco Alves, 1897, p 329 (exemplar de Mário de Andrade com a anotação a lápis "seqüestro" ao lado do trecho transcrito).
} 
Fumos... Assombrações... Não te

Largo mais, Iara do Tietê!...

Ao menos até que fareje

Alguma paixonite nova...

Além de assumir a forma da chama rósea, Maria é comparada, no poema, à Iara, um dos "símbolos" do complexo da dona ausente. Mário de Andrade, baseando-se em conceito de Charles Baudoin (Psychanalyse de l'art, 1929), define "símbolo" como uma representação complexa, formada por um feixe de noções ${ }^{37}$. Dessa maneira, em uma sobreposição de conceitos, o mito da Iara, além de representar a mulher desejada e inatingível - a dona ausente -, invoca também a imagem materna, como fica claro em texto de Arthur Ramos, de 1932, apontado, em anotações de Mário de Andrade, como um dos documentos sobre seqüestro.

A mãe d'água (yara, sereia, Yemanjá) é evidentemente a imago materna. [...] O feitiço da Yara [...] nada mais exprime do que o desejo inconsciente de volta ao regaço materno. Mas, como no inconsciente o incesto é tabu, é punido terrivelmente com a morte, ai daquele, que se deixar iludir pela atração fatal da mãe d'água! $!^{38}$

Em meio a fumaças - fumos -, ambiente propício para o aparecimento de entes maravilhosos - assombrações -, Maria, a Iara do rio paulistano, mesmo dormindo sobre o sonho do poeta, atrai o eu lírico de forma irresistível. No entanto, o desejo edipiniano de retorno ao seio materno, manifestado pela atração do poeta por Maria-Iara, apesar de constante, é racionalmente reprimido pela voz lírica de "Amar", que evita arranjos como os de Musset ao recusar a entrega à figura maternal da dona casada e mãe de quatro filhos ("Tem marido, quatro filhos" ${ }^{39}$ ), aceitando a realização da paixão somente por meio do recurso romântico: realiza o amor, de forma sublimada, enquanto a amada dorme.

A Iara aparece também no diário de viagem $O$ turista aprendiz, texto de Mário de Andrade formado por sobreposições de criações literárias ao registro do cotidiano. No diário, ao ser "avistada" pelo poeta, em sua viagem pelo Amazonas, a Iara, possuindo as mesmas características físicas da amada de "Amar sem ser amado, ora pinhões!", é comparada à Maria.

\footnotetext{
${ }^{37}$ ANDRADE, M. Sereia (Manuscrito). In: CARVALHO, R. S. Edição genética d'O seqüestro da dona ausente de Mário de Andrade. Dissertação de Mestrado apresentada ao Departamento de Letras Clássicas e Vernáculas. FFLCH - USP. São Paulo, 2001, p 147.

${ }^{38}$ RAMOS, A. Notas de etimologia. Bahia, Escola de Aprendizes Artífices, 1932. Separata de Bahia Médica, Salvador, no 15/16, 1932, p 1-23. (Bibliografia e texto citados por Carvalho, R. S. Op. cit., p 157).

${ }^{39}$ Versos do último poema de Tempo da Maria - "Maria".
} 
Consegui avistar a Iara. Surgiu de sopetão das águas, luminosa, meio corpo fora, tomando bem cuidado em não mostrar pra mim a parte peixe do corpo. É realmente muito bonita, meio parecida com uma certa malvada que andou, faz pouco, enchendo os meus descansos em São Paulo. Tem o perfil um pouco duro, cabelo preto e bem aparadinho. O carmim da boca é nitidamente recortado. O canto dela é efetivamente mavioso, num ritmo balanceado mas sem síncopas. ${ }^{40}$

Como a Iara do Turista Aprendiz, a Uiara que atrai Macunaíma é também inspirada em Maria, dona marcada pela fatalidade da mulher-peixe - "uma cunhã lindíssima, alvinha [...] que-nem a cara do dia e feito o dia que vive cercado de noite, ela enrolava a cara nos cabelos curtos negros [...]. Tinha no perfil duro um narizinho tão mimoso que nem servia pra respirar" 41.

Macunaíma, em seu retorno ao Uraricoera, não resistindo aos encantos da Uiara, sucumbe à vingança de Vei, tendo o corpo mutilado e perdendo seus tesouros, entre eles, a muiraquitã, a muito custo recuperada. De acordo com Gilda de Mello e Souza, as filhas de Vei - filhas do Sol -, representação das civilizações tropicais morenas, foram recusadas pelo herói que preferiu se entregar à mulher portuguesa, fruto da Europa. Não resistindo aos encantos da Uiara, o herói é punido por sua escolha desastrada por meio da qual mostra um acomodamento aos valores europeus, negando a sua identidade tropical e perdendo, por isso, o símbolo dessa identidade - a muiraquitã ${ }^{42}$. Pensando na semelhança entre a Uiara de Macunaíma e a amada de Tempo da Maria, pode-se compreender, de forma mais completa, o temor que toma o poeta apaixonado de "Amar sem ser amado, ora pinhões!", que evita se entregar ao sentimento amoroso pela dona de traços europeus, representante de uma cultura diferente daquela que pretendia resgatar por meio de seus versos - a cultura tropical e mestiça do Brasil.

No último bloco de versos, em que o poeta acalanta Maria, a Iara do Tietê, o andamento calmo inicial é retomado aos poucos. Abandonando as exclamações, presentes ainda nas duas primeiras estrofes do último bloco, os versos voltam a assumir um ritmo mais comedido, marcado por reticências e por pausas (pontos) - "Dormindo sobre a dinamite...", “Fumos... Assombrações... Não te/ Largo mais, Iara do Tietê!...”, "É o fim. Lá fora dormirá/ Paulicéia. Paz. Quase informe”, “Com que as índias parecis dormem.../ Uirô, mococê cemacá...”.

\footnotetext{
${ }^{40}$ ANDRADE, M. O turista aprendiz. Estabelecimento de texto, introdução e notas de Telê Porto Ancona Lopez. Belo Horizonte: Itatiaia, 2002, p 116.

${ }^{41}$ ANDRADE, M. Macunaíma. Belo Horizonte, Rio de Janeiro: Livraria Garnier, 2000, p 155.

${ }^{42}$ SOUZA, G. M. O tupi e o alaúde. São Paulo: Duas Cidades, 1979, p 62-3.
} 
É o fim. Lá fora dormirá

Paulicéia. Paz. Quase informe,

Ela dorme, dorme sorrindo,

Enquanto gemo o verso lindo

Com que as indias parecis dormem...

Uirô, mococê cê-macá...

O timbre das vogais tônicas da última estrofe do poema, marcadas em itálico acima, dá sonoridade singular ao período, construído por meio do jogo entre vogais abertas e o tom fechado de nasais. Iniciada por uma sílaba marcada pela nasal - "fim" -, a última estrofe desenvolve sua sonoridade por meio da riqueza musical de tônicas abertas - "fora", “dormirâ", "Paulicéia", "paz”, "informe”, “dorme”. Após sustentar o "ó” aberto por meio de repetições de palavras e de sons - "informe/ Ela dorme, dorme" -, nota musical que se sustém, o período repleto de vogais abertas é abruptamente finalizado pela nasal do vocábulo "sorrindo", em um abaixamento de tom. O contraste súbito entre diferentes tons acentua a sensação de fechamento sonoro, invocando o sentimento íntimo e comovido do eu lírico que acalanta a mulher amada. A nasal é mantida, ainda, nos versos seguintes - "lindo", "índias" -, como se a sonoridade da nota musical "in" se estendesse, confrontando-se, ainda, com a retomada da vogal aberta "ór" - "sorrindo,/ Enquanto gemo o verso lindo/ Com que as índias parecis dormem...". O último verso do poema, resgatando a sonoridade singular da fala indígena dos parecis, mais expressivo na medida em que, em uma primeira leitura, aparece sem significado para o leitor, que atenta apenas para sua musicalidade, constituindo-se, assim, como uma verdadeira frase musical, termina o poema em um espraiamento sonoro: as vogais fechadas - "Uirô, mococê" - são finalizadas pelo alastrado "a" - "macá...", música que embala o sono da amada, assim como de Paulicéia.

Roquette-Pinto, em seu livro Rondônia, registrou o acalanto dos índios parecis, resgatado, em verso, por Mário de Andrade:

Fomos, alta noite, visitar a cabana [...]. Numa rede, uma família inteira ressonava [...]. Mais além, uma criança choramingava, ao lado de uma índia moça que a balouçava nos braços cantando: [...]

Uirô-môkôcê ce-maká...

(Menina dorme na rede.... ${ }^{43}$.

\footnotetext{
${ }^{43}$ ROQUETTE-PINTO, E. Rondônia. $6^{\text {a }}$ ed. São Paulo: Editora Nacional; Brasília: INL, 1975, p 92. (A obra veio a público, nos Arquivos do Museu Nacional, em 1917, de acordo com informações na orelha do exemplar).

Na biblioteca de Mário de Andrade, no IEB, há um exemplar de Rondônia, de 1935, sem anotações.
} 
Ao resgatar a sonoridade da língua dos índios parecis - "Uirô, mococê cê-macá..." -, o poeta completa seu acalanto, cantiga terna usada, em todo o Brasil, para adormecer crianças ${ }^{44}$, realizando, assim, o amor sublimado: embala o sono da amada ${ }^{45}$.

Ao final de "Amar sem ser amado, ora pinhões!", o eu lírico volta seu olhar para a paisagem de Paulicéia, como no início do poema, encontrando-a, no entanto, adormecida e "quase informe", como se o canto do poeta, ao acalentar Maria, embalasse também o sono da cidade. Nas últimas estrofes, o eu lírico retoma o andamento calmo dos versos iniciais, sinal do final da viagem de bonde, invocando, ainda, o esmorecimento da tarde e a chegada da noite - "Lá fora dormirá/ Paulicéia" - e, ao mesmo tempo, deixando transparecer o tom do poeta que embala o sono da amada, desejando-a adormecida. É o final do canto de louvação à Maria, conclusão das "ave-marias" entoadas, ao entardecer, em louvor à mulher sensual e santa.

Como pudemos notar, o poema é composto por diferentes andamentos e tons que invocam o percurso do bonde, formando, ao mesmo tempo, uma partitura de versos dividida em partes distintas. Dessa forma, o movimento itinerante da composição poética, desenhado de acordo com o andar do transporte coletivo por São Paulo, assim como pela viagem interior do eu lírico que vivencia, após a identificação mítica com a paisagem urbana, a paixão romântica marcada pelo medo do amor, constroem a música de "Amar sem ser amado, ora pinhões!’.

O uso de rimas, assim como de repetições de palavras e de sons, intensifica a música do segundo poema de Tempo da Maria. O esquema de rimas de "Amar sem ser amado, ora pinhões!", além de realçar a sonoridade dos versos, sofre variações que, ao lado de mudanças tonais, marcam também a divisão da composição poética em diferentes andamentos.

No momento em que o eu lírico se identifica, de forma mítica, com a paisagem exterior (segundo bloco de estrofes), por exemplo, as rimas se desenvolvem de forma simétrica, refletindo, por meio do espelhamento sonoro, a busca da unidade de contrários, vale dizer, a mistura do mundo interior do poeta e da paisagem que o cerca.

\footnotetext{
44 ANDRADE, M. Dicionário musical brasileiro. Coordenação de Oneyda Alvarenga, 1982-84, e de Flávia Camargo Toni, 1984-89. Belo Horizonte: Itatiaia, 1999, p 6.

45 "Mokocê-cê-maká" é também o título de uma das "Canções típicas brasileiras" para canto e piano de VillaLobos, composta, com base em material colhido por Roquette- Pinto, em 1919 (KIEFER, B. Villa-Lobos e o modernismo na música brasileira. Porto Alegre: Movimento; Brasília: INL/ Fundação Nacional Pró-Memória, 1986, p 26 e 49).
} 
Me perdi pelas sensações.

Não sou eu, sou eus em farrancho,

E vem lavar minha retina,

Em maretas de poeira fina

Todas as coisas tamisando,

O Tâmisa das ilusões.

Cavam a terra do jardim.

É no meu peito. Como um ólio,

Me esparramo pela cidade,

$\mathrm{E}$ as coisas, nessa intimidade,

São um dilúvio de olhos, olhos

Meus, assuntados sobre mim.

Tudo se funde em minha vista.

Estou alegre. Coisa estranha,

Não sinto o bem, sorrio ao mal...

Será a inconsciência transcendental

Que enche a boca de Graça Aranha?

Todo infinito! ôh farra! ôh Lapa!

Não sei não. Porém, ver um Zeus,

Conhecem? Zeus de casimira,

Meio suado, vou no universo

Buscando o meu fogo disperso

Que pelas coisas girogira,

Roubado pelos Prometeus.

No terceiro bloco de estrofes, momento do encontro com a amada, a simetria de rimas ainda é mantida, revelando o desejo de união de contrários.

Às sacudidelas do bonde, 55

Na minha frente rósea chama

Crepita, ôh pescoço! Um ardor

Principiante, consolador,

Zeus (Zeus sou eu) gemendo chama:

- Fogo, onde estás, aonde? aonde?

Êxtase! Desejo! Loucura!

Quase dolorosa surpresa!

Espanto de não ser mais só!

E a gente imagina que é o pó

Que sufoca e, vai, com aspereza

Bota a culpa na Prefeitura.

No entanto, no quarto grupo de versos, ao quebrar, por meio de constatações racionais, o tom grandioso e sentimental que toma o discurso, instaurando o dilema do poeta que deseja o amor, no presente, mas sabe que o deverá esquecer, no futuro, as rimas, acompanhando a 
mudança, abandonam o esquema simétrico e aparecem de forma intercalada - "ão", "ar", “ão", "ar".

Minha paixão de sopetão!

Já nem posso mais respirar!

Que pescoço! que braços! quê!...

Bom... olhemos a natureza.

O céu se encurva sobre o chão

Num gesto forte de abraçar.

Que friúme em minha tristeza...

Rapazes! A minha alegria,

A minha alegria está presa

Num perfil duro de mulher!

Ela me olha tão fria, fria...

Ora! verifiquemos como

Rictus: "Merde! voilá l'hiver."

Poeta, sossegue, ela é casada...

Pois sim. Pensemos noutra coisa.

No que será?... Negro de suéter,

Que engraçado!... mas... que tristeza!

Esta vida não vale nada!...

Vou cantar a Louvação do Éter!
80

95

100

Após o momento inebriante de louvação ao éter, trecho marcado também pela simetria das rimas - "perigo", "prova", "nova", “contigo" e "amigo", "parte”, “entrou”, "sou”, "Malazarte", "perigo" -, o esquema simétrico é retomado, na última estrofe, sinalizando a união de opostos: o poeta possui Maria, mesmo não a possuindo.

É o fim. Lá fora dormirá

Paulicéia. Paz. Quase informe,

Ela dorme, dorme sorrindo,

Enquanto gemo o verso lindo

Com que as índias parecis dormem...

Uirô, mococê ce-macá...

O esquema de rimas que constrói a simetria dos versos, símbolo da síntese de contrários, além de revelar os dilemas do poeta múltiplo que, sendo muitos, é um, percorre “Amar sem ser amado, ora pinhões!" apontando o desejo de união com Maria, realizado, ao final, por meio da sublimação do amor, apesar de ter sofrido, em meio ao poema, o abalo racional da certeza da impossibilidade de realização amorosa, dilema traduzido por meio de rimas intercaladas. 
Além de enfatizar a melodia do poema por meio do uso de rimas, o poeta utiliza-se de recursos musicais próprios da música do Romantismo, confirmando, dessa forma, a tensão entre os ideais do escritor moderno e a atualização de recursos românticos, expressa já por meio da retomada do tema "amar sem ser amado". Como "para os românticos a música se torna sistematicamente a arte de exprimir os sentimentos por meio de sons" ${ }^{46}$, no poema do modernista, os sentimentos do eu lírico enamorado por uma dona inalcançável são expressos pela musicalidade própria dos compositores dessa época.

A maior liberdade formal dos românticos que, na música, realizam grandes modulações, indo, repentinamente, para regiões tonais diferentes, pode ser vista, no poema, por meio da agitação dos versos que oscilam entre a entrega ao sentimentalismo e os cortes do poeta moderno, titubeio acompanhado por mudanças abruptas de tonalidade - variação entre o êxtase sentimental, marcado por um tom exacerbado, e a calma procurada na paisagem da cidade, conseguida, depois, no tom velado do acalanto final. O "tom", além de ser um recurso musical, pode ser entendido, ainda, como uma das "modalidades afetivas da expressão" literária de que nos fala Alfredo Bosi. De acordo com o estudioso, além da "perspectiva", que dá o "inteligível cultural da mensagem artística", é preciso atentar para o tom do texto literário $^{47}$. Em “Amar sem ser amado, ora pinhões!", o tom dominante do poema, no sentido atribuído a essa palavra por Bosi, é contraditório e múltiplo, sendo construído, pelo poeta, como o resultado da sobreposição de tonalidades distintas. Assim, a modulação tonal que aproxima o poema das composições românticas compõe, ainda, o tom oscilante que determina o ethos do texto.

Como em uma peça romântica, o tema de "Amar" - a paixão do eu lírico pela dona ausente - "muda de aspecto e de interpretação [...] pra caracterizar estados psicológicos [...] diferentes da mesma coisa [...] pra significar mudanças sentimentais" ${ }^{48}$, vale dizer, para caracterizar a oscilação entre diferentes sentimentos do eu poético que, em princípio, reconhece o grande amor que o toma e, depois, levado pela certeza racional de não poder realizar o desejo, se entrega à tristeza resolvida, apenas, por meio da solução romântica: o amor, sublimado, é realizado ao acalentar a dona adormecida. Por meio da transformação de temas, ainda segundo Mário de Andrade, os compositores românticos tornam-se historiados,

\footnotetext{
${ }^{46}$ ANDRADE, M. Pequena história da música. Belo Horizonte: Itatiaia, 2003, p 135 (livro publicado em 1942).

${ }^{47}$ BOSI, A. A interpretação da obra literária. In: Céu, Inferno. São Paulo: Duas Cidades; Ed. 34, 2003 , p 468.

${ }^{48}$ ANDRADE, M. Pequena história da música. Belo Horizonte: Itatiaia, 2003, p 135.
} 
dando ao ouvinte a sensação de que se está narrando uma história ou um drama. ${ }^{49}$ No poema, o eu lírico, além de poder lançar mão da mudança temática, tem o recurso da palavra que, ao lado da música, conta a história e o drama do apaixonado. É interessante notar que a variação de aspectos temáticos se constrói, em “Amar sem ser amado, ora pinhões!", por meio do contraste entre a exacerbação do sentimentalismo romântico e a sua negação, dada pelo corte modernista. Dessa forma, para retomar a estrutura do romantismo musical, o poeta lança mão do embate entre o sentimentalismo e o seu contrário, ou seja, a fuga ao cume da comoção romântica, exagero definido por Mário de Andrade como patológico ${ }^{50}$.

Além da variação temática e das modulações de tom, a falta de regularidade na acentuação dos versos de "Amar sem ser amado, ora pinhões!", que não segue um padrão fixo, nos remete, também, às frases irregulares e aos ritmos complexos da música do Romantismo.

Os diferentes andamentos que formam o poema, além de recriarem o movimento da viagem de bonde, constroem um esquema musical apreciado pelos românticos, em que partes de caracteres diferentes se opõem em uma estrutura ternária (ABA), como nos ensina Bennett $^{51}$. Ao iniciar o poema com um andamento calmo e um tom mais comedido, descrevendo a paisagem da cidade, depois de modulações e de mudanças rítmicas que marcam os versos centrais de "Amar sem ser amado, ora pinhões!", em que o poeta oscila entre o medo de amor e o desejo sensual, o andamento inicial é retomado. No entanto, como movimentos cíclicos são formados pela retomada do início de forma modificada, o poeta que, nos primeiros versos do poema era o gigolô que, protegido pela distância do bonde, se divertia com as moças perdidas no ouro, ao seu final, abandona o tom galhofeiro e observa Paulicéia adormecida, sentindo, ao mesmo tempo, a amada dormir em si mesmo - "sobre seu sonho".

Não podemos nos esquecer de que o Romantismo, ainda de acordo com Mário, "partiu do espírito popular e consistiu numa deformação nova desse espírito" ${ }^{52}$. De acordo com o estudioso, como para o povo tem valor a expressão musical como função social específica, os românticos, além de unirem a palavra à música, tornando-a compreensível e, portanto, útil, dão a ela uma função: exprimir os sentimentos. Para o poeta, se o povo é "brutalhão" em suas manisfestações - "chora gritado, aplaude berrando, briga a pau" -, os românticos buscam a

\footnotetext{
${ }^{49}$ Ibidem, p 135.

${ }^{50}$ Ibidem, p 136.

${ }^{51}$ BENNETT, R.Uma breve história da música. Rio de Janeiro: Zahar, 1986, p 59.

${ }^{52}$ ANDRADE, M. Pequena história da música. Belo Horizonte: Itatiaia, 2003, p 134.
} 
comoção grandiosa por meio da deformação da franqueza popular, transformando-a num "repugnante cultivo da dor" e construindo, assim, uma música que vibra "duma comoção não imaginada ainda, violenta, expressiva" ${ }^{53}$, da qual o eu lírico de "Amar sem ser amado, ora pinhões!" tenta escapar. Apesar de aproximar-se dos compositores românticos ao buscar, nos versos populares, a sonoridade de seus poemas, o poeta modernista, em “Amar", ao mesmo tempo em que resgata o modo de ser romântico, reconhece seus exageros sentimentais, incorporando-os de forma crítica à sua lírica, na medida em que os impulsos da paixão, ao lado da consciência racional, criam o movimento hesitante do poema, construído por meio de rupturas que percorrem os versos. Assim, dando espaço para a discussão crítica do ideal romântico, mas temendo sucumbir ao exagero sentimental criticado pelos modernistas, Mário de Andrade reafirma o medo de amar em nova chave.

Além de resgatar um tema do Romantismo - o medo do amor - e recursos musicais empregados, na música, nesse período - mudanças repentinas de tonalidade, oscilação temática, caráter historiado, inspiração na cultura popular, assim como o esquema ternário ABA -, o poeta utiliza-se, na composição de seu poema, de fragmentos, expediente caro à música romântica. Discorrendo sobre as várias formas de fragmento usadas na música no período romântico, Charles Rosen, ao estudar obras de Schumann, mostra como "uma nota, [...] uma frase, ou mesmo [...] uma seção [...] parecem, à primeira vista, vir 'de fora' da forma" ${ }^{54}$. A citação de trechos de outros músicos, assim como de momentos da própria obra do compositor, de acordo com o estudioso, "abalam a simetria e as convenções da forma, sem que jamais realmente as destrua" 55 .

Ao invocar, em meio a seus versos, outros poetas, assim como trechos da poesia popular e da mitologia clássica, Mário de Andrade não apenas faz uso de fragmentos, de forma similar aos românticos, mas constrói seu poema com base em um aproveitamento rapsódico, procedimento próprio da tradição brasileira. Compondo a rapsódia, os versos de Antonio Nobre são retomados ao lado da invocação da tardinha vermelha de Gonçalves Dias, um dos poetas românticos brasileiros que trabalhou o tema do medo do amor. Da mesma forma, o verso de Jehan Rictus, escritor francês que se utiliza da linguagem prosaica para denunciar diferenças sociais, é transcrito, assim como "arranjos" de Alfred Musset são invocados, formando uma bricolagem que, se baseando na citação de vários poetas, lembra o

\footnotetext{
${ }^{53}$ Ibidem, p 134-137.

${ }^{54}$ ROSEN, C. A geração romântica. Trad. de Eduardo Seincman. São Paulo: EDUSP, 2000, p 153.

${ }^{55}$ Ibidem, p 151.
} 
recurso empregado pelo improvisador popular. Além disso, a história grega do roubo do fogo por Prometeu é reescrita pelo eu lírico, que se compara ao deus clássico - Zeus. Formando o colorido do mosaico, aparecem, ainda, o dito popular "vá por ceca e Meca", reescrito pelo poeta, assim como a referência a Graça Aranha, e a invocação da moral cristã, por meio dos dez mandamentos - "as Tábuas da Lei”. Resgatando versos e crenças da cultura do povo, a voz lírica completa sua rapsódia: a expressão popular "Amar sem ser amado" dá título ao poema, assim como a crença na Iara e a cantilena indígena fecham a composição poética "Uirô, mococê ce-macá”. Da mesma forma, na rapsódia romântico-moderna, a musicalidade da fala do povo é reescrita por meio do uso de expressões prosaicas - "que nem", "si”, "assuntados", "ver um Zeus", "relumeia”, “e, vai”, "friúme” - , assim como por meio do emprego de formas musicais populares - a louvação e o acalanto. Utilizando-se de fragmentos para a criação de seu texto, o poeta moderno confirma sua aproximação do romantismo musical, assim como resgata a forma da rapsódia, freqüente na música popular, estrutura adotada, ainda, na construção de Macunaíma.

É interessante notar que, em meio à recuperação de temas, tons e estruturas musicais românticas, o eu lírico se identifica com um dos deuses clássicos - Zeus -, criando a tensão que constitui a modernidade do poema.

Para melhor compreendermos as implicações da junção de temas clássicos e românticos, em “Amar sem ser amado, ora pinhões!”, podemos recorrer a Hegel, não nos esquecendo, no entanto, que, para o filósofo, a "arte romântica" se prende ao Cristianismo e à valorização do indivíduo, tendo um alcance muito maior do que o conferido por nós a essa expressão.

De acordo com Hegel,

\begin{abstract}
enquanto conteúdo, [a arte clássica] apreende o espiritual [...] na medida em que ela traz para o seu próprio âmbito a natureza e suas potências [...] [Na arte clássica], a Forma exterior é o fenômeno natural no corporal e sensível [...], a completude da arte alcançou justamente seu topo pelo fato de o espiritual [ser] atravessado completamente por seu fenômeno exterior, ter idealizado o natural nesta bela união e de tê-lo feito realidade adequada do espírito em sua individualidade substancial mesma. ${ }^{56}$
\end{abstract}

No poema, a união da paisagem exterior ao interior do poeta, que tem lugar no segundo e no início do terceiro grupo de estrofes, além de sinalizar a identificação pré-lógica do eu lírico com a paisagem que o cerca, em uma recuperação dos traços primitivos do povo

\footnotetext{
${ }^{56}$ HEGEL, G. W. F. Cursos de estética. Vol. II. Tradução de Marco Aurélio Werle, Olivier Tolle. São Paulo: EDUSP, 2000, p 207 e 251.
} 
brasileiro, invoca também um dos aspectos da arte clássica, vale dizer, a união entre as potências naturais (o exterior) e o espiritual (o interior) do eu poético que, logo depois, se compara a Zeus. A presença de traços clássicos, em "Amar sem ser amado, ora pinhões", antecede, paradoxalmente, os dilemas íntimos do eu lírico que revelam o caráter romântico do espírito que se volta para si mesmo, já que, após se constituir como um deus grego, uma potência natural individualizada, o eu poético, ao encontrar a amada, se rende ao amor romântico.

Se o ponto central da arte clássica é, de acordo com Hegel, constituído por meio da união perfeita entre conteúdo e forma ${ }^{57}$, de maneira diferente, a arte romântica, de acordo com o estudioso, não mais se preocupa com essa união ideal, mas, antes, afirma a "elevação do espírito para si mesmo [...] [como seu] princípio fundamental”. O romântico, portanto, procura "reconduzir a si mesmo do exterior para sua interioridade consigo mesmo e de estabelecer a realidade exterior como uma existência que não lhe é adequada" ${ }^{58}$.

Ainda de acordo com o filósofo alemão,

na arte romântica a subjetividade infinita não está sozinha nela mesma assim como o deus grego, que vive em si mesmo inteiramente completado na beatude de seu acabamento, mas [...] ela sai de si mesma e entra em relação com o outro, mas que é o seu outro, no qual ela mesma novamente se reencontra e permanece junto a si mesma em unidade. [...] Esta vida em si mesma em um outro é, enquanto sentimento, a interioridade do amor. ${ }^{59}$

Assim, o deus clássico com características humanas - suado, vestido com casimira e andando de bonde - rende-se ao amor romântico, ao encontrar a própria chama, roubada por Prometeu, em seu outro - na amada. No entanto, o impedimento - "ela é casada" - proíbe "a relação com o outro espiritual, que está de tal modo ligado com a interioridade, que apenas neste outro a alma vive" ${ }^{60}$, dando lugar ao dilema do eu poético - desejar e não poder possuir a si mesmo que vive em Maria. Assim, a busca da própria identidade, tema que percorre a obra de Mário de Andrade, é, em “Amar sem ser amado, ora pinhões!", intensificada pelo amor não correspondido, e a "chama" - a identidade do poeta - fica presa no perfil duro e frio da amada.

\footnotetext{
${ }^{57}$ Ibidem, p 157.

${ }^{58}$ Ibidem, p 252-3.

${ }^{59}$ Ibidem, p 268.

${ }^{60}$ Ibidem, p 268.
} 


\section{Danças dramáticas}

O movimento da viagem, permeando a obra do poeta que caminha, por meio de seus versos, em busca de uma identidade, marca, como vimos, dois textos de Tempo da Maria “Amar sem ser amado, ora pinhões!" e "Louvação da tarde" -, poemas itinerantes dispostos, no grupo, de forma significativa. O primeiro aparece logo após os versos de abertura - "Moda do corajoso" - e o segundo antecede o momento de fechamento da série - "Maria" -, ocupando, portanto, lugares simetricamente opostos. A simetria revelada pela disposição dos poemas itinerantes aponta as diferenças e semelhanças entre as duas composições poéticas, já que, em posição simétrica, são similares, e, ao mesmo tempo, contrárias. A diferença principal entre os dois poemas fica por conta da mudança de foco operada a partir de "Louvação" que, de acordo com Antonio Candido, "representa a passagem da poesia mais exterior dos primeiros tempos de luta modernista para a poesia mais interior da última fase" ${ }^{1}$.

Antes de nos aprofundarmos no estudo de "Louvação da tarde" em comparação com “Amar sem ser amado, ora pinhões!”, é interessante pensarmos na estrutura do grupo Tempo da Maria, procurando compreender, por meio da disposição e da temática dos poemas, aspectos importantes a serem levados em conta na análise de "Louvação". O grupo é constituído por sete poemas que, um ao lado do outro, compõem uma forma cara ao Romantismo, a saber, o "ciclo" - "uma obra [musical] em que a significação e a efetividade dos membros individuais dependem de suas localizações numa ordenação mais ampla" ${ }^{2}$-, nos moldes dos Prelúdios op. 28 de Chopin, descritos por Charles Rosen como um conjunto de fragmentos que formam uma unidade ${ }^{3}$.

A ordenação dos poemas que formam o ciclo Tempo da Maria é significativa, já que não apenas “Amar sem ser amado, ora pinhões!” e "Louvação da tarde” são apresentados em posições simétricas, mas a disposição das outras composições poéticas segue também uma simetria: introdução ("Moda do corajoso"), deslocamento ("Amar sem ser amado, ora pinhões!”), uma cantiga (“Cantiga do ai”), um poema narrativo central que constitui o ponto de intersecção da simetria ("Lenda das mulheres de peito chato"), outra cantiga ("Eco e o descorajado"), deslocamento novamente ("Louvação da tarde") e um poema de fechamento

\footnotetext{
${ }^{1}$ CANDIDO, A. O poeta itinerante. In: O discurso e a cidade. São Paulo: Duas Cidades, 1993, p 257.

${ }^{2}$ ROSEN, C. A geração romântica. Trad. de Eduardo Seincman. São Paulo: EDUSP, 2000, p 139.

${ }^{3}$ Ibidem, p 134.
} 
("Maria"). O movimento musical cíclico que marca os dois poemas itinerantes de Tempo da Maria - "Amar sem ser amado, ora pinhões!” e, como veremos mais adiante, "Louvação da tarde" -, construídos de forma semelhante ao rondó, em que o final é a retomada do começo modificado, aparece, portanto, também na disposição dos poemas do grupo que, por meio da organização simétrica, invocam a forma da uróboro, confirmando a procura de uma definição para a identidade fragmentada do poeta, assim como de seu país, ao simbolizar a união de contrários. A forma circular construída por meio da disposição dos poemas faz lembrar, ainda, o caráter cíclico das danças dramáticas populares estudadas por Mário de Andrade.

O estudo dos bailados populares - reisados, cheganças, congos, pastoris, bumba-meubois -, agrupados por Mário sob o nome genérico de "Danças Dramáticas”, foi uma das grandes preocupações do modernista, pesquisador interessado em compreender a tradição folclórica e musical do povo brasileiro. Sob esse nome geral, Mário de Andrade agrupou não apenas bailados que giram em torno de uma ação dramática, mas também outras danças coletivas formadas, rapsodicamente, pela concatenação de diversas peças coreográficas ${ }^{4}$. Consideradas pelo estudioso como "uma das manifestações mais características da música popular brasileira" 5, as danças dramáticas têm sua estrutura, assim como seus aspectos simbólicos, retomados e atualizados pelo poeta moderno de Tempo da Maria. Dessa forma, Mário segue, por meio de sua produção literária, ao aproveitar em versos eruditos a tradição popular das danças, o conselho dado por ele mesmo aos compositores de seu tempo: introduzir nas obras eruditas musicais os componentes populares próprios do povo brasileiro, modificando-os e assimilando-os, construindo, assim, a expressão singular do Brasil.

Um dos aspectos centrais das danças dramáticas, a saber, a encenação da morte e renascimento de um bem coletivo - o boi -, é a permanência secular, na cultura brasileira, da noção mística de morte e ressurreição encontrada nos ritos de vegetação ${ }^{6}$, estudados por Mário, de acordo com Telê Ancona Lopez, no livro de Frazer, The golden bough, obra que aponta, ainda, como nos lembra a estudiosa, o deslocamento do espírito vegetal cultuado para a forma humana ou animal ${ }^{7}$. Como afirma Mário,

[...] essa luta de um bem contra um mal [outro elemento constante nas danças dramáticas] insiste entre nós no princípio mágico, mais primitivo que as

\footnotetext{
${ }^{4}$ ANDRADE, M. Danças dramáticas do Brasil. Edição organizada por Oneyda Alvarenga. Belo Horizonte: Itatiaia, 2002, p 71.

${ }^{5}$ Ibidem, p 31.

${ }^{6}$ Ibidem, p 33.

${ }^{7}$ LOPEZ, T. P. Mário de Andrade: ramais e caminhos. São Paulo: Duas Cidades, 1972, p 127.
} 
religiões propriamente ditas e adotado por muitas delas, de "morte e ressurreição" de um bem da coletividade, em principal o reverdecimento da vida, do alimento, tanto da carne do bicho como do vegetal, depois do inverno ou da seca. Nas danças dramáticas mais variadas se multiplica invariavelmente, como princípio ideativo, esse complexo da morte e ressurreição do bicho, tanto na maioria dos reisados tradicionais, como nos Cordões de Bichos atuais da Amazônia, e culminando no Bumba-meu-Boi. ${ }^{8}$

Como nos lembra Telê, Mário compreendeu que, no Brasil, o boi teve maior importância econômica do que a terra e, portanto, uma grande valorização mítica, já que, no país tropical, sem diferenças marcantes entre as estações, como acontece na Europa, o culto do renascimento da vegetação seria importante apenas em função do boi ${ }^{9}$.

Discorrendo sobre a data da realização dos festejos do Bumba no Norte e no Nordeste do país, Mário de Andrade chega a conclusões interessantes:

O Boi mal comparando, parece assumir uma posição de Dionísio, símbolo do reflorescimento e do tempo fecundo. Ora é curioso pois que a celebração dele no Norte venha justamente em junho, tempo de inverno, tempo de cheia nos rios, tempo de menos febre, mais facilidade na vegetação ao passo que no Nordeste está também quando chega o que por lá chamam de "inverno", tempo de natal, tempo das águas, tempo de reflorescimento, e de muito mais facilidade. Parece de fato haver uma razão profundamente humana e a seu modo religiosa, nessa escolha de datas. ${ }^{10}$

Telê afirma que a razão humana que justifica a escolha de datas, apontada pelo poeta no trecho transcrito, é o culto do apogeu da vegetação por meio do sacrifício de seu símbolo animal, realizada em tempo de fecundidade, ficando guardada, assim, a força da terra para a ressurreição depois da estiagem ${ }^{11}$. Tempo da Maria, tempo cíclico de fecundidade amorosa, é o momento escolhido pelo poeta para pôr em cena o tema da morte e ressurreição, por meio de versos. No grupo de poemas, é dramatizada, ainda, a luta entre duas forças opostas - o desejo sensual e a racionalidade -, nos moldes de uma dança dramática.

A voz lírica de Tempo da Maria, após o poema de abertura, se entrega, em "Amar sem ser amado, ora pinhões!", ao ventinho piricica, dissolvendo-se em vários "eus" e formando, por meio de sua multiplicação, o conjunto de dançadores - o farrancho - que

\footnotetext{
${ }^{8}$ ANDRADE, M. Danças dramáticas do Brasil. Edição organizada por Oneyda Alvarenga. Belo Horizonte: Itatiaia, 2002, p 60 (nota de roda-pé).

${ }^{9}$ LOPEZ, T. P. Mário de Andrade: ramais e caminhos. São Paulo: Duas Cidades, 1972, p 128-9.

${ }^{10}$ ANDRADE, M. Manuscrito. In: LOPEZ, T. P. Mário de Andrade: ramais e caminhos. São Paulo: Duas Cidades, 1972, p 129.

${ }^{11}$ LOPEZ, T. P. Op. cit., p 129.
} 
representará as danças dramáticas. Por meio da própria divisão, o poeta é o boi sacrificial que morre simbolicamente para depois renascer. Como nos lembra Telê, nos romances populares, o animal bovino, depois de capturado ou morto, "é dividido, resulta no próprio banquete do totem que faz crescer socialmente sua dimensão e que dá, para Mário de Andrade, mais uma prova do sentido coletivizador do animal" ${ }^{12}$. O eu lírico, que aparece no poema de abertura de Remate de males (1930) como um boi dividido - "Sou trezentos, sou trezentos e cinqüenta" -, e multiplicado para o banquete totêmico de "Amar sem ser amado, ora pinhões!", irá, depois, confirmar sua identificação com a figura do símbolo nacional em um dos poemas de Lira paulistana (1945), em que, como no final do romance do "Boi-Espácio", transcrito por Telê ${ }^{13}$, o poeta pede que, após sua morte, seja divido e espalhado pela cidade "Quando eu morrer quero ficar,/ Não contem aos meus inimigos,/ Sepultado em minha cidade,/ Saudade."

A morte ritual de "Amar sem ser amado, ora pinhões!" mostra a entrega do eu lírico aos ritmos populares que ditam os versos de Tempo da Maria, figurando como um rito iniciático necessário para a total identificação da voz lírica com a música e a dança próprios do povo, assim como uma preparação para a entrada na fase madura dos anos trinta. Além disso, por meio do sacrifício ritual, o poeta, ao mesmo tempo em que resgata a tradição popular, oferece a si mesmo partilhado, invertendo a fórmula assumida até então: se, no Clã do jabuti (1927), Mário resgata em versos a cultura popular brasileira, procurando sentir o gosto do Brasil e revelando uma fome estomacal por nossas tradições - "Brasil.../ Mastigado na gostosura quente de amendoim..." 14 -, em Remate de Males (1930), ao retomar a preocupação com o nacional que ditou os versos do Clã , o poeta não apenas deglute o outro, mas entrega o próprio ser, já modificado pelo contato com a cultura popular, como o banquete totêmico. A partir de Remate de males, a procura dos tons, cores e ritmos da identidade brasileira é realizada dentro do próprio ser do poeta que, multifacetado, é - numa identificação mítica total - o povo brasileiro: o farrancho que percorre as ruas e o boi que simboliza o Brasil.

Entregando-se ao ritmo extasiante das danças brasileiras, a voz lírica de Tempo da Maria não deixa de ressaltar o caráter dúbio e complexo de nosso povo, ao justapor, na retomada dos bailados dramáticos, tradições díspares: o poeta moderno se identifica, em

\footnotetext{
${ }^{12}$ Ibidem, p 133-4.

${ }^{13}$ Ibidem, p 134-5.

${ }^{14}$ Verso do poema de abertura de Clã do jabuti, "O poeta come amendoim".
} 
“Amar sem ser amado, ora pinhões!”, com a figura clássica de Zeus, ao mesmo tempo em que retoma aspectos musicais românticos; da mesma forma, assim como inaugura a dança dramática empunhando um instrumento erudito - a viola de amor -, resgata versos populares sob a ótica do estudioso que lê Freud, estuda Frazer e conhece as vanguardas européias.

Outro elemento de grande importância nas danças dramáticas do Brasil, também retomado pelo poeta de Tempo da Maria, é o cortejo. O costume da marcha religiosa - das procissões - que, de acordo com Mário de Andrade, foi criado na Europa cristã para substituir as tradições pagãs das Maias e Janeiras, cultivado séculos depois pelos jesuítas no Brasil, serviu para "tradicionalizar no povo a técnica do brinquedo ambulatório" 15.

[O] cortejo [das danças dramáticas] [...] perambula pelas ruas, cantando e dançandinho, em busca do local onde vai dançar a parte propriamente dramática do brinquedo. Esse cortejo, quer pela sua organização quer pelas danças e cantorias que são exclusivas dele, já constitui um elemento especificamente espetacular. Já é teatro. Fazem parte dele as cantigas religiosas, os dobrados de marcha, as despedidas, cantos de trabalho alusivos e danças puras: por vezes atingindo um desenvolvimento tão desmedido que podem dar ao cortejo uma importância prática bem maior que a da representação propriamente dramática. ${ }^{16}$

"Amar sem ser amado, ora pinhões!" e "Louvação da tarde", os dois poemas itinerantes de Tempo da Maria, compõem o cortejo das danças dramáticas de Mário de Andrade, além de resgatarem, cada um a sua maneira, a tradição romântica apontada por Antonio Candido, a saber, a criação poética inspirada pelo movimento do corpo. Dessa forma, a música romântica de “Amar sem ser amado, ora pinhões!”, formada por diferentes andamentos que seguem o movimento do bonde, assim como o andamento de "Louvação da tarde", inspirado na viagem do forde, compõem também, em uma sobreposição de tradições, a música entoada pelo farrancho popular - pelo poeta multiplicado - em busca do local em que se desenvolverá a parte dramática dos festejos, assumindo, assim como nas danças dramáticas, uma notável "importância prática", já que coloca em cena, antecipadamente, os dilemas do eu lírico.

Discorrendo sobre a forma geral da maioria de nossas danças, Mário de Andrade aponta alguns elementos mais ou menos fixos:

\footnotetext{
${ }^{15}$ ANDRADE, M. Danças dramáticas do Brasil. Edição organizada por Oneyda Alvarenga. Belo Horizonte: Itatiaia, 2002, p 38-9.

${ }^{16}$ Ibidem, p 37.
} 
uma parte central, a que chamam de "embaixada", que é propriamente dramática e exige coreografia de caráter imitativo, quando não dramatização legítima: parte central esta que é circundada por "cantigas" [...], peças ou de marcha ou de coreografia pura, sobre vário assunto, havendo sempre entre as iniciais peças religioso-católicas, e entre as finais peças de despedida e de agradecimento às pessoas gradas presentes e ao público em geral. ${ }^{17}$

O estudioso ressalta, ainda, a presença, nas danças dramáticas, de uma parte introdutória, além de louvações ${ }^{18}$.

A estrutura do grupo de poemas Tempo da Maria é similar à forma das danças dramáticas. Além do canto introdutório - "Moda do corajoso" -, dos cortejos cantados e dançados - "Amar sem ser amado, ora pinhões!" e "Louvação da tarde" -, das cantigas que acompanham o cortejo - "Cantiga do ai" e "Eco e o descorajado" -, e de um poema de fechamento - "Maria" -, Tempo da Maria possui, ainda, uma embaixada: a "Lenda das mulheres de peito chato", entrecho dramático inspirado em lenda dos índios taulipangue. Ao fazer uso de uma história indígena para a criação da parte dramática propriamente dita de suas danças, o poeta se reafirma como o rapsodo, já que colhe na cultura do povo os fragmentos de sua composição poética.

O aproveitamento rapsódico, além de ser um dos traços românticos da música de “Amar sem ser amado, ora pinhões!", em que o poeta faz uso de fragmentos, é também uma das formas populares de compor própria de nossas danças dramáticas. De acordo com Mário de Andrade, já no século XVIII e XIX, alguns bailados, com enredo muito vago, eram agrupados como números diferentes de um mesmo cortejo ${ }^{19}$, formando, assim, uma rapsódia.

Discorrendo sobre o Reisado - uma de nossas danças dramáticas -, o poeta destaca o caráter rapsódico que deu base à sua criação.

É mesmo interessante como a criação do Reisado se assemelha à das Paixões da Idade Média. [...] Mas a criação de entrechos teatrais era coisa por demais complicada pra nascer assim anonimamente no seio da coletividade folclórica: requeria autor semierudito ao menos. É óbvio que uma criação deveras anônima e coletiva jamais não poderá se fazer de encomenda. Assim, o povo recorreu aos seus romances, os quais, da mesma forma que a Paixão de Cristo, nos Evangelhos, são eminentemente teatrais. ${ }^{20}$

\footnotetext{
${ }^{17}$ Ibidem, p 100.

${ }^{18}$ Ibidem, p 60.

${ }^{19}$ Ibidem, p 40.

${ }^{20}$ Ibidem, p 51.
} 
Os Reisados são definidos por Mário de Andrade como adaptações dramáticocoreográficas de romances e cantigas populares. O estudioso acredita, ainda, que, considerados curtos pelo povo, os primeiros Reisados foram reunidos em grupos maiores. $\mathrm{O}$ costume de finalizar a série de Reisados com a dança do boi, fez com que surgisse um bailado único: o Bumba-meu-Boi ${ }^{21}$, "a mais complexa, estranha, original de todas as nossas danças dramáticas [,] por vezes mesmo uma verdadeira revista de números vários" ${ }^{22}$. Mário aponta também o caráter rapsódico das Cheganças, festejos dramáticos que celebram os feitos marítimos dos portugueses - "Chegança de marujos" - ou as lutas entre cristãos e mouros "Chegança de mouros" - que, apesar da origem ibérica, possuem, como mostra o poeta, uma “indiscutível formação brasileira em seu conjunto [...], [pois] foi a gente brasileira que, reunindo e amalgamando um mundo de tradições diversas aqui chegadas, fez nestes dois bailados a rapsódia mais admirável." 23.

O caráter agregador e rapsódico das danças dramáticas é resgatado pelo poeta de Tempo da Maria, grupo de poemas em que um "núcleo básico é [...] recheado de temas apostos a ele; romances e outras quaisquer peças tradicionais [...] se grudam nele; textos e mesmo outros núcleos de outras danças se ajuntam a ele." ${ }^{24}$, fruto do trabalho do poetapesquisador que, colhendo na tradição popular o "espólio tradicional", o organiza “deturpando [...] ajuntando o necessário em estrofes, música, episódios pra que os elementos mais ou menos desconjuntados se [reúnam] num todo". 25

\section{Louvação da tarde}

Apesar de compor, ao lado dos outros poemas do grupo, a dança dramática de Tempo da Maria, "Louvação da tarde" é diferente dos cantos laudatórios populares que acompanham os bailados representados pelo povo. Antonio Candido afirma que o texto é um interessante caso de poema moderno feito de forma antiga, apontando a escolha do decassílabo branco, usado, em "Louvação", pela primeira e única vez na obra de Mário de Andrade, como forma de realizar o desejo, expresso pelo poeta em carta a Manuel Bandeira, de construir um poema nos moldes das composições poéticas reflexivas dos ingleses românticos, já que o decassílabo se aproxima do pentâmetro iâmbico usado por eles. Além

\footnotetext{
${ }^{21}$ Ibidem, p 55-6.

${ }^{22}$ Ibidem, p 56.

${ }^{23}$ Ibidem, p 93.

${ }^{24}$ Ibidem, p 56.

${ }^{25}$ Ibidem, p 116.
} 
disso, Candido entende a escolha métrica como prova do triunfo do Modernismo, já que mostra a "confiança adquirida por quem é capaz de incorporar as conquistas expressionais e temáticas a um esquema do passado" ${ }^{26}$. "Louvação da tarde", portanto, é um momentochave, como afirma o estudioso, tanto na obra de Mário, como na história do Movimento Modernista. O entroncamento do Modernismo na tradição se dá também por meio do resgate, ou da "amena paródia", como diz Candido, de uma espécie poética, a meditação, largamente utilizada pelos românticos, em que o corpo, em movimento, serve para espertar a mente. ${ }^{27}$ Dessa forma, "Louvação da tarde", ao fazer parte do grupo de poemas que atualiza as danças dramáticas populares, revela a singularidade do poeta que, de acordo com Candido, passa "do modernismo propriamente dito à modernidade [ao] recupera [r] a tradição [e] superá-la" ${ }^{28}$, já que a forma erudita, atualizada pelo olhar modernista, compõe, ao lado da recuperação de formas populares, a rapsódia marioandradina.

Lendo os poemas de Tempo da Maria de forma seguida, o que mais chama atenção em "Louvação da tarde" é a diferença de tom dessa composição poética, considerando, aqui, o termo "tom" no sentido dado a ele por Bosi em seu texto "A interpretação da obra literária" ${ }^{29}$. O poema possui um tom comedido, moderado, sempre em busca do apaziguamento, próprio do “poema poesia” que Mário de Andrade se dispôs a fazer.

Agora meu desejo é esse: construir o poema pau, o poema que não tem nenhuma excitação exterior, nem de pândega, nem de efeitos nenhuns nem de sentimentos vivazes. Nada que flameje, que rutile, que espicace. Nada de condimentos nem de enfeites. O poema poesia construído com pensamento condicionando o lirismo que tem de ser enorme (sinão não transparece) $o$ mais formidável que puder porém duma ardência como que escondida porque inteiramente interior. Enfim: o poema inglês. Shelley, Keats, Wordsworth, Swinburne, Yeats, essa gente. Pleiteio por Álvares de Azevedo contra Castro Alves, caso típico de poesia excitante, poesia condimento, poesia cocktail, poesia-coisas-assim [...] o poema que carece ser lido e entendido e o amor verdadeiro há-de descobrir dentro dele o fogo e o foco ardentíssimos porém que não queimam, em vez elevam consolam e são fecundos. ${ }^{30}$

Contidos sob o discurso comedido de "Louvação da tarde", os sentimentos exacerbados do poeta, explícitos nos poemas anteriores de Tempo da Maria, transparecem

\footnotetext{
${ }^{26}$ CANDIDO, A. O poeta itinerante. In: O discurso e a cidade. São Paulo: Duas Cidades, 1993, p 258.

${ }^{27}$ Ibidem, p 260-264.

${ }^{28}$ Ibidem, p 278.

${ }^{29}$ BOSI, A. A interpretação da obra literária. In: Céu, Inferno. São Paulo: Duas Cidades; Ed. 34, 2003, p 468.

${ }^{30}$ Correspondência Mário de Andrade \& Manuel Bandeira . Organização, introdução e notas de Marcos Antonio de Moraes. São Paulo: EDUSP; IEB-USP, 2001, p 262. [carta de Mário de Andrade escrita em 1925]
} 
apesar de condicionados pelo pensamento do eu lírico, já que são de uma ardência interior notável. Antonio Candido entende "Louvação" como "o momento de contemplação serena, pressupondo o esforço de paz interior" ${ }^{31}$. É justamente o esforço do poeta em mostrar-se apaziguado, ao lado de momentos em que seu tumulto interior se entremostra, que constrói a singularidade de "Louvação da tarde" e revela, de forma não explícita, a dor do poeta que se debate entre os desejos e as possibilidades.

"Louvação da tarde" é um poema longo organizado de forma cíclica, semelhante à estrutura ABA recorrente em composições musicais. Ele é formado por uma introdução, em que o poeta invoca e louva a tarde, por um desenvolvimento, composto por três devaneios despertados pela mente em movimento, e pela retomada da louvação em forma de despedida, em que o eu lírico anuncia o final da viagem e a aproximação da noite.

\section{LOUVAÇÃO DA TARDE}

Tarde incomensurável, tarde vasta, Filha de Sol já velho, filha doente

De quem despreza as normas da Eugenia,

Tarde vazia, dum rosado pálido,

Tarde tardonha e sobretudo tarde

Imóvel... quase imóvel: é gostoso

Com o papagaio louro do ventinho

Pousado em minha mão, pelas ilhotas

Dos teus perfumes me perder, rolando

Sobre a desabitada rodovia.

Só tu me desagregas tarde vasta

Da minha trabalhadeira. Sigo livre,

Deslembrado da vida, lentamente,

Com o pé esquecido do acelerador.

E a maquininha me conduz, perdido

De mim, por entre cafezais coroados,

Enquanto meu olhar maquinalmente

Traduz a língua norteamericana

Dos rastos dos pneumáticos na poeira.

$\mathrm{O}$ doce respirar do forde se une

Aos gritos ponteagudos das graúnas,

Aplacando meu sangue e meu ofego.

São murmúrios severos, repetidos,

Que me organizam todo o ser vibrante

Num método sadio. Só no exílio

De teu silêncio, os ritmos maquinares

Sinto, metodizando, regulando

O meu corpo. E talvez meu pensamento...

${ }^{31}$ CANDIDO, A. Op. cit., p 268. 
A tarde louvada assume, no poema, traços femininos, pois é filha enferma do símbolo do nosso tropicalismo moreno e mestiço: o Sol já velho que despreza as normas da Eugenia, ciência que pregava o valor da raça pura, em voga no Brasil daquela época. A filha do calor tem a cor rosada, fruto da mistura de contrários - o branco e o vermelho -, mesma cor da pele de Maria, comparada, em "Cantiga do Ai”, ao entardecer - "Ela é quieta e clara, ela é rosicler,/ É a boca-da-noite virada mulher". Ao louvar a tarde, de certa forma, o poeta enaltece também, de maneira sublimada, a amada inatingível que, como o momento vespertino, é quieta - "Imóvel... quase imóvel". A tarde tardonha possui, ainda, perfumes nos quais o eu poético se perde, como se estivesse se entregando aos eflúvios da mulher desejada. Incomensurável, sem medida comum com outra grandeza e, portanto, sublime, no sentido kantiano, a tarde é, assim como a amada do poeta, "aquilo em comparação com o qual tudo o mais é pequeno". 32

Da mesma forma como em “Amar sem ser amado, ora pinhões!” a voz lírica, no início de sua viagem, é tocada pelo "ventinho piricica", o poeta itinerante de "Louvação da tarde", ao começar a percorrer lentamente, em um forde, a rodovia solitária, sente empoleirado em seu braço o "papagaio louro do ventinho", vento dourado da tarde - louro - que roça de leve sua mão, como uma ave. Como o eu lírico de “Amar sem ser amado, ora pinhões!”, o eu poético de "Louvação", ao ser tocado pelo vento, se entrega ao ritmo da paisagem que o cerca. No entanto, no penúltimo poema de Tempo da Maria, o poeta não é multiplicado em diferentes "eus" que se dissolvem nas águas da Paulicéia. Ao contrário, o verbo "desagregar" que, em um primeiro momento, sugere uma fragmentação - "só tu me desagregas tarde vasta" -, ao ser completado pelo verso seguinte - "da minha trabalhadeira" -, mostra a individualidade do eu lírico.

O poeta encontra, no silêncio quase total da tarde imóvel, rodeado por cafezais prontos para a colheita, o exílio que faz possível sua entrega à sonoridade dos roncos "severos" graves - da maquininha e do grito agudo e triste das graúnas ${ }^{33}$, música que invade seu corpo e seu pensamento, modificando-lhes o ritmo e regulando-lhes a vibração. Se “Amar sem ser amado, ora pinhões!" é o momento da entrega sacrificial do eu lírico, "Louvação da tarde" é a

\footnotetext{
32 “Se, porém, denominamos algo não somente grande, mas simplesmente e em todos os sentidos (acima de toda a comparação) grande, isto é, sublime, então [...] não permitimos procurar para o mesmo nenhum padrão de medida adequado a ele fora dele, mas simplesmente nele. [...] Sublime é aquilo em comparação com o qual tudo o mais é pequeno." (KANT, I. Crítica da faculdade do juízo. Tradução de Valério Rohden e António Marques. Rio de Janeiro: Forense Universitária, 1993, p 95-6).

33 "Dizemos dum canto de canário que é jovial, dum canto de graúna que é triste, dum sabiá que é ardente ou melódico." (ANDRADE, M. Introdução à estética musical. Pesquisa, estabelecimento de texto, introdução e notas por Flávia Camargo Toni. São Paulo: Hucitec, 1995, p 43)
} 
hora do renascimento, já que o poeta, antes dilacerado e sacudido por embates, é regulado e organizado - tem o organismo constituído - pela música que ressoa na tarde vasta.

Mário de Andrade discorre sobre as influências da música no corpo do ouvinte, no texto Introdução à estética musical, preparado, a partir de 1925, com base em anotações do estudioso para aulas do curso de Estética da Música, do conservatório, e de aulas particulares que ministrava em sua casa ${ }^{34}$. Em seu texto, ao falar sobre o ritmo, Mário, baseando-se em diferentes estudiosos, aponta a sua origem fisiológica, já que nosso corpo pulsa por meio de movimentos repetitivos, como a circulação do sangue, a respiração ou o bater do coração ${ }^{35}$, afirmando, ainda, que "a percepção de qualquer série exterior de golpes ou de movimentos repetidos afeta-nos a cenestesia" ${ }^{36}$, como acontece, no poema, em que o grito ritmado das graúnas, ao lado do ronco do motor do carro, aplacam o sangue e o ofego (a circulação e a respiração) do poeta, regulando o seu ser vibrante. Sendo "Louvação da tarde" um poema itinerante em que "o emissor do discurso se movimenta" e em que está presente a "função poética da marcha, o corpo em movimento servindo para espertar a mente" ${ }^{37}$, como nos lembra Candido, o ritmo regular do organismo que se move entregue ao andar da "maquininha" influencia o andamento dos pensamentos do poeta e, portanto, seus versos, marcados pelo andar do forde e pela batida dos gritos da graúna. Como diz Mário, "todo ritmo organiza pois a atividade vital. A expressão é uma atividade vital. Se a gente a organiza, [...] a gente artefaz a expressão pois que a arte não é mais do que uma expressão organizada, [...] dá-lhe um ritmo." 38

Os primeiros dez versos, início da introdução da "Louvação", são formados por um período que se estende longamente como se traduzisse, por meio da idéia que demora a se completar, a sensação do eu poético frente à tarde vasta e vagarosa. O poema é formado pela alternância entre aglomerados longos de versos, como as dez primeiras linhas, e por momentos compostos por unidades ínfimas, em que aparecem versos divididos por pausas internas ou, ainda, idéias completas em apenas uma linha. Antonio Candido vê nessa alternância uma "maneira folgada de usar o decassílabo", já que, dentro do esquema métrico

\footnotetext{
${ }^{34}$ Os textos, abandonados pelo escritor, foram retomados por Flávia Camargo Toni, que organizou e publicou o livro.

${ }^{35}$ ANDRADE, M. Introdução à estética musical. Pesquisa, estabelecimento de texto, introdução e notas por Flávia Camargo Toni. São Paulo: Hucitec, 1995, p 71.

${ }^{36}$ Ibidem, p 71.

${ }^{37}$ CANDIDO, A. Op. cit., p 261.

${ }^{38}$ ANDRADE, M. Introdução à estética musical. Pesquisa, estabelecimento de texto, introdução e notas por Flávia Camargo Toni. São Paulo: Hucitec, 1995, p 72.
} 
rígido, "o ritmo e o vocabulário são os da prosa familiar, bem próximos do dia-a-dia, distantes da solenidade que o metro poderia sugerir". A modernidade do poema, de acordo com o estudioso, fica evidente na forma liberta de se usar um esquema de versos tradicional ${ }^{39}$. Além de despojar o decassílabo erudito da aura de tradição, mostrando-se à vontade ao construir um improvisado solilóquio por meio de uma entoação de fala livre, combatendo, assim, a armadura métrica, o poeta alterna a fala cotidiana com momentos mais rebuscados, em uma mistura de estilos - a construção esmerada de "só tu me desagregas tarde vasta", por exemplo, contrasta com o prosaico "da minha trabalhadeira" (versos 11 e 12), assim como "essa que sendo minha, nos traria/ uma vida de blefe" é cortado pelo estridente "quá! quá! quá!...” (versos 79, 80 e 83).

Como afirma Antonio Candido, a meditação de "Louvação da tarde" é da mais completa modernidade, já que o poeta não percorre a estrada caminhando ou a cavalo, como nos poemas românticos, mas montado num automóvel, entroncando, dessa forma, a meditação itinerante na era da mecanização. No entanto, apesar de ser um objeto moderno, a "maquininha" "como verdadeiro figurante de poesia lírica romântica é doce, meig[a], lent[a], assimilad[a] a um animal integrado no ritmo da natureza", diferente das máquinas velozes exaltadas pelos futuristas ${ }^{40}$. O forde aparece, em "Louvação da tarde", de forma diferente da "fordeca" que, no poema "Lenda do céu", de Clã do jabuti (1927), “chispava", em alta velocidade, pelos varjões, retratando, por meio do contraste com o aboiar lento dos boiadeiros ${ }^{41}$, a imagem contraditória do Brasil. No poema de Remate de Males (1930), início de uma fase mais madura de Mário de Andrade, o "doce respirar do forde" não se opõe aos gritos da graúna, mas compõe, ao lado do cantar do pássaro, o ritmo que regula o pulso do poeta.

Definida por meio de uma enumeração de adjetivos - incomensurável, vasta, vazia, pálida, doente, tardonha - a tarde é, acima de tudo, "Imóvel... quase imóvel”, tempo mítico que permite ao poeta se distanciar do cotidiano profano, a fim de renascer organizado pelos ritmos da graúna e do forde.

Tarde, recreio de meu dia, é certo Que só no teu parar se normaliza

\footnotetext{
${ }^{39}$ CANDIDO, A. Op. cit., p 259-60.

${ }^{40}$ Ibidem, p 265-7.

41 "Lá pelo varjão se ouvia/ Duma fordeca a chispada,/ E no meio-dia quente/ Amulegando maneiro/ Um aboio tão chorado/ Que acuava no corpo doce/ O sono do brasileiro.” (ANDRADE, M. Poesias completas. Edição crítica de Diléa Zanotto Manfio. Belo Horizonte: Villa Rica, 1993, p 195). Cf. SOUZA, C. R. Clã do jabuti: uma partitura de palavras. São Paulo: Annablume; FAPESP, 2006, p 143-4.
} 
A onda de todos os transbordamentos

Da minha vida inquieta e desregrada.

Só mesmo distanciado em ti, eu posso

Notar que tem razão-de-ser plausível

Nos trabalhos de ideal que vou semeando

Atabalhoadamente sobre a Terra.

Só nessa vastidão dos teus espaços,

Tudo o que gero e mando, e que parece

Tão sem destino e sem razão, se ajunta

Numa ordem verdadeira.... Que nem gado,

Pelo estendal do jaraguá disperso,

Ressurge de tardinha e, enriquecido

Ao aboio sonoro dos campeiros,

Enriquece o criador com mil cabeças

No circo da mangueira rescendente...

Somente na imobilidade da tarde - no intervalo de tempo -, o eu lírico pode descobrir a "razão-de-ser" de seus trabalhos diários, reunindo numa ordem compreensível os transbordamentos e ações semeados de forma confusa durante o dia. $\mathrm{O}$ ajuntar do gado que, disperso pela superfície extensa dos campos de capim-jaraguá, retorna à tardinha, sob o toque dos aboios, é similar ao organizar da vida inquieta do poeta dividido que ressurge unificado renascido - ao som do aboio entoado pelo forde e pela graúna, na vastidão da tarde. A descrição da ordenação dos bois é realizada em seis versos não interrompidos por pontos finais, leitura que se estende, em um decrescendo, até ser finalizada pela palavra "rescendente" (recendente), em pianíssimo, acompanhada por reticências.

Os termos "estendal" e "jaraguá", empregados no trecho acima, guardam outros significados que, se levados em conta, reforçam a idéia de ressurreição do poeta dividido. $\mathrm{O}$ Pico do Jaraguá (em tupi, senhor do vale) é o ponto mais alto de São Paulo, cidade em que o poeta - o boi sacrificado - se dispersou em "Amar sem ser amado, ora pinhões!" - "Me esparramo pela cidade" ${ }^{42}$, metrópole que constitui o estendal (superfície extensa) avistado longamente de cima do monte. Além disso, Jaraguá é o nome de um dos personagens fantásticos do Bumba, bailado que representa a morte e o renascimento do boi ${ }^{43}$.

\footnotetext{
${ }^{42}$ No poema de Lira paulistana em que o poeta mostra o desejo de ser dividido após sua morte, como o boi sacrifical, o Pico do Jaraguá é o lugar escolhido para serem depositados seus olhos - "Os olhos lá no Jaraguál Assistirão ao que há-de vir". (ANDRADE, M. Poesias completas. Edição crítica de Diléa Zanotto Manfio. Belo Horizonte: Villa Rica, 1993, p 381).

${ }^{43}$ De acordo com Câmara Cascudo, a fantasia do personagem Jaraguá é feita com uma "armação de madeira em forma de boi, coberta de tecido florido" (CASCUDO, L. C. Dicionário do folclore brasileiro - edição ilustrada. São Paulo: Global, 2002, p 291). Mário de Andrade recolheu a melodia da dança do Jaraguá como parte do Bumba-meu-boi do Rio Grande do Norte - "Chegô, chegô,/ Meu Jaraguá,/ U bichinho é bunitinho,/ Ele sabe vadiá!" (ANDRADE, M. Danças Dramáticas do Brasil. Edição organizada por Oneyda Alvarenga. Belo Horizonte: Itatiaia, 2002, p 616).
} 
A calma do momento vespertino possibilita a entrega do poeta a devaneios, já que o afasta de suas obrigações diurnas, não preteridas, no entanto, por ele, que valoriza a agitação dos afazeres diários. Mesmo não negando o prazer sentido durante a ação do dia, o eu lírico afirma amar as cores incertas da tarde que lhe possibilitam a invenção de uma outra vida, mais perfeita, sem dores ou inquietações. Dessa forma, um diálogo íntimo - dramático - entre as disposições contrastantes do poeta se estabelece por meio da oposição entre manhã e tarde, como podemos notar nos versos seguintes.

Tarde macia, pra falar verdade:

Não te amo mais do que a manhã, mas amo

Tuas formas incertas e estas cores

Que te maquilham o carão sereno.

Não te prefiro ao dia em que me agito,

Porém contigo é que imagino e escrevo

$\mathrm{O}$ rodapé do meu sonhar, romance

Em que o Joaquim Bentinho dos desejos

Mente, mente, remente impávido essa

Mentirada gentil do que me falta.

Um despropósito de perfeições

Me cerca e, em grata sucessão de casos,

Vou com elas vivendo uma outra vida:

Antonio Candido relaciona o penúltimo poema de Tempo da Maria, escrito em junho de 1924, a outras duas composições poéticas de Mário de Andrade: "Louvação matinal", redigida em 1925, e “A meditação sobre o Tietê", terminada ao final da vida do poeta. O estudioso mostra as diferentes funções das horas do dia e da noite nos poemas: a manhã é o momento de luta consciente, em que a razão impulsiona o trabalho; a noite, de "A meditação sobre o rio Tietê", é a hora em que vêm à tona os desejos inconscientes irregulares e recalcados pela sociedade; e o entardecer, de "Louvação da tarde", é o momento de entrega à fantasia, descanso em que a imaginação segue livremente o próprio curso, numa tentativa de alcançar a paz interior. ${ }^{44}$ Dessa forma, "Louvação" constitui, assim como as loas populares, a hora do descanso entre os bailados das danças dramáticas ${ }^{45}$, momento em que o "Joaquim Bentinho $^{46}$ dos desejos/ mente, mente, remente impávido essa/ mentirada gentil" que compõe os devaneios do poeta, iniciados a partir do verso 59 do poema de Tempo da Maria,

\footnotetext{
${ }^{44}$ CANDIDO, A. Op. cit., p 268.

45 ANDRADE, M. Dicionário musical brasileiro. Coordenação de Oneyda Alvarenga, 1982-84, e de Flávia Camargo Toni, 1984-89. Belo Horizonte: Itatiaia, 1999, p 288.

${ }^{46}$ Antonio Candido lembra-nos que Joaquim Bentinho é o personagem mentiroso do livro de Cornélio Pires, Estrambóticas aventuras de Joaquim Bentinho, o queima campo (1925), ao qual os leitores da época estavam familiarizados (CANDIDO, A. Op. cit., p 271).
} 
revelando, por meio da entrega do eu lírico à fantasia, o esforço do eu sacrificial para renascer organizado.

O poeta de "Louvação da tarde" entrega-se a fantasias com as quais escreve o "rodapé de [seu] sonhar", somente após ter sentido o "papagaio louro do ventinho" em sua mão. Confirmando o caráter cíclico dos poemas de Tempo da Maria, um tempo mítico que sempre retorna, o vento, símbolo do ciclo da natureza, dispersa o eu lírico de "Amar sem ser amado, ora pinhões!" por Paulicéia, em uma morte simbólica e, em "Louvação da tarde", está presente no momento de regeneração ${ }^{47}$, similar, dessa forma, ao vento invocado pelo poeta inglês Shelley, em Ode to the West Wind (Ode ao Vento do Oeste). No entanto, o eu lírico do poema modernista não é tocado por um vento poderoso e incontrolável como o vento do poeta romântico, mas por um "ventinho", diminutivo típico da fala brasileira que estabelece uma relação carinhosa entre o eu lírico e a força natural ${ }^{48}$.

Percy Bysshe Shelley é lembrado, por Mário de Andrade, no poema de fechamento de Tempo da Maria, em que a dona casada segura um livro do poeta romântico similar ao belíssimo exemplar da biblioteca particular do poeta modernista ${ }^{49}$ - "É Shelley que está na moda,/ E as mãos dela sobre a capa/ Da edição de Oxford, orvalham/ O couro negro macio" 50 . Em "Ode ao vento do Oeste", o poeta romântico louva o vento preservador e destruidor que, relacionado ao ciclo da natureza, é o espírito indomável que causa a destruição na terra, no céu e na água, durante o outono, para que possa haver o renascimento na primavera. "Vento", que significa, em várias línguas, fôlego, alma e inspiração, é o responsável, no poema de Shelley, por vários ciclos de morte e regeneração - da vegetação, do humano e do divino. ${ }^{51} \mathrm{O}$ vento de "Ode ao Vento do Oeste" é a inspiração que faz do poeta sua lira eólica, tirando dele sons outonais assim como tira da floresta o canto fúnebre e triste ao passar por meio de suas árvores que, no outono, estão perdendo as folhas - "Faz-me tua lira, assim como a floresta é:/ E se minhas folhas estiverem caindo como as dela!/ O tumulto das tuas

\footnotetext{
${ }^{47}$ A voz lírica de "Carnaval carioca" (Clã do jabuti) entrega-se ao ritmo buliçoso do povo após ser tomado pelo vento - "puxou-me a ventania" -, impregnando seu discurso erudito com os calores, as sensualidades e o tom da fala brasileira, como se vivenciasse um rito iniciático. Cf. SOUZA, C. R. Festa profana. In: Clã do jabuti: uma partitura de palavras. São Paulo: Annablume; FAPESP, 2006.

48 "Você já reparou que o diminutivo brasileiro ainda é mais carinhoso que o português? Eu creio que isso nos veio do fundo amoroso do negro". ANDRADE, M. Cartas a Manuel Bandeira. Rio de Janeiro: Edições de Ouro, 1967, p 71-2.

${ }^{49}$ SHELLEY, P. B. The complete poetical Works of Percy Bysshe Shelley. London: Humphrey Milford, Oxford University Press, 1917.

${ }^{50}$ ANDRADE, M. Poesias completas. Edição crítica de Diléa Zanotto Manfio. Belo Horizonte: Villa Rica, 1993, p 242.

${ }^{51}$ The Norton Anthology of English Literature, $5^{\text {th }}$ edition, 1962, p 1746.
} 
poderosas harmonias// Irá tirar de ambos um profundo, outonal tom,/ Doce embora triste" 52 . A fim de apressar seu renascimento, o eu lírico do poema romântico pede ao vento que espalhe, pelo universo, seus pensamentos extintos, secos como folhas de árvores, dispersando, como cinzas e faíscas de uma fornalha, suas palavras pela humanidade.

O vento que aparece, nos poemas românticos, como a inspiração ou o inconsciente, sugeriu a Mário de Andrade a palavra seqüestro, derivada do termo "refoulement", usado, pela primeira vez pelo estudioso, para descrever uma fotografia de roupas infladas pelo vento no varal, sugerindo $\operatorname{corpos}^{53}$. O seqüestro, palavra que funde os termos repressão e sublimação, usados por Freud, é posto em ação em "Louvação da tarde", em que o poeta, após ser tocado pelo vento, é levado a imaginar uma vida perfeita, construindo, por meio de fantasias, um refúgio no qual poderia escapar dos dilemas do amor não correspondido. A tentativa de sublimar, por meio do canto, o amor pela dona casada, anunciada no poema de abertura "Moda do corajoso", sofreu, nos poemas posteriores, os golpes causados pelo arrebatamento sensual da voz lírica, tomada por lembranças amorosas. Em "Louvação da tarde", o poeta, como a criança que brinca, "cria um mundo de fantasia [...] no qual investe uma grande quantidade de emoção" ${ }^{44}$, no qual poderá se refugiar - "Adeus! vou-me embora!" 55.

...Toda dor física azulou... Meu corpo,

Sem artritismos, faringites e outras

Específicas doenças paulistanas,

Tem saúde de ferro. Às intempéries

Exponho as ondas rijas dos meus músculos,

Sem medo. Pra que medo!... Regulares,

Mais regulares do que os meus, os traços

Do meu rosto me fazem desejado

Mais facilmente que na realidade...

Já não falo por ela não, por essa

Em cujo perfil duro jaz perdida

A independência do meu reino de homem... 70

Que bonita que ela é!... Qual!... Nem por isso.

Não sonho sonhos vãos. A realidade,

Mais esportiva de vencer, me ensina

Esse jeito viril de ir afastando

Dos sonhos vesperais os impossíveis

\footnotetext{
52 "Make me thy lyre, even as the forest is:/ What if my leaves are falling like its own!/ The tumult of thy mighty harmonies/ Will take from both a deep, autumnal tone,/ Sweet though in sadness.” Ibidem, p 1748.

53 "Foto e legenda M. A.: 'Roupas Freudianas/ Fortaleza/ 5-VII-27/ Fotografia refoulenta/ Refoulement" LOPEZ, T. P. Mário de Andrade: ramais e caminhos. São Paulo: Duas Cidades, 1972, p 79; 106.

${ }^{54}$ FREUD, S. Escritores criativos e devaneios. In: Obras psicológicas completas de Sigmund Freud. Rio de janeiro: Imago, 1967, v 9, p 135.

${ }^{55}$ Verso de "Cantiga do ai".
} 
Que fazem a quimera, e de que a vida

É nua, friorentamente nua.

Não a desejo não... Viva em sossego

Essa que sendo minha, nos traria

Uma vida de blefe, arrebatada

Por mais estragos que deslumbramentos.

Isto, em bom português, é amor platônico...

Quá! quá! quá!... Desejemos só conquistas!

Um poder de mulheres diferentes,

Meninas-de-pensão, costureirinhas,

Manicuras, artistas, datilógrafas,

Brancaranas e louras sem escândalo,

Desperigadas... livro de aventuras

Dentro do qual secasse a imagem da outra,

Que nem folha de malva, que nem folha 90

De malva... da mais pura malva perfumada!...

O andamento de "Louvação da tarde" é calmo e comedido. No entanto, como que contidos pelo discurso moderado, desejos e vibrações do poeta transparecem em certos momentos dos devaneios, sendo rapidamente acalmados pela voz lírica que se esforça para conseguir a sublimação da paixão e seu apaziguamento. Se em "Amar sem ser amado, ora pinhões!" o poeta coloca em cena os dilemas, mostrando sua indecisão entre a sublimação do amor e o arrebatamento sensual, em "Louvação", os choques, que causaram tanta variação de andamento no segundo poema de Tempo da Maria, são apenas entrevistos, formando pequenas tremulações na música do poema, rapidamente contidas e abandonadas.

Iniciado por reticências que circundam a frase “...Toda dor física azulou...", sinalizando divagações anteriores, o primeiro devaneio de "Louvação da tarde" apresenta um eu lírico possuidor de um corpo físico saudável e forte, resistente a quaisquer doenças paulistanas que tanto amolaram Mário de Andrade. No mundo perfeito da fantasia, o corpo do poeta possui "ondas rijas de músculos" e seu rosto é formado por traços equilibrados, sendo, bem-proporcionado, mais atraente do que na realidade. No entanto, ao vivenciar uma fantasia na qual todas as perfeições inexistentes na realidade são desejadas, ficam implícitas as imperfeições reais. Contidos, os sentimentos mais íntimos do eu lírico são mostrados de forma sutil por meio de uma dor que se pode apreender nas entrelinhas da narração fantasiosa, em que desejos impossíveis são colocados como possíveis. Falar de perfeições físicas, na fantasia, sempre sujeita o eu à volta à realidade áspera. Assim, mostrar, corajosamente, nos versos, o desejo de beleza é assumir a realidade de não ser desejado fisicamente e a dor que 
possa nascer dessa fatalidade. Compreender essa dor é apreender o lirismo contido do poema, do qual Mário falou em carta a Manuel Bandeira ${ }^{56}$.

Ao falar da atração que pode exercer, na fantasia, sobre as mulheres, o poeta é tomado pela imagem da amada, "essa/ Em cujo perfil duro jaz perdida/ A independência [de seu] reino de homem”. A volta do verso "Que bonita que ela é!...”, refrão de Tempo da Maria, invoca o mal de amor que percorre os poemas do grupo, constituindo o titubear do eu lírico que corre o risco de se entregar, novamente, aos dilemas do amor impossível. No entanto, o poeta afasta, de forma viril, os sonhos impossíveis dos vesperais - "Qual!... Nem por isso" -, pois sabe que a vida real não comporta fantasias - quimeras. Ao afirmar que "Não a desej[a] não...", o eu lírico tenta conter a lembrança incômoda da mulher sublime que atrapalha o devaneio em que ele se sente capaz de conquistas: costureirinhas, manicuras, datilógrafas, classe proletária acessível e "desperigada" que formaria o livro de aventuras no qual, finalmente, poderia ser arquivada, como folha de malva, a aristocrática Maria. No entanto, o perfume da malva, flor rosada como a tarde e como a amada, invade o poeta como um eflúvio impossível de ser retido - "da mais pura malva perfumada!...”. As pequenas oscilações entre fantasias repletas de conquistas e a lembrança do amor irrealizado formam os titubeios musicais do primeiro devaneio, pontuados na diversidade de ritmos e andamento.

A lembrança da dona ausente, invocada ternamente por meio da repetição que fecha a estrofe - "que nem folha de malva, que nem folha/ De malva..." -, ao se impor ao poeta como um perfume irresistível, é abandonada por ele, de forma deliberada, já que teme sucumbir ao apelo do desejo. Ao deixar a estrofe em aberto, partindo, no bloco de versos seguinte, para a construção de um novo devaneio, a primeira fantasia é suspensa sem conclusão, como se o final da divagação, ao atingir o alto grau de tensão provocado pela lembrança de Maria, ficasse sem resolução, abandonado de forma proposital pelo poeta, como um período musical finalizado antes do acorde de fechamento. Usando termos musicais para descrever a sensação causada pelo abandono do devaneio, podemos dizer que a quarta estrofe é terminada por uma "cadência interrompida" ou uma "cadência imperfeita", como se um acorde dominante ou submediante, que dão a impressão de que o período está incompleto, aguardando por uma conclusão, aparecesse no lugar do esperado acorde tônico que concluiria a música, em uma "cadência perfeita" ${ }^{57}$, dando a sensação de acabamento ${ }^{58}$

\footnotetext{
${ }^{56}$ ANDRADE, M. apud CANDIDO, A. Op. cit., p 258-9.

${ }^{57}$ KAROLYI, O. Harmonia e contraponto. In: Introdução à música. São Paulo: Martins Fontes, 1990, p 78-81.

${ }^{58}$ Charles Rosen discorre sobre uma das formas de fragmento usadas pela primeira geração de músicos românticos: uma peça sem final conclusivo com "uma simples dissonância tal como um acorde de sétima de
} 
O devaneio sem resolução lembra-nos, ainda, das inúmeras peças musicais da tradição popular brasileira terminadas na sensível, estudadas por Mário de Andrade. Maurício de Carvalho Teixeira, em sua tese de doutorado, mostra a preocupação do modernista em estudar uma das constâncias melódicas da nossa música, a saber, a "terminação na sensível” finalização de peças musicais "a meio-tom da nota fundamental, [...] [criando] um final suspensivo que [...] deixa em todos a sensação física de que a música não acaba definitivamente" 59 . Dessa forma, o final inconcluso do primeiro devaneio de "Louvação da tarde" pode ser entendido, também, como a recuperação de um dos elementos populares próprio da estética musical do Brasil.

Após abandonar o primeiro devaneio, retomando a criação de fantasias na estrofe seguinte, o poeta volta a buscar um andamento regular para sua composição.

Livre dos piuns das doenças amolantes,

Com dinheiro sobrando, organizava

As poucas viagens que desejo... Iria

Viajar todo esse Mato Grosso grosso,

Danado guardador da indiada feia,

E o Paraná verdinho... Ara, si acaso

Tivesse imaginado no que dava

A Isidora, não vê que ficaria

$\mathrm{Na}$ expectativa pança em que fiquei!

Revoltoso banzando em viagens tontas,

Ao menos o meu sul conheceria,

Pampas forraginosos do Rio Grande

E praias ondejantes do Iguaçu...

Tarde, com os cobres feitos com teu ouro, 105

Paguei subir pelo Amazonas... mundos

Desbarrancando, chãos desbarrancados,

Aonde no quiriri do mato brabo

A terra em formação devora os homens...

Este refrão dos meus sentidos... Nada

Matutarei mais sem medida, ôh tarde,

Do que esta pátria tão despatriada!

No esforço de construir uma vida perfeita, por meio de devaneios, aqui, mais próximos dos aspectos materiais e limites financeiros da vida do poeta, o eu lírico imagina-se "com dinheiro sobrando", capaz de realizar viagens pelo interior do Brasil, sem ser amolado,

dominante para finalizar" ou, ainda, com uma "cadência final [...] com um acorde de tônica e, mesmo assim, transmiti[ndo] um sentido de uma sutil ambigüidade final" (ROSEN, C. A geração romântica. Trad. de Eduardo Seincman. São Paulo: EDUSP, 2000, p 129; 132). Dessa forma, os devaneios de "Louvação da tarde" podem ser entendidos como fragmentos incorporados ao texto.

${ }^{59}$ TEIXEIRA, M. C. Torneios melódicos: musicalidade e musicologia em Mário de Andrade. Tese de doutoramento em preparação (defesa prevista para 2007). Orientação do Prof. Dr. José Miguel Wisnik. FFLCH USP, 2007, p 9. 
inclusive, por doenças tropicais e pelos "piuns", borrachudos que infernizam as viagens por nossas matas, citados por Koch-Grünberg, ao narrar sua travessia pelo interior do país "Aqui, fervilham os piuns, esses miseráveis sugadores diurnos" 60.

Como nos lembra Lafetá, os anos vinte são marcados por um espírito revolucionário que dita a necessidade de se desbravar o interior do país, a fim de se entrar em contato com a diversidade da gente brasileira. ${ }^{61}$ Em "Louvação da tarde", o poeta, em seu devaneio, seguindo o desejo de conhecer o Brasil, sonha poder viajar pelo país, disposto, até mesmo, a seguir o deslocamento da coluna Prestes, marcha que foi a consequiência da "Isidora", Revolução de 1924 comandada pelo General Isidoro Dias Lopes. Lembrando a analogia de Lafetá, que compara a marcha da coluna com a "descoberta do Brasil" realizada pelos modernistas $^{62}$, o desejo do poeta de seguir os revoltosos pelo interior de sua terra reafirma a necessidade de compreender a pátria imensa e desconhecida.

\begin{abstract}
Este Brasil monstruoso, tão esfacelado, tão diferente, sem nada nem siquer ainda uma língua que ligue tudo, como é que a gente o pode sentir íntegro, caracterizado, realisticamente? Fisicamente? Enquanto me penso brasileiro [...] e trabalho e amo que nem brasileiro, me apalpo e me parece que sou maneta, sem um poder de pedaço de mim, que não posso sentir embora meus, que estão no mistério, que estão na idealização [...] É horrível. Doloroso. ${ }^{63}$
\end{abstract}

Em “Louvação da tarde", a viagem à Amazônia, realizada em 1927 por Mário de Andrade, invade o segundo devaneio, lembrança que, de acordo com Antonio Candido, mostra o retoque do texto antes de sua publicação, já que foi escrito dois anos antes da excursão de Mário de Andrade ${ }^{64}$. Candido nos lembra, ainda, como a Amazônia corresponde, no poema, aos impulsos primitivos do poeta e da cultura brasileira, já que é lugar "onde a terra se confunde com a água, o mato grosso esconde tudo e a criação parece inacabada", fazendo o poeta pensar no Brasil inteiro, também impreciso e ambíguo ${ }^{65}$. Gilda de Mello e Souza, no texto "O mestre de Apipucos e o turista aprendiz", mostra, ao citar carta de Mário de Andrade a Manuel Bandeira, escrita durante sua travessia pelo rio Amazonas, o "êxtase" e

\footnotetext{
${ }^{60}$ KOCH-GRÜNBERG, T. Do Roraima ao Orinoco, v. 1: observações de uma viagem pelo norte do Brasil e pela Venezuela durante os anos de 1911 a 1913. Tradução de Cristina Alberts-Franco. São Paulo: Editora UNESP, 2006, p 36.

${ }^{61}$ LAFETÁ, J. L. Figuração da intimidade. São Paulo: Martins Fontes, 1986, p 14.

${ }^{62}$ Ibidem, p 23.

${ }^{63}$ ANDRADE, M. Cartas de Mário de Andrade a Luis da Câmara Cascudo. Belo Horizonte-Rio de Janeiro: Itatiaia, 2000, p 35.

${ }^{64}$ CANDIDO, A. O poeta itinerante. In: O discurso e a cidade. São Paulo: Duas Cidades, 1993, p 273.

${ }^{65}$ Ibidem, p 274.
} 
a "volúpia" que tomam o viajante ao penetrar a floresta, abandonando o controle racional, frente ao sublime da natureza ${ }^{66}$. A lembrança de tema tão caro ao modernista, a saber, a necessidade de conhecer a "pátria tão despatriada" - "este refrão dos [seus] sentidos" -, assim como a recordação da entrega contemplativa que o tomou frente à grandeza amazônica, faz com que o poeta, no segundo devaneio, seja invadido por intensa vibração, rompendo novamente o andamento da "Louvação da tarde".

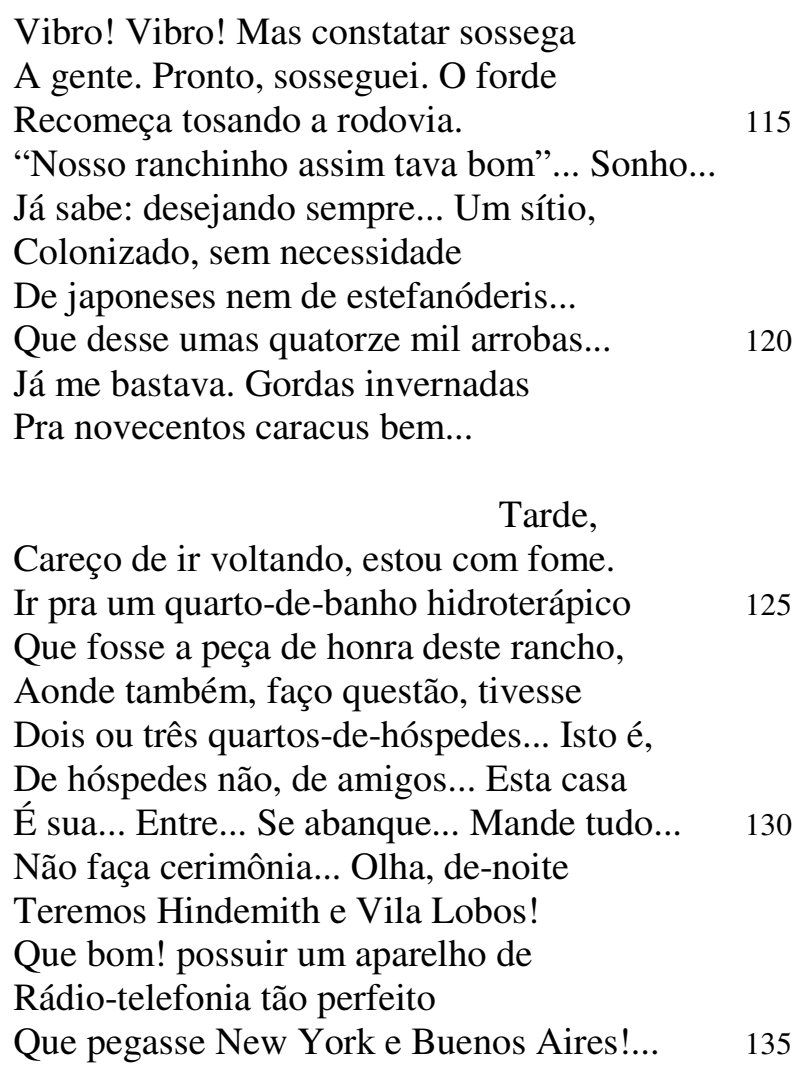

No início da sexta estrofe, o eu lírico constata a comoção que, quebrando o andamento calmo do forde, toma seu corpo - "Vibro! Vibro!". Somente após a verificação racional de sua exacerbação emocional, o poeta consegue retomar o ritmo calmo da maquininha que recomeça a tosar a rodovia, compasso que dita o andamento de "Louvação da tarde" - "Mas constatar sossega/ A gente. Pronto, sosseguei. O forde/ Recomeça tosando a rodovia”. Se, no primeiro devaneio, a tensão criada pela lembrança de Maria fica sem resolução, como um fragmento musical finalizado por meio de um acorde "dominante", na segunda fantasia, a angústia causada pela vibração do eu lírico ao se lembrar da "pátria despatriada" é resolvida

\footnotetext{
${ }^{66}$ SOUZA, G. M. O mestre de Apipucos e o turista aprendiz. Teresa revista de Literatura Brasileira/ área de Literatura Brasileira. Departamento de Letras Clássicas e Vernáculas. FFLCH. USP - n. 1 (1ºm. 2000). São Paulo: ed 34, 2000, p 80.
} 
por meio da constatação - "Pronto, sosseguei." - equivalente a um acorde tônico que finaliza a peça musical.

Ao recomeçar a acelerar o forde, o poeta deixa-se embalar novamente pelo ritmo da maquininha, retomando os devaneios. Em sua última fantasia, o eu lírico deseja ser dono de um ranchinho, uma casa pobre da roça, logo transformado pela imaginação em sítio próspero, com cafezais que se desenvolvem mesmo sem a mão de obra dos imigrantes japoneses e sem a atuação da vespa stephanoderis, controle biológico da broca-do-café. O sítio desejado possui ainda grandes invernadas - pastagens em que se reúne o gado, antes disperso, para o repouso e o recobrar de forças - onde caberiam novecentas cabeças bovinas. Se em "Amar sem ser amado, ora pinhões!", o eu lírico é o "farrancho" multiplicado que se espalha por Paulicéia, em "Louvação", o devaneio do poeta, que sonha em ter um "ranchinho" cercado por invernadas em que se reúne o gado, revela o desejo de unificação.

No início da sétima estrofe (versos 123 e 124), o poeta, por um momento, abandona o devaneio, ao sentir fome, uma necessidade imediata da vida real. No entanto, como que tomado pelo balanço do forde, o eu lírico volta a sonhar com seu rancho, casa ideal possuidora de confortos avançados para o tempo: quarto-de-banho hidroterápico e aparelho de radiofonia capaz de captar a música que se toca em outros países - Villa-Lobos e Hindemith $^{67}$. A casa desejada, além disso, é repleta de quartos-de-hóspedes, pronta para reunir os amigos, recebendo-os com o calor e o acolhimento próprios do brasileiro - "E em todas as moradias/ que se erguem no chão quentinho/ do nosso imenso Brasil,/ não tem uma que não tenha/ um quarto-de-hóspede pronto!" ${ }^{68}$. No último devaneio, sem que o andamento do forde e dos versos tenha sido interrompido por anseios amorosos ou pela lembrança da pátria despatriada, o poeta consegue atingir a pacificação que vinha perseguindo em seu passeio pela tarde, ao sonhar com o ranchinho, refúgio perfeito - "vou-me embora".

Após os três devaneios centrais, a louvação do início é retomada pelo poeta.

\footnotetext{
${ }^{67} \mathrm{O}$ compositor brasileiro citado no poema realiza, em suas peças, um tipo de mistura similar à empreendida por Mário de Andrade em "Louvação da tarde". Se o poeta modernista se utiliza do metro erudito de maneira "folgada", assimilando traços populares à tradição, Villa-Lobos (1887-1959) veicula elementos populares por meio de uma linguagem erudita, utilizando-se ainda de recursos típicos do século XX, como afirma Bruno Kiefer. Nas Bachianas, por exemplo, processos singulares da nossa música são recriados sob a atmosfera de Bach (KIEFER, B. Villa-Lobos e o modernismo na música brasileira. Porto Alegre: Movimento; Brasília: INL: Fundação Nacional Pró-Memória, 1986, p 46; 111 e 114). O compositor alemão Paul Hindemith (1895-1963) também justapõe elementos díspares: em seu Kammermusik $n^{\circ} 1$, por exemplo, imita o estilo barroco ao mesmo tempo em que dispõe de elementos modernos, como recursos do jazz (The Grove Concise Dictionary of Music, disponível em http://w3.rz-berlin.mpg.de/cmp/hindemith.html). Além disso, assim como Mário de Andrade exalta a amada Maria, sublime e santa, ambos compuseram peças tendo como tema a mãe de Jesus: Villa-Lobos escreveu inúmeras Ave-Marias e Hindemith compôs Das Marienleben (vida de Maria), ciclo de canções baseado em poema de Rainer Maria Rilke.

${ }^{68}$ Versos de "Lenda das mulheres de peito chato".
} 
Tarde de meu sonhar, te quero bem!

Deixa que nesta louvação, se lembre

Essa condescendência puxapuxa

De teu sossego, essa condescendência

Tão afeiçoável ao desejo humano.

De-dia eu faço, mas de-tarde eu sonho.

Não és tu que me dás felicidade,

Que esta eu crio por mim, por mim somente,

Dirigindo sarado a concordância

Da vida que me dou com o meu destino.

Não marco passo não! Mas si não é

Com desejos sonhados que me faço

Feliz, o excesso de vitalidade

Do espírito é com eles que abre a válvula

Por onde escoa o inútil excessivo;

Pois afastando o céu de junto à Terra,

Tarde incomensurável, me permites,

Qual jaburus-moleques de passagem,

Lançar bem alto nos espaços essa

Mentirada gentil do que me falta.

Além de permitir a livre reflexão e as livres analogias do poeta, que estruturam o poema, a "condescendência puxapuxa" do sossego da tarde, complacente em relação aos desejos do eu lírico, faz com que os sonhos idealizados - "essa mentirada gentil” - sejam atirados ao ar, como jaburus-moleques. Mário de Andrade, conhecedor de Freud, mostra o exercício da fantasia como a liberação do "inútil excessivo" dos desejos impossíveis. Em "Louvação", o poeta põe em ação o processo por meio do qual sua razão procura "sublima[r] o fogo devorador", como havia prometido em "Moda do corajoso", e, apesar do titubeio ao se lembrar do perfume da amada - da folha de malva -, talvez jamais esquecido, mas arquivado, e da vibração que o toma ao pensar na "pátria tão despatriada", o poeta se mostra, ao final do poema, aquietado pelo ritmo calmo do forde e pelo sossego vespertino - renascido. Diferente da tardinha vermelha de "Amar sem ser amado, ora pinhões!", em que "o céu se encurva sobre o chão/ num gesto forte de abraçar", momento de angústias e anseios sensuais, a tarde rosada de "Louvação" "afasta o céu de junto à Terra", permitindo a sublimação dos desejos que se perdem na imensidão.

Devaneios como os de "Louvação da tarde", fantasias motivadas por desejos, são entendidos por Freud como "uma correção da realidade insatisfatória" ${ }^{69}$. Os "sonhos" do poema são similares ao "devaneio ingênuo" de que fala o estudioso, em que o herói

\footnotetext{
${ }^{69}$ FREUD, S. Escritores criativos e devaneios. In: Obras psicológicas completas de Sigmund Freud. Rio de Janeiro: Imago, 1967, v. 9, p 137.
} 
invulnerável, o ego, protegido de descontentamentos, imagina farturas financeiras e conquistas amorosas. No entanto, "Louvação da tarde" não é feita somente por meio de transposições de fantasias, pois o poeta constrói o texto repensando-as sob a ótica freudiana, mostrando-se, dessa forma, consciente da separação entre os momentos de ação - o dia - e o momento do sonho - a tarde -, já que "de-dia [faz], mas de-tarde sonh[a]".

Assim como o devaneio é a válvula de escape que, lançando ao alto a "mentirada gentil”, previne a manifestação de doenças psíquicas, frutos da repressão aos desejos, a criação literária, de acordo com Freud, é também resultado de fantasias que são, no entanto, artisticamente trabalhadas. Como mostra o estudioso, o escritor consegue, por meio do prazer puramente estético, romper a barreira que separa os diferentes egos, fazendo com que as fantasias particulares, que normalmente seriam recebidas com indiferença ou repulsa por outra pessoa, causem prazer no leitor ${ }^{70}$. Mário de Andrade, no texto Introdução à estética musical, mostra de que maneira o artista criador vivencia uma vida idealizada que permite a criação literária.

Que é o artista criador? Não tem nenhuma diferença essencial entre ele e os outros homens do mundo. O que o distingue dos outros homens é [...] uma tal ou qual timidez que o leva [...] a se servir do Belo que é uma contemplação sem posse pra se expressar e comunicar. Pode-se também dizer que o artista ama com mais intensidade porque não realiza o seu amor. A timidez o leva à sublimação que não é mais do que a aplicação dos instintos amorosos em puras idealizações. [...] O artista destrói essa imediateza da necessidade idealizando a vida. Pois então organiza as artes que vão identificar pelo prazer estético, pelo espírito, pela contemplação sem posse em vez de desejar e possuir ou pretender possuir dentro da vida prática. [...] $\mathrm{Na}$ vida do artista se dá uma espécie de vida dupla, uma superposição de duas vidas distintas, pra não dizer diferentes. [...] $\mathrm{O}$ artista por este desdobramento de personalidade [...] tem uma vida interior mais intensa [...] ao passo que o homem comum tem uma integridade vital mais perfeita. $\mathrm{O}$ artista atinge essa integridade vital, essa aspiração de ser pela idealização, ao passo que o homem comum a realiza. $^{71}$

Desde o poema de abertura de Tempo da Maria, ao transformar a paixão e o desejo em cordas da viola de amor, o poeta está se propondo a criar artisticamente por meio da sublimação. No entanto, isso não se faz sem conflitos. Como em um rito dramático, o eu lírico de Tempo da Maria vive, canta, dança e dramatiza o mal-de-amor para, finalmente, no

\footnotetext{
${ }^{70}$ Ibidem, p 142.

${ }^{71}$ ANDRADE, M. Introdução à estética musical. Pesquisa, estabelecimento de texto, introdução e notas por Flávia Camargo Toni. São Paulo: Hucitec, 1995, p 57-8.
} 
penúltimo poema do grupo, apesar das oscilações causadas pelas lembranças da amada e do amor pelo país, se apaziguar por meio de fantasias desenvolvidas na quietude do crepúsculo. Em "Louvação da tarde", poema escrito na mesma época em que Mário de Andrade desenvolvia os textos da Introdução à estética musical, a voz lírica explicita o mecanismo criador do artista de que Mário de Andrade fala no trecho citado acima, ao criar "uma outra vida", fruto da fantasia, que, de acordo com Candido, é, além de fuga provisória do real, o momento de construção da obra literária ${ }^{72}$.

Além da idealização do desejo amoroso, a grande sublimação que o poeta realiza em Tempo da Maria é a sublimação artística, nos moldes descritos por Mário de Andrade em Introdução à estética musical.

Toda Arte é um fenômeno eminentemente social. O que leva o homem a criar artisticamente é principalmente [...] o desejo de amigo, a comunicação com os semelhantes. A isto se aplica duma maneira geral e menos propriamente sexual o que Freud determinou com o nome de sublimação. A arte é historicamente e psicologicamente uma manifestação sublimada de amizade [...] A identificação que [o artista] pretende mediatamente é com o espectador da sua obra. E essa identificação é muito mais determinante [...] pra criação que a própria identificação imediata com o objeto representado. Pode ser inconsciente. Subsiste sempre. ${ }^{73}$

O "desejo de amigo", que leva o artista a criar tendo em vista a realização, em um plano idealizado, do amor com os semelhantes, transparece no terceiro devaneio de "Louvação da tarde". Ao imaginar o "ranchinho", o poeta vivencia, no sonho, a realização do amor de amigo pretendida pelo artista ao criar a obra de arte. Em sua fantasia, o eu lírico acolhe os camaradas carinhosamente no rancho, como quem abre a casa ou, em um plano simbólico, o eu íntimo, para ser partilhada - "Esta casa/ É sua... Entre... Se abanque... Mande tudo.../ Não faça cerimônia..." - buscando, por meio do ato de se entregar amorosamente, conquistar o amor de amigo que se revela enorme na obra e na vida de Mário de Andrade. No último devaneio de "Louvação da tarde", o poeta consegue o apaziguamento não apenas por se imaginar no refúgio tranqüilo, mas por encontrar, nesse refúgio, a realização do amor tal como se dá por meio da arte.

$\mathrm{Na}$ última estrofe de "Louvação da tarde", o poeta, terminando sua viagem, assim como o entardecer, acinzentado, também está no final - "É quase noite" -, retorna à fazenda.

\footnotetext{
${ }^{72}$ CANDIDO, A. O poeta itinerante. In: O discurso e a cidade. São Paulo: Duas Cidades, 1993, p 277.

${ }^{73}$ ANDRADE, M. Introdução à estética musical. Pesquisa, estabelecimento de texto, introdução e notas por Flávia Camargo Toni. São Paulo: Hucitec, 1995, p 55-6.
} 
Ciao, tarde. Estou chegando. É quase noite.

Todo o céu já cinzou. Dependurada

Na rampa do terreiro a gaiolinha

Branca da máquina "São Paulo" inda arfa,

As tulhas de café desentulhando.

Pelo ar um lusco-fusco brusco trila,

Serelepeando na baixada fria.

Bem no alto do espigão, sobre o pau seco,

Vem um carancho, se empoleira a Lua,

- Condescendente amiga das metáforas...

Iniciada por versos marcados por pausas - "Ciao, tarde. Estou chegando. É quase noite./ Todo o céu já cinzou." -, a última estrofe sinaliza, por meio do ritmo quebrado, o final da viagem. Terminando a "Louvação", o poeta despede-se da tarde, assim como os cantadores dos ranchos populares entoam seus cantos de despedida ao deixarem a casa em que realizaram a dança dramática - "Meus senhores e senhoras,/ Despedida de Belém,/ Despedida, despedida,/ Até para o ano que vem" $!^{74}$. Como lembra Mário de Andrade, a expressão "vou chegando" é utilizada pelo homem do povo com o significado de "vou partir" 75. Assim, o poeta dá a despedida não apenas por meio do adeus italiano - "ciao" -, mas também pela expressão popular "estou chegando" - estou indo embora - que, em duplo sentido, indica ainda o retorno à fazenda em que o motorista do forde pode avistar a máquina de beneficiar café "São Paulo" ainda arfando como animal de trabalho.

O "lusco-fusco brusco", trinado ${ }^{76}$ que ornamenta a música calma de "Louvação da tarde" por meio da alternância rápida de notas repetidas (us - co/ us - co/ us - co), desenha na baixada fria o serelepear buliçoso e repentino das últimas luzes do crepúsculo. No alto do espigão, "a velha lua romântica de sempre que sanciona o devaneio, porque favorece a transformação da realidade pela poesia" ${ }^{77}$, como afirma Candido, se empoleira como gavião - carancho - , no pau seco, reafirmando o tempo cíclico que percorre as danças dramáticas de Tempo da Maria, já que, como lembra Mielietinski, citando Cassirrer, "na concepção mítica [...], os astros celestes tornam-se a marca do tempo, da periodicidade, da ordem universal e do destino. O tempo dá à existência caráter regulador e ordenador". ${ }^{78}$ Ao avistar o disco lunar, o

\footnotetext{
${ }^{74}$ ANDRADE, M. Danças dramáticas do Brasil. Edição organizada por Oneyda Alvarenga. Belo Horizonte: Itatiaia, 2002, p 638.

${ }^{75}$ Ibidem, p 49.

${ }^{76}$ Ornamento que consiste na articulação rápida e alternada de duas notas consecutivas.

${ }^{77}$ CANDIDO, A. O poeta itinerante. In: O discurso e a cidade. São Paulo: Duas Cidades, 1993, p 276.

${ }^{78}$ MIELIETINSKI, E. M. A poética do mito. Rio de Janeiro: Forense, 1987, p 54-55.
} 
poeta de "Louvação" - o boi agora unificado - despede-se da tarde de forma semelhante aos ranchos do Norte do Brasil que dão a despedida ao sair da lua, por meio de uma belíssima melodia - "Ao sair da Lua (bis)/ Meu boi vai-se embora! (bis)". ${ }^{79}$

José Miguel Wisnik nos lembra que as danças dramáticas são vistas por Mário de Andrade como "a conjugação do motivo da luta entre uma força principal e seu antagonista mais o princípio de morte e ressurreição" ${ }^{80}$. O estudioso aproxima esses elementos das danças dramáticas às etapas do mito da procura descritas por Northrop Frye em Anatomia da crítica.

O momento do agon [...] expõe o conflito, colocando o herói em confronto com seu antagonista; desse desencadear de forças contrárias resulta o páthos, a catástrofe ou a morte [...]. Segue-se um terceiro estágio, o sparagmòs, isto é, o dilaceramento, o desgarramento, o espedaçamento do corpo do herói, que pulveriza o sentido do universo, e ameaça a regressão do cosmos ao caos. [...] Luta e dilaceramento chegam assim, num quarto momento, à anagnórisis, o reconhecimento, a readmissão das partes num corpo inteiriço. ${ }^{81}$

Como afirma Wisnik, os quatro momentos do mito da procura estão espalhados pela obra de Mário de Andrade, pontuada por imagens de conflito ${ }^{82}$. Elementos do mito da busca aparecem, de forma marcante, no grupo de poemas Tempo da Maria, em que a estrutura das danças dramáticas é retomada. Em "Amar sem ser amado, ora pinhões!”, o contato com o "ventinho piricica", ao lado das sacudidelas do bonde - dança hipnótica -, possibilita a entrega mítica do poeta que, em sua multiplicação - morte simbólica -, retoma não apenas as tradições pagãs do culto ao vegetal, mas também atualiza a figura central de nossas danças dramáticas - o boi -, se identificando, ainda, com a morte e ressurreição do rei cristão, ápice, de acordo com Mário de Andrade, das noções místicas primitivas ${ }^{83}$ - "renovo o milagre cristão/ Com a minha multiplicação" ${ }^{84}$. Após a entrega sacrificial, por meio da qual o eu

\footnotetext{
${ }^{79}$ Dobrado de marcha tradicional do Boi-Bumbá de Belém no Norte do Brasil colhido por Mário de Andrade em Humaitá, no rio Madeira. (ANDRADE, M. Danças Dramáticas do Brasil. Edição organizada por Oneyda Alvarenga. Belo Horizonte: Itatiaia, 2002, p 691-2).

${ }^{80}$ WISNIK, J. M. Dança dramática. (Poesia/ música brasileira) Tese de doutoramento apresentada ao Departamento de Línguas Orientais e Teoria Literária. FFLCH - USP. São Paulo, 1979, p 72.

${ }^{81}$ Ibidem, p 72-3.

${ }^{82}$ Ibidem, p 73.

${ }^{83}$ ANDRADE, M. Danças Dramáticas do Brasil. Edição organizada por Oneyda Alvarenga. Belo Horizonte: Itatiaia, 2002, p 33.

${ }^{84}$ Versos do poema "Amar sem ser amado, ora pinhões!".
} 
lírico estabelece um contato profundo entre seu ser e a cultura popular, vivenciado por meio das cantigas e da embaixada do Tempo da Maria, o poeta-boi irá renascer transformado em "Louvação da tarde", pronto para estabelecer um outro tom para seus poemas, já apontado por Candido. O grupo de poemas de Remate de Males, portanto, é a representação dramática e musical - o rito - que, retomando a tradição popular que marcou os versos do Clã do jabuti, prepara a entrada na nova fase do poeta maduro dos anos trinta.

Wisnik aproxima, ainda, a sequiência do mito da procura, "em que um equilíbrio é tensionado e resolvido num novo equilíbrio", ao cerne da música tonal, a saber, a "cadência que intercambia os movimentos de tônica e dominante, pólos de tensão, para resolvê-los sobre a tônica". 85

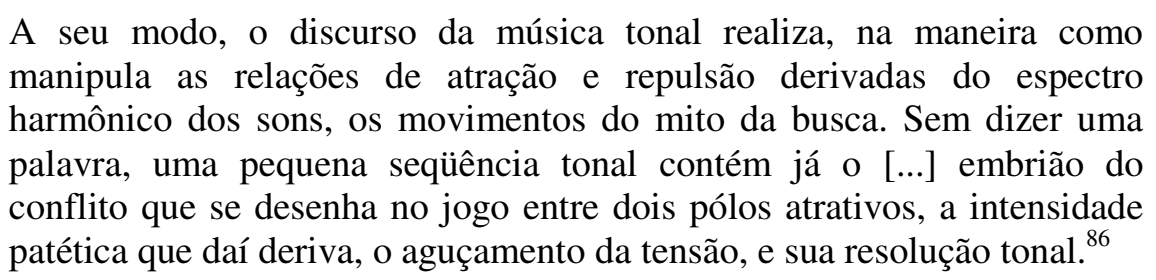

A cadência da música dos versos de Tempo da Maria, colocando em ação conflitos tonais, encena o mito da procura, cerne das danças dramáticas atualizadas por Mário de Andrade, por meio de seus versos. Em "Moda do corajoso", já aparece o embrião do conflito, a saber, a determinação em esquecer Maria e o desejo que invade o eu poético, pólos tonais que irão se digladiar, com uma intensidade imensa, em “Amar sem ser amado, ora pinhões!". No segundo poema de Tempo da Maria, momento de espedaçamento do eu poético, embates tonais sem resolução, assim como choques de ritmos diferentes, constroem a "experiência da simultaneidade" que, de acordo com Wisnik, irá marcar as obras musicais modernas ${ }^{87}$. Como lembra o estudioso, na história da música, "há uma linha de progressão que, gerada no romantismo pela intensificação do cromatismo ${ }^{88}$ no interior da totalidade, vai ao atonalismo, resultado anárquico da perturbação generalizada do sistema tonal” ${ }^{89}$. A música instável de “Amar sem ser amado, ora pinhões!” pode ser situada, nessa linha histórica, no Romantismo,

\footnotetext{
${ }^{85}$ WISNIK, J. M. Op. cit., p 73.

${ }^{86}$ Ibidem, p 73.

${ }^{87}$ WISNIK, J. M. O coro dos contrários: a música em torno da semana de 22. São Paulo: Duas Cidades, 1983, p 132.

${ }^{88} \mathrm{O}$ cromatismo "procede pela modulação contínua, leva as categorias tonais a mergulhar na ambigüidade - os eixos polarizadores vão diluindo-se cada vez mais, e dissolvendo-se sob a dinâmica da perpétua instabilidade" (WISNIK, J. M. O coro dos contrários: a música em torno da semana de 22. São Paulo: Duas Cidades, 1983, p 135).

${ }^{89}$ Ibidem, p 132.
} 
mas já indicando processos modernos. Em "Louvação da tarde”, após ter vivenciado, em "Amar", o aguçamento da tensão dos conflitos, o eu lírico deseja abandonar os embates por meio da entrega ao ritmo constante e calmo do forde. No penúltimo poema de Tempo da Maria, o eu lírico busca, por meio do esforço de organizar o próprio ritmo, atingir o quarto momento do mito da procura - "a volta triunfal dos fragmentos a uma totalidade renovada". 90 Dessa forma, Mário de Andrade não realiza apenas um resgate imitativo das danças dramáticas brasileiras, mas vivencia, em seus versos, "o êxtase e o conflito" 91 que as percorre.

O mito da busca, de acordo com Wisnik, presente em velhas narrativas, assim como no conflito tonal da música, nos surpreende ainda ao constituir a organização genital, na forma como Wilhelm Reich define o orgasmo: “tensão (mecânica), carga (elétrica), descarga (elétrica), relaxação (mecânica)" ${ }^{92}$.

Podemos ler o orgasmo através do mito da busca, e ele se torna carregado de história da espécie: ágon: tensão, páthos e sparagmòs correspondem à curva de excitação, ao colorido de carga e descarga de energias que essa busca comporta em si, e ao sentido de intensidade e desfazimento, de limite supremo e de morte que tradicionalmente se vê no processo orgástico, anagnórisis como reconhecimento, "refluir dos fluidos do corpo" (Reich), re-encontrado em sua totalidade com a energia que o move (Reich vê no orgasmo um processo de expansão do organismo que se opõe à angústia, vista como constrição e estreitamento $[\ldots]){ }^{93}$

Assim, ao incorporar a noção de morte e ressurreição - o mito da busca - das danças dramáticas aos poemas de Tempo da Maria, trabalhando os conflitos de forma musical como embates tonais, Mário de Andrade está realizando, no plano do ideal, a satisfação sexual - o orgasmo - interdita no plano real. O grupo de poemas é, portanto, o resultado da "vida dupla" do artista que, tímido, como nos lembra Mário de Andrade na Introdução à Estética Musical, realiza o amor por meio de idealizações ${ }^{94}$ - o orgasmo sublimado. O poeta aproveita, em versos, o caráter lúdico das danças dramáticas que permitem, como em um jogo, "exercitar

\footnotetext{
${ }^{90}$ WISNIK, J. M. Dança dramática. (Poesia/ música brasileira) Tese de doutoramento apresentada ao Departamento de Línguas Orientais e Teoria Literária. FFLCH - USP. São Paulo, 1979, p 73.

${ }^{91}$ Ibidem, p 65.

92 Ibidem, p 74.

93 Ibidem, p 74.

${ }^{94}$ ANDRADE, M. Introdução à estética musical. Pesquisa, estabelecimento de texto, introdução e notas por Flávia Camargo Toni. São Paulo: Hucitec, 1995, p 57-8.
} 
em brinquedo uma atividade vital [...] com o encanto a mais de disfarçar a aspereza consciente dessa atividade, seqüestrando-a e a transferindo para uma das suas imagens" 95 .

${ }^{95}$ ANDRADE, M. Danças dramáticas do Brasil. Edição organizada por Oneyda Alvarenga. Belo Horizonte: Itatiaia, 2002, p 71 (nota de roda-pé). 


\section{DANÇAS SENSUAIS}

No terceiro grupo de poemas de Remate de males (1930) - Poemas da negra (1929) , Mário de Andrade recupera formas populares, como havia feito em Clã do jabuti (1927) e em Tempo da Maria, que aparecem, no entanto, nos versos de 1929, absorvidas totalmente pelo eu lírico. Voltando-se para seu eu mais profundo e buscando realizar uma poesia introspectiva, prenúncio da produção madura dos anos 30, o poeta constrói versos que revelam sua intimidade marcada pelos ritmos, formas e sons populares próprios do Brasil.

A recuperação da forma popular, agora, é realizada por meio de versos lacônicos, "escritos em surdina, discretos e suaves" 1, como afirma Lafetá, traçados por um poeta elíptico que se insinua por meio de linhas reticenciosas.

Estou atingindo, Manu, acho que o cume da minha invisibilidade. E é nisso que estamos atualmente no máximo de separação: você todo sensibilidade, todo impulsivo, eu cada vez mais recatado, mais artífice, mais principalmente invisível. E me compreendo na minha invisibilidade [...]. Me parece que estou mais próximo de Rilke e um bocado de Ernst Toller [...]. Sobretudo de Rilke. Toller inda é visível por demais, eu quero palavras líricas, refletindo em antípodas discretos e quase sempre bem silenciosos os meus sentimentos e vida. Uma espécie de dupla verdade, as palavras criando, absolutamente castigadas pelo artista, um jogo vocabular com tudo o que um jogo vocabular pode dar de sugestão e boniteza pros outros. [...] Dessa orientação os "Poemas da negra" são o que de mais perfeito e legítimo fiz até agora. $^{2}$

De certa forma, o tom calmo e suave dos Poemas da negra nos remete à música lenta e grave dos catimbós, culto feiticista conhecido de perto por Mário de Andrade durante sua viagem ao Nordeste do país, em que, curioso para compreender a manifestação religiosa

\footnotetext{
${ }^{1}$ LAFETÁ, J.L. Mário de Andrade, o arlequim estudioso. In: A dimensão da noite. Organização de Antonio Arnoni Prado. São Paulo: Duas Cidades; Editora 34, 2004, p 223.

${ }^{2}$ Correspondência Mário de Andrade \& Manuel Bandeira. Organização, introdução e notas de Marcos Antonio de Moraes. São Paulo: EDUSP; IEB - USP, 2001, p 427-8.
} 
popular que unia influências européias, ameríndias e negras ${ }^{3}$, participou de sessão de "fechamento de corpo" realizada pelos catimbozeiros Mestre Manuel e Mestre João .

Em Música de feitiçaria no Brasil, Mário de Andrade descreve o estado de torpor que o tomou ao se deixar embalar pela música hipnótica entoada por Mestre João durante a sessão de catimbó.

O ritmo [do] refrão, a monotonia das cantigas molengas, o chique-chique suave do maracá, já principiavam a me embalar, a música me extasiava. Aos poucos meu corpo se aquecia numa entorpecedora musicalidade ao mesmo tempo que gradativamente me abandonavam as forças de reação intelectual. O próprio mestre João se amortecia aos poucos [...] [num] já quase estado de hipnose, o que se devia talvez em máxima parte, ao excesso de música entorpecente ${ }^{5}$.

A música calma dos Poemas da negra, além de retomar os silêncios e ausências de Rilke, como afirmou o poeta, recria, nos versos, o ambiente encantatório do catimbó, propício para o rito de fecundação e de comunhão com o sagrado, encenado pelos versos de 1929, em que o poeta procura deixar de lado, por um momento, as forças intelectuais e se entregar ao contato com as forças primitivas que encontrou expostas na religiosidade e na música do povo.

[No catimbó há] peças frequentemente lentas, onde no geral os compassos perdem a excessiva nitidez pelo arrastar grave do canto. Outras peças já são mesmo criadas em recitativos de ritmo livre e entoadas com tal liberdade de acentos e medidas de tempo, que é impossível lhes botar compasso. [...] O andamento lento da generalidade das peças de catimbó as distingue muito das nossas criações folclóricas profanas, que jamais quase são lentas. ${ }^{6}$

Além de nos remeter ao catimbó, os Poemas da negra retomam elementos das danças dramáticas populares, da mesma forma como os versos de Tempo da Maria (1926). No grupo de 1929, se dá a dissolução do eu lírico - sua morte simbólica - e posterior

\footnotetext{
${ }^{3}$ Como afirma Câmara Cascudo, "nome, organização, funcionamento, [no catimbó] tudo está escuro, misturado, confuso. É uma soma de influência e convergência [...]. A feição mais decisiva é da feitiçaria européia, o "mestre" e seu prestígio, a consulta sem obrigação de adesão. Ausência de iniciação, reuniões festivas, aprendizado ostensivo e sistemático. Os brasis deram sua flora, tuxauas cheios de mistérios, ensinando remédios ou indo flechar os inimigos, com flechas invisíveis que matam. O negro trouxe a parte mais triste e dolorosa. Seus 'mestres' foram todos catimbozeiros mortos, ex-escravos, vidas sem história, tornados soberanos nos reinos do Vajucá e do Juremal". (CASCUDO, L. C. Meleagro. Rio de Janeiro: Agir, 1951 apud RONCARI, L. $O$ Brasil de Rosa. São Paulo: Editora UNESP, 2004, p 118)

${ }^{4}$ Mário de Andrade descreve seu fechamento de corpo em $O$ turista aprendiz (ANDRADE, M. $O$ turista aprendiz. Estabelecimento de texto, introdução e notas de Telê Porto Ancona Lopez. Belo Horizonte: Itatiaia, 2002, p 223-227).

${ }^{5}$ ANDRADE, M. Música de feitiçaria no Brasil. Belo Horizonte: Ed Itatiaia; Brasília: INL, Fundação Nacional Pró-Memória, 1983 p 37.

${ }^{6}$ Ibidem, p 69.
} 
ressurreição, nos moldes dos bailados do povo, além de haver a representação de uma luta insinuada por meio do jogo sensual entre o poeta e a mulher, outro elemento das danças dramáticas. No entanto, nesse conjunto de poemas, não é utilizada, de forma explícita, a estrutura das danças populares, como é feito no grupo de 1926. Nos versos noturnos da negra, a forma do bailado aparece deglutida pelo eu lírico, moldando, como o fundo da poesia, a expressão do poeta múltiplo, formada, ainda, pela recuperação de outros elementos.

Em Tempo da Maria, o eu lírico vivencia, de forma sublimada, a noção de morte e ressurreição, própria de nossas danças, dramatizando o seqüestro do desejo pela dona branca, no momento vespertino, em que contrários se sobrepõem. Já nos Poemas da negra, não é mais cantado o amor impossível, mas sim o ato de sedução da mulher afro-descendente e a realização sexual, que ocorre à noite, momento de liberação da libido ${ }^{7}$. No grupo de 1929 , o poeta busca degustar a essência de seu país ao possuir o "ser primário" 8 da amada, vivenciando uma experiência ao mesmo tempo sensual e religiosa de comunhão com a mulher. Assim, tendo realizado o desejo de forma sublimada em Tempo da Maria, o poeta dos Poemas da negra busca viver a plenitude o encontro amoroso. Sob esse ponto de vista, os dois grupos são contrários e simetricamente complementares.

Os doze poemas curtos do grupo de 1929 mostram o jogo de sedução entre o eu poético e a negra - num crescendo, as tentativas iniciais de envolvimento sensual transformam-se, ao final, após a angústia que antecede o gozo, no prazer e na sensação de renascimento. O movimento de morte e ressurreição sexual invoca, também, as etapas do mito da busca que, como vimos, é similar à organização sexual - tensão, carga, descarga e relaxação - assim como aos embates tonais da música. Dessa forma, tanto a música como os mitos são colocados em cena, por meio do jogo de sedução.

A negra dos poemas de 1929 permite ao poeta entrar em contato com uma parte desconhecida dele mesmo - sua parte primitiva -, como se o eu lírico deslumbrasse, no corpo provocante da mulher, uma verdade anterior às verdades racionais. Os Poemas da negra, que podem ser lidos como um longo poema dividido em doze partes, contam a história da busca do poeta pelo primitivo que pulsa por meio da sensualidade da mulher desejada, enquanto nele se esconde. Ao mesmo tempo em que revelam essa busca, os poemas se constroem de

\footnotetext{
${ }^{7}$ Nos textos manuscritos sobre o seqüestro da dona ausente, Mário de Andrade mostra como, na época da colônia, a falta da mulher branca era sublimada em versos, enquanto os homens procuravam vencer os obstáculos do preconceito e da noção de pecado religioso, realizando o amor com a mulher negra. (ANDRADE, M. Seqüestro (manuscrito). In: CARVALHO, R. S. Edição genética d'O seqüestro da dona ausente de Mário de Andrade. Dissertação de Mestrado apresentada ao Departamento de Letras Clássicas e Vernáculas. FFLCH USP. São Paulo, 2001, p 42-4)

${ }^{8}$ Trecho de verso dos Poemas da negra.
} 
forma semelhante às estruturas míticas, identificadas, de acordo com Lévi-Strauss, à estrutura musical da fuga.

O antropólogo francês acredita que, no momento em que as narrativas míticas perdiam força, dando lugar ao saber científico e a novas formas de literatura, sua estrutura foi absorvida pela música ${ }^{9}$. De acordo com Wisnik, isso ocorreu no período do nascimento do tonalismo, "graças ao caráter discursivo e progressivo de que se investia a música tonal, capaz, agora, de sustentar, com recurso ao puro som, estruturas de cunho "narrativo"" ${ }^{10}$. Com o surgimento do sistema tonal, como nos lembra o estudioso, a música passa a se organizar de acordo com a estrutura mítica da crise e da reparação ${ }^{11}$. Segundo Wisnik, Claude Lévi-Strauss vê o mito como "uma narrativa em que a imbricação do sucessivo e do simultâneo dá ao sentido uma configuração cristalina e partitural, e a música (tonal) [como] uma estrutura sonora em que a trama discursiva dos elementos ganha um dimensionamento mítico" ${ }^{12}$, sendo os dois simétricos e complementares.

Acreditando que, ao moldar as formas musicais, a música redescobre estruturas mitológicas, o antropólogo francês destaca a forma da fuga como a recuperação mítica por excelência realizada pela música.

É, por exemplo, extraordinário que a fuga, como foi formalizada no tempo de Bach, seja a representação ao vivo do desenvolvimento de determinados mitos que têm duas espécies de personagens ou dois grupos de personagens. [...] A história inventariada pelo mito é a de um grupo que tenta escapar ou fugir do outro grupo de personagens. Trata-se então de uma perseguição de um grupo pelo outro, chegando às vezes o grupo A a alcançar o grupo B, distanciando-se novamente o grupo $\mathrm{B}$ - tudo como na fuga. Tem-se o que se chama em francês 'le sujet et la réponse'. A antítese ou antifonia continua pela história afora, até ambos os grupos estarem quase misturados e confundidos - um equivalente à stretta da fuga; finalmente, a solução ou clímax deste conflito surge pela conjugação dos dois princípios que se tinham oposto durante todo o mito. Pode ser um conflito entre os poderes de cima e os poderes de baixo, o céu e a terra, ou o sol e os poderes subterrâneos, e assim sucessivamente. A solução mítica de conjugação é muito semelhante em estrutura aos acordes que resolvem e põem fim à peça musical, porque também eles oferecem uma conjugação de extremos que se juntam por uma e última vez. ${ }^{13}$

O homem e a mulher que se seduzem mutuamente nos Poemas da negra são dois opostos que buscam se conjugar, como o céu e a terra das narrativas míticas. Assim, o poema

\footnotetext{
${ }^{9}$ LÉVI-STRAUSS, C. Mito e música. In: Mito e significado. Lisboa: Edições 70, 2000, p 68.

${ }^{10}$ WISINIK, J. M. O som e o sentido. São Paulo: Companhia das Letras, 2002, p 162.

${ }^{11}$ Ibidem, p 163.

12 Ibidem, p 164.

${ }^{13}$ LÉVI-STRAUSS, C. Op. cit., p 72-3.
} 
é, ao mesmo tempo, a retomada da fuga musical e do mito da perseguição, além de conter elementos das danças dramáticas e de ser, ainda, cantado no tom lamentoso do catimbó, como apontado acima, elementos eruditos e populares que se conjugam e se relacionam no íntimo do poeta, renascendo em forma de versos.

Como bem demonstra Wisnik, a forma com que Lévi-Strauss compreende os mitos é fugal, já que o "pensamento estrutural [do antropólogo] é tonal e polifônico." 14

Mas o "tonalismo" do pensamento de Lévi-Strauss não é do tipo dramático ou dialético (como o hegeliano, afinado com a sonata), e sim polifônico. Porque a fuga é o próprio modelo da razão estrutural: ela trabalha sobre oposições defasadas que procedem por variações imitativas sem desenvolvimento. [...] Como dois (ou mais) grupos (de "personagens") que se perseguem e se escapam, que se alcançam e se distanciam, as vozes se confundem e se diferenciam continuamente até se encontrarem, "por uma e última vez", no fim do percurso. [...] O que temos é movimento caleidoscópico em que os contrários ecoam entre si e se espelham até se revelarem como reverberações defasadas do mesmo. [...] No sistema tonal, todo mito busca resolver-se pela conjugação das forças em tensão, todo processo busca um termo final [...]. Na fuga, no entanto, [...] esse investimento erótico resolutivo e ambiguamente tanático [...] é alimentado pelo movimento incessante das vozes. A fuga foge da morte, sabendo que corre para ela. ${ }^{15}$ (grifos nossos)

O antropólogo que, quando criança, desejara ser músico, ao perceber sua incapacidade para tanto, concluiu que "se não era capaz de compor com os sons, talvez o pudesse fazer com os significados" 16 , transformando-se no "orquestrador de mitos", como lembra Wisnik, cuja obra "é, pois, auto-entendida como uma grande fuga" 17.

O pensamento de Mário de Andrade é estrutural como o de Lévi-Strauss, já que é polifônico e fugal. Sua obra poética se constrói também como uma grande fuga, em que vários pares de opostos se perseguem, formando espelhamentos em defasagem e simetrias múltiplas, sempre em busca de uma conjugação final, desejada e temida. Como no traje do poeta arlequinal, em que cada losango forma, um ao lado do outro, novos losangos, em uma expansão infinita, os poemas de Mário de Andrade, repletos, cada um, de espelhamentos, formam, um ao lado do outro, novas simetrias que são expandidas, depois, por meio de grupos de poemas que também, lado a lado, formam outros espelhamentos ${ }^{18}$.

\footnotetext{
${ }^{14}$ WISNIK, J. M. O som e o sentido. São Paulo: Companhia das Letras, 2002, p 167-8.

${ }^{15}$ Ibidem, p 167.

${ }^{16}$ LÉVI-STRAUSS, C. Op. cit., p 76.

${ }^{17}$ WISNIK, J. M. Op. cit., p 168-9.

${ }^{18}$ Maurício de Carvalho Teixeira, citando Haroldo de Campos, destaca o aspecto estrutural do pensamento de Mário de Andrade, habituado, de acordo com o que diz Gilda de Mello e Souza no prefácio de Introdução à
} 
Os Poemas da negra se constroem como uma fuga dentro da fuga maior formada pelo conjunto da obra poética de Mário de Andrade. As duas vozes em defasagem - o poeta e a negra - são dois opostos que percorrem os vários poemas do grupo em uma perseguição mútua, “"encarna[ndo]' o movimento desencontrado das identidades e das alteridades, que o mito resolve por conjugação extrema" ${ }^{\prime 19}$.

\section{Poemas da negra}

\section{I}

Não sei por que espírito antigo

Ficamos assim impossíveis...

A Lua chapeia os mangues

Donde sai um favor de silêncio

E de maré.

És uma sombra que apalpo

Que nem um cortejo de castas rainhas.

Meus olhos vadiam nas lágrimas.

Te vejo coberta de estrelas,

Coberta de estrelas,

Meu amor!

Tua calma agrava o silêncio dos mangues.

No poema, há uma identificação entre a negra e a natureza. Da mesma forma como o mangue se projeta no ambiente por meio de um "favor de silêncio/ e de maré" - ambiente singular e simbólico repleto de fecundidade e de escuridão misteriosa, tocado na superfície pela luz da Lua e fecundado ciclicamente pelo mar -, a negra, como se também influenciada pelo satélite controlador das marés e dos ciclos de fecundidade femininos, envolve o poeta com uma sensualidade forte e silenciosa, levando-o às lágrimas ao admirá-la (ao mangue) coberta de estrelas $^{20}$. A mulher começa a despertar no amante o desejo sexual ao se mostrar, assim como o terreno úmido e fértil, pronta a ser fecundada, tanto pelo mar, pela luz da Lua, pelas estrelas, como pelo homem paulista marcado pela tradição européia. Ao desejar a negra,

Estética Musical (1995, p XVI), “a pensar as várias manifestações artísticas de acordo com a ordenada sistematização musical” (TEIXEIRA, 2007, p 13).

${ }^{19}$ Ibidem, p 167.

${ }^{20}$ A mulher coberta de estrelas e identificada com a natureza é similar à “Aurora Mulher” de Cícero Dias. Anexo A (Cícero Dias: oito décadas de pintura. Projeto, curadoria e coordenação de Waldir Simões de Assis Filho. Curitiba: Museu Oscar Niemeyer, 2006, p 87). 
o eu lírico quer provar o mangue primário, "antigo e movediço" ${ }^{21}$, como diz o verso do poeta Fabrício Corsaletti, espaço que representa, ao mesmo tempo, a perenidade e a mudança constante (cíclica) da natureza, tocado, ainda, pela Lua, "o astro dos ritmos da vida", como diz Eliade, ao lembrar o eterno retorno às formas inicias realizado pelo satélite, símbolo de morte e ressurreição ${ }^{22}$.

A comoção do poeta frente à amada transparece por meio da disposição dos últimos versos da segunda estrofe que, num crescendo, vão ganhando intensidade, ressaltada pela repetição - "coberta de estrelas" -, assim como pelo ponto de exclamação. Essa tensão da comoção contrasta com o verso sentencioso final que, por meio da solenidade do decassílabo, anuncia a gravidade e a calma da negra que "agravam" - tornam mais grave e mais pesado - o silêncio do mangue. Sob os versos, a gravidade da negra é lembrança constante, parecida com o som da percussão das danças dramáticas, principalmente dos congos de origem africana, estabelecendo-se, ainda, quase como que a "tônica fixa, que permanece como um fundo imóvel, explícito ou implícito, sob a dança das melodias" da música modal - monótona, sedutora e envolvente ${ }^{23}$.

Os versos dos Poemas da negra refletem o silêncio e a solenidade da amada e do mangue e, num andamento lento - grave -, desvelam a sensação do poeta frente à mulhersombra que, ao mesmo tempo, pode e não pode ser tocada. A ausência da negra nos faz lembrar a sensação de apartamento presente nos poemas de Rilke, em que a mão espalmada do eu lírico sente ainda o "ausente peso" da estrela ${ }^{24}$. A sensação do poeta que apalpa sombras - "És uma sombra que apalpo/ Que nem um cortejo de castas rainhas" - percorre os versos que, por meio de sentenças lacônicas, passam ao leitor a mesma impressão de conseguir e não conseguir apreender algo que se esconde por meio do silêncio e da gravidade das linhas poéticas. Como um artifício criado pelo poeta para colocar em cena os embates

\footnotetext{
21 "sou antigo e/ movediço/ como o mangue" (CORSALETTI, F. "Movediço". In: Estudos para seu corpo. São Paulo: Companhia das Letras, 2007).

${ }^{22}$ ELIADE, M. Tratado de história das religiões. São Paulo: Martins Fontes, 1998, p 16.

23 WISNIK, J. M. O som e o sentido. São Paulo: Companhia das Letras, 2002, p 78.

24 "Palma, suave cama amarrotada onde estrelas dormindo tinham deixado vincos ao subirem para o céu.

$[\ldots]$

$\mathrm{Ai}$, as duas camas de minhas mãos, abandonadas e frias, leves de um ausente peso desses astros de bronze."
}

RILKE, R. M. Jardins. Tradução de Fernando Santoro. Rio de Janeiro: Sette Letras, 1995, p 27. 
entre o mundo primário do povo e o mundo erudito do eu lírico, a negra é a presença de uma ausência que, por meio do silêncio de quem não tem voz, causa desconforto no poeta e no leitor, insinuando-se como algo que não pode ser totalmente possuído. Mais do que uma mulher, a negra é uma projeção do desejo do poeta.

A negra, como "castas rainhas" que não podem ser tocadas, apesar de despertar o desejo do poeta, não se entrega ainda ao amante nos primeiros poemas do grupo, dando início, assim, ao jogo de sedução. O cortejo de rainhas que não se deixam apalpar nos faz lembrar dos Congos, danças dramáticas de origem africana estudadas por Mário de Andrade, e, em especial, de algumas peças descritas por Sylvio Romero e citadas pelo modernista, já que nelas a "única ação dramática residia no cordão defender três rainhas que lhe iam no centro, contra dois ou três indivíduos destacados especialmente para derrubar as coroas delas" ${ }^{25}$. A brincadeira, descrita por Mário de Andrade como tentativa de destruição do poder, simbolizado pela coroa ${ }^{26}$, devia encerrar muita sensualidade, já que o jogo de investidas e recuos encenado pelas rainhas e pelos homens que as atacavam, é similar ao jogo de sedução sexual.

\section{II}

Não sei si estou vivo...

Estou morto.

Um vento morno que sou eu

Faz auras pernambucanas.

Rola rola sob as nuvens

$\mathrm{O}$ aroma das mangas.

Se escutam grilos,

Cricrido contínuo

Saindo dos vidros.

Eu me inundo de vossas riquezas!

Não sou mais eu!

Que indiferença enorme...

Se, em Tempo da Maria, o eu lírico se dispersa pela cidade após ter sido tocado pelo ventinho piricica, nos Poemas da negra, o vento morno nordestino - pleno e fecundo - não apenas toca, mas é o poeta que, numa identificação profunda com o seu país, faz auras brisas e aragens - pernambucanas. Assim como aconteceu em Tempo da Maria, o vento dos poemas de 1929 indica a dissolução e morte do poeta-boi - "Não sei se estou vivo... / Estou

\footnotetext{
${ }^{25}$ ANDRADE, M. Danças Dramáticas do Brasil. Edição organizada por Oneyda Alvarenga. Belo Horizonte: Itatiaia, 2002, p 465.

${ }^{26}$ Ibidem, p 378.
} 
morto". O verso de "Amar sem ser amado, ora pinhões!" em que o eu lírico anuncia sua dispersão pela paisagem - "Não sou eu, sou eus em farrancho" - é retomado nos Poemas da negra, em que o vento-poeta afirma ter se dispersado - "Não sou mais eu!". Fazendo rolar o odor forte das mangas sob as nuvens, realçado pelo calor tropical, acompanhado pelo cricri monótono e vítreo dos grilos, o poeta sente-se parte de seu país, ao poder conferir mais de perto nossas riquezas procuradas avidamente pelo modernista que, em São Paulo, sentira-se longe do sabor e do cheiro das partes longínquas do Brasil, apesar de cercado por um "despotismo de livros" 27.

Os Poemas da negra foram escritos em 1929, ano em que Mário de Andrade realizou sua viagem etnográfica ao Nordeste ${ }^{28}$. Em suas andanças, imbuído da vontade de conhecer a fundo seu país, o pesquisador aplicado colheu material sobre "danças dramáticas, sobre melodias do Boi, sobre música de feitiçaria, religiosidade popular, crenças e superstições [e] poesia popular" ${ }^{29}$, pesquisa que marcou os versos da negra, dedicados, inclusive, ao artista plástico pernambucano Cícero Dias, com quem o poeta esteve em sua viagem.

Em um dos textos escritos durante a estadia na região Nordeste, compilados depois, por Telê Ancona Lopez, em O turista aprendiz, o viajante se mostra em plena sintonia com a paisagem nordestina, tomado e transformado pelo vento, assim como acontece nos Poemas da negra - "Eh! ventos, ventos de Natal, me atravessando como se eu fosse um véu. Sou véu. Não atravanco a paisagem, não tenho obrigação de ver coisas exóticas... Estou vivendo a vida de meu país..." ${ }^{30}$. Em "Carnaval carioca" (Clã do jabuti - 1927), antes de se entregar aos prazeres e às sensações da festa do povo, o poeta sentia sua "frieza de paulista" repleta de "policiamentos interiores" como a marca da cultura européia em seu traje de losango. Em sua viagem de turista aprendiz, no entanto, o modernista procura se despir do olhar europeu distanciado, tentando, por meio de uma entrega maior, conhecer a si mesmo por meio do outro.

Após declarar sua própria dispersão - a morte simbólica -, o poeta arremata o segundo poema do grupo de 1929 com a retomada de um dos versos de "Dois poemas acreanos", de

${ }^{27}$ Cf. o poema "Dois poemas acreanos": "Seringueiro, eu não sei nada!/ E no entanto estou rodeado/ Dum despotismo de livros, / [...] Me sinto bem solitário/ No mutirão da sabença/ Da minha casa, amolado/ Por tantos livros geniais,/ [...] E não sinto os meus patrícios!/ [...] E não sinto os seringueiros/ Que amo de amor infeliz!...” ANDRADE, M. Poesias completas. Edição crítica de Diléa Zanotto Manfio. Belo Horizonte: Villa Rica, 1993, p 205.

${ }^{28}$ Iniciada em dezembro de 1928 e finalizada em fevereiro de 1929.

${ }^{29}$ LOPEZ, T. A. "Viagens etnográficas" de Mário de Andrade. In: ANDRADE, M. O turista aprendiz. Estabelecimento de texto, introdução e notas de Telê Ancona Lopez. Belo Horizonte: Itatiaia, 2002, p 21.

${ }^{30}$ ANDRADE, M. O turista aprendiz. Estabelecimento de texto, introdução e notas de Telê Ancona Lopez. Belo Horizonte: Itatiaia, 2002, p 207. 
Clã do jabuti - "Que indiferença enorme...". A "indiferença” do seringueiro, desejada ao longe pelo poeta paulista do livro de 1927 e sentida de forma mais viva por ele, nos Poemas da negra, foi descrita em $O$ turista aprendiz.

Outro caso concludente de maleita nirvanizante. [...] Lá vinha bem no centro do igarapé uma lancha grande [...]. Na proa, [...] vem um rapaz [...] As moças fazem barulho, se desejando desejadas, as perversas. O rapaz nem olha. Pula a bordo, passa por nós sem olhar [...] Quando desce, passa pelo outro lado do navio, evitando a nossa vista. [...] E a lancha vai, nos dando as costas para todo o sempre. Sem um olhar! Não se trata de um problema de feli-ou infelicidade... [...] Possivelmente se tratará de uma substituição de problemas, uma diluição de problemas dentro da indiferença. Ou dentro da paciência. Ou dentro da monotonia [...] A imagem do moço me persegue. Ter uma maleita assim, que me deixasse indiferente... ${ }^{31}$ (grifos nossos)

Em carta a Manuel Bandeira, escrita em 11 de maio de 1929, Mário afirma sentir-se no mesmo estado "nirvanizante" do seringueiro com maleita, descrevendo-se propenso a se libertar dos problemas da vida intelectual por meio do isolamento, procurando aquele "ponto platônico de sabedoria, escusez, em que as almas não sabem mais ficar nem tristes nem alegres, o limbo calmo que Dante entreviu..." - a "indiferença" 32 .

O tema da indiferença percorre a obra de Mário de Andrade, marcando Macunaíma, que a exerce por meio da preguiça, assim como vários poemas, como o "Rito do irmão pequeno" (1931), em que o poeta conclama o mais jovem a "exercer a preguiça, com vagar". Telê Ancona Lopez nos lembra da forma amorosa com que Mário constatou a "lógica diferente, sensível e poética" de nosso povo, ao ser seduzido pelo "ritmo de contemplação" da Amazônia "que adivinha pronto para dialogar com a valorização do ócio criador dos poetas clássicos e a captação sem pressa da vida, conforme Lao-tse" 33.

Mário de Andrade, no texto “A poesia em 1930”, fala da obra do artista plástico Cícero Dias, mostrando como é marcada pela "indiferença", apontando, na arte dele, a “impulsão macuimática do indivíduo" que atinge o estado de não ser nem triste nem alegre, de acordo com Platão ${ }^{34}$. Em um texto crítico sobre o amigo pernambucano, escrito em 1944 a pedido do diretor da revista Arquivos, de Recife, Mário destaca o profundo lirismo do desenhista, além da grande fatalidade de expressão de Cícero Dias, que nos deixa com a

\footnotetext{
${ }^{31}$ Ibidem, p 142.

${ }^{32}$ Correspondência Mário de Andrade \& Manuel Bandeira. Organização, introdução e notas de Marcos Antonio de Moraes. São Paulo: EDUSP; IEB - USP, 2001, p 417 (Para exemplificar o estado platônico desejado, Mário transcreve o segundo poema da negra, na mesma carta).

${ }^{33}$ LOPEZ, T. P. A. Mariodeandradeando. São Paulo: Hucitec, 1996, p 96-7.

${ }^{34}$ ANDRADE, M. Aspectos da Literatura Brasileira. Belo Horizonte: Itatiaia, 2002a, p 55.
} 
sensação de um "determinismo, duma predestinação angélica fatal”, ao observarmos suas aquarelas que exigem "uma total passividade crítica e uma atividade psicológica quase feroz de tamanha [...], uma sensibilidade receptiva enorme", já que seus elementos "são. São apenas em relação a eles mesmos; são apenas o que são; são apenas porque existem" e "nos sacodem com violência irresistível" 35 .

Mário de Andrade deseja apreender, nos Poemas da negra, o que viu exposto nas aquarelas de Cícero Dias e depois sentido quando esteve no Norte e Nordeste do país: a singularidade dos objetos sem alma de que fala em crônica do Turista Aprendiz.

Mas já estamos vivendo melhor esta vida equatorial. Não tem dúvida que ela é mais objetiva que a nossa vida no sul. Não é uma questão de maior ou menor espiritualidade nossa, mas espiritualidade das coisas. Não sei, mas uma paisagem dos arredores de São Paulo, uma cidadinha, um rio [...] sinto quando os contemplo, que há qualquer coisa neles que eu não compreendo, uma como vida interior deles [...] Isso: a alma das coisas. Desde as dunas no Nordeste a alma das coisas desapareceu. Tudo aparece revestido de uma epiderme violenta, perfeitamente delimitada, que não guarda mistérios. Mais franqueza, uma certa brutalidade leal de "coisa" mesmo. E disso vem uma sensualidade de contato em que a gente se contagia de uma violenta vida sensual, embriaga. ${ }^{36}$ (grifos nossos)

A negra dos poemas de Mário de Andrade é desenhada, assim como os elementos das aquarelas de Cícero Dias, como "uma revelação instantânea e imutável” ${ }^{37}$ das coisas sem alma vistas pelo poeta. O ímpeto amoroso de quem quer possuir um ser que "é apenas porque existe" - franco e objetivo - nos é mostrado, paradoxalmente, por meio de um grupo de poemas marcado de forma profunda pelo lirismo subjetivo do poeta e por versos sentenciosos e lacônicos, como se estivéssemos contemplando a reverberação dessas "Coisas" no ser mais íntimo do eu lírico e escutando-a, por meio de seus versos. O grupo de poemas é feito, aliás, por meio de uma sobreposição singular de opostos: versos de um poeta invisível que revela em forma de silêncios seus "sentimentos e vida" - sua subjetividade -, como Mário disse em carta a Manuel Bandeira, e que deseja, nessas mesmas linhas, o seu oposto - a objetividade da negra. Podemos pensar, com isso, que o grupo mostra um poeta que busca resgatar, como Cícero Dias, os universais dentro dele próprio.

\footnotetext{
${ }^{35}$ ANDRADE, M. Cícero Dias e as danças do nordeste. In: Teresa: revista de Literatura Brasileira/ área de Literatura Brasileira. Departamento de Letras Clássicas e Vernáculas. FFLCH. USP - n. 1 (1ºm. 2000). São Paulo: ed 34, 2000, p 50-2.

${ }^{36}$ ANDRADE, M. O turista aprendiz. Estabelecimento de texto, introdução e notas de Telê Ancona Lopez. Belo Horizonte: Itatiaia, 2002, p 163.

${ }^{37}$ ANDRADE, M. Cícero Dias e as danças do nordeste. In: Op. cit., p 54.
} 
Em Cícero Dias as formas assumem valores de universal, em sínteses tão abstratas que nele um cachorro se confunde com um burro, é o Quadrúpede, a pomba se confunde com o urubu, é a Ave [...] sem particularização individualista, os seus assuntos são primários e genéricos, a sexualidade (se confundindo com o amor), o assunto da morte, o do prazer, o do Além ${ }^{38}$.

Após a dispersão inicial, o poeta se entrega aos prazeres provindos dos primeiros contatos com a negra, mulher que o atrai por lembrar o caráter imediato dos objetos sem alma do Nordeste.

III

Você é tão suave,

Vossos lábios suaves

Vagam no meu rosto,

Fecham meu olhar.

Sol-posto.

É a escureza suave

Que vem de você,

Que se dissolve em mim.

Que sono...

Eu imaginava

Duros vossos lábios,

Mas você me ensina

A volta ao bem.

IV

Estou com medo...

Teu beijo é tão beijo,

Tua inocência é dura,

Feita de camélias.

Oh, meu amor,

Nós não somos iguais!

Tu me proíbes

Beber água após...

Eu volto à calma

E não te vejo mais.

No terceiro poema, a negra é retratada como dona de lábios suaves que vagam, como ondas na areia, sobre o rosto do poeta, dando-lhe um prazer brando e delicado de quem se entrega, com calma e confiança, à escureza suave da mulher-noite que se dissolve nele,

\footnotetext{
${ }^{38}$ ANDRADE, M. Aspectos da Literatura Brasileira. Belo Horizonte: Itatiaia, 2002a, p 55-6.
} 
também ela vivenciando, assim, por meio de sua dissolução, o rito de morte e ressurreição instaurado por meio do desejo sexual. Dessa maneira, o poeta sente, em seu ser, a verdade fatal entrevista, antes, nas coisas sem alma do Nordeste, levada até ele pela negra que, diferente do que pensara, não possui lábios duros, assim imaginados em uma mulher fortemente ligada à verdade primária da natureza e identificada com a objetividade das coisas do Nordeste. O poeta assume a posição passível de quem se deixa seduzir e penetrar pela contundência da vida nordestina - "se dissolve em mim" - trazida a ele, paradoxalmente, por lábios suaves e por movimentos calmos da mulher que lhe ensina "a volta ao bem".

Os versos são marcados por sussurros de sibilantes e por aliterações que fazem com que o poeta adormeça, além de realçar o clima sensual que envolve os amantes - "Você é tão suave, / Vossos lábios suaves/ Vagam no meu rosto, / Fecham meu olhar”. Uma estrofe incisiva formada por um só verso - "Sol-posto" - fecha o primeiro período, finalizando a cadência. No entanto, outra estrofe curta - "Que sono..." -, de forma diferente, deixa em aberto a sensação de entrega confiante à mulher, funcionando, ambas, como pausas em meio aos versos, reforçando o ritmo lento que os percorre.

No quarto poema, no entanto, o eu lírico anuncia seu medo frente à mulher que tem não lábios delicados, mas um "beijo tão beijo", plenamente identificado com a verdade fatal dos objetos sem alma do Nordeste. No entanto, essa mulher forte e incisiva, tratada não mais pelo carinhoso "você", e sim pelo contundente "tu", em versos que abandonam a insistência das sibilantes, tem uma inocência que, apesar de "dura", é formada por delicadas camélias, flores que não podem ser tocadas, já que isso macularia sua brancura com manchas marrons, símbolo, portanto, da pureza virginal. Dessa forma, a mulher pura que procura não ceder aos apelos do homem ativo e sensual, paradoxalmente, é retratada como forte e temível, levando o poeta, não à calma, como no terceiro poema, mas à exacerbação dos desejos que precisam ser controlados, depois, pelo eu lírico - "Eu volto à calma/ E não te vejo mais."

O segundo e o terceiro poemas revelam uma mulher contraditória. A negra é descrita, inicialmente, como uma amante suave e desejosa, que se entrega à sensualidade e à própria dissolução - morte - no ser do poeta. No entanto, no quarto poema, a mesma mulher revela uma impetuosidade que amedronta o amante, ao lado de uma castidade impensada - "Tu me proíbes/ Beber água após...”. Por meio do jogo sensual de entregas e recusas, a negra provoca a tensão sexual que prepara e antecede o gozo, levando o poeta a experimentar sensações díspares: é possuído, mas, ao desejar possuir, é proibido. Dessa forma, os dois amantes vão desenhando os compassos da fuga musical que formam os Poemas da negra, por meio de 
perseguições e proibições, se alcançando e se distanciando num movimento sensual incessante.

\section{V}

Lá longe no sul,

Lá nos pés da Argentina,

Marulham temíveis os mares gelados,

Não posso fazer mesmo um gesto!

Tu me adivinhas, meu amor,

Porém não queres ser escrava!

Flores!

Apaixonadamente meus braços desgalham-se,

Flores!

Flores amarelas do pau-darco secular!

Eu me desgalho sobre teu corpo manso,

As flores estão caindo sobre teu corpo manso,

Te cobrirei de flores amarelas!

Apaixonadamente

Eu me defenderei!

Os primeiros versos do quinto poema nos remetem à contraposição estabelecida no ser do poeta, entregue aos ventos mornos nordestinos, mas ainda marcado pela lembrança de sua frieza de paulista, invocando-a em meio ao clima quente do Norte, como um dos elementos de seu desejo sexual que, impetuoso - como mares gelados -, se agita ameaçador, ao desejar o seu oposto, a saber, a mulher tropical dona de um "corpo manso".

A mulher negra, no entanto, recusa tornar-se escrava do amante, evitando, assim, reassumir a posição de dominada frente ao homem dominador, o que a faria retomar a carga histórica da escravatura, vivida por seus antepassados e discutida em poemas como "Nega Fulô", de Jorge de Lima.

Frente à recusa da amada que "não quer ser escrava" apesar dos desejos do poeta, o eu lírico, após ter sido disperso pelo vento - e como vento -, é, agora, numa identificação com as coisas sem alma do nordeste, o "pau-darco secular", ipê amarelo constantemente divisado na paisagem brasileira. Por meio da imagem dos braços que se desgalham sobre a amada, o poeta - representado pela imagem fálica do "pau-darco" -, multiplicando-se em flores, fecunda a terra-mulher. Se no segundo poema, a escureza da negra se dissolve no poeta, agora, a mulher passiva recebe a cor clara que a acaricia de forma suave por meio do toque um pouco gelado como o poeta paulista -, mas gentil das pétalas amarelas. 
O enlace amoroso das flores e da negra lembra a história da moça Naipi transformada em cascata pela cobra Capei, em punição à sua traição, em um dos episódios de Macunaíma. Donzela escolhida pela boiúna para servi-la, Naipi entrega-se, antes, ao guerreiro Titçatê que havia chorado copiosamente sob flores amarelas de ipê que caiam sobre seus ombros, ao saber da escolha de Capei - "Sempre no tempo em que os ipês de beira-rio se amarelavam de flores a boiúna vinha na taba escolher a cunhã virgem que ia dormir com ela" ${ }^{39}$. As flores de ipê são levadas à rede de Naipi pelo guerreiro que, após ter sido mordido pela amada impetuosa, que assim procedia para defender sua castidade, enche a boca da moça com elas, evitando, dessa forma, sua fúria. A virgem e seu "vencedor" brincam, então, "feito doidos entre sangue escorrendo e florzinhas de ipê" ${ }^{40}$. A voluptuosidade da indígena e seu beijo mortal que faz o amante "geme(r) de raiva amando" ${ }^{41}$ lembram o beijo forte da negra que faz temer o poeta que procura, como o guerreiro Titçatê, se defender, "apaixonadamente", com flores amarelas. A impetuosidade e a suavidade da negra - seu corpo manso parecido com o corpo "mais molengo que embiroçú" 42 de Naipi - são desejadas pelo poeta como quem quer, ao mesmo tempo, a volúpia carnal e a suavidade do corpo virginal. Se em Tempo da Maria, a mulher proibida é desejada ao longe pelo poeta, em Poemas da negra, o eu lírico não titubeia frente à moça virgem que o proíbe de "beber água após...”.

A mulher recoberta por pétalas, além de nos remeter a Macunaíma, nos faz lembrar também das aquarelas de Cícero Dias, da década de 1920, em que mulheres gigantescas aparecem em posições sensuais envolvidas por flores que as tocam como se as quisessem fecundar ${ }^{43}$.

O quinto poema, extremamente pictórico, arranja suas imagens de tal forma que, ao lêlo, somos tomados por um estranhamento surpreso similar às sensações que brotam ao observarmos as aquarelas de Cícero Dias. Como nelas, as imagens do poema - a lembrança dos mares argentinos, invocada em plena paisagem nordestina, e o ipê amarelo compondo, ao lado da figura da mulher, coberta de flores, o quadro - se sobrepõem e apenas são, invocando o mesmo ambiente de sonho das telas do artista plástico pernambucano.

\footnotetext{
${ }^{39}$ ANDRADE, M. Macunaíma. Belo Horizonte; Rio de Janeiro: Livraria Garnier, 2000, p 32.

${ }^{40}$ Ibidem, p 33.

${ }^{41}$ Ibidem, p 33.

42 Ibidem, p 32.

${ }^{43}$ Anexo B (Cícero Dias: oito décadas de pintura. Projeto, curadoria e coordenação de Waldir Simões de Assis Filho. Curitiba: Museu Oscar Niemeyer, 2006, p 19).
} 
De certa forma, os Poemas da negra exigem do leitor um desarmamento crítico e um trabalho psicológico intenso, uma sensibilidade receptiva "desarvorada, sem nenhuma escravização intelectual, assombrável e assombrada", similar aos apontados por Mário como necessários para a compreensão das obras de Cícero Dias. "E então essas aguarelas [esses poemas] nos aproximam duma alma... que não é deste mundo; e a gente se purifica [...] ao seu convívio" ${ }^{44}$.

\section{VI}

Quando

Minha mão se alastra

Em vosso grande corpo,

Você estremece um pouco.

É como o negrume da noite

Quando a estrela Vênus

Vence o véu da tarde

E brilha enfim.

Nossos corpos são finos,

São muito compridos...

Minha mão relumeia

Cada vez mais sobre você.

E nós partimos adorados

Nos turbilhões da estrela Vênus!...

Defendido por flores amarelas, o poeta é, como o guerreiro Titçatê, o vencedor da virgem e, portanto, o detentor do direito de tocar "seu grande corpo" ${ }^{45}$ com a mão que se alastra sensualmente como a luz da estrela Vênus, causando sensações de prazer na noitemulher que estremece "um pouco". O pequeno tremor deixa entrever o apetite lascivo que percorre o corpo desejante, mas que ainda resiste da mulher, refém da volúpia vinda da entrega à mão "estrangeira” que a invade. A posição dúbia e instigante da negra que, ao mesmo tempo, resiste e deseja, arrebata o poeta que, como estrela, quer possui a noite, se entregando à morte simbólica, por meio do próprio alastramento, mas deixando-se também envolver pelo "negrume", em uma fecundação mútua.

Após o amor crepuscular de Tempo da Maria, em que desejos e proibições marcaram os versos do poeta ao cantar a dona ausente, resolvendo seus dilemas ao afastar o céu e a terra, a fim de poder sublimar os impulsos sexuais por meio da poesia, em Poemas da negra,

\footnotetext{
${ }^{44}$ ANDRADE, M. Cícero Dias e as danças do nordeste. In: Op. cit., p 52.

${ }^{45}$ Corpo grande como o das mulheres das aquarelas de Cícero Dias.
} 
a luz libidinosa e dionisíaca de Vênus vence "o véu da tarde" que impedira a realização física do amor nos poemas de 1926, anunciando, agora, o momento de sentir, apalpar e de se impregnar da sofreguidão sensual que nasce por meio do contato com a negra - a terra-mãe, a noite-mulher. O poeta se permite, portanto, o abandono sem medos e sem escrúpulos ao turbilhão de desejos que o arrebata.

No grupo de poemas de 1929, a negra se apresenta fortemente identificada com a natureza nordestina que a cerca, sendo apontada, alternadamente, como a terra e como a noite, ambos donos de uma escuridão profunda e misteriosa. No primeiro poema, a amada é descrita coberta de estrelas - como o mangue que as reflete ou como a noite que as detém -, sendo, depois, apontada como "sol-posto" - a noite escura que invade o poeta -, aparecendo, ainda, no quinto poema, como a terra envolta por flores que caem do ipê e, finalmente, no sexto texto, é a noite negra que estremece ao surgir da estrela da tarde. Dessa forma, os versos de Poema da negra retomam os pares opostos "Céu e Terra" que, em "Amar sem ser amado, ora pinhões!", no momento de intensificação de anseios amorosos, aparecem enlaçados - "O céu se encurva sobre o chão/ Num gesto forte de abraçar" -, e, em "Louvação da tarde", são afastados pelo crepúsculo para darem lugar aos devaneios por meio dos quais o poeta se livra do inútil excessivo dos sonhos - "Pois afastando o céu de junto à Terra, / Tarde incomensurável, me permites, / [...] lançar bem alto nos espaços essa/ mentirada gentil do que me falta". No entanto, aqui, o Céu e a Terra aparecem ligados no próprio ser da negra, representante da noite e do mangue, despertando, portanto, o desejo do poeta que almeja possuir a totalidade por meio dela, rematando a fragmentação moderna numa totalização mito-poética, já que o mito, como afirma Bosi, “concilia as contradições que não lhe é dado pensar" ${ }^{46}$.

"Terra (Gaia), primeiro, deu à luz um ser igual a ela mesma, capaz de a cobrir totalmente, o Céu (Uranos) estrelado [...]" [citação da Teogonia, de Hesíodo]. Este par primordial deu origem à família numerosa dos deuses [...]. O casamento do Céu e da Terra é a primeira hierogamia. Os deuses tratarão de repeti-la e os homens, por seu turno, imitá-la-ão com a mesma gravidade sagrada com que imitavam qualquer gesto realizado na aurora dos tempos. ${ }^{47}$

\footnotetext{
46 “'Oswald, Mário, Alcântara Machado, os paulistas por excelência do movimento, [...] enxergavam o Brasil como um mito enorme, protéico, de que seriam símbolos seminais os totens amazônicos [...]. O ângulo de visão era o de intelectuais [...] que se propunham desentranhar a poesia das origens, o substrato selvagem de uma 'raça'; e que desejavam intuir o modo de ser brasileiro aquém da civilização" (BOSI, A. Moderno e modernista na Literatura Brasileira. In: Céu, inferno. São Paulo: Duas Cidades; Ed. 34, 2003, p 216-7.)

${ }^{47}$ ELIADE, M. Tratado de história das religiões. São Paulo: Martins Fontes, 1998, p 193.
} 
Nos Poemas da negra, é atualizada a hierogamia inicial, citada por Hesíodo, tema da mitologia universal que aparece em diferentes civilizações, como entre os negros Ioruba, em que estão presente os pares opostos Olórun e Oduna ("a negra”) ${ }^{48}$. No entanto, o poeta revive a união sagrada de forma diferente, já que ele não é um dos pares da união primordial - o céu ou a terra -, mas aquele que deseja possuir a conjugação dos opostos - a negra - que se impõe como contrário ao seu ser fragmentado ${ }^{49}$. O desejo de união sexual reveste-se, portanto, de um caráter sagrado e o ato de sedução se configura como uma vivência religiosa.

De acordo com Eliade,

Para aqueles que têm uma experiência religiosa, toda a Natureza é suscetível de revelar-se como sacralidade cósmica [...]. O homem das sociedades arcaicas tem a tendência para viver o mais possível no sagrado [...]. Essa tendência é compreensível, pois para os "primitivos", [...] o sagrado equivale [...], em última análise, à realidade por excelência. O sagrado está saturado de ser. [...] É, portanto, fácil de compreender que o homem religioso deseje profundamente $s e r$, participar da realidade. ${ }^{50}$

O poeta busca a realidade primeira de que fala Eliade, ao querer sentir no próprio ser os objetos e a paisagem do Nordeste, assim como por meio do movimento de sedução da negra, representante da natureza que revela o sagrado. Como o homem "primitivo", para o qual a sexualidade não é apenas um ato fisiológico, mas "é, ou pode tornar-se, um 'sacramento', quer dizer, uma comunhão com o sagrado" ${ }^{51}$, o eu lírico realiza as etapas da sedução como quem vivencia o mito da busca, em um momento sagrado, recuperando, para isso, de certa forma, o ambiente sonoro próprio do catimbó, como dissemos acima.

\section{VII}

Não sei porque os tetéus gritam tanto esta noite...

Não serão talvez nem mesmo os tetéus.

Porém minha alma está tão cheia de delírios

Que faz um susto enorme dentro do meu ser.

Estás imóvel.

És feito uma praia...

Talvez estejas dormindo, não sei.

Mas eu vibro cheinho de delírios,

\footnotetext{
${ }^{48}$ Ibidem, p 194-5.

${ }^{49}$ Vale lembrar que, entre os Iorubas, há também o Orixá-serpente Oxumarê, possuidor de dois sexos, representando, portanto, a união de opostos, de acordo com o Dicionário Aurélio.

${ }^{50}$ ELIADE, M. O sagrado e o profano. São Paulo: Martins Fontes, 1992, p 18-19.

${ }^{51}$ Ibidem, p 20.
} 
Os tetéus gritam tanto em meus ouvidos,

Acorda! ergue ao menos o braço dos seios!

Apaga o grito dos tetéus!

No movimento contínuo de encontros e afastamentos, o poeta e a negra continuam o jogo sensual que desenha o movimento da fuga, forma musical que retoma, na música tonal, estruturas míticas, como dissemos acima. O poema reconstrói as oposições defasadas que se imitam por meio da variação contínua próprias da fuga ${ }^{52}$, já que ora a negra, ora o poeta buscam realizar a sedução. No terceiro e no quarto poemas, a negra é o elemento ativo do par e procura possuir, por meio de seu beijo, o poeta. Já no quinto e no sexto poemas, o eu lírico, como que imitando o movimento anterior da negra, quer seduzi-la de forma ativa por meio de flores amarelas que a fecundam e por meio de sua mão-estrela que se alastra na escuridão da mulher. No sétimo poema, o poeta busca a conjugação, pois deseja fortemente a amada, mas espera dela o gesto que possa permitir a realização do desejo, só possível quando os dois se seduzem e se entregam ao mesmo tempo - "ergue ao menos o braço dos seios".

Novamente identificada com a terra - "és feito uma praia" -, a amada imóvel parece dormir com a mão sobre os seios, como as donas do Romantismo que, adormecidas, possibilitavam a realização sublimada do desejo interdito do eu lírico ${ }^{53}$. Se em Tempo da Maria, o poeta procurava, como os românticos, o amor sem sustos realizado por meio da imagem da mulher que dorme, acalentando o sono da amada - "durma sem medo, sossegada" -, nos Poemas da negra, possuído pelos delírios sexuais que fazem vibrar o seu corpo, traduzidos como gritos incessante de pássaros tetéus, o eu lírico implora para a amante que acorde e ao menos erga o braço dos seios, possibilitando a satisfação sexual que o livrará do fogo insuportável que o toma - "apaga o grito dos tetéus" - e da ânsia que antecede o gozo.

Como se fosse o grito agudo dos tetéus que cortam a noite, em contraste com a gravidade da negra - nota contínua que percorre os poemas - um desejo sexual intenso acomete o ser do eu lírico que, arrebatado pela loucura dos delírios, sente algo dentro de seu ser - sua alma - se assustar com o irromper repentino e extremo do auge do desejo sensual, causador de delírios - fuga da razão - e, portanto, elemento de acesso à essência primária das coisas $^{54}$. O outro nome dos tetéus - o onomatopaico "quero-quero" - exprime a vontade de

\footnotetext{
${ }^{52}$ WISINIK, J. M. O som e o sentido. São Paulo: Companhia das Letras, 2002, p 167.

${ }^{53}$ Mário de Andrade mostra, em Álvares de Azevedo, a sublimação do medo de amar por meio da imagem da mulher adormecida, provavelmente inspirada na Marion, de Musset, como dissemos no estudo do poema "Amar sem ser amado, ora pinhões!”.

54 “O tetéu é um camarada muito suspeito. No Amazonas há um longirrostro [pássaro com bico comprido] que não dorme. É o maguari [...] Passa a vida tentando dormir, colocando o bicão enorme sobre o lombo. Vai dorme-
} 
realização sexual que atinge, nesse poema, um dos seus ápices, momento que antecede o gozo $^{55}$.

\section{VIII}

Nega em teu ser primário a insistência das coisas,

Me livra do caminho.

Colho mancheias de meus olhares,

Meu pensamento assombra mundos novos,

E eu desejava estar contigo...

Há vida por demais neste silêncio nosso!

Eu próprio exalo fluidos leves

Que condensam-se em torno...

Me sinto fatigantemente eterno!

Ah, meu amor,

Não é minha amplidão que me desencaminha,

Mas a virtuosidade!

O ser primário da amada, profundamente identificado com a natureza, é capaz de arrebatar o poeta, tirando-o de suas preocupações do dia-a-dia e do seu caminho de intelectual. Admirar a negra, portanto, é o mesmo que contemplar o sublime apreendido por nós na natureza e desejá-lo é almejar aquilo que, de acordo com Kant, não pode ser possuído, pois está acima de qualquer medida ${ }^{56}$. Em Tempo da Maria, a mulher é sublime devido à distância que se estabelece entre o poeta e a dona desejada, invocando-o a uma transcendência. Nos Poemas da negra, em posição inversa, a amada não está nas alturas inatingíveis de uma santa, como Maria, mas ligada à força devastadora da natureza ${ }^{57}$. Se nos versos de 1926, o poeta admirava em segurança o sublime, evitando entregar-se a ele, nos

não-dorme, quando o bico escorrega, e o maguari desperta, gritando. O nosso tetéu é assim também. Põe uma patinha no meio da perna e fecha os olhos. A pata escapole e o tetéu acorda, badalando uma guizalhada" (CASCUDO, L. C. Dicionário do folclore brasileiro. São Paulo: Global, 2002, p 678).

${ }^{55}$ De acordo com Telê Ancona Lopes, inspirado pelo trabalho de Hercules Florence, estudioso da expressão oral dos animais, Mário de Andrade iniciou estudo sobre a Zoofonia, coletando em livros as menções feitas por escritores a vozes de animais, organizando-as em fichas. (De São Paulo: cinco crônicas de Mário de Andrade Organização, introdução e notas de Telê Ancona Lopez. São Paulo: editora Senac São Paulo, 2004, p 97). As onomatopéias povoam a fala de musicalidade, resgatando, principalmente quando vindas da imitação das vozes dos pássaros, a origem da música.

${ }^{56}$ KANT, I. Crítica da faculdade do juízo. Tradução de Valério Rohden e António Marques. Rio de Janeiro: Forense Universitária, 1993, p 96.

${ }^{57}$ Schopenhauer, retomando a nomenclatura kantiana, chama de sublime matemático aquele que se mostra por meio da grandeza incomensurável do objeto (forma similar a como o poeta vê a amada em Tempo da Maria) e de sublime dinâmico aquele que se revela por meio do poder ameaçador e incontrolável da natureza, podendo somente ser observado, no entanto, quando o sujeito consegue desviar a atenção dessa ameaça e contemplar o objeto (como nos Poemas da negra) (SCHOPENHAUER, A. Metafísica do Belo. Tradução apresentação e notas de Jair Barbosa. São Paulo: Editora UNESP, 2003, p 104). 
poemas de 1929, o eu lírico deseja abandonar o caminho seguro da racionalidade e se render às volúpias de uma outra realidade, desejando apreender, na experiência de conjugação com a natureza, o sagrado.

Como quem faz uma prece - "me livra do caminho" -, o eu lírico pede à negra que negue a "insistência das coisas" concebidas apenas por meio da razão, em favor da essência da vida que se mostra por meio de seu corpo primário. Mário de Andrade, ao querer unir-se sexualmente à negra, deseja possuir, portanto, a "Idéia" primeira das coisas. Apesar de suas "mancheias" de olhares e de pensamentos que "assombram mundos novos" frente à novidade do cotidiano diferente de seu país conhecido por meio da viagem ao Nordeste, o poeta deseja apreender não apenas aquilo que seu próprio pensamento racional pode revelar, mas a verdade que só pode ser compreendida por meio do silêncio - "Há vida por demais neste silêncio nosso!". Assim, os versos de 1929 revelam o eu lírico em busca da essência do mundo, tal como descrita por Schopenhauer, sendo a negra, portanto, não apenas a mulher desejada, mas também a alegoria do "outro", absorvente e desafiadora.

O filósofo alemão, aproximando o pensamento de Kant ao de Platão, parte das "Idéias" platônicas e da "coisa-em-si" kantiana para definir a realidade primeira das coisas - a "Vontade" -, não passível de ser apreendida por meio da ciência e do pensamento racional, sendo necessário, para tanto, abandonar os conceitos, as relações de causa e efeito e a noção de Tempo e Espaço, para que se possa, ao se transformar no "puro sujeito do conhecimento", apreender a Idéia que subjaz aos fenômenos, considerados, "pela maioria tola", como essenciais, sendo, na verdade, meras sombras refletidas na parede da caverna, como afirmara Platão ${ }^{58}$. De acordo com o estudioso, para ser capaz de conhecer o que está atrás dos fenômenos, é necessário ao sujeito que abandone a própria individualidade, se confundindo com o objeto, tal como faz o eu lírico, em Poemas da negra - "Não sou mais eu!" -, sendo capaz de apreender o que está além do revelado por seus olhos e pensamento, assumindo, ele próprio, características da natureza que, como o poeta, exala "fluidos leves/ que se condensam em torno..." e é "fatigantemente etern[a]", por meio de seus ciclos naturais de regeneração.

\footnotetext{
${ }^{58}$ Schopenhauer chama de "Vontade" o "em-si" tanto do sujeito, do objeto contemplado, como das Idéias (objeto mais próximo da Vontade, por estar livre do princípio da razão) - "Exterior a toda representação e a todas as suas formas nada existe senão precisamente a Vontade [...] Se suprimirmos o conhecimento, isto é, se suprimirmos o mundo como representação, em geral nada permanecerá senão a mera Vontade, ímpeto cego. Se essa Vontade se deve conhecer, isto é, alcançar objetividade, esta põe de um só golpe tanto o objeto quanto o sujeito. Se essa objetividade, por sua vez, deve ser inteiramente pura, perfeita, adequada à essência propriamente dita da Vontade, reproduzindo essa inteira essência como representação, então esse grau de objetivação põe de um só golpe o objeto como Idéia”. (SCHOPENHAUER, A. Op. cit., p 49)
} 
Pode ocorrer [...] que [...] nós deixemos de lado o modo comum de consideração das coisas, cessemos de seguir suas relações [...] pelo fio condutor do princípio de razão; então consideraremos não mais o onde, o quando, o por quê, o para quê das coisas, mas única e exclusivamente seu quê (ou seja, a Idéia). Também não é permitido que o pensamento abstrato - os conceitos da razão - tome conta da consciência, mas, em vez disso, toda a potência do espírito é devotada à intuição, afundando-nos completamente nesta [...] É uma maneira germânica de falar plena de sentido a de que nos perdemos por completo num objeto, ou seja, perdemos de vista justamente o próprio indivíduo [...] A disposição se torna puramente objetiva: toda a consciência é ainda apenas o espelho claro do objeto oferecido. ${ }^{59}$

Schopenhauer descreve o estado de conhecimento metafísico como "a intuição estética das coisas" ${ }^{60}$. O jogo sensual dos Poemas da negra, ao revelar o eu lírico propenso a se tornar puro sujeito do conhecimento e, portanto, capaz de apreender a Idéia que, de acordo com Schopenhauer, é o objeto da arte, fala também do processo artístico, aproximando-o do ato de sedução e de consumação sexual, revelando a arte que brota também da intuição e não apenas da "virtuosidade" técnica do artista.

A arte repete em suas obras as Idéias apreendidas por pura contemplação, o essencial e permanente de todos os fenômenos do mundo [...]. Sua única origem é o conhecimento da Idéia; seu único fim, a comunicação desse conhecimento [...]. A arte [...] retira o objeto de sua contemplação da torrente do curso do mundo e o isola diante de si; e esse particular, que era na torrente fugidia uma parte ínfima a desaparecer, torna-se um representante do todo ${ }^{61}$.

O gênio, de acordo com Schopenhauer, é o artista que consegue apreender de modo puramente intuitivo a essência das coisas e, além disso, ser capaz de reproduzi-la numa obra de arte planejada ${ }^{62}$. Essa questão nos lembra da preocupação de Mário de Andrade acerca da necessidade do equilíbrio entre técnica e inspiração. Nos Poemas da negra, o poeta possui o ser primário da negra, entregando-se como o sujeito que contempla intuitivamente a verdade das coisas, sem, nem por isso, negar a importância da técnica - da virtuosidade - que não o abandona, apesar de afirmar que o desencaminha.

Ao contrário da virtuosidade, a "amplidão" do poeta não o tira do caminho. Ser "trezentos e cinqüenta", como anunciara no poema de abertura de Remate de males, não

\footnotetext{
${ }^{59}$ SCHOPENHAUER, A. Op. cit., p 46.

${ }^{60}$ Ibidem, p 45.

${ }^{61}$ Ibidem, p 59.

${ }^{62}$ Vale lembrar que, para Schopenhauer, todos os homens possuem algum grau de genialidade, sendo, portanto, capazes de reconhecer o Belo e o Sublime nas artes e na natureza. Da mesma forma, há artistas que, mesmo não sendo gênios, são capazes de produzir obras consideráveis (SCHOPENHAUER, A. Op.cit., nota 42, p 83-4)
} 
impede sua entrega à contemplação da "Vontade", mas, antes, parece favorecê-la, já que esta requer a desindividualização do sujeito para ser apreendida. Dessa forma, o poeta que se multiplica, entregando-se continuamente à dispersão, pode sentir, por meio de sua entrega à negra, a essência das coisas.

\title{
IX
}

\author{
Na zona da mata o canavial novo \\ É um descanso verde que faz bem; \\ É uma suavidade pousar a vista \\ Na manteiga e no pelo dos ratos; \\ No mais matinal perfume francês \\ A gente domina uma dedicação; \\ Apertando os dedos no barro mole \\ Ele escorre e foge, \\ E o corpo estremece que é um prazer... \\ Mas você é grave sem comparação.
}

No nono poema, diversas imagens se sobrepõem polifonicamente, criando a sensação de simultaneidade, fazendo reverberar, como notas de um mesmo acorde, sentidos diferentes que, sobrepostos, recriam a paisagem dissonante. O verde da monocultura canavieira da zona da mata suscita o descanso e se sobrepõe à imagem do olhar que pousa sobre o estranho par que compõe a paisagem - manteiga e pelo de ratos. Ao lado da manteiga artesanal e dos animais rasteiros, o perfume europeu, delicado como a manhã, suscita desejos de declarações amorosas e, ainda compondo a sensação de simultaneidade, se sobrepõe à sensação prazerosa do corpo que estremece, sensualmente, ao sentir fugirem dos dedos o barro mole - a terra - do mangue, como se a lembrança do perfume das donas paulistas com traços europeus, como Maria, se juntasse ao deleite corporal dado pelas mulheres morenas como o mangue.

Ao falar da sensação prazerosa da mão que invade o barro fecundo do mangue, o eu lírico é levado a pensar na negra, identificada com a terra. Imagem destacada do acorde (da estrofe) dissonante formado pelas coisas insistentes que se amontoam polifonicamente, a negra é a nota grave sem comparação - a mais profunda, a mais pesada, a mais primária.

\section{$\mathrm{X}$}

Há o mutismo exaltado dos astros,

Um som redondo enorme que não pára mais.

Os duros vulcões ensangüentam a noite,

A gente se esquece no jogo das brisas,

A jurema perde as folhas derradeiras

Sobre Mestre Carlos que morreu.

Dir-se-ia que os ursos

Mexem na sombra do mato... 
A escureza cai sobre abelhas perdidas.

Um potro galopa.

Ponteia uma viola

De sertão.

Nós estamos de pé,

Nós nos enlaçamos,

Somos tão puros,

Tão verdadeiros...

Ô, meu amor!

O mangue vai refletir os corpos enlaçados!

Nossas mãos já partem no jogo das brisas,

Nossos lábios se cristalizam em sal!

Nós não somos mais nós!

Nós estamos de-pé!

Nós nos amamos!

$\mathrm{Na}$ primeira estrofe, o eu lírico, como se tivesse sua sensibilidade ampliada pelo momento sensual de conquista da amada, percebe o som insistente do silêncio dos astros - um "som redondo enorme", como a sonoridade do alaúde dedilhado pelo tupi ${ }^{63}$. Com a capacidade de sentir aflorada de quem está imerso na natureza - "a gente se esquece no jogo das brisas" -, o poeta, com sentidos mais apurados, apreende sons, sensações e imagens, compondo, por meio da aglutinação dos elementos invocados, o acorde de uma música singular. Assim, ao lado da imagem dos duros vulcões vermelhos que invadem o céu noturno, possuindo-o - a lava do vulcão eclode no céu -, é descrita a dispersão, na natureza, do poeta e da negra. Completando o quadro, a jurema perde suas últimas folhas sobre Mestre Carlos, o menino que morreu sob o juremal e renasceu nas sessões de catimbó ${ }^{64}$, assinalando o tema da morte e ressurreição que marca a conjugação sexual. Uma ao lado da outra, as imagens compõem o momento sagrado a que o poeta se entrega, em um abandono total de si mesmo.

\footnotetext{
63 "Outras vezes é um doente, um frio/ na minha alma doente como um longo som redondo... / Cantabona! Cantabona! / Dlorom!... / Sou um tupi tangendo um alaúde!" (ANDRADE, M. Poesias completas. Edição crítica de Diléa Zanotto Manfio. Belo Horizonte: Villa Rica, 1993, p 83).

${ }^{64}$ Em $O$ turista aprendiz, Mário de Andrade narra a história do menino que se tornou um dos mestres do catimbó após ter morrido ao desobedecer ao pai, abrindo uma sessão sozinho e incorporando uma entidade num mato de juremeiras, árvore usada para a produção de bebidas alucinógenas e afrodisíacas. (Cf. ANDRADE, M. O turista aprendiz. Estabelecimento de texto, introdução e notas de Telê Ancona Lopez. Belo Horizonte: Itatiaia, 2002, p 223 e CASCUDO, L. C. Dicionário do folclore brasileiro. São Paulo: Global, 2002, p 313). Mestre Carlos, "o 'que aprendeu sem se ensinar', [...] safadinho e brincador", tornou-se o protetor do poeta durante sessão de fechamento de corpo em um catimbó nordestino (ANDRADE, M. O turista aprendiz. Est. de texto, introdução e notas de Telê Ancona Lopez. Belo Horizonte: Itatiaia, 2002, p 224). O menino morto e renascido sob as folhas que se soltam da jurema é também um dos elementos formadores do brasão do poeta, no poema "Brasão" (1937), de A costela do grão cão ("E a jurema esfolhando as folhas derradeiras/ Sobre Mestre Carlos, o meu grande sinal").
} 
Compondo um ambiente onírico, a imagem de $\operatorname{ursos}^{65}$ que apalpam as sombras dos matos invoca a mesma sensação de ausência sentida pelo poeta ao tocar sombras de castas rainhas, no início dos Poemas da negra. Em um decrescendo, vão sendo enumerados o peso (leve) da escureza sustentada por abelhas, o galope do potro e a música que sai de uma viola do sertão, buscando o silêncio final da estrofe e criando um clima de enternecimento, ambiente propício para o momento de enlace amoroso.

$\mathrm{Na}$ segunda estrofe, os dois amantes são puros e verdadeiros, pois vivenciam o momento sagrado de atualização da hierogamia fundadora, em que os opostos se complementam. Ao deixarem de lado a própria individualidade, o poeta e a negra tornam-se apenas um, como em aquarela de Cícero Dias, de 1928, que retrata um casal em pé entregue ao abraço amoroso, por meio do qual seus corpos se confundem, formando um novo ser feito de misturas. ${ }^{66}$ A repetição insistente do pronome "nós", no início dos versos, assim como do possessivo "nosso(a)", reafirma a união, em um mesmo corpo, dos enamorados. Além da conjugação dos dois amantes, o corpo completo - yin e yang - se mistura também à natureza, já que o mangue os reflete, a brisa dispersa suas mãos e seus lábios se transformam em sal, como a água do mar ao ser secada pelo vento. A força da imagem dos lábios que adquirem a feição de cristais de sal recupera a sensação ímpar de secura do beijo dos amantes que, convertido em um dos elementos primários da natureza, fica pronto a ser espalhado pelos $\operatorname{ares}^{67}$. Antes, o poeta não era mais ele - "Não sou mais eu!" -, indicando a morte do boi sacrificial, agora, no momento que antecede o ato sexual, o corpo duplo dos amantes também se dissolve levado pelo vento - "Nós não somos mais nós!". Abandonando a individualidade, ambos se lançam ao contato mais profundo com a essência do mundo buscada avidamente pelo poeta. As imagens de conjugação e mistura, de esquecimento de si e desindividualização, que marcam o poema, sublimam, por um momento, as diferenças, inamovíveis, de fato, entre o poeta e a negra.

\footnotetext{
65 "Na figura do urso se baseia uma tradicional diversão carnavalesca da qual participam dois foliões: um deles é o urso, o outro o domador [...], o urso faz as estrepolias, vestido a caráter [...] Quando o urso é endinheirado, fazse acompanhar de sanfona, triângulo, bombo e reco-reco, animando o Carnaval do Recife". (CASCUDO, L. C. Op. cit., p 711).

${ }^{66}$ Anexo C (Cícero Dias: oito décadas de pintura. Projeto, curadoria e coordenação de Waldir Simões de Assis Filho. Curitiba: Museu Oscar Niemeyer, 2006, p 91)

${ }^{67} \mathrm{O}$ sal retirado das águas férteis do mar é item da tradição religiosa popular devido ao seu caráter ambiguamente purificador e destruidor. "No catimbó o sal é poderoso, indispensável para 'o trabalho às esquerdas', para o mal” (CASCUDO, L. C. Op. cit., p 612).
} 
Os corpos finos e compridos dos amantes ${ }^{68}$ tomam, no décimo poema, ao realizarem o enlace amoroso em pé, a forma de um mastro sagrado que, nas sociedades tradicionais, liga o céu e a terra, confirmando o caráter religioso da união do poeta e da negra, além de indicar a constituição de um espaço sagrado que possibilita ao poeta entrar em contato com o "real por excelência" ${ }^{69}$.

Temos, pois, de considerar uma seqüência de concepções religiosas e imagens cosmológicas que são solidárias e se articulam num "sistema" [...]: (a) um lugar sagrado constitui uma rotura na homogeneidade do espaço; $(b)$ essa rotura é simbolizada por uma "abertura", pela qual se torna possível a passagem de uma região cósmica a outra (do Céu à Terra e vice-versa) [...]; (c) a comunicação com o Céu é expressa indiferentemente por [...] imagens referentes todas elas ao Axis mundi [coluna universal]: pilar [...], escada [...] montanha, árvore, cipós etc; $(d)$ em torno desse eixo cósmico estende-se o "Mundo" [...], logo, o eixo encontra-se "ao meio", no "umbigo da Terra", é o Centro do Mundo ${ }^{70}$.

Quando finalmente se amam, o poeta e a negra experimentam a conjugação de opostos que, no desenvolver do poema - da fuga musical -, se buscaram e se escaparam, por inúmeras vezes, instaurando, assim, o momento supremo de ligação entre os dois pares da hierogamia inicial descrita por Hesíodo - o céu e a terra -, assim como dos dois temas musicais - o poeta e a negra -, possível apenas no momento em que ambos, entregues ao delírio amoroso, se buscam.

\section{XI}

Ai momentos de físico amor,

Ai reintrâncias de corpo...

Meus lábios são que nem destroços

Que o mar acalanta em sossego.

A luz do candieiro te aprova,

E... não sou eu, é a luz aninhada em teu corpo

Que ao som dos coqueiros do vento

Farfalha no ar os adjetivos.

Se, no Tempo da Maria, o poeta realiza a satisfação sexual de forma sublimada, escapando, assim, das asperezas da realidade em que o amor é interdito, nos Poemas da negra, sem medo de vivenciar o amor carnal, o eu lírico se entrega ao orgasmo físico,

\footnotetext{
68 "Nossos corpos são finos, / São muito compridos...".

${ }^{69}$ ELIADE, M. O sagrado e o profano. São Paulo: Martins Fontes, 1992, p 31.

${ }^{70}$ Ibidem, p 38.
} 
provando o gosto da essência primária que adivinhara na mulher, sentindo-o em si ao misturar seu corpo ao dela - "ai reintrâncias de corpo...". A ambígua interjeição "ai” - expressão de dor ou de alegria -, antes usada no poema "Cantiga do ai", de Tempo da Maria, para falar do sofrimento do amor impossível, aparece agora como expressão do gozo. Atingindo o momento do orgasmo em que, após a curva de excitação, chega-se ao desfazimento - morte -, o poeta sente seus lábios vagarem como destroços de seu ser que, dividido, como o boi das danças dramáticas, é acalentado pelo mar após o ímpeto da tempestade.

Ainda sentindo-se disperso pelo ambiente e vivenciando a calma que sobrevém ao orgasmo, o poeta, identificado com a luz tremulante do candeeiro - limite intangível da matéria -, sob o som do vento que faz farfalharem os coqueiros, se aninha no corpo negro da amante, formando, com ela, um só ser feito da mistura dos contrários primordiais - luz e escuridão -, separados, no Gênesis, durante a criação do mundo, realizando, portanto, um retorno à origem por meio da resolução da dualidade.

\section{XII}

Lembrança boa,

Carrego comigo tua mão.

O calor exausto

Oprime estas ruas

Que nem a tua boca pesada.

As igrejas oscilam

Por cima dos homens de branco,

$\mathrm{E}$ as sombras despencam inúteis

Das botinas, passo a passo.

O que me esconde

É o momento suave

Com que as casas velhas

São róseas, morenas,

$\mathrm{Na}$ beira do rio.

Dir-se-ia que há madressilvas

No cais antigo...

Me sinto suavíssimo de madressilvas

$\mathrm{Na}$ beira do rio.

Após o momento temido e desejado de conjugação de opostos que causa o despedaçamento do poeta - morte orgástica e mítica recuperada pela forma musical da fuga -, no último poema, o eu lírico se restaura em sua individualidade, atingindo o momento de anagnórisis, última parte do mito da procura, descrito por Northrop Frye, em Anatomia da crítica. 
Luta e dilaceramento chegam assim, num quarto momento, à anagnórisis, o reconhecimento, a readmissão das partes num corpo inteiriço, a volta triunfal dos fragmentos a uma totalidade renovada. Mais ainda, a anagnórisis é revelação: a identificação do corpo do homem com o corpo de um universo-deus, do sujeito de sua busca com a totalidade que o compreende ${ }^{71}$.

O poeta, não mais misturado com a negra, carrega, em seu ser, no entanto, a marca do toque da mão da mulher - "carrego comigo tua mão". Da mesma forma, mesmo não fazendo mais parte da natureza, sente a presença da paisagem que se impõe, de maneira marcante, sobre seu ser, ao andar pelas ruas de Recife. Como se estivesse a caminhar dentro de uma das aquarelas de Cícero Dias, o eu lírico descreve a maneira assimétrica e gigantesca com que as igrejas oscilam, como num sonho, sobre os homens, causando vertigens ${ }^{72}$. Além disso, ressalta a forma desmesurada com que o calor exausto pesa sobre as ruas que percorre - como o beijo da boca pesada da amante, cansada depois do momento de amor -, não deixando de destacar, ainda, a forma inútil com que as sombras, como seres animados, despencam das botinas que caminham sob o sol forte do dia.

Suscetível à maneira ostensiva com que a paisagem se impõe, o poeta, ainda sensível após a experiência de imersão no ser primário da amante, procurará se proteger da força das imagens que o rodeiam, por meio do momento suave do entardecer de Recife, bem descrito por Mário de Andrade, de acordo com Manuel Bandeira.

Nos "Poemas da negra" eu gosto muito da maneira por que o poeta tratou a Negra e o Recife [...]. O Recife está bem nestes versos em que há a calma das tardes no Capibaribe: "O que me esconde/ é o momento suave/ com que as casas velhas/ são róseas, morenas,/ na beira do rio." 73

O entardecer que tinge de rosa as casas ribeirinhas volta, novamente, a dar guarida ao poeta que, no entanto, não usa o momento vespertino para sublimar desejos, como em Tempo da Maria, mas para disfarçar a voluptuosidade que ainda o marca e que poderia tomá-lo, novamente, ao entrar em contato com o dia sensual pernambucano que se insinua como um beijo. Como o poeta de "Carnaval carioca", de Clã do jabuti, que procura, após ter vivenciado a explosão de sensualidade do carnaval do Rio de Janeiro, acalmar, ao fim da festa, "no país

\footnotetext{
${ }^{71}$ WISNIK, J. M. Dança dramática (Poesia/ música brasileira). Tese de doutoramento apresentada ao Departamento de Línguas Orientais e Teoria Literária. FFLCH - USP. São Paulo, 1979, p 73.

${ }^{72}$ Anexo D (Cícero Dias: oito décadas de pintura. Projeto, curadoria e coordenação de Waldir Simões de Assis Filho. Curitiba: Museu Oscar Niemeyer, 2006, p 25).

${ }^{73}$ BANDEIRA, M. Crônicas da província do Brasil. Organização, posfácio e notas: Júlio Castañon Guimarães. São Paulo: Cosac Naify, 2006, p 136-7.
} 
das lembranças/ a invasão furiosa das sensações", "[sentindo-se] mais seu [...] puro pelo contato de si mesmo" ${ }^{74}$, o eu lírico de Poemas da negra também busca, aos poucos, retomar a serenidade após a entrega desmedida ao ser primário da mulher.

As casas ribeirinhas, róseas e morenas ao pôr-do-sol, são transformadas pela imaginação do poeta em rosadas madressilvas - "dir-se-ia que há madressilvas no cais antigo" - que inundam, com seu perfume, a cena, envolvendo o eu lírico. As flores estrangeiras - originárias de climas temperados -, paradoxalmente imaginadas adornando o cais antigo e quente brasileiro, invocam, por meio da junção de contrários, o amor do poeta e da negra. No entanto, sob a proteção da Tarde e de suas cores róseas, a lembrança do amor se transforma em suave rememorar que acompanha o eu lírico como um perfume de flor. Se durante os Poemas da negra o poeta desejou possuir e se entregar à essência das coisas, no último poema, ao se recompor, renascendo, volta a sentir a paisagem como um elemento externo que, apesar de influenciar seu ser, não está profundamente ligado a ele, como nos momentos amorosos dos poemas do grupo.

Os silêncios e lacunas dos Poemas da negra, que dão a sensação de que algo se esconde por baixo dos versos, se revelando e, ao mesmo tempo, não se revelando, são a expressão da busca do poeta pela realidade primeira da vida que se esconde sob a roupagem dos fatos. Assim, ao intensificar o silêncio sob um lirismo recatado, ao molde dos ingleses, o poeta está aproximando sua poesia da verdade que está além das palavras, como lembra Octavio Paz, citado por Alfredo Bosi - "los objetos están más allás de lás palabras" 75 , falando, ao mesmo tempo, do impasse da poesia que, de acordo com o poeta, "es irreductible a la palabra y no obstante sólo la palabra la expresa" ${ }^{76}$.

\footnotetext{
${ }^{74}$ Versos do poema "Carnaval carioca" (1923).

${ }^{75}$ BOSI, A. O ser e o tempo da poesia. São Paulo: Companhia das Letras, 2000, p 38.

${ }^{76}$ Ibidem, p 38.
} 


\section{MOMENTOS AMOROSOS E MUSICAIS}

Ao lado dos grupos de poemas Danças (1924), Tempo da Maria (1926) e Poemas da negra (1929), dispostos, em Remate de males, nesta ordem, os doze poemas numerados de Poemas da amiga (1920-1930) fecham o volume de 1930, após a coletânea de textos Marco de viração.

O último grupo de Remate de males possui um tom comedido que lembra o tom contido de "Louvação da tarde", assim como as linhas suaves dos versos da negra, inscrevendo-se, dessa forma, na linhagem de poemas que, como diz Lafetá, parecem "terem sido escritos para a leitura em voz baixa" ${ }^{1}$, sobre os quais o estudioso discorre de forma interessante:

Penso mesmo que o Livro Azul [1941], mais os "Poemas da Negra" e os "Poemas
da Amiga" formam a melhor parte de uma das vertentes da poesia de Mário -
aquela que herdou do tom coloquial do Modernismo a visão "íntima" (não
"intimista") do homem e da vida brasileira, uma penetração doce e lenta no
interior das coisas, a percepção da possibilidade de conciliar os contrários, embora
mantendo sempre a tensão entre esperança e realidade. Uma linguagem
"abrandada" [...], recolhida, que parece voltar-se para a intimidade de um mundo
prestes a se dissolver em água, luz e sombra. ${ }^{2}$

Os Poemas da amiga recuperam ainda a ternura amorosa do poema bíblico "O cântico dos cânticos", como lembra Telê Porto Ancona Lopez ${ }^{3}$. De acordo com estudo de Geraldo Holanda Cavalcanti, o "Cântico" foi a obra literária que mais recebeu traduções e interpretações diferentes, sendo, ainda, o texto bíblico mais citado e discutido, além de ter inspirado inúmeros poemas e outras obras artísticas ${ }^{4}$.

Entre as inúmeras interpretações desse texto de quase três mil anos, o estudioso nos lembra das abordagens alegóricas que, realizadas incansavelmente por religiosos, a fim de justificar a inclusão de um canto de amor sensual nas escrituras sagradas $^{5}$, foram preponderantes até o final do século XIX. A partir do início do século XX, no entanto, novas propostas de interpretação surgiram, lançando luz sobre o "Cântico" que, de acordo com José Tolentino Mendonça, citado por Cavalcanti, é "a cartografia de um grande amor

\footnotetext{
${ }^{1}$ LAFETÁ, J. L. Figuração da intimidade. São Paulo: Martins Fontes, 1986, p162.

${ }^{2}$ Ibidem, p 163.

${ }^{3}$ LOPEZ, T. P. Mariodeandradeando. São Paulo: HUCITEC, 1996, p 102.

${ }^{4}$ CAVALCANTI, G. H. O cântico dos cânticos: um ensaio de interpretação através de suas traduções. São Paulo: EDUSP, 2005, p 13-15.

${ }^{5}$ Ibidem, p 21.
} 
desencontrado, da solidão que os amores muito grandes proporcionam [...]. A noite e o desejo, o corpo nomeado, perseguido, suplicado, o jardim entreaberto, a prece atendida" 6 .

A atribuição tradicional da autoria do poema ao rei Salomão é, de acordo com Cavalcanti, contestada atualmente, dividindo-se os estudiosos entre os que acreditam numa autoria singular do "Cântico" e aqueles que "o vêem como uma montagem anônima de diversos textos eruditos, ou mesmo populares, associados a festejos esponsalícios, ou, ainda, [...] uma coleção de cantos associados a ritos de fertilidade" 7 . Esta última interpretação permite aproximar "O cântico dos cânticos" ao caráter rapsódico das nossas Danças Dramáticas. Dessa forma, ao retomar o texto bíblico, Mário de Andrade se configura ainda como o rapsodo que organiza traços da tradição erudita e popular, ao elaborar seu canto.

Em Tempo da Maria, o poeta retoma a estrutura das Danças Dramáticas - cantigas, embaixadas, louvações - como matriz de seu fazer poético, recuperando a luta entre forças opostas, típica dos bailados populares, ao mostrar o embate entre o desejo do poeta pela mulher e a proibição de realizar o amor. Outro aspecto de nossas danças, a morte e a ressurreição, também é recuperado, já que o eu lírico, após sua dispersão no poema "Amar sem ser amado, ora pinhões!", realiza um esforço de reunificação em "Louvação da tarde".

Nos Poemas da negra, a forma do bailado não é recuperada explicitamente, como no grupo anterior, mas, após ter sido deglutida pelo poeta, transparece nos poemas. Nos versos de 1929, retomando o caráter tonal da fuga, dois temas - o poeta e a negra - se perseguem até a conjugação final, gozo que invoca, ao mesmo tempo, o momento de resolução tonal da música, assim como a etapa intensa do mito da busca em que o herói sofre o despedaçamento, seguido pelo momento de ressurreição em que procura se recompor.

Nos Poemas da amiga, assim como no conjunto de poemas de 1929, dois temas se perseguem mutuamente - o poeta e a amiga -, em uma fuga amorosa e musical, retomando, por meio do jogo sensual, aspectos das Danças Dramáticas que, como nos Poemas da negra, apenas se entremostram. No entanto, no último grupo de Remate de males, a luta sensual é mais amena e o desejo é sorvido com prazer, sendo mais importante do que a própria consumação sexual.

Dessa forma, como se fossem variações musicais sobre um mesmo tema, os três grupos partem da recuperação explícita da forma das Danças Dramáticas, nos poemas de

\footnotetext{
${ }^{6}$ Ibidem, p 21-2.

${ }^{7}$ Ibidem, p 23; 25.
} 
1926, e chegam até a maneira sutil de recuperá-la do grupo de 1930, em que a variação é intensificada e a forma inicial, portanto, bem diluída.

O jogo sensual delicado dos versos de 1930 aproxima os Poemas da amiga do “Cântico dos cânticos”, visto por Carey Walsh, entre outros estudiosos, como poesia erótica.

O Cântico diz respeito à questão provocativa de saber se a requintada sensação de desejar outrem poderia superar num sentido realístico o prazer da consumação sexual. A surpreendente pretensão de que pode parece ser a premissa do Cântico, que permanece focado na experiência do anseio, não na do alívio. [...] Esse aspecto do Cântico, o de que o desejo dos amantes nunca é satisfeito, é crucial, no entanto passa freqüentemente despercebido. [...] Os dois amantes se desejam [...] mas nunca se reúnem. Essa situação é frustrante e quase insuportável para o leitor que, ao cabo, espera ansioso uma trégua para a tensão ${ }^{8}$.

Como é mais valorizado do que a satisfação sexual, o desejo de união que percorre os poemas de 1930 é degustado de forma prazerosa e mais calma do que nos grupos anteriores. Além disso, os Poemas da amiga terminam sem que haja o momento de ressurreição, quebrando, dessa forma, tanto a curva sensual do desejo profano, como a forma circular das estruturas míticas e, ainda, o recomeço que sobrevém à resolução final da música tonal, aspectos que o poeta vinha retomando nos grupos de poemas anteriores. Os textos de 1930 são, portanto, um mito da procura sem renascimento do herói, uma fuga musical com um encontro final ambíguo e não resolutivo entre os dois temas e sem possibilidade de recomeço, assim como um orgasmo que não encontra um final.

Os Poemas da amiga não possuem a mesma idealização platônica dos versos de Tempo da Maria, em que o eu lírico busca a calma por meio de devaneios, nem o impulso sexual arrebatador de Poemas da negra, mas uma nova forma de amor a que se entrega o poeta, que busca uma conclusão, mas não a deseja tanto quanto a própria busca. Assim, os versos se constroem como o "Cântico dos cânticos", da forma como o vê Julia Kristeva, citada por Cavalcanti.

Conjugal, exclusivo, sensual, ciumento, sim, o amor do Cântico é tudo isso ao mesmo tempo, com ainda o inumerável da fusão carnal. Notemos que essas particularidades o distinguem radicalmente tanto dos amores platônicos, dos quais não tem nem o psicodrama nem a abstração ideal, como da mística patética e entusiasta dos amores orgíacos próprios dos cultos pagãos, com os quais não comparte a ilusão de plenitude. A distância igual dos dois, [...] o amor do Cântico inaugura uma nova página na experiência da subjetividade ocidental ${ }^{9}$.

\footnotetext{
${ }^{8}$ WALSH, C. E. Exquisite desire. In: CAVALCANTI, G. H. O cântico dos cânticos: um ensaio de interpretação através de suas traduções. São Paulo: EDUSP, 2005, p 77 (É bom lembrar que inúmeros outros interpretes acreditam que, no "Cântico dos cânticos", há a união sexual).

${ }^{9}$ KRISTEVA, J. Histores d'amour. In: Ibidem, p 42.
} 
Nos versos de 1930, não há o mesmo amor platônico de Tempo da Maria, nem o amor intenso e orgíaco de Poemas da negra, apesar de, de certa forma, estas características dos dois grupos aparecem unidas e apaziguadas no último conjunto de poemas, em que o poeta continua desejando uma mulher proibida, mas não da forma sofrida com que desejou Maria, nos poemas de 1926, assim como continua vivenciando a fuga amorosa, nos moldes do poema de 1929, mas de forma mais comedida.

Apesar de ter desejado com intensidade, nos Poemas da negra, o estado de "indiferença" que viu no seringueiro com maleita em sua viagem ao Norte do país, apenas no último grupo, o poeta o alcança, pois deixa de ansiar pelo repouso e começa a exercitar a “indiferença", a que irá, depois, conclamar o irmão pequeno, no Livro azul (1941), por meio da vivência da preguiça, um dos principais temas da obra de Mário de Andrade - "Vamos, irmão pequeno, entre palavras e deuses,/ Exercer a preguiça, com vagar”.

Dessa forma, o poeta estabelece um percurso que se inicia em Tempo da Maria e encontra certa solução nos Poemas da amiga. Como herói em busca do eu e do outro, o eu lírico percorre seus versos vivenciando dilemas que falam da essência da arte e, ao mesmo tempo, da vida. Para compreendermos a trajetória do poeta-viajante, é interessante recorrermos às idéias de Nietzsche ${ }^{10}$.

O filósofo alemão, preocupado em entender o nascimento da tragédia na civilização grega, discorre sobre os dois aspectos antagônicos que a compõem - o apolíneo e o dionisíaco $^{11}$-, aproximando-os às manifestações fisiológicas do sonho e da embriaguez ${ }^{12}$.

O sonho é a força artística que se projeta em imagem e produz o cenário das formas e figuras. Apolo é o nome grego para a faculdade de sonhar; é o princípio da luz, que faz surgir o mundo a partir do caos originário; é o princípio ordenador que, tendo domado as forças cegas da natureza, submete-as a uma regra [...]. Dá forma às coisas, delimitando-as com contornos precisos, fixando seu caráter distintivo e determinando, no conjunto, sua função, seu sentido individual [...]. Apolo é também o deus da serenidade, que, tendo superado o terror instintivo em face da vida, domina-a com um olhar lúcido e sereno ${ }^{13}$.

\footnotetext{
${ }^{10}$ Há exemplares de Nietzsche na biblioteca de Mário de Andrade (IEB).

${ }^{11}$ A imaginação figurativa apolínea produz, como lembra Rosa Maria Dias, "as artes da imagem, a escultura, a pintura e parte da poesia", e a potência emocional dionisíaca "encontra sua voz na linguagem musical" (DIAS, R. M. Nietzsche e a música. São Paulo: Discurso Editorial; Ijuí, RS: Editora UNIJUÍ, 2005, p 24).
}

${ }^{12}$ NIETZSCHE, F. O nascimento da tragédia. Tradução, notas e posfácio de J. Guinsburg. São Paulo: Companhia das Letras, 2007, p 24.

${ }^{13}$ DIAS, R. M. Op. cit., p 25. 
Em Tempo da Maria, após ter sido tentado pelos prazeres que o amor pela mulher proibida traria, o poeta luta para fugir à entrega à embriaguez dionisíaca, conseguindo, por meio de sonhos e devaneios, se reunificar, no final do grupo, restabelecendo-se como um ser individual, sereno e lúcido, identificado, portanto, com o aspecto apolíneo da tragédia - "Só no exílio/ de teu silêncio, [Tarde], os ritmos maquinares/ Sinto, metodizando, regulando/ O meu corpo. E talvez meu pensamento" 14.

Já nos Poemas da negra, há a união do poeta com as forças indomáveis da natureza, presentes no corpo sensual da mulher, e um abandono ao caráter dionisíaco do ato amoroso, sem deixar, todavia, de retornar, medrosamente, ao estado de individuação, no último poema do grupo. Nos versos de 1929, portanto, por meio do gozo sexual que instaura o êxtase, o poeta se identifica com o aspecto dionisíaco da tragédia.

A embriaguez é o estado que destrói, despedaça, abole o finito e o individual. Na embriaguez, desfazem-se os laços do principium individuationis, rasga-se o véu das ilusões para deixar aparecer uma realidade mais fundamental: a união do homem com a natureza. Sob o mundo das aparências [...] está o espaço de Dioniso - o nome grego para o êxtase. Dioniso é o deus do caos, da desmesura, da disformidade, da fúria sexual e do fluxo da vida; é o deus da fecundidade da terra e da noite criadora do som [...] Despertadas as emoções dionisíacas [...], o homem, em êxtase, sente que todas as barreiras entre ele e os outros homens estão rompidas, que todas as formas voltam a ser reabsorvidas pela unidade mais originária e fundamental - o "Uno primordial" 15 .

Apesar de, nos dois primeiros grupos, haver tanto aspectos dionisíacos como apolíneos, nos versos de 1926, o poeta está mais identificado com o estado de sonho - Apolo - e, nos Poemas da negra, mais próximo da embriaguez de Dioniso. Apenas nos Poemas da amiga, no entanto, os dois estados antagônicos se misturam e se reconciliam, aproximando, portanto, o último grupo, do estado ideal de arte encontrado na tragédia grega, configurandose como uma síntese dos dois grupos anteriores e, ao mesmo tempo, o seu contrário.

É preciso observar que, na Grécia dionisíaca, essa dilaceração do principium individuationis tornou-se pela primeira vez um fenômeno artístico. Há nos festivais greco-orgásticos uma ética diferente da dos bárbaros orgíacos. A diferença está na introdução do caráter apolíneo, ou seja, na "idealização da orgia" [...] Apolo impôs os laços da beleza ao deus poderoso, refreou o que havia de irracionalmente natural em Dioniso - a mistura da volúpia e da crueldade -, retirou-lhe das mãos as armas mortíferas, ao ensinar-lhe a medida ${ }^{16}$.

\footnotetext{
${ }^{14}$ Versos de "Louvação da tarde".

${ }^{15}$ DIAS, R. M. Op. cit., p 26.

${ }^{16}$ DIAS, R. M. Op. cit., p 30.
} 


\title{
Poemas da amiga
}

\author{
I
}

\begin{abstract}
A tarde se deitava nos meus olhos E a fuga da hora me entregava abril, Um sabor familiar de até-logo criava Um ar, e, não sei porquê, te percebi,

Voltei-me em flor. Mas era apenas tua lembrança. Estava longe, doce amiga; e só vi no perfil da cidade $\mathrm{O}$ arcanjo forte do arranhacéu cor-de-rosa Mexendo asas azuis dentro da tarde.
\end{abstract}

Após os prazeres noturnos de Poemas da negra, o poeta volta a vivenciar, como em Tempo da Maria, o crepúsculo que, identificado com o eu lírico, se deita em seus olhos. Sentindo em si o momento de intervalo e a leveza fugidia da tarde, que corre para a noite para a morte -, buscando o final de um ciclo, o poeta pode saborear o até-logo e perceber, por meio da rarefação do ar, a presença da amiga. O ventinho leve de Tempo da Maria, assim como o vento morno e denso de Poemas da Negra, ambos sinalizando a morte e dissolução do poeta, reaparece, nos poemas de 1930, mais rarefeito - é um ar, apenas.

Procurar pelo objeto de desejo e não o achar é ato recorrente em "O Cântico dos cânticos", marcado, como os Poemas da amiga, por encontros e desencontros dos amantes no tempo de amar - depois do inverno, no poema bíblico, abril, no poema modernista. Além disso, a identificação dos amantes a flores e a perfumes, no "Cântico", apontando o momento de fecundidade, também é retomada - "voltei-me em flor" - e, da mesma forma como o amor antigo dos dois amantes, a relação do poeta e da amiga é proibida e clandestina - o arcanjo poderoso sobre o arranha-céu vigia mexendo suas asas azuis.

O anjo sobre o edifício lembra a estátua sobre a catedral de Chartres, descrita no poema “L’Ange du Méridien”, de Rilke ${ }^{17}$. No entanto, se no poema de Rilke ${ }^{18}$, de acordo com Augusto de Campos, mesmo os seres efêmeros angelicais são contaminados por materialidade

\footnotetext{
${ }^{17}$ Nos Poemas da negra, por meio de versos silenciosos, em que falava um poeta invisível, a poesia se construía nos moldes dos versos do poeta alemão.

18 “anjo ridente, amável monumento,[...]

Não/ te ocorre vislumbrar por um momento

o quanto as nossas horas já se vão.

[...]

Pétreo, como saber das nossas penas?"
}

(CAMPOS, A. Coisas e anjos de Rilke. São Paulo: Perspectiva, 2007, p 23; 47). 
e "esculturados [...] em imagens concretas", nos versos do modernista, o anjo é uma "criatura evanescente" ${ }^{19}$.

Assim, mais do que se assemelhar à estátua de pedra do poema de Rilke, o anjo de ordem superior - o arcanjo - dos Poemas da amiga se aproxima do arcanjo descrito, nas "Elegias de Duíno", como "o perigoso", aquele que, se "surgisse agora das estrelas e/ desse um só passo em nossa direção, nosso próprio coração,/ batendo muito forte, nos abateria" 20. Aparecendo, de modo súbito, no perfil da cidade, no lugar em que o poeta procurava a amada, diluída na paisagem como lembrança, o arcanjo, ao vigiar, é como se fizesse o poeta responder à pergunta feita no início da segunda elegia de Rilke - "Quem sois vós?”:

Nosso sentimento é dispersão, ai de nós!

Exalamos nossa existência; [...]

o que é nosso nos foge, como o calor escapa de

um prato quente. [...]

O espaço cósmico, no qual nos dissolvemos, guarda ele o nosso gosto?[...]

Amantes, satisfeitos um com o outro, [...]

o vosso contato é abençoado pois ele dura; [...]

E quase vos prometeis a eternidade no abraço. Assim mesmo, ao suportar os pavores do primeiro olhar, a saudade à janela e o primeiro passeio juntos pelo jardim, amorosos; sois ainda os mesmos? Quando os vossos lábios se tocam e começais a beber, bebida a bebida oh, como foge então, estranhamente, o que bebe. ${ }^{21}$

A fugacidade e a diluição dos versos de 1930 são a resposta do poeta ao olhar inquisidor do arcanjo: somos seres cujo "sentimento é dispersão". Consciente, como o eu lírico da "Elegia de Duíno", de que os amantes ao se terem, se perdem, o poeta dos Poemas da amiga, mesmo assim, busca tomar a bebida que, ao ser sorvida, faz sumir "estranhamente, o que bebe" 22 .

\footnotetext{
${ }^{19}$ Ibidem, p 23.

${ }^{20}$ RILKE, R. M. Os sonetos a Orfeu e Elegias a Duíno. Tradução e seleção de Karlos Rischbieter e Paulo Garfunkel. Rio de janeiro: Record, 2002, p 135.

${ }^{21}$ Ibidem, p 135-139.

${ }^{22}$ O IEB guarda exemplar de Mário de Andrade das Poésie complétes de Rilke, no qual há, entre outros, poemas dos livros Elegias de Duíno e do livro Novos poemas.
} 
II

Si acaso a gente se beijasse uma vez só...

Ontem você estava tão linda

Que o meu corpo chegou.

Sei que era um riacho e duas horas de sede,

Me debrucei, não bebi.

Mas estou até agora desse jeito,

Olhando quatro ou cinco borboletas amarelas,

Dessas comuns, brincabrincando no ar.

Sinto um rumor.

"O cântico dos cânticos" é iniciado por versos sensuais que falam das delícias do ósculo - "Que ele me beije com os beijos da sua boca!/ Tuas carícias são mais saborosas que o vinho" 23 . De acordo com Cavalcanti, vários comentadores que interpretam o poema de forma alegórica acreditam que o beijo se refere à união do povo de Israel com Deus ou, ainda, à união da alma com a divindade. No entanto o estudioso afirma que o verso revela, já no início, a sensualidade que irá percorrer o cântico - "o beijo da boca é o beijo profundo, aquele que envolve as línguas dos amantes, donde a comparação imediata com o sabor do vinho",24.

O eu lírico do poema modernista deseja sorver, por meio da união com a mulher, o líquido que saciará sua sede, mas hesita e, apesar de debruçar-se sobre o riacho - a amada -, não bebe, ficando "desse jeito" - voltado para o elemento rarefeito, o ar, e para as borboletas amarelas. Se o poeta e a amada fossem levados, pelo acaso, a se beijarem, estariam unidos em um só ser, já que o beijo é o signo da unidade - a adesão de espírito a espírito ${ }^{25}$. No entanto, o eu lírico vivencia os prazeres da busca pela união, sem realizá-la, diluindo seu desejo após a rígida contenção.

Os Poemas da amiga são marcados por inúmeras imagens que remetem ao elemento rarefeito do ar. No segundo poema, abrindo mão das delícias sensuais da água, o poeta se satisfaz com a sutileza da imagem das borboletas brincando, no ar, como se desejasse, como elas, realizar o impulso sexual de forma sublimada - como uma dança no céu -, já que o verbo "brincar" tem grande conotação sexual, na obra de Mário de Andrade. Dessa forma, os poemas de 1930 buscam unir a satisfação amorosa com a sublimação dos desejos, juntando, portanto, os dois aspectos do "Cântico" - é um poema sensual e espiritual. O poeta está de tal

23 CAVALCANTI, G. H. Op. cit., p 229.

${ }^{24}$ Ibidem, p 249.

25CHEVALIER, J., GHEERBRANT, A. Dicionário de Símbolos. Rio de Janeiro: José Olympio, 2002, p 128. 
forma modificado, nesse grupo, que sua sensibilidade, aflorada ao extremo, permite que sinta nele mesmo, qual se fosse uma caixa de reverberação musical, o rumor das coisas do $\operatorname{ar}^{26}$.

III

Agora é abril, oh minha doce amiga,

Te reclinaste sobre mim, como a verdade,

Fui virar, fundeei o rosto no teu corpo.

Nos dominamos pondo tudo no lugar.

O céu voltou a ser por sobre a terra,

As laranjeiras ergueram-se todas de-pé

E nelas fizemos cantar um primeiro sabiá.

Mas a paisagem logo foi-se embora

Batendo a porta, escandalizadíssima.

Se, no primeiro poema, o eu lírico sentiu a presença da amada e, ao voltar-se, não a encontrou, como Orfeu, deslumbrando apenas a presença efêmera do arcanjo, no terceiro poema, é atraído pela verdade que se reclina sobre ele, como se sentisse, perto de si, a essência do mundo - a Vontade que mora por trás dos fenômenos. Indo em sua direção, no entanto, encontra o corpo desejado da amada. Assim, o acaso permite, sem aviso, a união efêmera dos amantes, causando um cataclismo que abala a ordem natural do mundo - o céu encontra a terra, em um casamento sagrado; o caos se instaura e se retorna ao tempo de antes da criação do mundo. Como em "O cântico dos cânticos", em que a união sexual não é afirmada explicitamente, mas sugerida por imagens que a ela remetem, o rosto do poeta, ao penetrar o corpo da amiga - seus seios -, alude ao ato sexual - "fundeei o rosto no teu corpo". No entanto, os dois conseguem dominar os impulsos dionisíacos, reorganizando, de forma apolínea, a paisagem, numa nova criação do mundo - "O céu voltou a ser por sobre a terra".

Diferente da oscilação entre o desejo e as proibições de Tempo da Maria, o balanço entre a entrega aos ímpetos amorosos e a decisão de dominar os impulsos sensuais não ocorre de forma abrupta e sofrida, como nos poemas de 1926, mas antes, como uma brincadeira reorganizam o mundo, como se fossem deuses, consertando o rebuliço que seus brinquedos

\footnotetext{
${ }^{26}$ No grupo Marco de viração, de Remate de males, um verso similar à última linha do segundo texto de Poemas da amiga aparece no poema "Momento", mostrando a sutileza de percepção do poeta que consegue captar algo a mais do que a observação racional permitiria - "Deve haver aqui perto uma roseira florindo,/ Não sei... sinto por mim uma harmonia".
} 
amorosos criaram, achando graça na dona Paisagem que, remexida, saiu batendo a porta escandalizadíssima com as liberdades dos amantes ${ }^{27}$.

\section{IV}

Ôh trágico fulgor das incompatibilidades humanas!

Que tara divina pesa em nosso corpo vitorioso

Não permitindo que jamais a plenitude satisfeita

Descanse em nosso lar como alguém que chegou!...

Não tenho esperanças mais nas vossas revelações!

Vós me destes o amor, me destes a amizade,

E na experiência de minha doce amiga me destes

Mais do que imaginei... Mas a volta foi cruel.

Eu sofro. Êh, liberdade, essência perigosa...

Espelhos, Pirineus, caiçaras e todos os desesperos,

Vinde a mim que outros agora aboiam pra eu marchar!

Tudo é suavíssimo na flora dos milagres...

Um pensamento se dissolve em mel e à porta

Do meu coração há sempre um mendigo moço esmolando...

Eu saí da aventura! Eu fugi da ventura!

Nós não estamos na cidade nem no mato.

Nós rolamos na ânsia dos fabulosos aeroplanos,

$\mathrm{E}$ vos garanto que agora não acabaremos mais!

Apesar de, no terceiro poema, a oscilação entre o desejo dionisíaco e a contenção apolínea acontecer de forma suave, sem os embates de Tempo da Maria, a transição para o quarto poema é feita de forma drástica. O tom ameno de brincadeira do texto anterior é cortado por versos longos, cadenciados e retóricos que formam, nos Poemas da amiga, a parte entoada em fortíssimo do cântico de Mário de Andrade. Irrompendo como trompetes avassaladores, a lamentação do poeta é altissonante, estendendo-se por versos marcados por pontos de exclamação.

Antes não anunciada, irrompe, no quarto poema, a indignação do poeta com o caráter trágico e intenso das relações humanas, marcadas, continuamente, por incompatibilidades

\footnotetext{
${ }^{27}$ De acordo com Cavalcanti, a amada do "Cântico" é chamada pelo amante de "amada minha", "minha pomba", "minha bela", "minha irmã", entre outras formas (Op. cit., p 274), sendo o amante tratado como amigo, uma única vez (Ibidem, p 237). Em algumas traduções da Bíblia, no entanto, a mulher é chamada de "amiga", pelo amante. Ao retomar este último termo, Mário de Andrade, além de estabelecer uma ligação com o "Cântico", mostra que a amada é amiga de brinquedos nos dois sentidos: companheira e amante. Além disso, a forma de tratamento nos faz lembrar da relação amistosa entre Mário e Tarsila do Amaral, amiga que, de acordo com Rubens Borba de Morais, citado por Silviano Santiago, "antes de casar-se com Oswald de Andrade, inspirou-lhe muitos poemas" (Carlos \& Mário: correspondência completa entre Carlos Drummond de Andrade e Mário de Andrade. Prefácio e notas de Silviano Santiago. Organização e pesquisa iconográfica de Lélia Coelho Frota. Rio de Janeiro: Bem-te-vi, 2002, p 163).
} 
proibitivas. A impossibilidade de harmonização entre os dois temas da fuga leva o poeta a levantar a voz contra a tara - o defeito, a degeneração, o peso -, paradoxalmente, divina, que impede a satisfação plena do corpo perfeito e vitorioso, criação de Deus que não deveria sucumbir a nada, deslocando, assim, a própria culpa para a fatalidade de ter sido criado dessa forma.

Apesar de reconhecer as delícias vividas ao lado da doce amiga - o amor e a experiência da amizade -, o poeta anuncia sua desilusão ao constatar que não poderá ter mais do que isso - "Não tenho esperança mais nas vossas revelações!" -, sofrendo terrivelmente. A dor dilacerante faz com que o eu lírico se identifique com o boi esquartejado das nossas Danças Dramáticas, vivenciando, dessa forma, as etapas de morte e despedaçamento dos bailados. Os "espelhos, Pirineus e caiçaras", harmonização de contrários do poema inicial de Remate de males - "Eu sou trezentos..." 28 -, em que o poeta também se identifica com o boi do Bumba, são invocados, nos Poemas da amiga, por meio de palavras de Jesus Cristo "vinde a mim" - aproximando, assim, o mestre das religiões cristãs - também morto e ressuscitado - ao rito de morte e ressurreição do boi das danças populares ${ }^{29}$.

Como diz Telê, o boi, além de ser "o poeta cindido, atado a seu destino, pagando à sua consciência o preço da dor", se converte, ainda, "no totem que deu origem à humanidade, a preguiça das explicações míticas indígenas, voltada para o gozo de cada instante" ${ }^{30}$. Em $O$ turista aprendiz, falando sobre a lenda do aparecimento do homem, contada pela tribo imaginária Do-Mi-Sol, Mário relata a briga, nos ramos de uma embaúva gigante, entre guaribas e preguiças - animais sagrados que se aproximam do boi, de acordo com a estudiosa. Como as preguiças ganharam a disputa, obrigaram os guaribas, ancestrais do homem branco, a andarem pelo chão, enquanto eles se mantiveram sobre a árvore, dando origem à tribo musical. Logo após, o turista descreve o caráter dos animais sagrados que ganharam o direito de permanecer sobre a árvore:

\footnotetext{
28 "Pirineus-alaúde ou a cultura do colonizador - ibérica e francesa - já deglutida, aguçando erudição e vanguardas. Caiçaras da permanência, isto é, os cercados que erguem e defendem o boi da voracidade das águas e das piranhas, em toda a Amazônia. Caiçaras que o Turista Aprendiz fotografa [...], construções típicas, produto do meio [...]; preservam o boi que, para Mário de Andrade, é o símbolo da unidade nacional” (LOPEZ, T. A. Mariodeandradeando. São Paulo: HUCITEC, 1996, p 101).

${ }^{29}$ De acordo com Mário de Andrade, a morte e a ressurreição da entidade principal do bailado, freqüente em nossas danças, vem de "uma noção mística primitiva, encontrável nos ritos do culto vegetal e animal das estações do ano, e que culmina sublimemente espiritualizada na morte e ressurreição do Deus dos cristãos" (ANDRADE, M. Danças dramáticas do Brasil. Edição organizada por Oneyda Alvarenga. Belo Horizonte: Itatiaia, 2002, p 33).
}

${ }^{30}$ LOPEZ, T. P. Op. cit., p 102 (grifo nosso). 
A verdade é que corre muito exagero a respeito da preguiça dos preguiças [...]. O que dá-se realmente entre esses animais sagrados é um conhecimento muito mais íntimo da vida e da relatividade da afobação. [...] Tinham adquirido aquele andar da sabedoria em que o pensamento reconhece que o que faz a felicidade não é o gozo dos prazeres do mundo, porém a consciência plena e integral do movimento. [...] Cada gesto que fazem [...] é feito com uma intensidade profunda, um ato em verticalidade, como agora se diz. É enfim o que [...] diríamos um gesto "gozado" [...]. De-certo os preguiças também já punham em prática uma doutrina dum grande filósofo da minha terra, Machado de Assis, que dizia que "também a dor tem suas volúpias" [...]. E é por basear toda a vida no princípio essencial da consciência do movimento que os preguiças são tão felizes. ${ }^{31}$

Consciente da beleza do movimento da busca, mais do que desejoso da realização sexual, o poeta pode atingir o estado de "indiferença" desejado, antes, nos Poemas da negra, dando-se conta, agora, de que é mais importante desfrutar a tentativa de conquista amorosa do que sorver a realização efêmera, entregando-se, como os animais sagrados, ao gozo de cada instante, inclusive ao gozo da dor do amor não correspondido, realizando o "milagre suavíssimo", possível após a invocação do próprio despedaçamento em espelhos, Pirineus e caiçaras. No poema "Rito do irmão pequeno", publicado em 1941, aparece o verso "A própria dor é uma felicidade", síntese, como afirma Telê, da "aceitação plena da condição humana [...] onde se esconde Epicuro e harmonia na coexistência vida/ morte", iniciada, como vimos, nos Poemas da amiga.

Se nos Poemas da negra, ao aproximarem-se do ato de consumação sexual, o envolvimento sensual arrebata os amantes que partem "nos turbilhões da estrela Vênus", nos poemas de 1930, o poeta e a amada deixam-se envolver pela "ânsia dos fabulosos aeroplanos", encontrando, no elemento aéreo, um outro lugar - um intervalo -, em que podem viver outro tipo de realização amorosa, em que não se entregam nem à volúpia, que marcou os poemas de 1929, nem à contenção racional de Tempo da Maria, em que o poeta fugira solitário dos embates do amor proibido, por meio de devaneios. Escapando do risco da realização de uma aventura amorosa, assim como de suas possíveis venturas, o poeta, ao lado de sua amada, deseja fugir da proibição das cidades - da civilização -, assim como da volúpia do mato - da natureza sem regras -, espaços freqüentados, alternadamente, pelos amantes de "O cântico dos cânticos" ${ }^{32}$, procurando, assim, o lugar em que o amor poderá perdurar.

\footnotetext{
${ }^{31}$ ANDRADE, M. O turista aprendiz. Estabelecimento de texto, introdução e notas de Telê Porto Ancona Lopez. Belo Horizonte: Itatiaia, 2002, p 144-5.

${ }^{32}$ No poema bíblico, a cidade cerca a relação dos amantes de proibições e riscos. O campo, no entanto, acolhe os dois como um leito de amor - "Nosso leito é um leito de folhas./ As vigas da nossa casa são os caules dos cedros/ e os lambris os ramos dos ciprestes" (CAVALCANTI, G. H. O cântico dos cânticos: um ensaio de interpretação através de suas traduções. São Paulo: EDUSP, 2005, p 230).
} 
Contam que lá nos fundos do Grão-Chaco

Mora o morubixaba chiguano Caiuari,

Nas terras dele nenhum branco não entrou.

São planos férteis que passam a noite dormindo

$\mathrm{Na}$ beira dum lagoão, calmo de garças.

Enorme gado pasta ali, o milho plumeja nos cerros,

E os homens são todos bons lá onde o branco não entrou.

Nós iremos parar nesses desertos...

Viajando através de fadiga e miséria,

Os dias ferozes nós descansaremos abraçados,

Mas pelas noites suaves nossos passos nos levarão até lá.

$\mathrm{E}$ ao vivermos nas terras do morubixaba Caiuari,

Tudo será em comum, trabucaremos como os outros e por todos,

Não haverá hora marcada pra comer nem pra dormir,

Passaremos as noites em dança, e na véspera das grandes bebedeiras

Nos pintaremos ricamente a riscos de urucum e picumã.

Pouco a pouco olvidaremos as palavras de roubo, de insulto e mentira,

A terminologia das nações e da política,

E dos nossos pensamentos afinal desertarão as profecias.

Oh, doce amiga, é certo que seríamos felizes

$\mathrm{Na}$ ausência deste calamitoso Brasil!...

Fecho os olhos... É pra não ver os gestos contagiosos...

Ando em verdades que deviam já não ser do tempo mais...

A nossa gente vai muito sofrer e tenho o coração inquieto.

Desejando partir em busca de um local que protegesse os enamorados dos riscos da aventura e, ao mesmo tempo, permitisse a realização do amor, o poeta, em um devaneio, imagina-se, ao lado da amada, nos desertos do morubixaba ${ }^{33}$ Caiuari, um espaço deslocado do mundo, interdito à civilização dos brancos. A "Pasárgada" de Mário fica nos "fundos do Grão-Chaco", local vislumbrado pelo turista aprendiz, de acordo com Telê, "ao cruzar, na Madeira-Mamoré, a fronteira Brasil-Bolívia” ${ }^{34}$. Mário de Andrade encontrou, como nos lembra a estudiosa, a figura do chiriguaiano Caiuari e a descrição de seu paraíso terrestre, em texto de Nordenskiold, publicado, em 1912, na Revue de Geographie Anuelle ${ }^{35}$.

No paraíso de Caiuari imaginado pelo poeta, os bens são comuns, o trabalho é dividido igualitariamente e os vocábulos "roubo, insulto e mentira", próprios da sociedade capitalista,

\footnotetext{
${ }^{33}$ Chefe temporal de tribos indígenas brasileiras.

${ }^{34}$ LOPEZ, T. P. Mariodeandradeando. São Paulo: HUCITEC, 1996, p 104. (cf. ANDRADE, M. O turista aprendiz. Estabelecimento de texto, introdução e notas de Telê Porto Ancona Lopez. Belo Horizonte: Itatiaia, 2002, p 134-6).

35 "Existe ainda nas solidões do Chaco um chefe chiriguaiano, Caiuari, numa aldeia onde nenhum branco jamais penetrou. Ela se encontra próxima de um grande lago; lá pastam os grandes rebanhos de cavalos e de vacas, e os celeiros estão sempre cheios" (tradução livre). (NORDENSKIOLD, E. La vie des indiens dans le Chaco (Amerique du Sud) In: LOPEZ, T. P. Mariodeandradeando. São Paulo: HUCITEC, 1996, p 114).
} 
são esquecidos em meio a danças e bebedeiras. Além disso, o lugar ermo, protegido de intervenções dos brancos, se assemelha ao Jardim das Delícias, invocado em vários momentos de "O cântico dos cânticos". Como lembra Cavalcanti, citando texto de Rose Marie Muraro, “o Jardim das Delícias é a lembrança arquetípica da antiga harmonia entre o ser humano e a natureza. Nas culturas de coleta não se trabalhava sistematicamente. Por isso os controles eram frouxos e podia se viver mais prazerosamente" ${ }^{36}$. De acordo com o estudioso, a partir do momento em que se domina as forças naturais e se instaura o trabalho sistemático, surgem controles rígidos contra a transgressão, por meio, principalmente, da repressão sexual e do prazer, elementos que favorecem o ócio, atrapalhando, portanto, a concentração durante o trabalho $^{37}$. O Grão-Chaco, com fertilidade abundante, repleto de água e alimentos, é o local em que se vive uma cultura de coleta, favorável, portanto, para a realização dos prazeres amorosos, interditos na civilização do poeta. Além disso, como lembra Cavalcanti, o Jardim das Delícias é visto, tanto pelas interpretações alegóricas como pelas leituras naturalistas do "Cântico", como a metáfora para o corpo da mulher ${ }^{38}$. Adentrá-lo, como deseja o poeta de Poemas da amiga, é, portanto, uma alusão à união sexual almejada.

Mário de Andrade, em texto de 1931, “A poesia em 1930”, lembra-nos como o verso de Manuel Bandeira, "Vou-me embora pra Pasárgada", sintetiza o estado de espírito de vários poetas, no final da década de 30 , desejosos de abandonar a vida cotidiana, marcada por turbulências políticas e revolucionárias ${ }^{39}$. Inserindo-se no rol de escritores que desejam, mesmo que transitoriamente, "dar de ombros", Mário de Andrade aponta seu poema "Danças" (1924), de Remate de males, como marcado pelo tema da partida. A mesma temática aparece em Poemas da amiga. No entanto, ao descrever o paraíso indígena - os costumes, as danças e a alegria dionisíaca -, o poeta aos poucos se lembra dos problemas da civilização que desejara abandonar e, por isso, como lembra Telê, "a culpa insinua-se na busca do lenitivo para a consciência exausta" 40 - "a nossa gente vai muito sofrer e tenho o coração inquieto".

Após ter oscilado entre o desejo de paganização, expresso pela atração que o poeta sente pelo território indígena, e a volta à civilização marcada pela religião católica, o eu lírico,

\footnotetext{
${ }^{36}$ MURARO, R. M. O martelo das feiticeiras. In: CAVALCANTI, G. H. Op. cit., p 212.

${ }^{37}$ CAVALCANTI, G. H. Op. cit., p 212.

${ }^{38}$ Ibidem, p 214

39 O país está a um passo da Revolução de 1930 que significará o fim da República Velha e da política Cafécom-Leite, levando Getúlio Vargas ao poder.

${ }^{40}$ LOPEZ, T. P. Mariodeandradeando. São Paulo: HUCITEC, 1996, p 104.
} 
no poema seguinte, volta-se à realidade urbana, passando a servir de exemplo aos operários da cidade.

\section{VI}

Nós íamos calados pela rua

E o calor dos rosais nos salientava tanto

Que um desejo de exemplo me inspirava,

E você me aceitou por entre os santos.

Erguer do chão um toco de cigarro,

Fumá-lo sem saber por que boca passou,

A terra me erriçava a língua e uma saliva seca

Pousando nos meus lábios molhados renasceu.

Todos os boitatás queimavam minha boca

Mas quando recomecei a olhar, ôh minha doce amiga,

Os operários passavam-se todos para o meu lado,

Todos com flores roubadas na abertura da camisa...

O Sol no poente, de novo auroral e nativo,

Fazia em caminho contrário um dia novo;

$\mathrm{E}$ as noites ficaram luminosamente diurnas,

E os dias massacrados se esconderam no covão duma noite sem fim.

Se antes desejara a ventura amorosa possível apenas "na ausência deste calamitoso Brasil”, no sexto poema, o poeta, ao lado da amiga, vivencia um amor mais amplo - o amor pelos brasileiros.

Ao caminhar pelas ruas, em silêncio, como se reverenciassem um ato sagrado prestes a irromper, os amantes são envolvidos pelo calor vindo das cores e do perfume estonteante dos "dez mil milhões de rosas paulistanas" ${ }^{41}$. O poeta, purificado, como santo, pela fogueira de flores, deseja servir de exemplo e abaixa-se de forma humilde para erguer do chão um toco de cigarro desprezado. Ao fumá-lo, "sem saber por que boca passou", o eu lírico sente a língua erriçada - arrepiada, hirta -, como que despertada sensualmente pela terra que pousa nela, e entrega-se à união com o representante anônimo do povo, por meio do beijo - pelo contato da umidade de seus lábios com a saliva seca do cigarro -, realizando a doação de vida ao indivíduo desconhecido e fazendo-o renascer, como se operasse um milagre. Além disso, o beijo úmido masculino fertiliza a terra do cigarro, reatualizando, portanto, a hierogamia inicial em que Uranos fertiliza Gaia ${ }^{42}$. Instaura-se, dessa forma, um momento sagrado em que os desejos de união, que marcaram os primeiros poemas, se expandem e se sacralizam.

\footnotetext{
${ }^{41}$ Verso de Paulicéia desvairada.

${ }^{42}$ Cf. ELIADE, M. Tratado de história das religiões. São Paulo: Martins Fontes, 1998, p 193.
} 
Se antes fugira do calamitoso Brasil, agora, o poeta se volta a ele, transformando-o por meio do ato exemplar. $\mathrm{O}$ fogo, símbolo de morte e ressurreição nos ritos iniciáticos, assim como da paixão sensual, instaura uma vida nova a partir do momento em que queima a língua do poeta, como inúmeros boitatás ${ }^{43}$, sacramentando o momento de união, tanto sexual como sagrada, da umidade da boca com a terra e com a saliva seca do cigarro. $\mathrm{O}$ ardor que cega momentaneamente o poeta, portanto, sinaliza o momento de purificação e renascimento que causa grandes mudanças no cenário urbano - os operários, sensuais, com flores na abertura da camisa $^{44}$, aderem ao ato revolucionário do poeta; o dia vira noite e a noite se transforma em dia, já que o sol, apesar de estar no poente, é auroral e caminha em sentido contrário ${ }^{45}$. O caos dionisíaco advindo de um ato santificado é aceito na civilização apolínea - o poeta e a amante, conscientes da necessidade de mudanças, não voltam a arrumar a paisagem, como fizeram no terceiro poema. Dessa forma, por meio do ato revolucionário sagrado, o poeta consegue se unir dionisiacamente aos outros homens, instituindo o caos benéfico, sem, no entanto, romper totalmente o estado apolíneo, já que sua revolução é apenas exemplar, alcançando, assim, o mesmo equilíbrio da tragédia grega, em que Apolo, de certa forma, dá a medida a Dioniso.

\section{VII}

É hora. Mas é tal em mim o vértice do dia

Nesta sombra... Porque serás mais que os rapazes,

E bem mais, muito mais do que as amantes?...

Sombra!... Sombra de cajazeira perfumada,

Saudando a minha inquietação com a tua delícia!

Eu poderia dormir no teu regaço, ôh mana...

Abri-vos, rincões do sossego,

Não cuideis que é minha amante, é minha irmã!

Porém é muito cedo ainda, e no portão do Paraíso

$\mathrm{O}$ anjo das cidades vigia com a espada de fogo na mão.

\footnotetext{
43 "Mboitatá protege os campos contra aqueles que os incendeiam; como a palavra o diz, Mboitatá é cobra-defogo" (CASCUDO, L. C. Dicionário do folclore brasileiro. São Paulo: Global, 2002, p 74), portanto, entidade protetora das matas, local em que se pode encontrar a vida prazerosa e mais completa do Jardim das delícias.
}

44 A sensualidade das camisas abertas é intensificada pela imagem das flores que, com suas hastes fálicas, aparecem nelas, fazendo-nos lembrar do episódio de Macunaíma, em que uma vendedora de flores coloca uma delas na lapela do herói, "botoeira" chamada, depois, por confusão, pela palavra "puíto", uma "bocagem" dita por Macunaíma (ANDRADE, M. Macunaíma. Belo Horizonte, Rio de Janeiro: Livraria Garnier, 2000, p 113115).

${ }^{45}$ No final do poema "Noturno de Belo Horizonte" (1924), de Clã do jabuti, a noite também se transforma em dia, em meio ao delírio do poeta, sinalizando "as núpcias miraculosas do dia e da noite", de que fala Genette (GENETTE, G. O dia; a noite. In: BARTHES, R. JAKOBSON, R. et al. Lingüística e Literatura. São Paulo: Martins Fontes, 1980, p 59-60), resultado da busca da união de contrários que permeia a obra de Mário de Andrade (Cf. SOUZA, C. R. Clã do jabuti: uma partitura de palavras. São Paulo: Annablume, 2006, p 197). 
VII (bis)

É uma pena, doce amiga,

Tudo o que pensas em mim.

Eu sei, porque acho uma pena

Também o que penso em ti.

Mesmo quando conversamos,

É uma pena, outras conversas

De olhos e de pensamentos,

Andam na sala, dispersas.

Assim como o dia é noite e a noite é dia, após a entrega sagrada do poeta, o ápice solar - o vértice - é claridade e, ao mesmo tempo, escuridão, embaixo da cajazeira. A sombra, vocábulo que, por meio de sua repetição insistente, tem sua sonoridade velada e pesada intensificada, despenca sobre o poeta, despejando sobre ele o seu contrário: o ponto mais alto do dia. Assim, como uma coluna universal mítica - Axis mundi -, o tronco esguio da cajazeira liga o céu e a terra, estabelecendo o local sagrado de ruptura e de união. O poeta, inserido nesse vértice, sente em si, ao mesmo tempo, a luz e a escuridão - a luz por meio da escuridão e a escuridão por meio da luz -, assim como o alto e o baixo e a terra e o céu, participando, portanto, da união dos contrários.

A cajazeira capaz de estabelecer a ligação do céu e da terra, numa união avassaladora, simboliza a amada, assim como a Sulamita - a amada do "Cântico" - é a palmeira alta desejada pelo amante.

Em todo o Cântico o jardim é o símbolo da Sulamita e da sua sexualidade. Ela é o jardim fechado (4:12), inacessível a qualquer pessoa, exceto ao amante que é convidado a nele penetrar (4:16), e apenas ele o faz (5:1). Ela é a fonte no jardim (4:15), a habitante do jardim (8:13), a vinha (1:6), a romãzeira (4:13), a palmeira (7:9). O amante pensa saboreá-la como a um cacho de uvas $(7: 13)$ e ela lhe promete o suco de suas romãs $(8: 2)^{46}$.

Assim como o amante da Sulamita é atraído pelo perfume dos frutos do jardim da amada - "Desperta, vento norte,/ chega-te vento sul,/ soprai sobre meu jardim/ e espalhai os seus perfumes. Venha o meu amado ao seu jardim/ e coma dos seus frutos saborosos (4:16)" 47 -, o poeta sente-se tentado pelo cheiro singular do fruto carnoso, mas azedo, da cajazeira freqüente na Amazônia brasileira -, delícia selvagem que instiga a inquietude sensual do poeta.

\footnotetext{
${ }^{46}$ CAVALCANTI, G. H. O cântico dos cânticos: um ensaio de interpretação através de suas traduçães. São Paulo: EDUSP, 2005, p 408.

${ }^{47}$ Ibidem, p 364.
} 
O eu lírico, no entanto, não deseja o gozo sexual, mas o descanso no colo - no regaço $^{48}$ - da mulher. Dessa forma, assim como o amante da Sulamita pede que ela lhe abra a porta de seu quarto, como podemos ver por meio do trecho do "Cântico dos cânticos" feito a seguir, o poeta implora para que sua amada o aceite, abrindo-lhe os "rincões" em que encontraria o sossego.

- "Eu dormia, mas meu coração vigilava.

Ouço a voz de meu amado, que bate:

- 'Abre-me! Minha irmã, minha amada”" [...]

- "Meu bem amado põe a mão pela fenda

e minhas entranhas estremecem.

Levanto-me para abrir-lhe a porta $[\ldots]$

Abri para meu amado,

Mas ele já se havia ido." 49

De acordo com Cavalcanti, alguns estudiosos vêem a tentativa do amante de abrir a porta da amada, colocando a mão pela fenda, como uma alusão a toques sensuais ${ }^{50}$, o que explicaria o estremecimento da Sulamita. O poeta modernista também procura "entrar" no corpo da mulher, desejando o lugar proibido e bem protegido - os rincões - da amada. No entanto, como se ela fosse uma irmã, o poeta deseja dormir em seu regaço, conseguindo, assim, um sono sensual e, ao mesmo tempo, livre de pecados, como aquele cantado no poema "Mãe", do livro A costela do Grã Cão (1941) ${ }^{51}$.

A amante do "Cântico" é chamada de irmã, forma de tratamento usada para se referir à mulher amada, no Oriente próximo. No final do poema bíblico, no entanto, a Sulamita usa o vocábulo "irmão", em contexto parecido com o dos Poemas da amiga - "quem me dera fosse meu irmão,/ [...] eu poderia te beijar em público/ sem que me censurassem" ${ }^{52}$. Querendo entregar-se sensualmente à amante, sem, no entanto, transgredir as normas sociais, o poeta

\footnotetext{
${ }^{48}$ Cavalcanti, ao comentar os versos "teu umbigo, uma taça torneada/ onde não falta o melhor vinho" (7:3), afirma que a palavra hebraica sar'rêch é traduzida por "umbigo" pela Vulgata e por "regaço" pela Neovulgata. Entre diferentes interpretações feitas por comentadores sobre o trecho do poema bíblico, o estudioso nos lembra daquela que acredita que a palavra designaria o baixo-ventre, "um eufemismo para designar a região pubiana, o sexo" (Ibidem, p 425-6).

${ }^{49}$ Ibidem, p 235-6.

${ }^{50}$ Ibidem, p 375.

51 “Ninguém como a mãe/ Pra agüentar a gente/ Escondendo a cara/ Entre os joelhos dela. [...] Só mesmo essa dona/ Que a-pesar-de ter/ A cara raivosa/ Do filho entre os seios,/ Marcando-lhe a carne,/ Sentindo-lhe os cheiros,/ Permanece virgem./ E o filho também" (ANDRADE, M. Poesias completas. Edição crítica de Diléa Zanotto Manfio. Belo Horizonte: Villa Rica, 1993, p 305-6).
}

${ }^{52}$ CAVAlCANTI, G. H. Idem, p 240. 
procura uma forma similar de realizar o desejo - "Não cuideis que é minha amante, é minha irmã!". No entanto, "é muito cedo ainda", e o anjo proibitivo e atento das cidades - da civilização - proíbe a entrada no Jardim das delícias - no paraíso perfumado da amada -, ostentando a espada de fogo que interdita o desejo e que protege a árvore da vida - a cajazeira -, arma já defrontada pelo poeta no primeiro poema de Tempo da Maria, ao marcar a viola de amor $^{53}$.

O sétimo poema é retomado, num bis, como peça musical aplaudida e repetida. No livro O losango cáqui (1926), Mário de Andrade havia utilizado o mesmo recurso ao refazer o poema XXXIII, em forma de soneto - "publicado na Klaxon o poema anterior causou hilariedade. Era natural. Por caçoada vesti minhas sensações e idéias com este soneto" ${ }^{54}$. Nos Poemas da amiga, as sensações expressas em forma livre no poema VII são revestidas por meio da forma popular de quadras em redondilha maior.

$\mathrm{Na}$ repetição do sétimo poema, os amados, assim como o ápice da luz se projeta no chão por meio da sombra da cajazeira, estão ligados um ao outro - a amiga pensa por meio do poeta e ele pensa por meio da amada ${ }^{55}$. Apesar de não estarem unidos de fato - "é uma pena" -, quando conversam, os olhos e pensamentos expressam a ligação profunda dos amantes, como se a alma de cada um deles, movida pelo pensamento do outro, soubesse, de forma não racional, coisas alheias.

Após o advento de uma nova realidade, instaurada pelo momento exemplar de união com o passante desconhecido, vivido pelo poeta-santo, no sexto poema, seguida pelo reconhecimento da união profunda dos amantes, no sétimo poema, os versos, mais calmos, passam a expressar, nos poemas seguintes, o prazer vindo da companhia mútua, abandonando, aos poucos, os dilemas anteriores e a queixa pela impossibilidade da relação, sem deixar, no entanto, de sugerir inquietações íntimas culposas.

Como Tempo da Maria, os Poemas da amiga são organizados, portanto, de forma simétrica: os seis poemas iniciais falam do desejo e da impossibilidade de realização amorosa, ainda marcados por tentativas de fuga, mas caminhando para a compreensão da possibilidade

\footnotetext{
${ }^{53}$ Cf. p 9 desta tese (“A viola de amor - Maria - possui duas aberturas simétricas para saída de som em forma de espada de fogo, lembrando a espada flamejante que aparece nas mãos do anjo que defende a árvore da vida, após a expulsão de Adão e Eva do paraíso (CHEVALIER, J., GHEERBRANT, A. Dicionário de Símbolos. Rio de Janeiro: José Olympio, 2002, p 393) , símbolo da razão que freia os impulsos instintivos”.)

${ }^{54}$ ANDRADE, M. Poesias completas. Edição crítica de Diléa Zanotto Manfio. Belo Horizonte: Villa Rica, 1993, p 146.

${ }^{55}$ Em "O cântico dos cânticos", os amantes também estão intimamente ligados - "Meu bem-amado é meu e eu sou dele" (2:16); "Eu sou de meu amado e meu amado é meu" (6:3) (CAVALCANTI, G. H. Op. cit., p 232 e 237).
} 
de uma união diferente e sublime, sinalizada pelo ato do poeta-santo. O poema VII, vértice da simetria, mostra a imagem da mistura de contrários, sugerindo a união dos amantes, apesar de ainda evocar o pesar pela proibição do amor. A partir do poema VII (bis), já do outro lado da simetria, os versos dos seis outros poemas iniciam um movimento oposto, caminhando em direção a outro tipo de satisfação sensual, em que a culpa, apesar de nunca abandonada, aparece de forma mais abrandada.

\section{VIII}

Gosto de estar a teu lado,

Sem brilho.

Tua presença é uma carne de peixe, De resistência mansa e um branco

Escoando azuis profundos.

Eu tenho liberdade em ti.

Anoiteço feito um bairro,

Sem brilho algum.

Estamos no interior duma asa

Que fechou.

$\mathrm{O}$ amor dos dois vai se realizando por meio de pequenos prazeres - olhos que se sabem, pensamentos que se unem, corpos que se sentem por meio da presença um do outro. Abandonando o brilho - a vivacidade e a expressividade -, o poeta se acalma ao lado da amiga que, de resistência mansa, como carne de peixe, impede a aproximação, até certo ponto, cedendo, depois. É preciso anoitecer, como um bairro afastado e escuro, para não embaciar o branco desvanecente que vem da presença da amiga e, entregando-se ao descanso e ao sono, poder deslumbrar seus azuis profundos.

O azul - a mais imaterial das cores, a transparência, o vazio tranqüilo do ar que acalma - nasce do branco, definido por Kandinsky como

o símbolo de um mundo onde todas as cores, em sua qualidade de propriedades de substâncias materiais, se tenham desvanecido... O branco produz sobre nossa alma o mesmo efeito do silêncio absoluto... Esse silêncio não está morto, pois transborda de possibilidades vivas... é um nada pleno de alegria juvenil, ou melhor, um nada anterior a todo nascimento, anterior a todo começo (CHEVAlIER, J., GHEERBRANT, A. Dicionário de Símbolos. Rio de Janeiro: José Olympio, 2002, p 142.)

A escuridão do poeta-noite e a rarefação da presença branca e azul da amada recolhem-se protegidos no interior da asa fechada, em que se pode vivenciar um outro tipo de 
amor, não mais composto pela busca por uma união carnal, mas por um abandono calmo às sensações $^{56}$.

A partir do vértice da simetria dos Poemas da amiga, se poderia pensar que, ao se consolar com a impossibilidade de união carnal, o amor do poeta estivesse se aproximando do amor cortês.

[No amor cortês], o amante [...] passa a servir ao amor, servindo à dama que o inspirou, sem nada mais desejar do que ser fiel a ambos, e sua recompensa está no mero reconhecimento de sua dedicação e fidelidade por parte da mulher amada. Se a amada e as circunstâncias consentem algo mais do que alguma troca de olhares, um toque de mãos já é mais do que pode aspirar o amante. A consumação física do amor não está excluída, mas é sublimada através da poesia, pois sua efetivação significaria, provavelmente, a tragédia e o fim do amor [...] (CAVALCANTI, G. H. Op. cit., p 202).

No entanto, o poeta modernista não assume, como em Tempo da Maria, a posição cortês do amante proibido. Nos Poemas da amiga, ao contrário, há um amor erótico, como o do "Cântico", mas refinado a ponto de ser realizado de forma diáfana, em um local deslocado que salva da culpa - o prazer advindo da presença da amiga e da união perfeita dos dois dentro de uma asa que se fechou.

Os versos suaves do oitavo poema, marcados pelo ritmo pausado, intensificam a sensação de calma e de sossego etéreo. O deslocamento da finalização das frases - "sem brilho", "Sem brilho algum" e "que fechou" -, criando versos novos, faz com que a melodia se estenda após o final das linhas, interrompida por uma suave pausa. Além disso, a seqüência de nasais - "De resistência mansa e um branco/ Escoando azuis profundos" - vai ampliando a sensação de sossego, na medida em que são reiteradas.

\section{IX}

Vossos olhos são um mate costumeiro.

Vossas mãos são conselhos que é indiferente seguir.

Gosto da vossa boca donde saem as palavras isoladas

Que jamais não ouvi.

Porém o que adoro sobretudo é vosso corpo

Que desnorteia a vida e poupa as restrições.

\footnotetext{
${ }^{56}$ Como no "Poema de sete faces", de Drummond, o azul está relacionado à ausência de desejos - "A tarde talvez fosse azul,/ não houvesse tantos desejos" (DRUMMOND, C. D. Alguma poesia. In: Sentimento do mundo. Rio de Janeiro: Record, 2001, p 11).
} 
Ôh, doce amiga! vossos castos espelhos de aurora

Despejam sobre mim paisagens e paisagens

Em que passeio feito um rei sem povo,

Cortejado por noruegas, caponetes e caminhos,

- Os caminhos incompetentes que jamais não me conduzirão a alguém!...

Mário de Andrade retoma um dos recursos usados em "O cântico dos cânticos", a saber, o uso de um gênero literário de origem árabe, conhecido como Wasf - "descrição" -, em que se exalta a beleza das partes do corpo da mulher, por meio de metáforas e imagens ${ }^{57}$. Assim como os olhos da amada do poema bíblico são escuros e misteriosos como as "piscinas de Hesebon" ${ }^{58}$, os olhos da mulher desejada dos poemas de 1930 são profundos e enigmáticos, da cor do chá-mate. Além dos olhos, o poeta louva as mãos da amada e o conselho dos gestos que apontam caminhos indiferentes, enaltecendo também sua boca, mais desejada pelas palavras de amor nunca ouvidas do que por sua delícia carnal ${ }^{59}$, mostrando-se desnorteado, sobretudo, pelo corpo sensual e arrebatador da mulher, comparável às curvas dos quadris, ao ventre e aos seios da Sulamita ${ }^{60}$.

Os olhos escuros da mulher, como lagoas espelhadas, refletem a luz branca da aurora e despejam, sobre o poeta, paisagens líquidas em que, como um rei sem povo, é cortejado por noruegas - vento frio e áspero -, por pequenos capões - porções de mato isoladas na paisagem - e por caminhos incompetentes que não sabem conduzir os homens, elementos que, renascidos no olhar da amada, fazem galanteios, ao cortejarem o eu lírico. Embevecido pelo mistério escuro dos olhos da amiga, que refletem a claridade branca do nascer do sol, o poeta se deixa envolver por sua cor líquida e aceita a união com a paisagem diluída neles, assim como, em Tempo da Maria, deixou-se "molhar" pelo cenário urbano, com ele se misturando - "E vem lavar minha retina,/ [...] Todas as coisas tamisando,/ O Tâmisa das ilusões./ Me dissolvo por essas águas!" 61.

Na segunda estrofe, após o vocativo - “ôh, doce amiga!” -, uma só frase se espraia por vários versos, demorando-se a se completar, contrastando, assim, com o ritmo pontuado da primeira estrofe, acentuando, dessa forma, a dor do eu lírico.

\footnotetext{
${ }^{57}$ CAVALCANTI, G. H. Op. cit., p 110.

58 "Hesebon era a cidade real dos amoritas [...], um lugar famoso por sua fertilidade e bem suprido de água. Perto havia dois reservatórios para abastecimento da cidade" (Ibidem, p 432).

${ }^{59} \mathrm{O}$ vocábulo midbarêch, no "Cântico", é traduzido tanto como "boca" quanto como "palavra" - "teus lábios, um traço escarlate, / e tua boca é graciosa" ou "tua fala é melodiosa" (Ibidem, p 341).

${ }^{60}$ Ibidem, p 239.

${ }^{61}$ Versos de "Amar sem ser amado, ora pinhões!".
} 
Os rios, ôh doce amiga, estes rios

Cheios de vistas, povoados de ingazeiras e morretes,

Pelo Capibaribe irás ter no Recife,

Pelo Tietê a São Paulo, no Potenji a Natal.

Pelo Tejo a Lisboa e pelo Sena a Paris...

Os rios, ôh minha doce amiga, na beira dos rios

É a terra de povoação em que as cidades se agacham

E de-noite, que nem feras de pelo brilhante, vão beber...

Pensa um bocado comigo na vasta briga da Terra,

E nas cidades que nem feras bebendo na praia dos rios!

Insiste ao pé de mim neste meu pensamento!

E os nossos corações, livres do orgulho,

Mais humilhados em cidadania,

Irão beber também junto das feras.

As cidades, como feras sedentas, acordam à noite para beber as águas dos rios, diferente das terras no morubixaba Caiuari que, plenas e satisfeitas, passam as noites dormindo ao lado do lagoão. A civilização que interdita o prazer, da qual o poeta tentara fugir, procurando o Jardim das delícias, possui também, em seu lado noturno, algo das feras da natureza. No escuro da noite, em que o inconsciente se alastra, momento do "acidente, [d]o desvio, [d]a alteração" ${ }^{62}$, de acordo com Genette, os rios, caminhos indicativos da localização da vida urbana, transformam-se no manancial que supre a sede do lado animal das cidades - a água purificadora, a fonte da vida.

O poeta conclama a amada a pensar com ele nos embates da civilização e, logo depois, no lado noturno que subsiste a eles. Pedindo que se ligue ao seu pensamento, o eu lírico invoca a companheira a participar do milagre - vivenciar, mesmo no espaço urbano, a vida plena entrevista nas terras do indígena Caiuari.

Os rios têm um papel importante na vida e na obra de Mário de Andrade, sempre atraído por seus mistérios e por seu potencial de revelação ${ }^{63}$, como podemos ver em trecho de O turista aprendiz.

Eu gosto desta solidão abundante do rio. Nada me agrada mais do que, sozinho, olhar o rio em pleno dia deserto. É extraordinário como tudo se enche de entes, de deuses, de seres indescritíveis por detrás, sobretudo se tenho no longe em frente uma volta do rio. [...] É fulminante. O rio vira de caminho no fim do estirão [...] e

\footnotetext{
${ }^{62}$ GENETTE, G. O dia; a noite. In: BARTHES, R. JAKOBSON, R. et al. Lingüística e Literatura. São Paulo: Martins Fontes, 1980, p 46.

${ }^{63}$ LOPEZ, T. P. Mariodeandradeando. São Paulo: HUCITEC, 1996, p 108.
} 
tudo se enche de mistérios vivos que se escondem lá atrás. A cada instante sinto que a revelação vai se dar, grandiosa, terrável, lá da volta do rio. ${ }^{64}$

Os mistérios, produtos do inconsciente, se revelam, ainda, à noite para o poeta em suas andanças pelas ruas de São Paulo.

Em São Paulo, nas minhas solidões procuradas de que eu gosto tanto, mas à noite pelas ruas dormidas, sempre tudo se enche em torno de mim, de gente, de seres. Mas então a realidade urbana impõe presenças mais utilitárias, são sempre ou personagens que eu invento pra ter casos pacíficos e felizes com eles, ou são meus companheiros de vida, meus amigos. Mas são sempre amigos melhores que os meus amigos de carne e osso. ${ }^{65}$

$\mathrm{O}$ rio, abundante de mistérios durante o dia, ao ser cercado pela noite, revela o momento em que a cidade, como um dos seres imaginados pelo poeta, se agacha e bebe de suas águas. A civilização, portanto, vive o momento pleno em que sacia os apetites sensuais, escondidos e interditos durante o dia. A descoberta desta outra vida urbana, possibilita ao poeta e à amada beberem "junto das feras", num ato contrário àquele praticado pelo eu lírico, no início dos Poemas da amiga, ao se debruçar sedento sobre o riacho - sobre a sensualidade da amada -, sem dele beber.

O poeta, portanto, ao mesmo tempo em que não quer abandonar o lado civilizado de seu ser, busca saborear também a sua parte primitiva, em sintonia com o estado de liberdade e felicidade de um Jardim das delícias. Como lembra Telê, Mário de Andrade "é um Camões debruçado sobre os rios que manam da alma [...], as 'altas torres' de seu ser convivendo com as pulsões turvas de que não pode e não quer se livrar, pois sabe que também sustentam seu arcabouço de artista e de brasileiro" 66.

\section{XI}

A febre tem um vigor suave de tristeza,

E os símbolos da tarde comparecem entre nós;

Não é preciso nem perdoar nem esquecer os crimes

Pra que venha este bem de sossegar na pouca luz.

\footnotetext{
${ }^{64}$ ANDRADE, M. O turista aprendiz. Estabelecimento de texto, introdução e notas de Telê Porto Ancona Lopez. Belo Horizonte: Itatiaia, 2002, p 73.

65 Ibidem, p 74.

${ }^{66}$ LOPEZ, T. P. Mariodeandradeando. São Paulo: HUCITEC, 1996, p 109.
} 
É a nossa intimidade. Um fogo arde, esquentando

Um rumor de exterior bem brando, muito brando,

E dá clarões duma consciência intermitente.

A poesia nasce.

Tu sentes que o meu fluido se aninha em teu colo e te beija na face,

E, por camaradagem, me olhas ironicamente.

Mas estamos sem mesmo a insistência dos nossos brinquedos.

E o vigor suave da febre

Não intimida os nossos corações tranqüilos.

A febre amorosa do poeta e da amiga, diferente dos amores arrebatadores e destruidores, é ao mesmo tempo intensa e suave como o estado indefinido de tristeza do crepúsculo que, indeciso entre a força do dia e o esmaecer das cores em direção à noite, se instala entre o poeta e a amada. Como se os dois amantes estivessem se entardecendo, cria-se, em torno deles, um ambiente de pouca luz e de sossego - é a tarde vasta, pálida, tardonha, filha doente de Sol já velho, capaz de criar o momento de pausa em que os ritmos se reorganizam e em que os devaneios se expandem, de "Louvação da tarde", que se instala na intimidade dos enamorados que, no entanto, não deixam de lado o vigor da paixão.

No ambiente acolhedor de pouca luz, espaço íntimo pertencente apenas aos dois amantes - um recanto protegido como o interior de uma asa que se fecha -, o fogo da febre esquenta os crimes e os rumores do homem urbano que ainda persistem no mundo exterior, fazendo com que se tornem brandos a ponto de poderem ser, não perdoados ou esquecidos, mas tolerados como murmúrios longínquos que ecoam no Jardim das delícias, forjado, pelos dois, em meio à vida agitada da civilização que não puderam abandonar.

Somente o fogo desse amor singular - que não faz o poeta fugir, como em Tempo da Maria, nem tampouco se entregar ao despedaçamento sensual dos Poemas da negra - pode criar uma consciência intermitente, oscilante entre a racionalidade e os fundos escuros do inconsciente, como os clarões de uma fogueira em um muro. Nesse estado, é possível o nascimento da poesia, já que ela é feita por meio da oscilação entre as soluções técnicas racionais e os impulsos descontrolados do lirismo - "Arte [...], somada a Lirismo, dá Poesia" 67.

O poeta, portanto, depois das hesitações entre a racionalidade e o amor, que marcaram os versos de 1926, e a entrega aos impulsos primitivos de seu ser, nos poemas de 1929, se reafirma, nos Poemas da amiga, como o trovador que, em Paulicéia desvairada (1922),

\footnotetext{
${ }^{67}$ ANDRADE, M. Prefácio interessantíssimo. In: Poesias completas. Edição crítica de Diléa Zanotto Manfio. Belo Horizonte: Villa Rica, 1993, p 63.
} 
sentia, "intermitentemente", em seu coração, o pulsar do primitivo que se esconde sob a civilização - "um tupi tangendo um alaúde" 68.

O momento em que a poesia nasce é também a hora em que algo gasoso e suave - o fluido do poeta - parte em busca da amada, dando-lhe um beijo na face, depois de ter-se aninhado em seu colo, revelando a união sensível e tranqüila entre os amantes que se beijam por meio de um movimento de alma. $\mathrm{O}$ ato sensual, ao contrário da exaltação física dos Poemas da negra, mantém os corações dos enamorados calmos, mesmo em face do ardor suave - da paixão.

\section{XII}

Minha cabeça pousa nos seus joelhos,

Vem o entre-sono, e é milagroso!

A vida se conserva em mim doada pelos seus joelhos,

E sou duma inimaginável liberdade!

Ôh espíritos do ar que os homens adivinham,

Dizei-me o que se evola do meu corpo!

Essa outra coisa vaporosa e brancacenta

Que não é fumo, nem echarpe,

Não tem forma porém não se desmancha

E baila no ar...

Todos os adeuses, todos os espelhos e girândolas

Voltijam no espaço que se enche e esvazia

Num tremor ávido a esfolhar-se em pregas sem dureza...

Abre a rosa oculta em sinais,

Manhãs em véspera de ser,

Pirineus sem desejo, enquanto à espreita,

Os objetos em torno me invejam

Buscando me prender na miséria da imagem...

Ôh espíritos do ar, dizei-me a rosa incomparável

Que se evola reagindo em baile no ar!

Baile! Baile de mim no entre-sono!

Não é uma alma, não é um espírito do ar, não é nada!

É outra coisa que baila, que baila,

Livre de mim! gratuita enfim! fútil de eternidade!

Oh, brinca, brinca, minha melodia!

Sabiá da mata que canta a mei-dia!

Olha o coco, Sinhá!

\footnotetext{
${ }^{68}$ ANDRADE, M. Poesias completas. Edição crítica de Diléa Zanotto Manfio. Belo Horizonte: Villa Rica, 1993, p 83.
} 
No momento em que o poeta pousa a cabeça nos joelhos da amada, como no poema "Mãe", de A costela do Grã Cão, acontece a união sensual e fraternal entre os dois amigos, imaginada no sétimo poema - "eu poderia dormir no teu regaço, ôh mana...". Assim, o desejo sensual se completa de forma branda, já que, no lugar do despedaçamento voluptuoso do gozo sexual - a morte -, há o entre-sono e a doação de vida da mulher para o amado, livres da vigilância do anjo das cidades, ao assumirem uma relação similar a de mãe e filho, como em La pietá.

O gozo acontece como um êxtase sagrado, vivenciado por meio da união mística e sensual dos dois. Assim como os crentes podem vivenciar o êxtase por meio da prece e do contado com Deus, o poeta entra em estado de delírio religioso ao repousar a cabeça nos joelhos da amada.

Que tais concomitâncias entre o êxtase e o orgasmo possam ocorrer não é estranho à análise que de suas experiências fizeram os próprios místicos, e de São Boaventura pode-se citar a referência àqueles que "in spiritualibus affectionibus carnalis fluxus liquore maculantur" ${ }^{69}$.

Teresa d'Ávila (1515-1582) também relata as emoções dos sentidos experimentadas por ela durante orações, mostrando a "concomitância entre ardores físicos e espirituais" 70, utilizando-se de passagens do "Cântico" para definir suas sensações - "fala de bebedeira divina e embriaguez celestial na adega do Senhor. Deus toca a parte mais íntima de seu ser [...] Teresa sente como se fosse desmaiar. Teresa está doente de amor" ${ }^{71}$.

Por meio do êxtase-gozo, o poeta atinge o estado de sobrelevação humana, desejado por ele, como confessa em carta a Manuel Bandeira.

Eu desejei mesmo um certo olimpismo, uma certa sobreelevação acima dos tumultos terrenos, desprezando o terra-a-terra... Deu no tom azul dos "Poemas da negra" e da amiga, no tom mais doirado do Girassol e quase branco do "Rito do irmão Pequeno" 72 .

Lafetá, citando Bachelar, discorre sobre "o azul que parece impalpável em toda a sua pureza [...] - o azul, espelho sem moldura, de uma transparência infinita, em que o mundo imaginado é posto antes do mundo representado, em que o conhecimento poético precede o

\footnotetext{
${ }^{69}$ CAVALCANTI, G. H. Op. cit., p 131.

${ }^{70}$ Ibidem, p 131.

${ }^{71}$ Ibidem, p 132.

72 ANDRADE, M. Cartas a Manuel Bandeira. In: LAFETÁ, J. L. Figuração da intimidade. São Paulo: Martins Fontes, 1986, p 165.
} 
conhecimento racional dos objetos" 73 , "fenomenalidade mínima" que Lafetá vê nos "Poemas da negra" e nos "Poemas da amiga" 74 .

Como dissemos anteriormente, há um percurso do poeta de Remate de males que, iniciando-se em Tempo da Maria, desemboca nos Poemas da amiga. Nesse trajeto, podemos observar uma rarefação da retomada da estrutura das Danças Dramáticas, das quais ainda se conserva, nos poemas de 1930, o caráter rapsódico e a morte simbólica do herói. Além disso, a curva do desejo sensual é feita de forma diferente, no último grupo, já que nele é exercido um prazer mais pleno, que não almeja a consumação sexual, estabelecendo-se como um exercício do estado de "indiferença", presente já nos Poemas da negra, tanto quanto uma aproximação gradativa da "fenomenalidade mínima" de que fala Lafetá.

Se nos versos de 1929, o poeta desejara, ao possuir o corpo "primário" da negra, chegar ao estado de pura contemplação das coisas e, livre das relações racionais, possuir a "Idéia" que se esconde por traz dos fenômenos, descrita por Schopenhauer, tornando-se, assim, capaz de intuir a essência do mundo, nos Poemas da amiga, o grupo mais "azul" de Remate de males, ao deixar de ansiar por uma consumação sexual e, por isso mesmo, abandonar o objetivo de entrever o estado primário das coisas, o poeta consegue atingir o estado de "indiferença", em que, como os "preguiças" da lenda indígena, pode desfrutar o prazer vindo de cada gesto, tornando-se, assim, o "puro sujeito do conhecimento" que espelha a essência das coisas. Ao sentir fluir de si algo brancacento e vaporoso que, rumo ao ar, baila esquecido da fenomenalidade dos objetos que o invejam, o poeta deixa, ele mesmo, as formas, transformando-se na Idéia pura de Schopenhauer, como Boi entregue a uma dissolução nunca imaginada.

No estado de torpor do entre-sono, oscilando entre a racionalidade da vigília e o mundo do inconsciente revelado em sonhos, a coisa sem forma, que se evola do poeta sem se desmanchar, encontra, no elemento rarefeito do ar, os espelhos e os Pirineus, agora, sem desejo, acompanhados pela voluptuosidade da girândola, roda que sustenta foguetes que estouram simultaneamente. Esses elementos esvoaçam em torno do poeta, num "tremor ávido", criando a intermitência de "pregas sem dureza". Tudo roda, numa dança diáfana, no espaço que "se enche e se esvazia". Como se o élan branco que se desprende do poeta fosse envolvido pelo bailado circular, passa a tomar a forma de uma roda - "a rosa oculta em

\footnotetext{
${ }^{73}$ LAFETÁ, J. L. Figuração da intimidade. São Paulo: Martins Fontes, 1986, p 166.

${ }^{74}$ Ibidem, p 167.
} 
sinais" -, lembrando a "rosa de Saron", invocada, em algumas traduções do "Cântico", para definir o amado - "eu sou a flor dos campos [a rosa de Saron],/ o lírio dos vales" 75.

Dessa forma, o poeta é transformado em rosa vaporosa após a "morte" encontrada no gozo não procurado, mas nascido suavemente por meio do gesto fraternal e filial do homem que apóia a cabeça nos joelhos da amada. Eliade afirma que a vida, "se acaso for interrompida bruscamente, por uma morte violenta, [...] procurará prolongar-se sob outra forma - planta, fruto, flor", citando os exemplos das roseiras que nascem do sangue derramado nos campos de batalha e das plantas nascidas do sangue e dos corpos de deuses mortos ${ }^{76}$. A morte sensual do eu lírico dos Poemas da amiga não é violenta e, por isso, a vida procura se conservar, não em rosas que florescem na terra, mas em uma rosa mística aérea. Por meio dela, o poeta experimenta uma outra vida em que, finalmente livre dos desejos, vivendo de forma desinteressada - gratuita -, como os preguiças, pode bailar infinitamente. Esquecido de renascer, o poeta se transforma na melodia que brinca, num gozo eterno, no final de suas Danças Dramáticas.

$\mathrm{Na}$ última estrofe, após retomar, com variações, os versos de uma louvação de despedida popular, comentada por Mário de Andrade, na coluna Mundo musical, da Folha da manha $\tilde{a}^{77}$ - "adonde ouvia cantar/ rouxinóis ao meio-dia" -, o poeta finaliza seu poema, assim como o livro Remate de males, com um refrão de "coco" marcado por um balanço sincopado - “- Olh' coc', Sinhá!” 78.

[O coco], dança popular de roda [...], disseminada pelo Nordeste, é acompanhad[o] de canto e percussão [...] O refrão é cantado em coro, que responde aos versos do "tirador de coco" ou "coqueiro". [...] É muito comum a roda de homens e mulheres com um solista no centro, cantando e fazendo passos figurados, que se despede convidando o substituto com uma umbigada ou batida de pé. ${ }^{79}$

Após o contato com a mulher, sentindo-se liberto dos dilemas eróticos para bailar em roda no espaço, livre de qualquer interesse, o poeta se entrega ao ritmo dançante do coco,

\footnotetext{
${ }^{75}$ Os intérpretes divergem sobre a atribuição dessa fala ao homem ou à mulher. Sharon é uma planície que se estende ao longo da costa. (CAVALCATI, G. H. Op. cit., p 285).

${ }^{76}$ ELIADE, M. Tratado de história das religiões. São Paulo: Martins Fontes, 1998, p 244.

${ }^{77}$ ANDRADE, M. Vida do cantador. Edição crítica de Raimunda de Brito Batista. Belo Horizonte; Rio de Janeiro: Villa Rica, 1993, p 79.

${ }^{78}$ ANDRADE, M. Os cocos. Preparação, ilustração e notas de Oneyda Alvarenga. São Paulo: Duas Cidades; Brasília: INL, Fundação Nacional Pró-Memória, 1984, p 162.

${ }^{79}$ ANDRADE, M. Dicionário musical brasileiro. Coordenação de Oneyda Alvarenga, 1982-84, e de Flávia Camargo Toni, 1984-89. Belo Horizonte: Itatiaia, 1999, p 146.
} 
marcado pelo "caráter de prazer desinteressado" ${ }^{80}$ da dança típica brasileira, como nos lembra Mário. A maneira com que os cocos são cantados, aproximando-se, em alguns momentos, da prosódia, mostram a grande liberdade dessa forma musical ${ }^{81}$, própria, portanto, para embalar os passos do poeta finalmente desamarrado dele mesmo.

Instigando, como solista, o coro a responder a seus versos, o poeta se entrega à dança do coco, buscando concluir a música dos poemas do livro de 1930, à maneira dos cantadores que tentam fechar os seus cantares, por meio de um "remate" final. No entanto, esse remate, na tradição popular, muitas vezes, não dá a sensação de acabamento definitivo da peça musical. Ao contrário, como nos esclarece Mário de Andrade, nos "cocos principalmente, [como] não terminam a melodia estrófica na tônica ou outro grau importante, a estrofe acaba numa tal instabilidade tonal que não se pode parar, começa-se outra" 82 .

Maurício de Carvalho Teixeira, em sua tese de doutorado, nos lembra da importância dada por Mário de Andrade à "terminação das melodias no grau sensível da escala, [...] uma importante característica da estética musical brasileira" ${ }^{83}$, transcrevendo, logo após, o manuscrito do poeta sobre esse tipo de terminação musical.

Não virá isso da precisão de continuar a peça infindavelmente como é muito do nosso gosto popular? É mais que provável que sim. A curiosa coincidência entre a encantação produzida pelas dinamogenias sonoras e a psicologia brasileira, é mais que coincidência. $\mathrm{O}$ cantador domina pelo efeito dinamogênico inerente ao som mais que pela boniteza da própria música. Vence por paciência e os ouvintes se deixam vencer por paciência. Certos cocos [...] repetidos 15 minutos em vez de engendrarem na gente o exaspero, a revolta contra a monotonia, é inconcebível o efeito delicioso de quentura amolecida [...] descanso eterno, paz infindável que dão. [...] E constato que a repetição da frase melódica é que convence. Daí a precisão de evitar na linha o efeito cadencial que termina duma vez. Daí a repugnância do brasileiro pela tônica. E daí a verdadeira atração pela sensível terminando o período e obrigando a iniciar outro que nos dê a esperança de $\operatorname{acabar}^{84}$.

Da mesma forma, o remate do livro de 1930 é uma finalização não conclusiva, envolvendo os leitores no estado de dança e gozo eternos a que o poeta, finalmente, depois de

\footnotetext{
${ }^{80}$ Ibidem, p 147.

${ }^{81}$ Ibidem, p 148.

${ }^{82}$ Ibidem, p 436.

${ }^{83}$ TEIXEIRA, M. C. Torneios melódicos: poesia cantada em Mário de Andrade. São Paulo, Departamento de Letras Clássicas e Vernáculas, Faculdade de Filosofia, Letras e Ciências Humanas, USP (Tese de Doutorado), 2007, p 29.

${ }^{84}$ ANDRADE, M. Manuscrito. In: TEIXEIRA, M. C. Op. cit., p 30.
} 
longo trajeto, conseguiu se entregar, no final dos Poemas da amiga, ao aceitar a própria diluição em dança ${ }^{85}$, sem necessidade de renascimento.

Oh, brinca, brinca, minha melodia!

Sabiá da mata que canta a mei-dia!

Olha o coco, Sinhá!

Como lembra Rosa Maria Dias, o homem, ao ser possuído por Dioniso, manifesta seu júbilo por meio de cantos e danças ${ }^{86}$.

Cantando e dançando, manifesta-se o homem como membro de uma comunidade superior: ele desaprendeu a andar e a falar, e está a ponto de, dançando, sair voando pelos ares [...]. Ele se sente deus, caminha tão extasiado e enlevado, como vira em sonhos os deuses caminharem. O homem não é mais artista, tornou-se a obra de arte. ${ }^{87}$

A terminação na sensível pode ser considerada, portanto, como lembra Maurício Teixeira, "o imponderável do dionisismo" ${ }^{88}$. No entanto, não podemos nos esquecer de que a entrega ao gozo eterno só pôde ser realizada pelo poeta de Remate de males, na medida em que o frêmito dionisíaco foi contrabalanceado por uma porção apolínea. O eu lírico sai voando pelos ares, mas, ao mesmo tempo, mantém-se seguro por meio da posição não condenável da cabeça no colo da amada-mãe-irmã.

\footnotetext{
85 “O poeta [...] se dissolve em dança” (LAFETÁ, J. L. Figuração da intimidade. São Paulo: Martins Fontes, 1986, p 168).

${ }^{86}$ DIAS, R. M. Nietzsche e a música. São Paulo: Discurso Editorial; Ijuí, RS: Editora UNIJUÍ, 2005, p 29.

${ }^{87}$ NIETZSCHE, F. O nascimento da tragédia. In: DIAS, R. M. Op. cit, p 29.

${ }^{88}$ TEIXEIRA, M. C. Op. cit., p 31.
} 


\section{Referência bibliográfica}

\section{Do autor:}

A música popular brasileira na vitrola de Mário de Andrade. Texto pesquisado e comentado por Flávia Camargo Toni. São Paulo: Editora Senac São Paulo, 2004.

ANDRADE, M. A dona ausente. Atlântico: revista luso-brasileira, Rio de Janeiro, n. 3, 1943. As melodias do boi e outras peças. Preparação, introdução e notas de Oneyda Alvarenga. São Paulo: Duas Cidades; Brasília: Instituto Nacional do Livro, 1987.

Amor e medo. In Aspectos da Literatura Brasileira. Editora Itatiaia: Belo Horizonte, 2002.

Aspectos da literatura brasileira. Belo Horizonte: Itatiaia, 2002a.

Aspectos da música brasileira. Belo Horizonte; Rio de Janeiro: Villa Rica, 1991.

Cartas a Manuel Bandeira. Rio de Janeiro: Edições de Ouro, 1967a.

Cartas de Mário de Andrade a Luis da Câmara Cascudo. Belo Horizonte-Rio de Janeiro: Itatiaia, 2000.

Cícero Dias e as danças do nordeste. Teresa: revista de Literatura Brasileira/ área de Literatura Brasileira. Departamento de Letras Clássicas e Vernáculas. FFLCH. USP - n. 1 (1º sem. 2000). São Paulo: Editora 34, 2000.

Contos novos. Belo Horizonte; Rio de Janeiro: Itatiaia, $1999 \mathrm{~b}$.

Danças Dramáticas do Brasil. Edição organizada por Oneyda Alvarenga. Belo Horizonte: Itatiaia, 2002.

Dicionário musical brasileiro. Coordenação de Oneyda Alvarenga, 1982-84, e de Flávia Camargo Toni, 1984-89. Belo Horizonte: Itatiaia, 1999.

Ensaio sobre a música brasileira. São Paulo: Livraria Martins, 1967b.

Introdução à estética musical. Pesquisa, estabelecimento de texto, introdução e notas por Flávia Camargo Toni. São Paulo: Hucitec, 1995.

Macunaíma. Belo Horizonte, Rio de Janeiro: Livraria Garnier, 2000.

Música de feitiçaria no Brasil. Belo Horizonte: Itatiaia; Brasília: INL, Fundação Nacional Pró-Memória, 1983.

Os cocos. Preparação, ilustração e notas de Oneyda Alvarenga. São Paulo: Duas Cidades; Brasília: INL, Fundação Nacional Pró-Memória, 1984.

$O$ turista aprendiz. Estabelecimento de texto, introdução e notas de Telê Porto Ancona Lopez. Belo Horizonte: Itatiaia, 2002b. 
ANDRADE, M. Pequena história da música. Belo Horizonte: Itatiaia, 2003.

Poesias completas. Edição crítica de Diléa Zanotto Manfio. Belo Horizonte: Villa Rica, 1993.

Vida do cantador. Edição crítica de Raimunda de Brito Batista. Belo Horizonte; Rio de Janeiro: Villa Rica, 1993.

Correspondência Mário de Andrade \& Manuel Bandeira . Organização, introdução e notas de Marcos Antonio de Moraes. São Paulo: EDUSP; IEB-USP, 2001.

Carlos \& Mário: correspondência completa entre Carlos Drummond de Andrade e Mário de Andrade. Prefácio e notas de Silviano Santiago. Organização e pesquisa iconográfica de Lélia Coelho Frota. Rio de Janeiro: Bem-te-vi, 2002.

De São Paulo: cinco crônicas de Mário de Andrade. Organização, introdução e notas de Telê Ancona Lopez. São Paulo: editora Senac São Paulo, 2004.

\section{Sobre o autor:}

BANDEIRA, M. Mário de Andrade. In: Crônicas da província do Brasil. Organização, posfácio e notas de Júlio Castañon Guimarães. São Paulo: Cosac Naify, 2006.

BASTIDE, R. Poetas do Brasil. São Paulo: Edusp; Duas Cidades, 1997.

CANDIDO, A. O poeta itinerante. In: _. O discurso e a cidade. São Paulo: Duas Cidades, 1993, p $257-278$.

CARVALHO, R. S. Edição genética d'O seqüestro da dona ausente de Mário de Andrade.

São Paulo, Departamento de Letras Clássicas e Vernáculas, Faculdade de Filosofia, Letras e Ciências Humanas, USP (Dissertação de Mestrado), 2001.

KNOLL, V. Paciente arlequinada. São Paulo: HUCITEC, 1983.

LAFETÁ, J.L. A dimensão da noite (Organização de Antonio Arnoni Prado). São Paulo: Duas Cidades; Editora 34, 2004.

Figuração da intimidade. São Paulo: Martins Fontes, 1986.

LOPEZ, T. P. A. A biblioteca de Mário de Andrade: seara e celeiro da criação. ZULAR, R. Criação em processo. Ensaios de crítica genética. São Paulo: Iluminuras, 2002.

Mário de Andrade: ramais e caminhos. São Paulo: Duas Cidades, 1972. Mariodeandradeando. São Paulo: Hucitec, 1996.

NITES, T. F. Leituras em francês de Mário de Andrade. São Paulo: Publicação do IEB, 1969. PROENÇA, M. C. Roteiro de Macunaíma. Rio de Janeiro: Civilização Brasileira; Brasília: INL, 1977. 
SOUZA, C. R. Clã do jabuti: uma partitura de palavras. São Paulo: Annablume; FAPESP, 2006.

SOUZA, G. M. O tupi e o alaúde. São Paulo: Duas Cidades, 1979.

TEIXEIRA, M. C. Torneios melódicos: poesia cantada em Mário de Andrade. São Paulo,

Departamento de Letras Clássicas e Vernáculas, Faculdade de Filosofia, Letras e Ciências Humanas, USP (Tese de Doutorado), 2007.

WISNIK, J. M. Dança dramática. (Poesia/ música brasileira). São Paulo, Departamento de Línguas Orientais e Teoria Literária, Faculdade de Filosofia, Letras e Ciências Humanas, USP (Tese de Doutorado), 1979.

Mário e a música. Revista da Biblioteca Mário de Andrade. São Paulo, v. 50, janeirodezembro de 1992.

O coro dos contrários: a música em torno da semana de 22. São Paulo: Duas

Cidades, 1983.

\section{Geral:}

ALIGUIERI, D. Da monarquia; Vida nova. Tradução de Jean Melville. São Paulo: Martin Claret, 2003.

ANCHIETA, J. Cartas, informações, fragmentos históricos e sermões do padre Joseph de Anchieta. Civilização Brasileira: Rio de Janeiro, 1933.

O Poema da Virgem. São Paulo: Edições Paulinas, 1958.

AZEVEDO, A. Lira dos vinte anos. In: Obra completa: volume único. Organização de Alexei Bueno. Rio de Janeiro: Nova Aguilar, 2000.

AZEVEDO, S. L. Dicionário de nomes de pessoas. Rio de Janeiro: Civilização Brasileira, 1993.

BENNETT, R.Uma breve história da música. Rio de Janeiro: Zahar, 1986.

BOSI, A. Céu, Inferno. São Paulo: Duas Cidades; Editora 34, 2003.

O ser e o tempo da poesia. São Paulo: Companhia das Letras, 2000, p 38.

CAMPOS, A. Coisas e anjos de Rilke. São Paulo: Perspectiva, 2007.

CANDIDO, A. O discurso e a cidade. São Paulo: Duas Cidades, 1993.

CARDOSO, S. O olhar viajante (do etnólogo). In: NOVAES, A. (org) O Olhar. São Paulo: Companhia das Letras, s/d.

CARPEAUX, O. M. História da Literatura Ocidental. Vol . IV - O Romantismo. Edições O Cruzeiro: Rio de Janeiro, 1962.

CASCUDO, L. C. Dicionário do folclore brasileiro. São Paulo: Global, 2002. 
CASCUDO, L. C. Meleagro. Rio de Janeiro: Agir, 1951.

CAVALCANTI, G. H. O cântico dos cânticos: um ensaio de interpretação através de suas traduções. São Paulo: EDUSP, 2005.

Cícero Dias: oito décadas de pintura. Projeto, curadoria e coordenação de Waldir Simões de Assis Filho. Curitiba: Museu Oscar Niemeyer, 2006.

CORSALETTI, F. Movediço. In: Estudos para seu corpo. São Paulo: Companhia das Letras, 2007.

CUNHA, C.; CINTRA, L. Nova gramática do português contemporâneo. Rio de Janeiro: Nova Fronteira, 1998.

CHEVAlIER, J., GHEERBRANT, A. Dicionário de Símbolos. Rio de Janeiro: José Olympio, 2002.

CORREA, R. A arte de pontear viola. Brasília; Curitiba: Editora Autor, 2000.

DIAS, R. M. Nietzsche e a música. São Paulo: Discurso Editorial; Ijuí, RS: Editora UNIJUÍ, 2005.

DRUMMOND, C. D. Alguma poesia. In: Sentimento do mundo. Rio de Janeiro: Record, 2001.

ELIADE, M. Tratado de história das religiões. São Paulo: Martins Fontes, 1998.

O sagrado e o profano. São Paulo: Martins Fontes, 1992.

FEUGÈRE, A. Un grand amour romantique. Paris: Boivin e Cie, Editeurs, 1927.

FREUD, S. Escritores criativos e devaneios. In: Obras psicológicas completas de Sigmund Freud. Rio de janeiro: Imago, 1967.

Três ensaios sobre a teoria da sexualidade. Pequena coleção das obras de Freud. Rio de Janeiro: Imago, 1973.

GENETTE, G. O dia; a noite. In: BARTHES, R. JAKOBSON, R. et al. Lingüística e Literatura. São Paulo: Martins Fontes, 1980.

GUIMARÃES, R. Dicionário da mitologia grega. São Paulo: Cultrix, 1995.

HEGEL, G. W. F. Cursos de estética. Vol. II. Tradução de Marco Aurélio Werle, Olivier Tolle. São Paulo: EDUSP, 2000.

IANNI, O. Enigmas da modernidade. Rio de janeiro: Civilização Brasileira, 2000.

JOHNSON, S. The Norton Anthology of English Literature, $5^{\text {th }}$ edition, 1962.

KANT, I. Crítica da faculdade do juízo. Tradução de Valério Rohden e António Marques.

Rio de Janeiro: Forense Universitária, 1993.

KAROLYI, O. Introdução à música. São Paulo: Martins Fontes, 1990. 
KIEFER, B. Villa-Lobos e o modernismo na música brasileira. Porto Alegre: Movimento; Brasília: INL/ Fundação Nacional Pró-Memória, 1986.

KOCH-GRÜNBERG, T. Do Roraima ao Orinoco, v. 1: observações de uma viagem pelo norte do Brasil e pela Venezuela durante os anos de 1911 a 1913. Tradução de Cristina Alberts-Franco. São Paulo: Editora UNESP, 2006.

LÉVI-STRAUSS, C. Mito e música. In: Mito e significado. Lisboa: Edições 70, 2000.

MIELIETINSKI, E. M. A poética do mito. Rio de Janeiro: Forense, 1987.

NIETZSCHE, F. O nascimento da tragédia. Tradução, notas e posfácio de J. Guinsburg. São Paulo: Companhia das Letras, 2007.

NOBRE, A. Só. Publicações Europa-Améria. s/l, s/d.

PAZ, O. O arco e a lira. Trad. Olga Savary. Rio de Janeiro: Nova Fronteira, 1982.

RAMOS, A. Notas de etimologia. Bahia: Escola de Aprendizes Artífices, 1932.

RILKE, R. M. Jardins. Tradução de Fernando Santoro. Rio de Janeiro: Sette Letras, 1995. Os sonetos a Orfeu e Elegias a Duíno. Tradução e seleção de Karlos Rischbieter e Paulo Garfunkel. Rio de janeiro: Record, 2002.

ROMERO, S. Cantos populares do Brasil. Rio de janeiro: Livraria Francisco Alves, 1897.

RONCARI, L. O Brasil de Rosa: mito e história no universo rosiano. São Paulo: Editora UNESP, 2004.

ROQUETTE-PINTO, E. Rondônia. 6.ed. São Paulo: Editora Nacional; Brasília: INL, 1975.

ROSEN, C. A geração romântica. Tradução de Eduardo Seincman. São Paulo: EDUSP, 2000.

SADIE, S. The new grove dictionary of musical instruments. [S.1.]: Macmillian, [1984?].

SHELLEY, P. B. The complete poetical Works of Percy Bysshe Shelley. London: Humphrey

Milford, Oxford University Press, 1917.

SCHOPENHAUER, A. Metafísica do Belo. Tradução apresentação e notas de Jair Barbosa. São Paulo: Editora UNESP, 2003.

Teresa: revista de Literatura Brasileira. Departamento de Letras Clássicas e Vernáculas. Faculdade de Filosofia, Letras e Ciências Humanas, Universidade de São Paulo. São Paulo: Editora 34, n. 1, 2000.

WISNIK, J. M. Machado maxixe: o caso Pestana. Teresa: revista de Literatura Brasileira, Departamento de Letras Clássicas e Vernáculas. Faculdade de Filosofia, Letras e Ciências Humanas. Universidade de São Paulo. São Paulo: Editora 34, n. 4/ 5, 2003. O som e o sentido. São Paulo: Companhia das Letras, 2002. 